Pamela Elizabeth Velarde Loayza

Estudo da eficiência de polímeros naturais (quitosana e ácido húmico) na floculação e desaguamento de polpas minerais

Dissertação de Mestrado

Dissertação apresentada como requisito parcial para obtenção do grau de Mestre pelo Programa de PósGraduação em Engenharia de Materiais e de Processos Químicos e Metalúrgicos da PUC - Rio.

Orientador: Prof. Eduardo de Albuquerque Brocchi Co-orientadora: Profa. Silvia Cristina Alves França 
PAMELA ELIZABETH VELARDE LOAYZA

\section{Estudo da eficiência de polímeros naturais (quitosana e ácido húmico) na floculação e desaguamento de polpas minerais}

Dissertação apresentada como requisito parcial para obtenção do grau de Mestre pelo Programa de PósGraduação em Engenharia de Materiais e de Processos Químicos e Metalúrgicos do Departamento de Engenharia Química e de Materiais do Centro Técnico Científico da PUC-Rio. Aprovada pela Comissão Examinadora abaixo assinada.

Prof. Eduardo de Albuquerque Brocchi

Orientador e Presidente Departamento de Engenharia Química e de Materiais - PUC Rio

Profa. Silvia Cristina Alves França Co-orientadora Centro de Tecnologia Mineral - CTM

Prof. Roberto José de Carvalho Departamento de Engenharia Química e de Materiais - PUC Rio

Profa. Helen Conceição Ferraz Universidade Federal do Rio de Janeiro - UFRJ

Prof. José Eugenio Leal Coordenador Setorial de Pós-Graduação do centro Técnico Científico da PUC-Rio 
Todos os direitos reservados. É proibida a reprodução total ou parcial do trabalho sem autorização da universidade, da autora e do orientador.

\section{Pamela Elizabeth Velarde Loayza}

Graduou-se em Engenharia Química pela Universidad Nacional de San Agustín - Perú em 2004.

Ficha Catalográfica

Estudo da eficiência de polímeros naturais (quitosana e ácido húmico) na floculação e desaguamento de polpas minerais / Pamela Elizabeth Velarde Loayza ; orientador: Eduardo de Albuquerque Brocchi ; co-orientadora: Silvia Cristina Alves França. - 2015.

172 f. : il. color. ; $30 \mathrm{~cm}$

Dissertação (mestrado)-Pontifícia Universidade Católica do Rio de Janeiro, Departamento de Engenharia Química e de Materiais, 2015.

Inclui bibliografia

1. Engenharia Química - Teses. 2. Engenharia de materiais - Teses. 3. Floculação. 4. Partículas finas. 5. Colóides. 6. Ácido húmico. 7. Quitosana. I. Brocchi, Eduardo de Albuquerque. II. França, Silvia Cristina Alves. III. Pontifícia Universidade Católica do Rio de Janeiro. Departamento de Engenharia Química e de Materiais. IV. Título. 
A Deus por ser minha guia, protetor e o exemplo mais grande de amor. Por ficar do meu lado o tempo todo e não me deixar desmair nos tempos de fraqueça.

A meu amado esposo Paúl, por ter-me dado coragem, paciencia, compreensão e muita força para a realização deste logro, obrigada por fazer cada dia os mais lindos de mi vida.

A meus pais Julio César e Carmen por seu grande apoio, amor e sacrificios em todos estes anos, quero agradecer em ajudarme a ser o que sou. Tem sido um privilegio ser sua filha. São os melhores pais.

Aos meus irmãos Julio César e César Augusto, por me ensinar a lutar, por me mostrar o lado bom de tudo, e pelo grande carinho que compartilhamos dia a dia.

A meu tío Miguel Loayza, por ficar sempre comigo e por colocar em mim muito espíritu de luta e perseverança com muito carinho. 


\section{Agradecimentos}

Agradeço a Deus por me iluminar e me dar forças sobre todo nos dias mais difíceis.

Agradeço ao meu orientador Professor. Eduardo Brocchi pelo apoio e confiança depositada, e aos professores do Departamento de Engenharia Química e de Materiais da PUC-Rio.

A minha co-orientadora Professora Silvia França; pela paciência, ajuda, motivação, amizade, e por ter compartilhado seus conhecimentos para o desenvolvimento de minha dissertação.

À professora Helen Ferraz da COPPE, por me ajudar com a realização dos testes de potencial zeta e por ser parte de minha banca, e dar muitos aportes a esta pesquisa.

Ao professor Roberto Carvalho da PUC-Rio, por aceitar e ser parte de minha banca para enriquecer este trabalho.

Ao meu esposo Paúl, por me brindar o tempo todo seu apoio, carinho, e tentar sempre em querer que dei o melhor de mim.

À Sra. Carmem Façanha, por me brindar sua ajuda nesta temporada de estudo.

Á Sra. Antonieta Middea e o Sr. Gilván do CETEM, pela grande colaboração na preparação e caracterização das amostras.

Ao pessoal do CETEM, que me ajudo e colaborou na realização desta pesquisa, em especial à Sra. Marcia Moura, Sr. Paulo Braga, Sr. Hudson, Sr. Francisco, e o Sr. Claudio, obrigada por me permitir desenvolver este trabalho.

A meus companheiros de laboratório do CETEM, que me ajudaram na execução dos testes, em especial a Lucas Andrade e Fábio.

A minhas companheiras Isabela, Tatiana, Deborah, e Aline por fazer a trajetória da pesquisa um lugar bom de trabalho.

Aos meus queridos amigos da casa XXI do departamento de Materiais (DEMa) pelo carinho demonstrado e ajuda durante o meu curso de Mestrado.

Ao Centro de Tecnologia Mineral (CETEM) pelo apoio académico e pelo serviço permitido da utilização de suas instalações laboratoriais.

Ao CNPq e à PUC-Rio, pelos auxílios concedidos, sem os quais este trabalho não poderia ter sido realizado.

O país Brasil, por ter compartilhado dois anos maravilhosos.

A todos vocês e a todas aquelas pessoas que de alguma outra forma participaram no desenvolvimento da dissertação, tem minha eterna gratidão. 


\section{Resumo}

Loayza, Pamela Elizabeth Velarde; Brocchi, Eduardo de Albuquerque; França, Silvia Cristina Alves. Estudo da eficiência de polímeros naturais (quitosana e ácido húmico) na floculação e desaguamento de polpas minerais. Rio de Janeiro, 2015. 169p. Dissertação de Mestrado Departamento de Engenharia Química de Materiais, Pontifícia Universidade Católica do Rio de Janeiro.

Rejeitos da mineração contendo grandes quantidades de finos são constantemente descartados em barragens. A recuperação da água contida nesses rejeitos depende, dentre outros fatores, da remoção de reagentes residuais e material particulado fino, que, devido às suas características de tamanho e cargas superficiais requerem tempos de sedimentação impraticáveis industrialmente. Partículas em suspensão, com diâmetro médio inferior a $2 \mu \mathrm{m}$, não podem ser removidas por sedimentação simples pois, devido às suas cargas superficiais, permanecem em repulsão mútua, promovendo uma estabilidade eletrostática da polpa. Entretanto, o estado de dispersão dessas partículas está diretamente relacionado ao potencial eletrostático de superfície, sendo necessárias etapas de desestabilização de cargas e agregação, por meio de coagulação e floculação. $\mathrm{Na}$ indústria mineral as poliacrilamidas são os polímeros comerciais mais comumente utilizados; porém, com a demanda por floculantes de menor custo e ambientalmente amigáveis, como os polímeros naturais de uso ainda incipiente, a quitosana e o ácido húmico passam a ser atrativos para sua aplicação em polpas minerais. Para este caso de estudo serão avaliados um rejeito de níquel e lama vermelha, ambos provenientes de unidades industriais. $\mathrm{O}$ pH é uma variável muito influenciável no processo, porém mediante a análise do potencial zeta foram medidas as cargas superficiais resultantes e se determinou o $\mathrm{pH}$ de trabalho para cada uma das polpas. A qualidade dos flocos formados tem forte dependência com as condições operacionais de formação como tipo de reagentes e suas combinações, porém mediante a utilização do planejamento experimental foram estudadas variáveis como concentração de sólidos, dosagens de quitosana e de ácido húmico, velocidade e tempo de agitação. Os parâmetros do processo foram otimizados por meio da obtenção e ajuste de modelos matemáticos. Os ensaios de floculação tiveram como variável de resposta a turbidez do sobrenadante e os resultados foram ajustados atendendo às normas ambientais 
vigentes para reuso da água. Para o rejeito de $\mathrm{Ni}$, em um $\mathrm{pH} 7$, obteve-se um modelo quadrático, que conferido experimentalmente com as condições otimizadas deu uma resposta de turbidez de 32 NTU. Para o caso da lama vermelha obtiveramse dois modelos: em $\mathrm{pH}=12$ obteve-se um modelo linear, que gerou uma resposta de turbidez de 33 NTU e em pH=8 obteve-se um modelo quadrático, conferido experimentalmente uma resposta de turbidez de 31 NTU. Dessa forma, nota-se que, para os polímeros estudados, é possível reduzir a turbidez de fluxos de sobrenadantes com eficiência de até $90 \%$.

\section{Palavras-chave}

Floculação; partículas finas; colóides; ácido húmico; quitosana. 


\section{Abstract}

Loayza, Pamela Elizabeth Velarde; Brocchi, Eduardo de Albuquerque (Advisor); França, Silvia Cristina Alves (Co-Advisor). Efficiency of natural polymers (chitosan and humic acid) in flocculation and dewatering of mineral slurries. Rio de Janeiro, 2015. 169p. MSc. Dissertation - Departamento de Engenharia Química e de Materiais, Pontifícia Universidade Católica do Rio de Janeiro.

Mining waste containing large amounts of fines are constantly disposed of in dams. The recovery of water contained in these wastes depends, among other factors, the removal of residuals reagents and fine particulate material, which due to their size and surface charge characteristics require of sedimentation times impractical industrially. Suspended particles with an average diameter of less than $2 \mu \mathrm{m}$, can not be removed by simple sedimentation by reason of their surface charges, remain in mutual repulsion, promoting an electrostatic stability of the pulp. However, the dispersion state of the particles is directly related to the electrostatic surface potential, and steps necessary to destabilize charges and aggregation, through coagulation and flocculation. Polyacrylamides are the most commonly used commercial polymers at the mineral industry; however, the demand for flocculants of lower cost and environmentally friendly, such as natural polymers have incipient use as chitosan and humic acid, become attractive for application in mineral slurries, for this case study will be evaluated the tailings of $\mathrm{Ni}$ and the red mud. $\mathrm{pH}$ is a very influenceable variable in the process but by an analysis of the zeta potential were measured of resulting surface charges and determined of $\mathrm{pH}$ for each of the slurries. The quality of the flakes have formed strong dependence on operating conditions of formation as a kind of reagents and their combinations, but by using the experimental design were studied variables such as of solids concentration, chitosan, humic acid, stirring speed and stirring time. With the obtained mathematical models, were the optimizations conducted of the process parameters. In tests of flocculation, it had turbidity as response variable of the supernatant and the results were adjusted taking into account the environmental standards for water reuse. To $\mathrm{Ni}$ in a $\mathrm{pH} \sim 7$, there was obtained a quadratic model, given the conditions optimized experimentally gave a turbidity response of 32 NTU. For the case of red mud was obtained two models at $\mathrm{pH} 12$ was obtained as a linear model given experimentally gave a turbidity response of 33 NTU and pH 8 
was obtained a quadratic model, given experimentally has a turbidity response of 31 NTU, which show that it is possible to reduce overflow the turbidity from 500 NTU to less than 50 NTU.

\section{Keywords}

Flocculation; fine particles; colloids; humic acid; chitosan. 


\section{Sumário}

1 Introdução 25

2. Objetivos 27

2.1. Objetivo geral 27

$\begin{array}{ll}\text { 2.2. Objetivo específico } & 27\end{array}$

3 . Revisão Bibliográfica 28

3.1. Definição de argilominerais 28

3.1.1. Rejeito de $\mathrm{Ni} \quad 28$

3.1.2. Lama vermelha $\quad 29$

3.2. Química de superfície 30

3.2.1. Origem da carga superficial $\quad 30$

3.2.2. A dupla camada elétrica (dce) 31

3.2.3. Potencial eletrocinético 35

3.2.4. Potencial zeta 36

3.3. Sistemas coloidais 38

3.3.1. Estabilidade de colóides: (Teoria DLVO) 40

3.4. Coagulação e floculação 41

3.4.1. Introdução 41

3.4.2. Floculação $\quad 42$

3.4.3. Interação polímero com partícula 43

3.4.3.1. Efeito da adesão e adsorção das partículas 46

3.4.3.2. Efeito da concentração do polímero 47

3.4.3.3. Efeito dos contraíons 48

3.4.3.4. Efeito de colisão das partículas com o polímero 49

3.4.3.5. Efeito da heterocoagulação 49

3.4.3.6. Efeito da massa molar 51

3.5. Polímeros naturais na adsorção em argilominerais 52

3.5.1. Introdução 52

3.5.2. Propiedades da quitosana 53

3.5.2.1. Solubilidade da quitosana $\quad 54$

3.5.3. Interação da quitosana com argilominerais $\quad 55$ 
3.5.4. Breve descrisão sobre os diferentes AH`s envolvidos 56

3.5.4.1. AH da SigmaAldrich 56

3.5.4.2. AH do carvão mineral 56

3.5.4.3. AH do coque mineral 56

3.5.4.4. AH do Suwanne River (IHSS) 57

3.5.4.5. AH do Pahokee Standard (IHSS) 57

3.5.5. Propiedades do ácido húmico 57

3.5.6. Interação do ácido húmico com argilominerais 60

3.5.7. Interação ácido húmico com quitosana 61

3.5.8. Interação ácido húmico com quitosana nos argilominerais 62

3.5.9. Mecanismos de reação ou de ligações na adsorção polímero/argila 63

3.5.9.1. Ligação Física ( forças de van der Waals) 63

3.5.9.2. Ligação eletrostática 63

3.5.9.3. Ponte hidrógeno 64

3.5.9.4. Interações das argilominerais com as substâncias húmicas 65

4 Materiais e métodos $\quad 66$

4.1. Materiais 66

4.2. Procedimento experimental 66

4.3. Preparação da quitosana 66

4.4. Preparação do ácido húmico $\quad 67$

4.5. Preparação das amostras $\quad 67$

4.5.1. Preparação da amostra de rejeito de $\mathrm{Ni} \quad 68$

4.5.2. Preparação da amostra de lama vermelha 68

4.6. Caracterização dos rejeitos 70

4.6.1. Análise química 70

4.6.2. Análise granulométrica $\quad 70$

4.6.3. Determinação da densidade aparente $\quad 71$

4.6.4. Determinação da Umidade 72

4.6.5. Difração de Raios X

4.6.6. Microscopia Eletrônica de Varredura (MEV) 72

4.6.7. Infravermelho 72

4.6.8. Determinação do $\mathrm{pH} \quad 73$

4.6.9. Medida do potencial eletrocinético 73

4.6.10. Testes de floculação para o rejeito de $\mathrm{Ni}$

4.6.11. Testes de floculação para a lama vermelha $\quad 74$ 
4.6.12. Medição de turbidez $\quad 75$

4.7. Análise química da água

4.8. Medida das cargas elétricas de superfície da quitosana 77

4.9. Medida das cargas elétricas de superfície do ácido húmico 78

4.10. Determinação da massa molar dos polímeros 78

5. Planejamento experimental 79

5.1. Introdução 79

5.2. Planejamento fatorial $\quad 79$

5.2.1. Decodificação do modelo matemático 81

5.3. Planejamento composto central 82

5.4. Planejamento simplex: (modelo de primeira ordem) 83

6 Discussão e resultados $\quad 85$

6.1. Análise química da água 85

6.2. Espectro de infravermelho da quitosana da SigmaAldrich 85

6.3. Espectro de infravermelho do AH (SigmaAldrich) 86

6.4. Espectro de infravermelho do AH do carvão mineral (Puc-Rio) 87

6.5. Espectro de infravermelho do $\mathrm{AH}$ do coque mineral (Puc-Rio) 88

6.6. Espectro de infravermelho do AH do Suwanne River (IHSS) 89

6.7. Espectro de infravermelho do AH do Pahokee Peat Standard (IHSS) 90

6.8. Massa molar da quitosana e do ácido húmico 91

6.9. Caracterização do rejeito de $\mathrm{Ni}$

6.9.1. Análise Química 92

6.9.2. Análise Granulométrica 93

6.9.3. Difração de Raios X 94

6.9.4. Microscopia Eletrônica de Varredura 94

6.9.5. Interação eletrostática 96

6.9.6. Determinação de tamanho de agregados (flocos) em função do pH 97

6.9.7. Pre-testes de floculação 98

6.9.7.1. Efeito de relação Acido Humico/Quitosana (AH/Q) 98

6.9.7.2. Efeito dos cátions da água na floculação 99

6.9.7.3. Efeito da quitosana e do ácido húmico a pH constante 100

6.9.7.4. Efeito de concentração de sólidos 101

6.9.8. Desenvolvimento do planejamento experimental para o rejeito de $\mathrm{Ni} 102$

6.9.8.1. Análise da variância com réplicas no ponto central 103

$\begin{array}{ll}\text { 6.9.8.2. Planejamento composto central } & 104\end{array}$ 
6.9.8.3. Obtenção do modelo matemático para o rejeito de Ni 106

6.9.8.4. Decodificação do modelo matemático para o rejeito de $\mathrm{Ni} \quad 107$

$\begin{array}{ll}\text { 6.9.8.5. Diagrama de Pareto } & 107\end{array}$

6.9.8.6. Efeitos principais da turbidez 108

6.9.8.7. Diagramas de superfície 109

6.9.9. Otimização de parâmetros 111

6.9.10. Testes de floculação com os parâmetros otimizados em função do $\mathrm{pH} \quad 112$

6.9.10.1. Efeito de floculação com quitosana 112

6.9.10.2. Efeito de floculação da quitosana com AH 113

6.9.10.3. Efeito de floculação com quitosana e AH em água de torneira e água Mili-Q

6.9.10.4. Efeito de floculação com quitosana e $A H$ em água de torneira, com quitosana e AH em água mili-Q e só da quitosana em água Mili-Q 115

6.9.11. Floculação com diferentes ácidos húmicos (AH`s) 117

6.10. Caracterização da lama vermelha 120

6.10.1. Análise Química 120

6.10.2. Análise granulométrica 121

6.10.3. Difração de Raios X 122

6.10.4. Microscopia Eletrônica de Varredura 122

6.10.5. Interação eletrostática 124

6.10.6. Determinação de tamanho de agregados (flocos) em função do $\mathrm{pH} \quad 125$

6.10.7. Pre-testes de floculação 125

6.10.7.1. Efeito da quitosana e do ácido húmico em pH 12

6.10.7.2. Efeito dos cátions da água na floculação 127

6.10.8. Desenvolvimento do planejamento experimental para a lama $\begin{array}{ll}\text { vermelha a } \mathrm{pH} 12 & 127\end{array}$

6.10.8.1. Análise da variância com réplicas no ponto central 128

6.10.8.2. Obtenção do modelo matemático para a lama vermelha 130

6.10.8.3. Decodificação do modelo matemático para a lama vermelha 130

$\begin{array}{ll}\text { 6.10.8.4. Diagrama de Pareto } & 131\end{array}$

$\begin{array}{ll}\text { 6.10.8.5. Efeitos principais da turbidez } & 131\end{array}$

6.10.8.6. Diagramas de superficie 132

6.10.9. Otimização de parâmetros com o modelo Simplex 134

6.10.10. Testes de floculação com os parámetros otimizados 136 
6.10.11، Efeitos de floculação em função do pH 138

6.10.11.1. Efeito de floculação com quitosana 138

6.10.11.2. Efeito de floculação com quitosana e AH 139

6.10.11.3. Efeito de floculação com quitosana e AH em água torneira

e água Mili-Q

6.10.11.4. Efeito da floculação com quitosana e $\mathrm{AH}$ em água de torneira, com quitosana e AH em água Mili-Q e só com quitosana em água Mili-Q 140

6.10.12. Floculação com diferentes ácidos húmicos (AH`s) 142

6.10.13. Planejamento experimental da lama vermelha a pH 8

6.10.13.1. Análise da variância com réplicas no ponto central do desenho 144

6.10.13.2. Desenho composto central 145

6.10.13.3. Análise de variância para o desenho composto central 146

6.10.13.4. Modelo matemático 147

$\begin{array}{ll}\text { 6.10.13.5. Diagrama de Pareto } & 147\end{array}$

6.10.13.6. Diagrama de contorno de superficie 148

6.10.13.7. Otimização de parâmetros 149

7 Conclusões 150

8 Recomendações e sugestões 152

9 Refêrencias Bibliográficas 153

10 Anexos 157 


\section{Lista de figuras}

Figura 1 Etapas do processo Bayer para a obtenção de bauxita (Suárez, 2012).

Figura 2 Representação esquemática da dupla camada eléctrica

difusa (Mahmoud et al., 2010)

Figura 3 Estrutura da dupla camada elétrica. Adotado de (Mahmoud

et al., 2010)

Figura 4 Análise de microscopia de força atômica (MFA) realizada para

a muscovita em diferentes pH: (a) caras e (b) bordas (Wang et al., 2014)

Figura 5 Camada estacionaria do fluído ligada à partícula dispersada

(Malvern, 2011)

Figura 6 Potencial zeta mostrando a posição do ponto isoeléctrico e os valores de $\mathrm{pH}$ onde a dispersão devería ser estável (Malvern, 2011).

Figura 7 Estrutura de duas camadas da caulinita (Wang et al., 2014).

Figura 8 Teoria de DLVO, (Malvern, 2011)

Figura 9 Forma de adsorção do polímero na partícula (Bohuslav, 1993)

Figura 10 Diferentes tipos de conformação do polímero adsorvido nas partículas (Wang et al., 2014)

Figura 11 Diferentes mecanismos de aglomeração (Bohuslav, 1993)

Figura 12 Diferentes possibilidades de interação polímero-partícula na solução (Hiemenz e Rajagopalan, 1997)

Figura 13 Mecanismos de pontes de floculação (Bohuslav, 1993)

Figura 14 a) Estrutura de um cristal da caolinita, b) Associação dos cristais da caulinita (Hunter, 1993)

Figura 15 Adsorção da montomorillonita em presença de ions de $\mathrm{Ca}$ (a) e (b) (adaptado de Bohuslav, 1993)

Figura 16 Adsorção do poli (álcool vinílico) em solução aquosa em uma superficie de látex de poliestireno, segundo a massa molar (Holmberg et al., 2002)

Figura 17 Estrutura da quitosana (poli (D-glucosamina), (Bratskaya, Schwarz e Chervonetsky, 2004)

Figura 18 Interação entre substâncias húmicas $(\mathrm{SH})$ e a camada de silicatos de argilominerais (Theng, 2012) 
Figura 19 Espectro de constantes de dissociação pK do AH, (Bratskaya,

Schwarz e Chervonetsky, 2004)

Figura 20 a), b) e c) Sustâncias húmicas em meio ácido, neutro e básico, respectivamente; d) adsorção em caulinita em pH neutro. Adaptado de Divakaran e Pillai (2004)

Figura 21 Adsorção do AH na magnetita, hematita e quarzo. Adotado de (Zhou et al., 2014)

Figura 22 Densidade de carga dos complexos de polieletrolitos $\mathrm{CH} / \mathrm{HA}$, (Bratskaya, Schwarz e Chervonetsky, 2004)

Figura 23 Troca de cátions orgânicos com cátions inorgânicos,

(Stevenson, 1994)

Figura 24 Ligações de H com superfícies de argila (Stevenson, 1994)

Figura 25 Mecanismos de adsorção das argilominerais com as substâncias húmicas, (Stevenson, 1994).

Figura 26 Soluções dos diferentes ácidos húmicos (25ppm)

Figura 27 Preparação da amostra de rejeito de $\mathrm{Ni}$

Figura 28 Preparação da amostra da lama vermelha

Figura 29 Esquema do plano de trabalho experimental 70

Figura 30 Análise granulométrica: (a) rejeito de $\mathrm{Ni}$, (b) lama vermelha 71

Figura 31 Testes de floculação no Jar test do rejeito de $\mathrm{Ni}$ 74

Figura 32 Testes de floculação no Jar test da lama vermelha 75

Figura 33 Zonas formadas nos testes de floculação (Soares, 2009)

Figura 34 Processo de sedimentação em suspensões floculadas (a) e não floculadas (b). (Soares, 2009)

Figura 35 Diagrama dos testes de floculação para o rejeito de Ni e da lama vermelha

Figura 36 Desenho composto central (Gutiérrez e De la Vara, 2008)

Figura 37 Matrix simplex desenvolvido para seis variáveis (Wolfgang, 2005)

Figura 38 Espectro de infravermelho da quitosana

Figura 39 Espectro de infravermelho do $\mathrm{AH}$ (Aldrich)

Figura 40 Espectro de infravermelho do $\mathrm{AH}$ carvão mineral (Puc-Rio) (Garces, 2015)

Figura 41 Espectro de infravermelho do $\mathrm{AH}$ do coque mineral (Puc-Rio) (Andrade, 2014)

Figura 42 Espectro de infravermelho do AH do Suwanne River (IHSS) 
Figura 43 Espectro de infravermelho do $\mathrm{AH}$ do Pahokee Peat

$\begin{array}{ll}\text { Standard (IHSS) } & 91\end{array}$

Figura 44 Determinação da massa molar da quitosana 92

Figura 45 Determinação da massa molar do ácido húmico 92

Figura 46 Distribuição granulométrica do rejeito de $\mathrm{Ni} 93$

Figura 47 Espectro de DRX para o rejeito de $\mathrm{Ni} \quad 94$

Figura 48 Micrografia das partículas de rejeito de Ni $(-20 \mu \mathrm{m}) \quad 95$

Figura 49 Micrografias das partículas de rejeito de Ni $(-20 \mu \mathrm{m})$, polpa

em pH 5

Figura 50 Micrografia das partículas de rejeito de Ni $(-20 \mu \mathrm{m})$, polpa

em pH $10 \quad 95$

Figura 51 Potencial zeta do rejeito de $\mathrm{Ni}$ em granulometria menor a $20 \mu \mathrm{m}$ e com eletrólito de $0,001 \mathrm{M}$ e $0,01 \mathrm{M} \mathrm{KNO}_{3}$ ) e quitosana (solução pura a 1000 ppm) e do ácido húmico (solução pura a 100 ppm), em $\begin{array}{ll}\text { água Mili-Q. } & 97\end{array}$

Figura 52 Agregação de partículas do rejeito de $\mathrm{Ni}(0.1 \%)$ em função do $\mathrm{pH}$, no Malvern Mastersizer 2000P, em água Mili-Q.

Figura 53 Turbidez da polpa do rejeito de $\mathrm{Ni}(0.5 \%)$ sem flocular (271 NTU), em água torneira, com 225 rpm, no jar test.

Figura 54 Adsorção em diferentes porcentagens de $A H / Q$ no rejeito de $\mathrm{Ni}(0,5 \%)$, em $225 \mathrm{rpm}$, no jar test

Figura 55 Adsorção da quitosana (680 g/t) na polpa do rejeito de $\mathrm{Ni}$ (0,25\% de sólidos), em 225 rpm, no jar test.

Figura 56 Adsorção da quitosana e do $\mathrm{AH}$, no rejeito de $\mathrm{Ni}(0,5 \%$ de sólidos) em pH 6,7, em 225 rpm, no jar test.

Figura 57 Adsorção da quitosana (680 g/t) e AH (80 g/t) nas partículas do rejeito de $\mathrm{Ni}$, em pH 7 e 225 rpm, no jar test.

Figura 59 Gráfica dos efeitos principais das variáveis sobre a turbidez 108 Figura 60 Diagrama de superfície AH-Conc. Sólidos-Quitosana

Figura 61 Diagrama de superfície Veloc. de agitação-Conc de sólidosQuitosana

Figura 62 Diagrama de superfície Tempo de agitação-Conc de sólidos- $\mathrm{AH}$

Figura 63 Diagrama de superfície Velocidade de agitação-Conc de sólidos-AH 
Figura 64 Diagrama de superfície Tempo de agitação-Conc de

sólidos-AH

Figura 65 Floculação com 2,15\% de sólidos de rejeito de Ni, com

quitosana $(24,9 \mathrm{~g} / \mathrm{t})$, em água torneira e em água mili-Q, em 119 rpm, no jar test.

Figura 66 Floculação com $2,15 \%$ de sólidos do rejeito de $\mathrm{Ni}$, quitosana $(24,9 \mathrm{~g} / \mathrm{t})$ e $\mathrm{AH}(6,3 \mathrm{~g} / \mathrm{t})$ e só com quitosana $(24,9 \mathrm{~g} / \mathrm{t})$ em água torneira, a 119 rpm, no jar test.

Figura 67 Floculação com 2,15\% de sólidos do rejeito de Ni, quitosana $(24,9 \mathrm{~g} / \mathrm{t})$ e $\mathrm{AH}(6,3 \mathrm{~g} / \mathrm{t})$, em água torneira e água Mili-Q respectivamente, em 119 rpm, no jar test.

Figura 68 Floculação de rejeito de níquel (2,15\% de sólidos): i) em presença de quitosana $(24,9 \mathrm{~g} / \mathrm{t})$ e de $\mathrm{AH}(6,3 \mathrm{~g} / \mathrm{t})$ em água da torneira, ii) quitosana (24,9 g/t) e de $\mathrm{AH}(6,3 \mathrm{~g} / \mathrm{t})$ em água Mili-Q; e iii) quitosana $(24,9 \mathrm{~g} / \mathrm{t})$ em água Mili-Q, em 119 rpm, no jar test.

Figura 69 Floculações do rejeito de $\mathrm{Ni}$ em diferentes pHs, com quitosana $(24,9 \mathrm{~g} / \mathrm{t})$ e com $\mathrm{AH}(6,3 \mathrm{~g} / \mathrm{t})$.

Figura 70 Floculação do rejeito de Ni (2,15\%), com quitosana $(24,9 \mathrm{~g} / \mathrm{t})$ e de ácido húmico (6,3 g/t), em 119 rpm, no jar test.

Figura 71 Floculação do rejeito de $\mathrm{Ni}$ em pH 3, quitosana $(24,9 \mathrm{~g} / \mathrm{t}) \mathrm{e}$ ácido húmico $(6,3 \mathrm{~g} / \mathrm{t})$.

Figura 72 Floculação do rejeito de $\mathrm{Ni}$ em pH 7, quitosana $(24,9 \mathrm{~g} / \mathrm{t}) \mathrm{e}$ ácido húmico $(6,3 \mathrm{~g} / \mathrm{t})$.

Figura 73 Distribuição granulométrica da lama vermelha

Figura 74 Espectro de DRX para a lama vermelha

Figura 75 Micrografia das partículas de lama vermelha $(-20 \mu \mathrm{m})$

Figura 76 Micrografias das partículas de lama vermelha $(-20 \mu \mathrm{m})$, polpa em pH 5

Figura 77 Micrografias das partículas de lama vermelha (-20 $\mu \mathrm{m})$, polpa em $\mathrm{pH} 12$

Figura 78 Potencial zeta da lama vermelha em granulometria menor a 20 $\mu \mathrm{m}$ e com eletrólito de $0,001 \mathrm{M} \mathrm{e} 0,01 \mathrm{M} \mathrm{KNO}_{3}$ ) e quitosana (solução pura a 1000 ppm) e do ácido húmico (solução pura a 100 ppm), em água Mili-Q. 124 Figura 79 Agregação de partículas da lama vermelha (0.1\%) em função do $\mathrm{pH}$, no Malvern Mastersizer 2000P, em água Mili-Q.

Figura 80 Turbidez da polpa da lama vermelha $(0,25 \%$ de sólidos), sem 
flocular (550 NTU).

Figura 81 Adsorção da quitosana e do ácido húmico em diferentes

dosagens na lama vermelha (1\%) em pH 12, em $225 \mathrm{rpm}$, no jar test.

Figura 82 Adsorção da quitosana (680 g/t) na lama vermelha $(0,25 \%$ de sólidos), em pH 12, em 225 rpm, no jar test.

Figura 83 Diagrama de Pareto a pH 12.

Figura 84 Efeitos principais da turbidez.

Figura 85 Diagrama de superfície AH-Conc de sólidos-Quitosana.

Figura 86 Diagrama de superfície Veloc. de agitação-Conc de sólidos-

quitosana.

Figura 87 Diagrama de superfície Tempo de agitação-Conc de sólidosquitosana.

Figura 88 Diagrama de superfície Veloc. de agitação-Conc de sólidos - $\mathrm{AH}$.

Figura 89 Diagrama de superfície Tempo de agitação-Conc de sólidos

- $\mathrm{AH}$.

Figura 90 Floculação da lama vermelha ( $0,6 \%$ de sólidos), com quitosana (1289 g/t) e AH (10 g/t), em pH 12, em 179 rpm, no jar test.

Figura 91 Floculação da lama vermelha $(0,6 \%)$, com quitosana (1289 g/t) e AH (10 g/t), e só com quitosana (1289 g/t), em 179 rpm, em pH=12, no jar test.

Figura 92 Floculação da lama vermelha $(0,6 \%)$, com quitosana $(1289 \mathrm{~g} / \mathrm{t})$, em água da torneira e Mili-Q, em 179 rpm, no jar test.

Figura 93 Floculação da lama vermelha $(0,6 \%)$, com quitosana (1289 g/t) e de $\mathrm{AH}(10 \mathrm{~g} / \mathrm{t})$ e só com quitosana (1289 g/t) em água torneira, em 179 rpm, no jar test.

Figura 94 Floculação da lama vermelha $(0.6 \%)$, com quitosana (1289 g/t) e AH (10 g/t), em água torneira e em água Mili-Q, em 179 rpm, no jar test. Figura 95 Floculação da lama vermelha $(0.6 \%)$, com quitosana (1289 g/t) e AH (10 g/t), em água torneira, com quitosana (1289 g/t) e AH (10 g/t), em água Mili-Q.e só com quitosana (1289 g/t) em água Mili-Q, em 179 rpm, no jar test.

Figura 96 Floculações da lama vermelha, com quitosana (1289 g/t) e AH $(10 \mathrm{~g} / \mathrm{t}) \mathrm{em} \mathrm{pH}$ de 6, 8, 10 e 12, em $179 \mathrm{rpm}$, no jar test.

Figura 97 Floculação da lama vermelha $(0.6 \%)$, com quitosana $(1289 \mathrm{~g} / \mathrm{t})$ e com diferentes ácidos húmicos de diferentes fontes (10 g/t), em pH 12 , 
em 179 rpm, no jar test. $\quad 142$

Figura 98 Floculação da lama vermelha, em pH 8, no jar test. 143

$\begin{array}{ll}\text { Figura } 99 \text { Diagrama de Pareto a pH } 8 & 147\end{array}$

Figura 100 Efeito principais das variáveis em pH 8. 148

Figura 101 Contornos da superfície estimada da floculação em pH 8. 


\section{Lista de tabelas}

Tabela 1 Pontos isoelétricos de minerais do rejeito de $\mathrm{Ni}$

Tabela 2 Pontos isoelétricos de minerais da lama vermelha (Liu,

Naidu e Ming, 2013).

Tabela 3 Comparação dos polímeros naturais com os polímeros sintéticos

Tabela 4 Matriz das variáveis independentes e interações em escala codificada.

Tabela 5 Fatores do Planejamento experimental do rejeito de Ni.

Tabela 6 Fatores do Planejamento experimental da lama vermelha.

Tabela 7 Equações para determinar os coeficientes do modelo

decodificado.

Tabela 8 Valores de $\alpha$ segundo o número de fatores (Gutiérrez e

De la Vara, 2008)

Tabela 9 Análise química da água.

Tabela 10 Análise química do rejeito de $\mathrm{Ni}$.

Tabela 11 Densidade e umidade do rejeito de Ni.

Tabela 12 Planejamento experimental para o rejeito de $\mathrm{Ni}$, em $\mathrm{pH} 7$

Tabela 13 Análise da variância.

103

Tabela 14 Desenho composto central para o rejeito de Ni.

105

Tabela 15 Análise de variância do desenho composto central.

106

Tabela 16 Coeficiente de correlação do modelo de segundo ordem.

106

Tabela 17 Parâmetros otimizados do rejeito de Ni para uma turbidez de 35 NTU.

Tabela 18 Análise química da lama vermelha.

Tabela 19 Densidade e umidade da lama vermelha.

Tabela 20 Planejamento experimental para a lama vermelha, em pH 12.128

Tabela 21 Análise da variância para os testes com a lama vermelha

Tabela 22 Cálculo do vértice 7

Tabela 23 Cálculo do primer centro de gravidade.

Tabela 24 Cálculo do vértice 8.

Tabela 25 Cálculo do vértice 12

Tabela 26 Parâmetros optimizados da lama vermelha para uma turbidez de 35 NTU 
Tabela 27 Fatores do planejamento experimental em pH 8.

Tabela 28 Planejamento experimental da lama vermelha em pH de $8 . \quad 144$

Tabela 29 Análise da variância para lama vermelha em pH 8.

Tabela 30 Desenho central composto em pH $8 \quad 146$

Tabela 31 Análise de variância do desenho composto central em pH 8146

Tabela 32 Coeficiente de correlação do modelo de segundo ordem 147

Tabela 33 Parâmetros optimizados para 35 NTU em pH 8

Tabela 34 Avaliação estadística dos íons da água da torneira 157

Tabela 35 Determinação da densidade do rejeito de Ni 159

Tabela 36 Distribuição granulométrica do rejeito de $\mathrm{Ni} \quad 160$

Tabela 37 Soma dos quadrados dos efeitos para cada tratamento. 161

Tabela 38 Cálculos estatísticos para determinar a análise da variância (Ayres, Torres e Ponce, 2000) 161

Tabela 39 Matriz codificada do desenho composto central para 5 variáveis 162

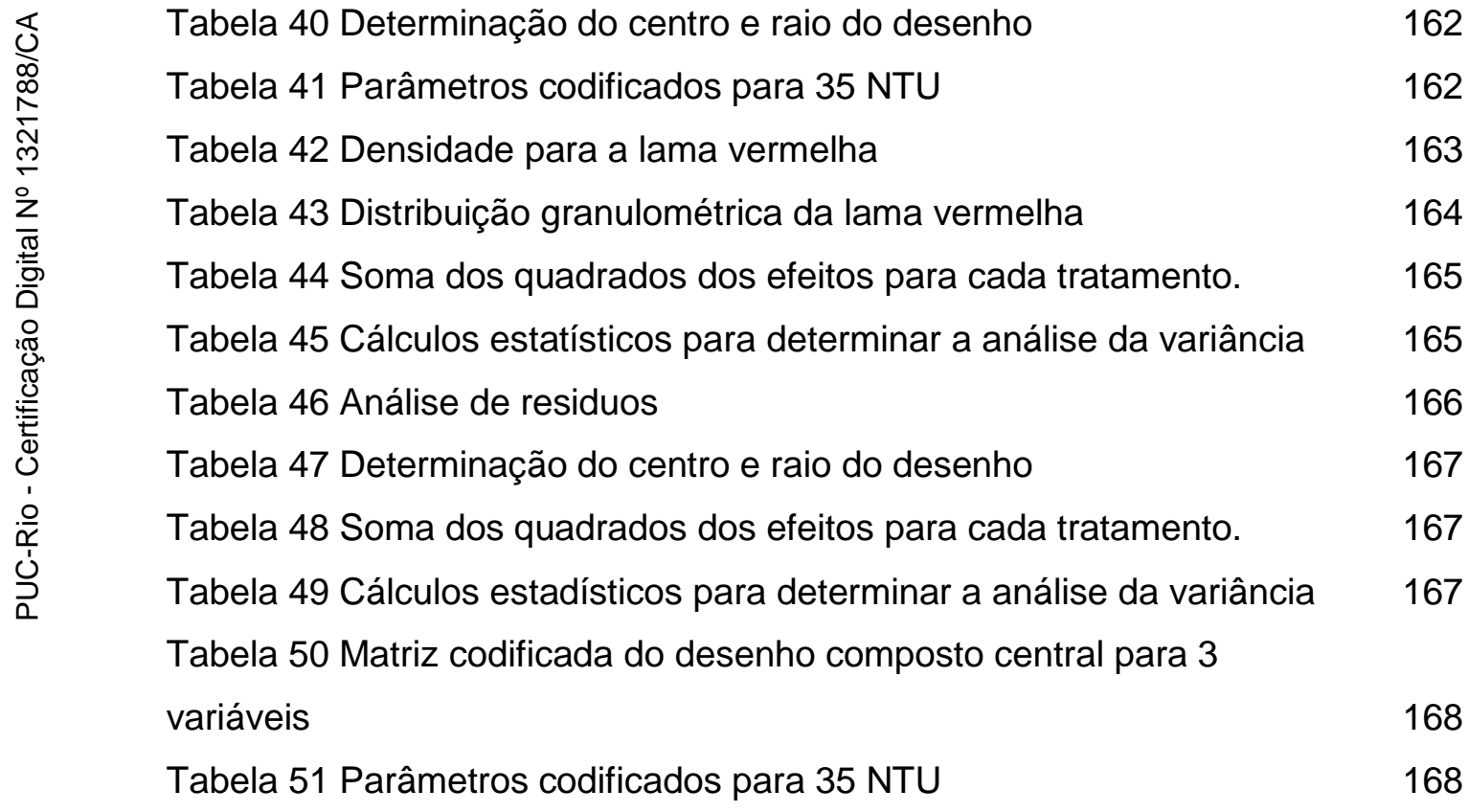

Tabela 52 Pontos de percentagem de distribuição F: pontos superiores a 1\% (Ayres, Torres e Ponce, 2000) 169 


\section{Nomenclatura}

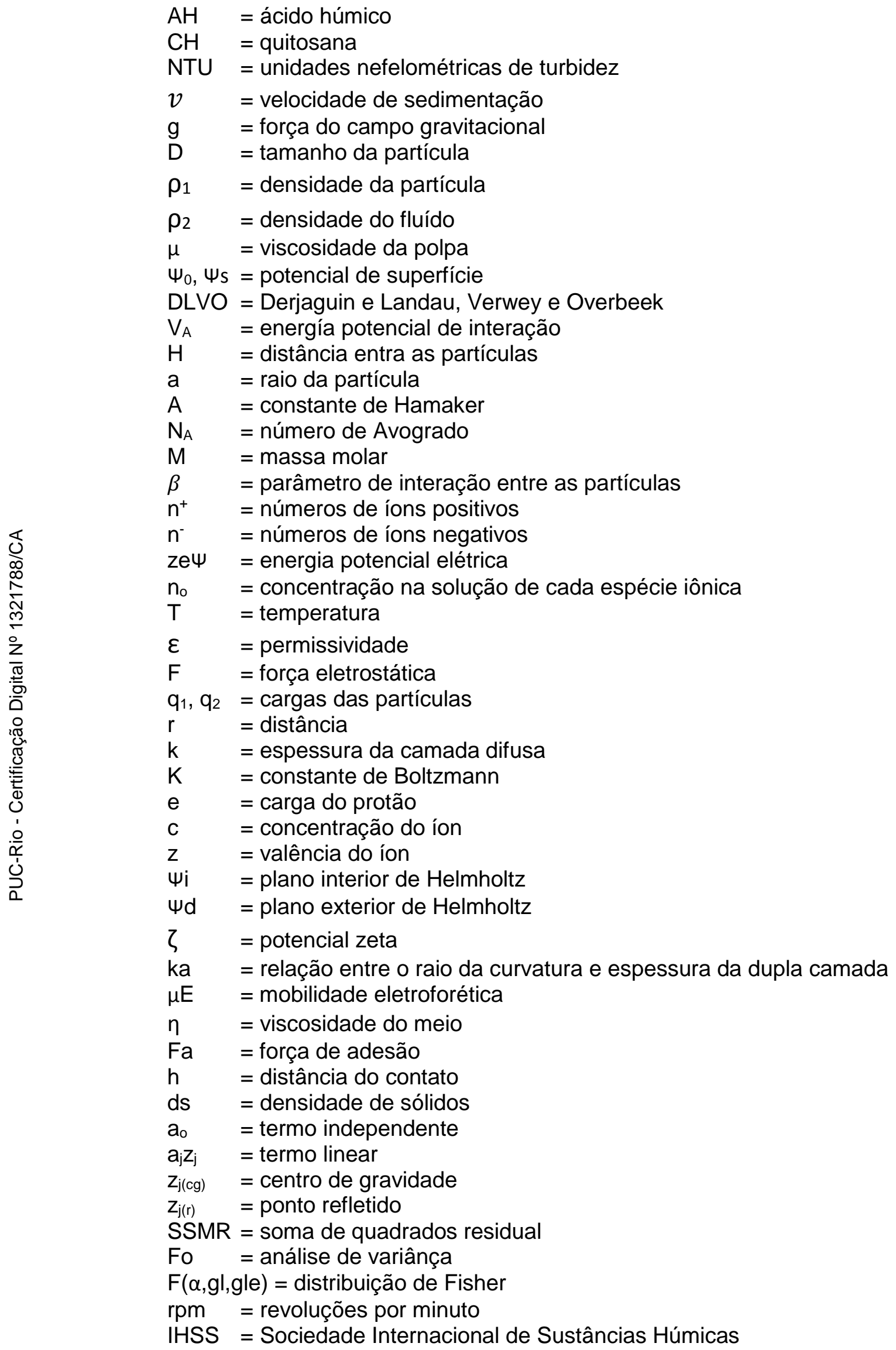


Deus é amor e quem viva com amor, vive com Deus e Deus com ele. Se aguentamos todo dor e sofrimento com fé e amor, encontraremos a felicidade no Senhor. Juan (seu apóstolo) 
1

\section{Introdução}

Os colóides podem apresentar propriedades elétricas que criam uma força de repulsão que reduz a aglomeração e a sedimentação das partículas. O estado de dispersão dessas partículas está diretamente relacionado ao potencial eletrostático de superfície (Liu, Naidu e Ming, 2013), sendo necessárias etapas de desestabilização de cargas e agregação, por meio de coagulação e floculação. $\mathrm{Na}$ maior parte dos efluentes industriais as partículas de um colóide possui carga negativa.

Nesse trabalho será abordado o estudo dos colóides contidos em rejeitos minerais com elevada concentração de finos, como o rejeito oriundo da concentração de minérios sulfetados de niquel (rejeito de $\mathrm{Ni}$ ) e da lama vermelha, cuja remoção se constitui em um grande desafio de sustentabilidade para as indústrias de mineração. A exemplo, a indústria de alumínio gera cerca de 90 milhões de toneladas de resíduos alcalinos (lama vermelha) por ano e o tratamento adequado para descarte é essenciai, devido às suas propriedades corrosivas e efeitos nocivos relacionados ao meio ambiente (Liu, Naidu e Ming, 2013).

A demanda crescente por tecnologias ambientalmente amigáveis promove a necessidade de se utilizar polímeros naturais, como a quitosana e o ácido húmico, os quais podem substituir os polímeros sintéticos. A quitosana é obtida a partir da desacetilação da quitina e tem sido utilizada como um adsorvente para íons de metais de transição e espécies orgânicas (como o ácido húmico - $A H$ ), pela protonação, em meio ácido, dos seus grupos amino $\left(-\mathrm{NH}_{2}\right)$ e os hidroxi $(-\mathrm{OH})$ (Chang e Juang, 2004; Zhang e Bai, 2003). O ácido húmico (AH), que é uma subclasse de substâncias húmicas, apresenta grupos carboxílicos e fenólicos, os quais predominantemente transportam as cargas negativas em soluções aquosas (Zhang e Bai, 2003).

O processo de adsorção da quitosana em argilas, como a caulinita, foi estudado por Li et al. (2013) que concluíram que a adsorção depende da densidade de cargas da quitosana, a qual é dependente de sua protonação. A maioria dos grupos amina é protonada, principalmente abaixo de valores de 
pKa 6,5 e são desprotonados em meio básico, o que significa que nessa faixa de $\mathrm{pH}$ não podem neutralizar cargas negativas coloidais.

A adsorção dos argilominerais no $\mathrm{AH}$, diminui com o incremento de $\mathrm{pH}$ de 3 a 6 , seguido de uma ligeira queda até $\mathrm{pH}$ 9, que ocorre devido às mudanças da ionização dos grupos carboxílicos, os quais estão fortemente ionizados a $\mathrm{pH}<6$. Este efeito desfavorável na faixa básica de $\mathrm{pH}$ pode ser parcialmente compensado pela presença de cátions polivalentes (Theng, 2012). Os principais cátions polivalentes responsáveis pela ligação dos $\mathrm{AH}^{\prime} \mathrm{s}$ com as argilas estão preferencialmente na seguinte ordem (Stevenson, 1994): $\mathrm{Fe}^{3+}=\mathrm{Al}^{3+}>\mathrm{H}^{+}>\mathrm{Ca}^{2+}>$ $\mathrm{Sr}^{2+}>\mathrm{Mg}^{2+}>\mathrm{K}^{+}>\mathrm{Na}^{+}>\mathrm{Li}^{+}$.

O objetivo do presente estudo, apresentado no Capítulo 2, foi avaliar a interação da quitosana, com o ácido húmico, na floculação de partículas ultrafinas dos rejeitos minerais mencionados, visando a maior eficiência nos processos de separação sólido-líquido.

No Capítulo 3 é apresentada uma revisão bibliográfica sobre química de superfície de sistemas coloidais, processos de agregação de partículas (coagulação e floculação) fortemente dependentes das propriedades de superfície e das interações entre superfície sólida-reagentes, com foco nas propriedades dos polímeros quitosana e ácido húmico.

No Capítulo 4, a metodologia é apresentada de forma individualizada, respeitando as particularidades de cada polímero floculante, bem como de cada rejeito estudado, abordando desde a caracterização química e mineralógica dos materiais ao processo de sedimentação da polpa floculada.

O Capítulo 5 é dedicado ao planejamento de experimentos utilizado nesse trabalho.

No Capítulo 6 são apresentados e discutidos os resultados desse trabalho, abordando a parte experimental de produção de polpas floculadas e também a avaliação dos parametros significativos no processo de floculação, utilizando o planejamento experimental para obter os modelos matemáticos e a otimização de seus parâmetros.

Finalmente, no Capítulo 7 são apresentadas as conclusões do trabalho, bem como propostas para trabalhos futuros que venham a complementar esse estudo. 
2

\section{Objetivos}

\subsection{Objetivo geral}

Avaliar a aplicação dos polímeros naturais (quitosana e ácido húmico), nos processos de coagulação e floculação de polpas minerais, utilizando as propriedades das cargas superficiais, para melhorar a eficiência dos processos de separação sólido-líquido, visando o reaproveitamento da água no processo.

\subsection{Objetivo específico}

- Avaliar a interação do ácido húmico com a quitosana nas operações de agregação de partículas (coagulação e floculação) e sedimentação.

> Avaliar os efeitos e interações das variáveis do processo de floculação aplicando o planejamento de experimentos.

> Obter modelos matemáticos que descrevam o comportamento da floculação a respeito das variáveis estudadas.

> Otimizar os parâmetros do processo de floculação nas polpas minerais. 
3

\section{Revisão Bibliográfica}

\subsection{Definição de argilominerais}

\subsubsection{Rejeito de $\mathrm{Ni}$}

O Brasil produziu, no ano de 2013, cerca de 13 milhões de toneladas de concentrado de níquel, as quais são provenientes de minérios oxidados e sulfetados (Sumário Mineral, 2014). Estes últimos são beneficiados pelo processo de flotação, porém uma grande quantidade de rejeito ainda contendo minerais portadores de níquel é descartada nas barragens. O reaproveitamento desse rejeito, por flotação em colunas, por exemplo, necesita de novas etapas de cominuição, gerando grande quantidade de material particulado fino e colóides, os quais precisam ser removidos, para posibilitar a reutilização da água de processo.

A remoção do material particulado envolve etapas de agregação de partículas, a qual torna-se desafiadora em termos tecnológicos e econômicos, devido à necessidade de uso de polímeros para a floculação dessas partículas. Entretanto, nem sempre os polímeros convencionais de alta massa molar são eficientes na captura desses colóides, havendo a necessidade de estudo de floculantes alternativos.

Tabela 1 Pontos isoelétricos de minerais do rejeito de $\mathrm{Ni}$

\begin{tabular}{|c|c|}
\hline Composição mineralógica & PIE (ponto isoelétrico) \\
\hline Quarzo (SiO 2$)(\mathrm{Liu}, \mathrm{Naidu}$ e Ming, 2013) & 2,6 \\
\hline Caolinita (Al2Si2O5(OH)4) (Yuehua et al., 2004) & 4,3 \\
\hline Montmorillonita ((Mg, & 2,5 \\
Ca)O.Al2O3Si5O10.nH2O) (Beddin, 2002) & 2,8 \\
\hline Pirita (FeS2) (Taís e Nito, 2007) & 7,0 \\
\hline Dolomita (CaMg(CO3)2) (Pereira e Pereira, \\
2013)
\end{tabular}




\subsubsection{Lama vermelha}

O aluminio é o metal não ferroso mais consumido industrialmente, devido às suas caracteristias físico-químicas. A bauxita é a rocha que contém os minerais portadores de alumínio e a sua extração é feita por meio do processo Bayer (Figura 1), para obtenção de alumina $\left(\mathrm{Al}_{2} \mathrm{O}_{3}\right)$, gerando o resíduo conhecido como lama vermelha, com elevada causticidade ( $\mathrm{pH} 12)$ e grande quantidade de finos (10\% de partículas com diâmetro menor que $2 \mu \mathrm{m}$ ) (Suárez, 2012).

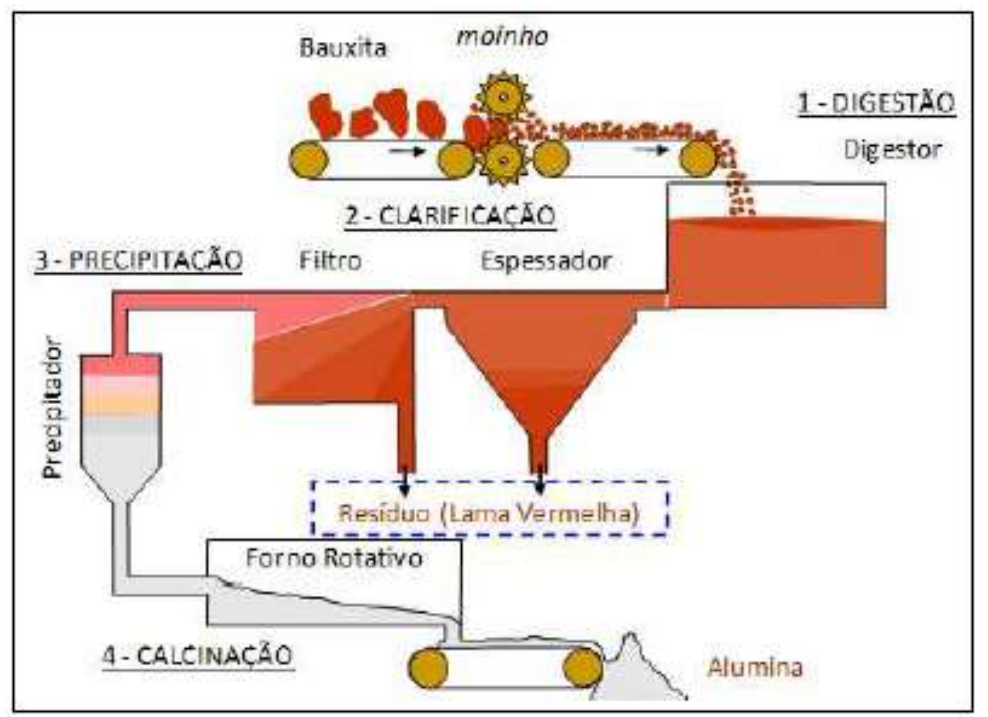

Figura 1 Etapas do processo Bayer para a obtenção de bauxita (Suárez, 2012).

A lama vermelha é uma mistura heterogênea de sólidos de partículas finas, que consiste principalmente de hematita, gibbsita, quartzo, óxido de titânio e carbonatos. O comportamento físico e químico da lama vermelha, na reologia, agregação e coagulação, hidratação da superfície, capacidade de adsorção e comportamento redox, são altamente dependentes da carga de superfície dos seus constituintes. Os minerais que contém Al e Fe influenciam na carga resultante da lama vermelha e têm forte interferência no $\mathrm{pH}$ (Tabela 2), apresentando cargas positivas em meio ácido e negativas em meio alcalino (Liu, Naidu e Ming, 2013). 
Tabela 2 Pontos isoelétricos de minerais da lama vermelha (Liu, Naidu e Ming, 2013).

\begin{tabular}{|c|c|c|}
\hline Composição mineralógica & PIE (ponto isoelétrico) & Intervalo de pH \\
\hline Quarzo $\left(\mathrm{SiO}_{2}\right)$ & 2,6 & $2,3-2,8$ \\
\hline Hematita $\left(\mathrm{Fe}_{2} \mathrm{O}_{3}\right)$ & 7,8 & $6,0-9,1$ \\
\hline Magnetita $\left(\mathrm{Fe}_{3} \mathrm{O}_{4}\right)$ & 6,5 & $5,7-6,8$ \\
\hline Goetita $(\mathrm{FeO}(\mathrm{OH}))$ & 7,8 & $6,6-8,6$ \\
\hline Calcita $(\mathrm{CaCO})$ & 8,2 & - \\
\hline Gibsita $\left(\mathrm{Al}(\mathrm{OH})_{3}\right)$ & 6,5 & $3,8-9,9$ \\
\hline Bohemita $(\mathrm{AlO}(\mathrm{OH}))$ & 8,9 & $8,1-9,7$ \\
\hline Anatásio $\left(\mathrm{TiO}_{2}\right)$ & 5,5 & $5,3-5,6$ \\
\hline Magnesita $\left(\mathrm{MgCO}_{3}\right)$ & 7,7 & $6,2-8,7$ \\
\hline
\end{tabular}

\subsection{Química de superfície}

\subsubsection{Origem da carga superficial}

A maioria das substâncias adquire uma carga elétrica superficial quando entram em contato com um meio polar (exemplo: aquoso). Os principais mecanismos de criação dessas cargas podem ser: ionização, em que as cargas adquiridas dependem do $\mathrm{pH}$ da solução e por adsorção de íons. Na carga superficial, pode surgir a adsorção desigual de íons de cargas de sinais opostos e a adsorção iônica pode ser positiva ou negativa.

Geralmente as superfícies em contato com meios aquosos se apresentam mais frequentemente com carga negativa, e não positiva. Isso acontece porque os cátions são mais hidratados, apresentando assim maior tendência de permanecer no meio aquoso do que os ânions. E os ánions são polarizáveis.

As superfícies que apresentam cargas tendem a adsorver íons de carga oposta especialmente de carga mais elevada; é possível que essa adsorção de íons de carga oposta inverta a carga elétrica da superfície. Essa carga superficial influência a distribuição dos íons próximos a ela, no meio polar. ĺons de carga oposta (contra-íons) são atraídos pela superfície e íons de carga de mesmo sinal (co-íons) são repelidos para mais longe da superfície (Shaw, 1975). 


\subsubsection{A dupla camada elétrica (dce)}

A teoria da dupla camada elétrica trata da distribuição de íons, e da intensidade dos potenciais elétricos que ocorrem na superfície carregada. É constituída por duas regiões, uma interna que inclui os íons adsorvidos, e uma região difusa na qual os íons se encontram distribuídos de acordo com a influência de forças elétricas e do movimento térmico (Shaw, 1975).

Para compreender os fenômenos que ocorrem na superfície de uma partícula carregada em meio líquido pode-se recorrer às relações da eletrostática, o tratamento quantitativo mais simples da parte difusa da dupla camada foi desenvolvido por Gouy e Chapman, e se baseia no modelo seguinte: (Figura 2).

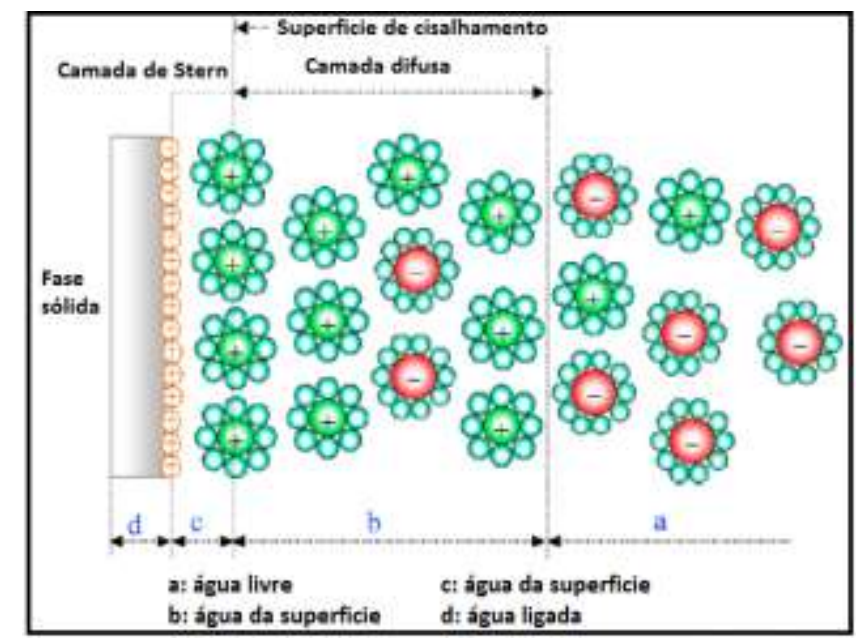

Figura 2 Representação esquemática da dupla camada eléctrica difusa (Mahmoud et al., 2010)

A superfície é supostamente plana, os íons na camada difusa estão como cargas puntiformes distribuídas de acordo com a distribuição de Boltzman, onde o solvente influencia a dupla camada através de sua constante dielétrica, que tem o mesmo valor em toda a parte difusa. A distribuição de Boltzmann é utilizada para obter a concentração de qualquer íon próximo à superfície carregada imersa em um eletrólito (Shaw, 1975).

$$
\begin{aligned}
& n+=n_{\mathrm{o}} \exp \left(\frac{-z e \Psi}{K T}\right) \\
& n-=n_{\mathrm{o}} \exp \left(\frac{+z e \Psi}{K T}\right)
\end{aligned}
$$


Onde $\mathrm{n}+\mathrm{e} \mathrm{n}$ - são os números de íons positivos e negativos por unidade de volume, respectivamente, em pontos nos quais $+\mathrm{ze} \Psi$ e $-z e \Psi$ é a energia potencial elétrica respectivamente, $\mathrm{n}_{\circ}$ corresponde a concentração na solução de cada espécie iónica, $\mathrm{K}$ é a constante de Boltzmann e $\mathrm{T}$ é a temperatura.

A densidade de carga total $\rho$ em pontos de potencial $\Psi$ é dada por:

$$
\rho=z e(n+-n-)
$$

Substituindo nas equações 1 e 2 :

$$
\rho=-2 \mathrm{zen} \operatorname{senh} \frac{\mathrm{ze} \Psi}{\mathrm{KT}}
$$

A relação entre $\rho$ e $\Psi$ é dada pela de Equação de Poisson, que para uma dupla camada plana assume a forma da Equação (5):

$$
\frac{d^{2} \Psi}{d x^{2}}=-\frac{\rho}{\varepsilon}
$$

Onde $\varepsilon$ é a permitividade (expressão racionalizada $F=q 1 q 2 / 4 \pi \varepsilon r^{2}$, onde $F$ é a força eletrostática de entre as cargas $q_{1}$ e $q_{2}$, separadas por uma distância r).

Combinando as equações 4 e 5, tem-se a Equação (6):

$$
\frac{d^{2} \Psi}{d x^{2}}=\frac{2 z e n_{\mathrm{o}}}{\varepsilon} \operatorname{senh} \frac{z e \Psi}{K T}
$$

Considerando as condições limitantes $(\Psi=\Psi$ 。 quando $x=0$, e $\Psi=0, d \psi / d x=0$ quando $x=\infty$ ), a espessura da camada difusa é mostrada na Equação (7):

$$
k=\left(\frac{2 e^{2} n_{\mathrm{o}} z^{2}}{\varepsilon K T}\right)^{1 / 2}=\left(\frac{2 e^{2} N A c z^{2}}{\varepsilon K T}\right)^{1 / 2}
$$

Para baixos valores de potenciais (menores a $25,6 \mathrm{mV}$ e a $25^{\circ} \mathrm{C}$ ) é possível determinar a espessura da camada difusa mediante aproximação de DebyeHuckel (Bohuslav, 1993). Então:

onde: e é a carga do protão, $N A$ é o número de Avogadro $\left(6,02 \times 10^{23}\right)$, $\varepsilon$ a permissividade do vácuo $\left(8.854 \times 10^{-12} \mathrm{~kg}^{-1} \mathrm{~m}^{-3} \mathrm{~s}^{4} \mathrm{~A}^{2}\right)$, e $\mathrm{K}$, a constante de Boltzmann $\left(1.38 \times 10^{-23}\right)$ a uma temperatura de $298 \mathrm{~K}$., A espessura da camada difusa (1/k) para uma camada plana e considerando um eletrólito simétrico, é: (Shaw, 1975)

$$
k=0,328 \times 10^{10}\left(\frac{c z^{2}}{m o l d m-3}\right)^{1 / 2} m^{-1}
$$

Onde c é a concentração do íon e z é a valência do íon. 
E para eletrólitos assimétricos, a espessura da dupla camada poderá ser calculada se consideramos z como a carga do contra-íon.

Como a estabilidade coloidal de partículas carregadas depende da repulsão eletrostática, e está por sua vez depende da espessura da camada difusa (1/k), então:

> Quanto maior a concentração de eletrólito no meio, menor será a distância na qual ainda existe potencial eletrostático $(\Psi)$ significativo e, portanto, mais favorável será a agregação das partículas.

> E os íons de maiores valências provocam a diminuição da distância na qual ainda existe potencial eletrostático $(\Psi)$ significativo e, portanto, favorecem a agregação das partículas.

Os íons adsorvidos especificamente são aqueles ligados à uma superfície por forças eletrostáticas ou forças de van der Waals, e se localizam na camada de Stern, ou seja, entre a superfície e o plano de Stern e os íons cujos centros se localizam além do plano de Stern constituem a parte difusa da dupla camada, para o qual se considera o tratamento de Gouy-Chapman (Shaw, 1975).

Este modelo de Gouy e Chapman é apresentado na Figura 3, a primeira camada está no plano interior de Helmholtz e é representado com potencial $\Psi \mathrm{i}$, onde os co-íons e contra-íons não são hidratados e estão especificamente adsorvidos à superfície. A segunda camada é definida pelo plano exterior de Helmholtz com potencial $\Psi \mathrm{d}$, que consiste em uma camada limite, hidratada, e com contra-íons parcialmente hidratados. A terceira camada é a camada difusa, composto de co-iões móveis e contraíons, no qual reside o plano de cisalhamento. O potencial $\Psi$ s representa o potencial supercial

O plano de cisalhamento, é um plano imaginário que separa os íons que estão imóveis na superfície daqueles que estão móveis em solução.O potencial zeta ( $\zeta$ ), neste plano pode ser determinada experimentalmente, e é, portanto, um importante parâmetro na ciência colóide para determinar a estabilidade de partículas (Mahmoud et al., 2010). 


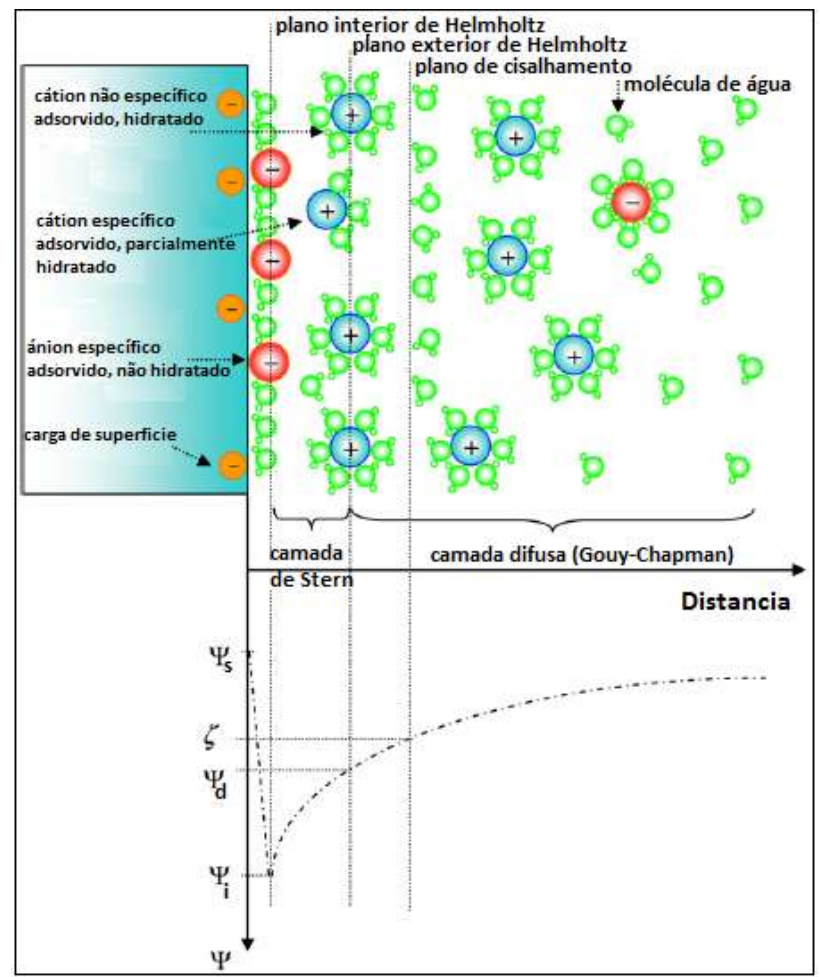

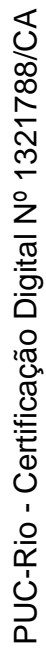

Figura 3 Estrutura da dupla camada elétrica. Adotado de (Mahmoud et al., 2010)

As Figuras 4 (a) e (b) apresentam resultados obtidos por (Yan et al., 2011), mostrando que a transição de uma força de atração para uma força de repulsão entre a ponta de prova e a borda da muscovita é mais intensa em pH 5,6.

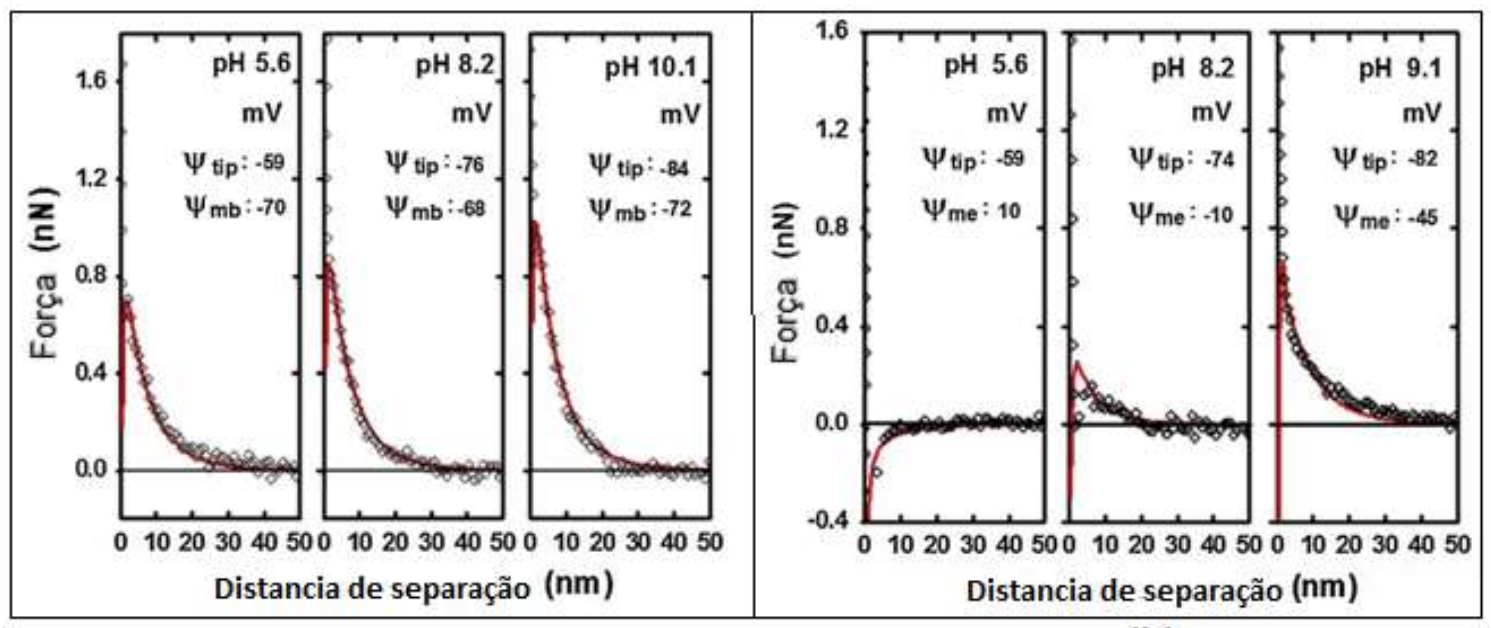

(a)

(b)

Figura 4 Análise de microscopia de força atômica (MFA) realizada para a muscovita em diferentes pH: (a) caras e (b) bordas (Wang et al., 2014) 
A Figura 4 (a) apresenta as caras as forças de interação são todas repulsivas, mesmo com o aumento gradual do $\mathrm{pH}$. Para a avaliação de forças de interação nas bordas Figura 4 (b), nota-se a sua inversão a partir do pH 8,2 (dentre os avaliados), aumentando a sua intensidade até pH 9. Isso sugere que a carga resultante das bordas da muscovita é fortemente dependente do $\mathrm{pH}$. Esses resultados são corroborados por (Wang et al., 2014).

\subsubsection{Potencial eletrocinético}

O comportamento eletrocinético das partículas dependem do potencial na superfície de cisalhamento, entre a superficie carregada e a solução de eletrólito. Esse potencial é o potencial zeta $(\zeta)$.

Considerar-se que, além dos íons situados na camada de Stern, uma certa quantidade de solvente (aquoso) será também ligada à superfície carregada, participando assim da unidade eletrocinética. Porém, o plano de cisalhamento encontra-se um pouco mais afastado da superfície do que o plano de Stern; assim, é razoável considerar que o $\zeta$ será um pouco menor em relação ao $\Psi_{\mathrm{d}}$, mas em experimentos comprovaram considerar idênticos os planos $\Psi_{\mathrm{d}}$ e $\zeta$ (Shaw, 1975).

A eletrocinética é o estudo dos fenômenos que surgem quando se tenta remover a parte móvel da dupla camada elétrica de uma superfície carregada os principais: eletrosmose (movimento de um líquido em relação a uma superfície carregada por efeito de um campo elétrico), potencial de escoamento (o campo elétrico criado quando um líquido flui sobre uma superfície carregada estacionaria), potencial de sedimentação (o campo elétrico criado quando partículas carregadas se movimentam em relação a um líquido estacionário) e eletroforese (movimento de partículas carregadas com os materiais ligadas às mesmas em relação a um líquido estacionário e por efeito de um campo elétrico aplicado); este último é o que apresenta maior aplicação prática.

Como os fenômenos eletrocinéticos relacionam só a natureza da parte móvel da dupla camada elétrica, a forma da dupla camada pode ser descrita em termos de quantidade adimensional "ka", que é a relação entre o raio da curvatura e a espessura da dupla camada. Quando o valor de "ka" é pequeno, uma partícula carregada pode ser considerada como carga pontual, e quando é grande, a dupla camada é aproximadamente plana (Shaw, 1975). 


\section{a) Equação de Huckel: (para “ka” pequeno)}

A Equação (9) é aplicada na eletroforese em meios não aquosos de baixa condutância, como em eletrólitos de $1 \times 10^{-5} \mathrm{~mol} / \mathrm{L}$, para termos de $\mathrm{ka}<0,1$

$$
\mu \mathrm{E}=\frac{\zeta \varepsilon}{1,5 \eta}
$$

Onde $\mu E$ é a mobilidade eletroforética, $\mathcal{E}$ é a permitividade do meio eletrolítico, $\eta$ é a viscosidade do meio (Hiemenz e Rajagopalan, 1997)

\section{b) Equação de Smoluchowski: (para “ka” grande)}

Este modelo, foi desenvolvido para os casos em que o raio da partícula é muito maior que o comprimento de Debye da solução do eletrólito (ka>>1, i.e. $>100$ ). Nesse caso, a superfície da partícula pode ser tomada como plana em relação à espessura da dupla camada. Além disso, assume-se que o fluido escoa paralelamente em relação à superfície, sendo que a velocidade aumenta nos planos mais afastados (Hiemenz e Rajagopalan, 1997).

$$
\mu \mathrm{E}=\frac{\zeta \varepsilon}{\eta}
$$

\section{c) Equação de Henry:}

Henry desenvolveu a Equação (11) eletroforética de caráter geral, aplicável a esferas condutoras e não condutoras:

$$
\mu \mathrm{E}=\frac{\zeta \varepsilon}{1,5 \eta} f(k a)
$$

Onde $f(k a)$ varia de 1,0 para ka pequeno e 1,5 para ka grande. Os valores de potencial zeta calculados com base nas equações de Huckel $(k a=0,5)$ e de Smoluchowski $(\mathrm{ka}=300)$, diferem em cerca de $1 \%$ dos correspondentes valores do potencial zeta calculados com a Equação de Henry.

A Equação de Henry baseia-se em algumas considerações: a aproximação de Debye-Hückel é utilizada, considera-se que o campo elétrico aplicado e o campo elétrico da dupla camada simplesmente se superpõem e se consideram $\varepsilon$ e $\eta$ constantes através de toda a parte móvel da dupla camada (Shaw, 1975).

\subsubsection{Potencial zeta}

É uma medida da estabilidade de um sistema coloidal e indica o potencial necessário para penetrar na camada de íons em torno da partícula para desestabilizá-la como pode ser observado na Figura 5 (Malvern, 2011).

Ao aplicar um campo elétrico tangencial ao longo da superfície carregada, uma força é exercida em ambas partes da dupla camada elétrica. A superfície 
carregada se move na direção do campo elétrico, enquanto que os íons na parte móvel da dupla camada tendem a migrar na direção oposta, gerando um fluxo de solvente e gerando um campo elétrico (potencial zeta), ao movimentar a superfície carregada e a parte difusa da dupla camada (Hiemenz e Rajagopalan, 1997).

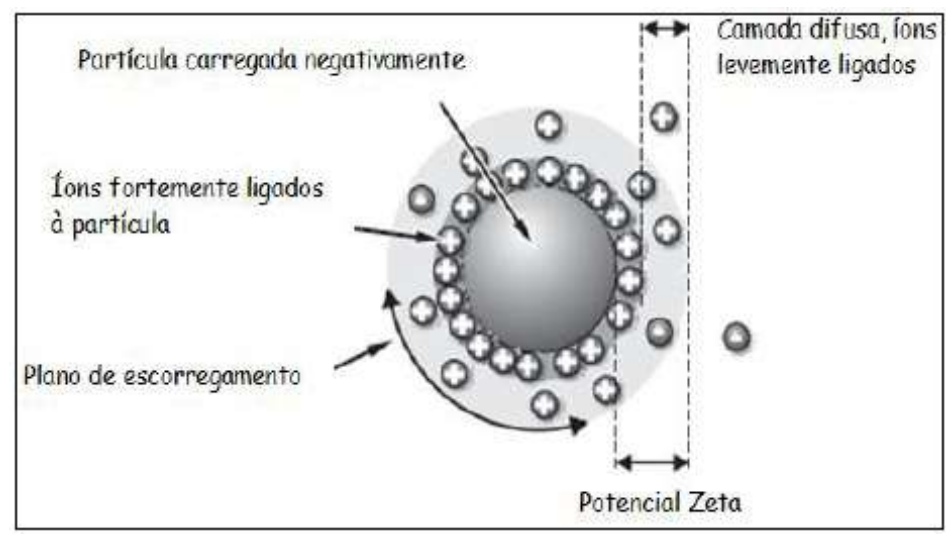

Figura 5 Camada estacionaria do fluído ligada à partícula dispersada (Malvern, 2011)

Se todas as partículas em suspensão têm um potencial zeta negativo ou positivo (maior que $+30 \mathrm{mV}$ e $-30 \mathrm{Mv}$ ), então elas tendem a repelir umas às outros e não haverá tendência para que as partículas consigam se juntar. No entanto, se as partículas possuem baixos valores de potencial zeta, (menor que $30 \mathrm{mV}$ e $-30 \mathrm{mV}$ ) não haverá força para evitar que as partículas se juntem e aconteça uma consequente floculação; quando apresenta um potencial zeta zero, este é chamado de ponto isoelétrico, que é o ponto em que o sistema coloidal é menos estável (Malvern, 2011), como é apresentado na Figura 6.

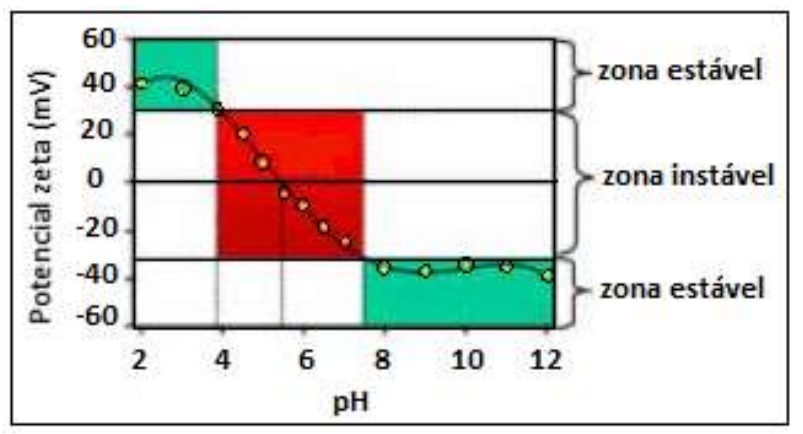

Figura 6 Potencial zeta mostrando a posição do ponto isoeléctrico e os valores de $\mathrm{pH}$ onde a dispersão devería ser estável (Malvern, 2011). 


\subsection{Sistemas coloidais}

A ciência dos colóides se ocupa com sistemas nos quais um ou mais dos componentes apresentam pelo menos uma de suas dimensiones dentro do intervalo de $1 \mathrm{~nm}$ a $1 \mu \mathrm{m}$. Os fatores que mais caracterizam em um sistema coloidal são: as dimensões das partículas, forma e flexibilidade, propriedades (inclusive elétricas), interações partícula-partícula, interações partícula-solvente. Tais propriedades são classificadas por (Shaw, 1975) e (Bohuslav, 1993) conforme características a seguir:

a) Dispersões coloidais: estão termodinamicamente instáveis, por sua elevada energia livre de superfície;

b) Soluções verdadeiras de substâncias macromoleculares (naturais ou sintéticas), estão termodinamicamente estáveis, e são reversíveis após sua separação;

c) Colóides de associação (eletrólitos coloidais), são termodinamicamente estáveis.

Alguns termos de importância dos colóides:

- Interface: A característica de dispersão coloidai é a grande relação área/volume das partículas envolvidas. Nas superfícies de separação (interfaces) entre a fase dispersa e o meio de dispersão, manisfestam-se fenômenos de superfície tais como efeitos de adsorção e dupla camada elétrica.

- Sistemas hidrofílicos e hidrofóbicos: O termo hidrófobo descreve dispersões líquidas de partículas sólidas ou líquidas produzidas por processos mecânicos ou químicos que não têm afinidade com o meio aquoso e o hidrófilo as partículas apresentam afinidade com o meio de dispersão.

- Solvatação: As partículas coloidais são solvatadas com uma camada molecular de solvente, e esse solvente ligado à partícula faz parte dela. Em soluções de longas cadeias de polímero podem interligar-se, por processos físicos ou químicos, e ou emaranhar-se mecanicamente formando uma estrutura reticular tridimensional contínua. Se todo o solvente for retido, o sistema adquire o aspecto de um sólido, e é chamado de gel (Shaw, 1975).

Os movimentos relacionados com as rotações Brownianas das partículas dispersas ou os seus agregados (interação entre a barreira de energia e as partículas), estão relacionados com base nos fenômenos pericinéticos, e os fenômenos ortocinéticos estão relacionados com movimentos causados pelo fluxo do meio da agitação gerada, e dos tamanhos dos agregados maiores do que $1 \mu \mathrm{m}$ (Bohuslav, 1993) e (Wang et al., 2014). 
No presente estudo se avaliará o comportamento dos colóides presentes em rejeitos minerais, sendo a grande maioria composta por minerais filossilicatos, ricos em argilominerais, os quais apresentam estrutura cristalina composta por folhas tetraédricas de silício e oxigênio. Por exemplo, a caulinita está estruturada como unidades de repetição de uma folha octaédrica de alumínio-hidroxila ligado à uma folha tetraédrica de silício-oxigênio, como é ilustrado na Figura 7. Para o caso da montmorillonite e ilita, a folha do octaedro Al-OH é posicionada entre duas folhas de Si-O tetraédricos. As argilas têm uma grande área de superfície com relação ao volume, facilitando uma variedade de interações com espécies iônicas presentes em meio aquoso (Wang et al., 2014).

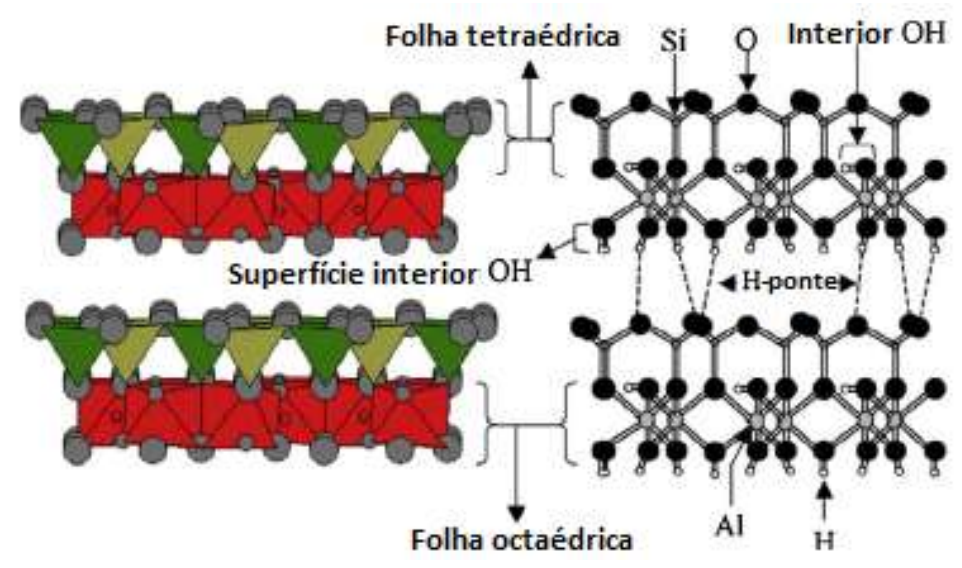

Figura 7 Estrutura de duas camadas da caulinita (Wang et al., 2014).

Partículas sólidas presentes em uma suspensão ou polpa estão sujeitas a sedimentação gravitacional; a lei de Stokes (Equação 12) apresenta as suspensões diluídas, a velocidade de sedimentação é proporcional ao diâmetro da partícula:

$$
v=\frac{\operatorname{gD}^{2}\left(\rho_{1}-\rho_{2}\right)}{18 \mu}
$$

onde g é a força do campo gravitacional, D é o tamanho de partícula característica, $\rho_{1}$ a densidade da partícula, $\rho_{2}$ a densidade do fluido, e $\mu$ a viscosidade da polpa.

Considerando a relação apresentada por Stokes, tem-se que partículas na fração areia sedimentam mais rápido do que siltes e argilas. 


\subsubsection{Estabilidade de colóides: (Teoria DLVO)}

A força de atração entre partículas coloidais tem sua origem nas forças de van der Waals, que é o resultado das forças entre as moléculas individuais de cada colóide (Figura 8). As moléculas de água, que possuem um momento dipolar permanente, se atraem umas com as outras fortemente porque os dipolos tendem a se alinhar, e por serem mais atraentes do que repulsivos, permitem reduzir a energia livre do sistema.

Quando existem forças de natureza elétrica ou estérica suficientes para contrabalancear essa força atrativa, o sistema pode adquirir estabilidade e as partículas mantêm-se dispersas.

A repulsão eletrostática se origina quando as partículas dos colóides se aproximam na dupla camada, fazendo-se necessária uma quantidade de energia para superar essa força de repulsão para a atração entre as partículas (Figura 8), e atinge um valor máximo, o qual está relacionado com o potencial de superfície $\Psi_{0}$, diminuindo a energia de repulsão fora da camada dupla (Malvern, 2011).

A teoria DLVO (Derjaguin e Landau, Verwey e Overbeek) explica a tendência da aglomeração ou dispersão de colóides, devido à combinação das forças de Van der Waals, que resulta em uma energia líquida de interação (Figura 8). Se há uma zona de repulsão, então, o ponto de máxima energia repulsiva é chamado de barreira de energia, a altura dessa barreira indica quão estável é o sistema (Malvern, 2011).

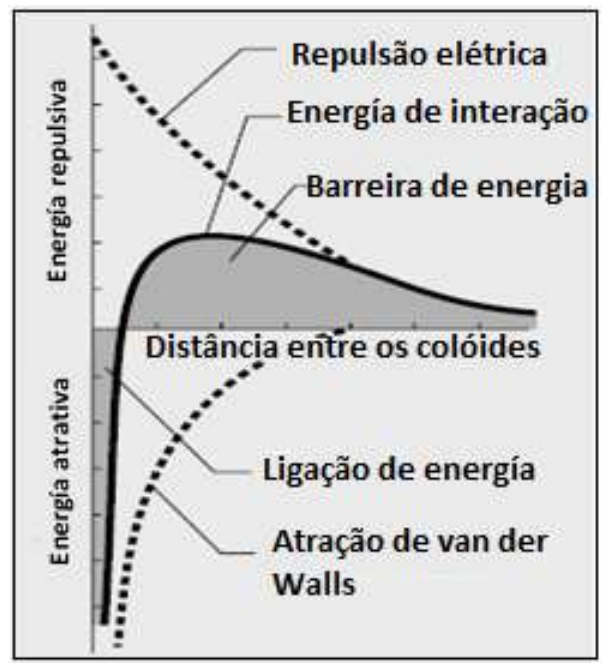

Figura 8 Teoria de DLVO, (Malvern, 2011)

A energia potencial de interação, que é a contribuição das energias atrativas e repulsivas, é quantitativamente determinada pela relação: (Hunter, 1993). 


$$
V_{A}=\frac{-\mathrm{Aa}}{12 H}
$$

onde $H$ é a distância entre as partículas, a o raio da partícula e $A$ a constante de Hamaker, cujo valor depende da natureza química das fases dispersa e contínua, e é um fator determinante da intensidade do potencial atrativo entre as partículas.

A constante de Hamaker é determinada por:

$$
A=\left(\frac{\rho N_{A} \pi}{M}\right)^{2} \beta
$$

Onde $\rho$ é a densidade da partícula, $N_{A}$ é o número de Avogrado, Mé a massa molar do sólido e $\beta$ um parâmetro de interação entre as partículas (inclui valores de momento de dipolo, polarizabilidade, freqüência de vibração eletrônica, etc.) que pode ser obtido na literatura (Hunter, 1993).

O potencial de superfície $\left(\Psi_{0}\right)$ tem grande influência no diagrama DLVO, já que quanto maior o seu valor, maior a repulsão entre as partículas. A concentração de eletrólito e a valência do mesmo, determinantes do parâmetro $k$, também são fatores que afetam fortemente a energia de interação entre as partículas. $O$ aumento da força iônica através da variação desses parâmetros leva à diminuição da energia da barreira de repulsão e à consequente coagulação das partículas (Bohuslav, 1993).

\subsection{Coagulação e floculação}

\subsubsection{Introdução}

Os processos de agregação e floculação na solução são denominados processos de adsorção. A adsorção tem lugar entre uma solução líquida em uma fase de limite plano formado por esta solução, com um sólido ou fase fluida. Assumindo um sistema termodinâmico consistindo só da solução da superfície, com temperatura e pressão uniformes em todo o sistema. A desestabilização dos colóides em sistemas aquosos por polieletrólitos é preciso considerar os seguintes aspectos, conforme reportados por (Bohuslav, 1993):

> Sua adsorção melhora ajustando a concentração de sais e o pH. Assim, ao incrementar a força iônica, é possível decrescer a repulsão entre os segmentos da molécula polimérica e, consequentemente, sua solubilização no meio;

> Para a formação de pontes com o polímero, e com curtas e poucas caudas, precisam de uma aproximação estreita das superfícies antes de serem adsorvidas; 
$>$ A carga de superfície livre gera uma força repulsiva eletrostática. Isto pode também ser o caso de polímeros não carregados, quando são frequentemente utilizados em solventes não aquosos;

há uma competição por sítios de superfície entre os segmentos de polímero adsorventes e os íons solúveis, especialmente em elevadas concentrações de sais.

Uma barreira de potencial entre o polímero adsorvido e a solução podem estar presentes, isso acontece quando a força iônica é muito baixa.

\subsubsection{Floculação}

A floculação é uma etapa essencial em muitos processos de separação sólido-líquido, sobretudo em operações de desaguamento industrial (espessamento e filtragem) e no tratamento de águas residuais, quando as partículas sólidas são muito pequenas para serem naturalmente separadas por gravidade. Os parâmetros de separação são, em grande parte, determinados pelas propriedades dos flocos formados em agitação controlada.

A eficácia dos processos de floculação, a velocidade de formação de flocos, assim como a distribuição de tamanho, a densidade, ou a força dos agregados, depende principalmente da interação entre as partículas sólidas e das forças hidrodinâmicas que derivam do movimento do fluido. Os gradientes de velocidade ou turbulência no seio da suspensão não só transportam as partículas, mas também auxiliam na formação e/ou quebra dos agregados. Assim, um floco pode ser estável até um determinado tamanho e, a partir dali o seu crescimento poderá ocasionar a sua ruptura, dependendo das condições hidrodinâmicas e dos parâmetros físico-químicos do meio.

A força de coesão de um floco ou agregado depende diretamente das forças de adesão entre partículas primárias e da resistência dos flocos à tensão hidrodinâmica de escoamento, sendo geralmente determinada pelo tipo de agente floculante utilizado. A agregação de sólidos dispersos pode ser iniciada por diferentes mecanismos de desestabilização (Bohuslav, 1993):

- coagulação: atração interparticulas como consequência da compressão da dupla camada ou adsorção específica de um contra-íon;

- coagulação de varredura: quando uma partícula é capturada mecanicamente para a estrutura de precipitados $\mathrm{Al}(\mathrm{OH})_{3}$;

- carga de conexão: floculação com polieletrólitos altamente carregados e de massa molar relativamente baixo (ex.: ácidos húmicos) e 
- por pontes de floculação com polímeros de elevada massa molar (ex.: quitosana).

A eficácia de floculantes na adesão de partículas ou na estabilidade dos flocos, além da concentração do polímero e das condições hidrodinâmicas, depende de outras variáveis químicos, que serão apresentadas e discutidas nas seções a seguir.

\subsubsection{Interação polímero com partícula}

Quando os polímeros em solução se acumulam em uma interface é porque seus segmentos têm uma afinidade maior com os sítios de superfície do que pelo solvente. E é conhecido como adsorção (Bohuslav, 1993).

Quando concentração do polímero é elevada, todas as partículas estarão cobertas por uma camada de polímero relativamente densa. Quando duas dessas partículas cobertas pelo polímero se aproximam uma da outra, a interpenetração das camadas de polímero leva à chamada estabilização estérica. Nessa situação, os sistemas coloidais podem ser estáveis sob condições onde tem-se ausência da floculação do polímero. Assim, dependendo das condições, a adsorção de polímero pode causar uma interação atrativa (ponte de floculação) ou repulsão (estabilização estérica) (Bohuslav, 1993; Hunter, 1993).

O esgotamento do polímero só induz a atração de colóides, o que pode resultar na desestabilização. Este efeito é normalmente referido como esgotamento de floculação (Bohuslav, 1993).

Um polímero pode adsorver-se na superfície de uma partícula coloidal como um resultado de uma interação Coulombiana (carga-carga), interações dipolodipolo, pontes de hidrogênio, forças de van der Waals, ou uma combinação qualquer dessas forças.

O resultado são alguns segmentos ligados à superfície (como trens) separados uns dos outros por alças que se estendem para dentro da solução e que terminam com uma cauda (geralmente muito estendida) em cada extremidade do cadeia polimérica, como mostrado na Figura 9. Quando duas partículas estão unidas, torna-se possível para as alças e as caudas de um polímero juntar-se com uma conexão livre na superfície das partículas para formar pontes. Considera-se que a concentração ótima de polímero para promover uma floculação eficiente é aquela capaz de recobrir, pelo menos, metade da superfície das partículas presentes no meio (Hunter, 1993). 
Na maioria dos sistemas experimentais o polímero é polidisperso, com uma distribuição de comprimento de cadeia larga. A característica mais importante é que, em soluções não muito concentradas as longas cadeias conseguem se adsorver preferencialmente, em relação às mais curtas. Assim, com o aumento da dosagem do polímero as pequenas moléculas são deslocados pelas grandes (Bohuslav, 1993).

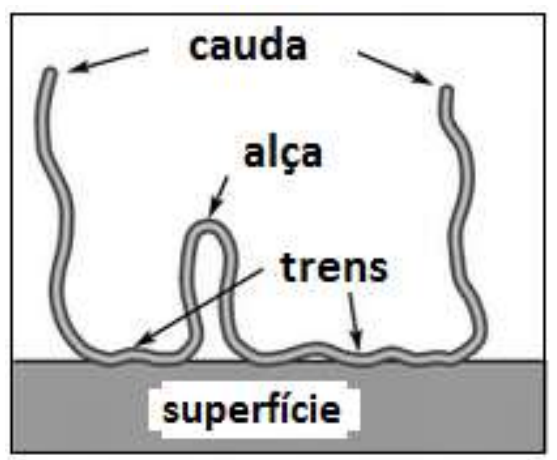

Figura 9 Forma de adsorção do polímero na partícula (Bohuslav, 1993)

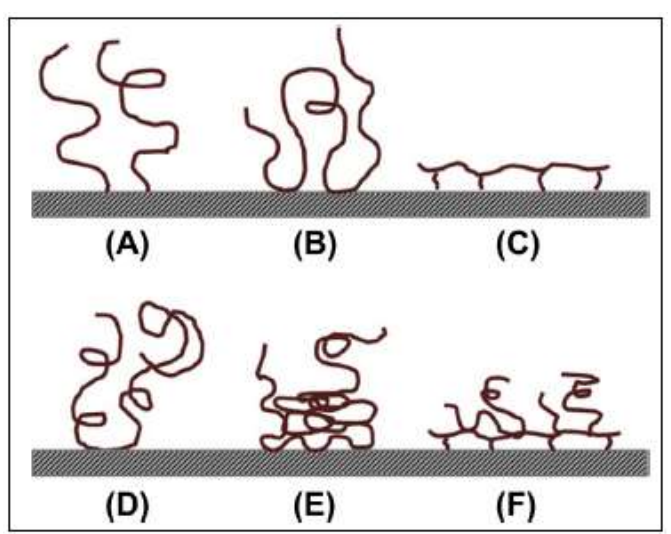

Figura 10 Diferentes tipos de conformação do polímero adsorvido nas partículas (Wang et al., 2014)

Interação polímero-sólido: a forte atração irá resultar no colapso do polímero sobre a superfície sólida (Figura $10(\mathrm{C})$ e (F)), e com fraca atração do polímero se estenderá para fora a partir de seus pontos de ancoragem, como mostrado nos casos (A), (B) e (D) da Figura 10. 
Interação polímero-água: A forte afinidade com a água irá incentivar que a cadeia do polímero maximize a sua área de contacto com a água, resultando em conformações de "escovas" do polímero (por exemplo, nos casos A, B, e D); os polímeros relativamente hidrofóbicos, por outro lado, minimizaram sua área de contato com a água, resultando em conformações de "fungos", como visualizado em $(F)$.

Auto-interação do polímero: a atração excessiva entre os grupos funcionais

na cadeia polimérica irá favorecer o auto-colapso e a formação de caudas e alças (por exemplo, Figura 10 (E)).

Rigidez na cadeia do polímero: os polímeros rígidos, tais como polímeros altamente carregados, são mais resistentes a mudanças em suas conformações (Figuras $10(A)$ e (C)).

Durante o processo de floculação, os sólidos são entrelaçados através da formação de pontes permanentes entre as partículas por substâncias macromoleculares, que são conhecidas como agentes de aglomeração.

Os agentes de aglomeração são subdivididos em seis categorias, como é mostrada da Figura 11, com a adição de eletrólitos elementares facilita a coagulação não específica das suspensões,como é apresentado nas Figura 11 (a) e (b), a adsorção superficial das camadas dos polieletrólitos de cadeia curta e carga oposta pode levar à coagulação. Caso o polieletrólito somente seja adsorvido em partes da superfície como na Figura 11 (c), então a atração eletrostática pode ainda permitir a coagulação (modelo conexão eletrostática).

Ao contrário da adsorção superficial das partículas, com uma massa molar elevada de carga oposta, o polímero pode ser depositado sobre as alças e caudas e flocular, como é mostrado nas Figuras 11 (d) e (e). O tamanho dos polímeros pode exceder a faixa efetiva da repulsão eletrostática. Finalmente, na Figura 11 (f) se ilustra como as partículas podem ser ligadas por redes de gel intermoleculares (Bohuslav, 1993). 


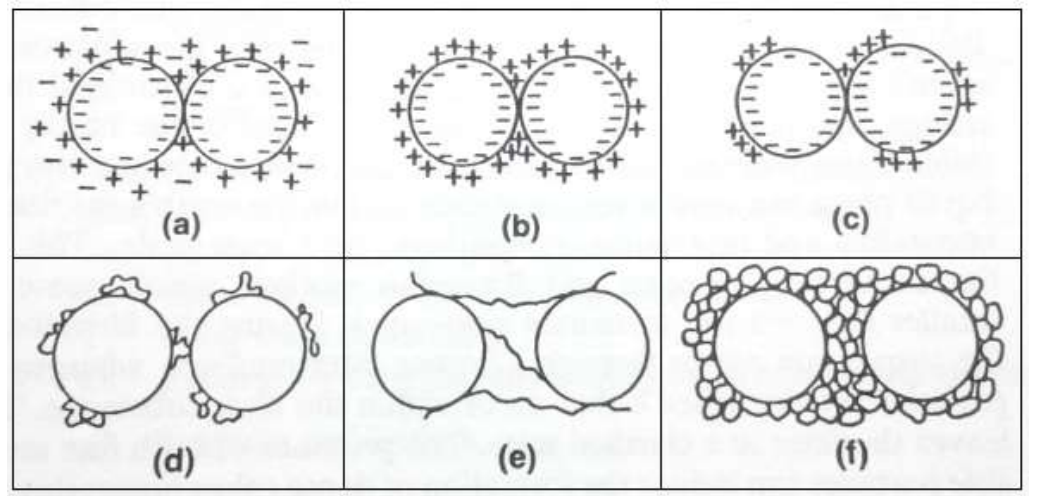

Figura 11 Diferentes mecanismos de aglomeração (Bohuslav, 1993)

O critério para uma ótima remoção de sólidos finos a partir de suspensões aquosas é capturar rapidamente os finos. Com base nas observações descritas, as condições para atingir esse objetivo são descritas a seguir:

$>$ As interações entre o polímero e os sólidos devem ser fracamente atraentes, uma vez que a estabilização estérica possa acontecer; os polímeros são fortemente atraídos e cobrem integralmente os sólidos.

> A forte repulsão entre o polímero e os sólidos, por outro lado, reduz drasticamente a eficiência de colisão entre os sólidos e polímeros.

$>$ Em soluções aquosas, o floculante deve ter algum grau de natureza hidrofílica para que sua extensão em fase aquosa sob a forma de alças seja favorável.

> A extensão de auto-interação deve ser minimizada, a fim de promover mais pontos de contacto para a captura dos sólidos.

A eficácia de floculantes na adesão de partículas ou estabilidade dos flocos, além da concentração do polímero e das condições hidrodinâmicas, dependem de outras variáveis químicas, tais como:

\subsubsection{Efeito da adesão e adsorção das partículas}

O tipo de interacção depende tanto da concentração do polímero quanto do número de colisões de partículas por unidade de tempo (determinado pela concentração de partículas e intensidade de fluxo), conforme reportado por (Bohuslav, 1993).

Uma comparação da interação da energia de van der Waals com as pontes de hidrogênio ou ligação química responsável pela adsorção do polímero 
apresenta as forças de adesão devem ser uma ou duas ordens de grandeza maior do que as forças de atração provocadas pela interação interpartículas. Esta relação pode ser observada experimentalmente com relação ao tamanho dos flocos. Para determinar a estabilidade dos flocos, a força de adesão entre duas esferas $d_{1}$ e $d_{2}$ pode ser calculada a partir da Equação:

$$
F_{\mathrm{a}}=\pi(\Delta \mathrm{g}) \frac{\mathrm{d}_{1} \mathrm{~d}_{2}}{\left(d_{1}+d_{2}\right)}
$$

Onde

$$
\Delta \mathrm{g}=\mathrm{g}\left(\mathrm{h}_{\mathrm{o}}\right)-\mathrm{g}(\mathrm{h}=\infty)
$$

é a mudança de energia livre ( $\mathrm{g}$ ) do sistema relacionada com a unidade de área quando as partículas aderentes da distância do contato $h_{0}$ para uma distância de $\mathrm{h}=\infty$. Então a força de adesão será determinada pela energia requerida para dessorver os trens de ligação a partir de superfícies sólidas.

Assim, além do tipo de interação polímero /superfície (ponte de hidrogênio, ação eletrostática, ligações químicas), a distribuição de densidade de cargas através das interfaces adjacentes é um fator importante que determina a força de adesão.

Os movimentos fluidos influenciam não apenas na conformação do polímero na solução ou na camada de adsorção, mas também a adesão de equilíbrio da partícula. Os fenômenos de fortalecimento observados são atribuídos às mudanças estruturais das moléculas. Assim, o estado de equilíbrio de conformação dos flocos do polímero pode ser obtido em um curto intervalo de tempo e as propriedades dos flocos podem ser melhoradas pela aplicação apropriada das forças hidrodinâmicas (Bohuslav, 1993).

\subsubsection{Efeito da concentração do polímero}

Depois de misturar uma suspensão com a solução polimérica existem várias possibilidades da interação das partículas com o polímero, conforme apresentado na Figura 12. Quando se tem baixa concentração do polímero, a taxa de adsorção é pequena em comparação com a freqüência de colisão das partículas e, assim, o a floculação pode ocorrer por adsorção em mais de uma partícula (Hiemenz e Rajagopalan, 1997).

Em alta força iônica e alto potencial da dupla camada, devido à grande repulsão eletrostática, forma-se uma barreira de energia, dificultando a adsorção 
do polímero nas partículas, bem como impedindo a aproximação das mesmas, conforme relatado nos trabalhos de Bohuslav (1993) e Hiemenz; Rajagopalan (1997).

Em uma concentração média do polímero, podem acontecer dois tipos de interação: a estabilização estérica, devido ao total recobrimento da partícula, impossibilitando a sua floculação; o outro tipo de interação ocorre quando forças de adesão das partículas de maior tamanho se sobrepõem às forças de adsorção polímero-partícula, fazendo com que boa parte do polímero permaneça livre em solução, sem ser adsorvido (Hiemenz e Rajagopalan, 1997); esse tipo de interação é conhecido como floculação por depleção ou adosrção negativa do polímero (Baltar, 2010).

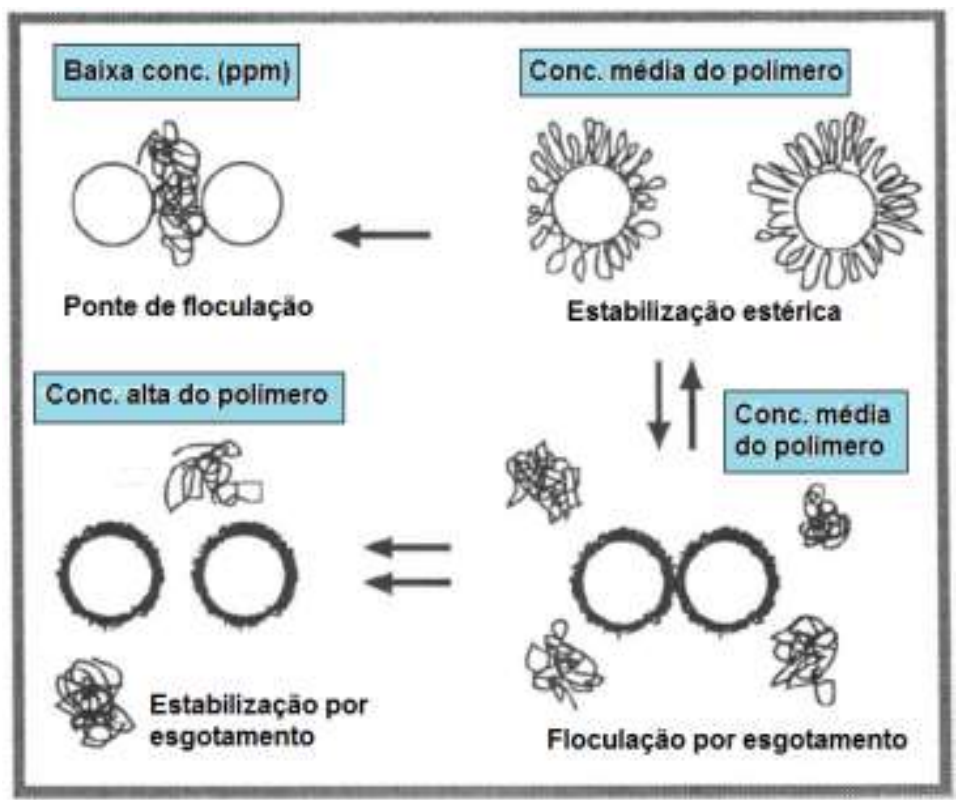

Figura 12 Diferentes possibilidades de interação polímero-partícula na solução (Hiemenz e Rajagopalan, 1997)

\subsubsection{Efeito dos contraíons}

A magnitude da repulsão de potencial eletrostático pode ser significativamente manipulada pela adição de agentes de agregação.

A maioria das partículas em soluções aquosas possui carga de superfície negativa e sua força pode ser reduzida pela adsorção específica de contra-íons determinantes de potencial, a qual geralmente só é possível com a modificação do $\mathrm{pH}$ do meio. No caso da coagulação não específica, a adição de um eletrólito aumenta a força iônica dos contra-íons na suspensão, reduzindo, portanto, a faixa 
efetiva de repulsão eletrostática. Muitas vezes, a presença de íons de cálcio e magnésio como constituintes da água natural já é suficiente para iniciar a coagulação das partículas mais finas (Hunter, 1993). Segundo (Bohuslav, 1993), a presença desses íons promove a diminuição da dupla camada difusa em torno das partículas, que é um processo conhecido como compressão da dupla camada.

\subsubsection{Efeito de colisão das partículas com o polímero}

Os tempos médios entre a colisão polímero-partícula e partícula-partícula determinam o tempo disponível de uma molécula adsorvida para relaxar-se, a partir de um "novelo de lã" para uma conformação esticada. Se a concentração de partículas é alta, a taxa de colisão entre as partículas é elevada e a molécula do polímero ligado não tem oportunidade de estender-se.

Em concentrações de partículas mais baixas, a taxa de colisão é lenta, e a molécula do polímero se relaxa e perde a sua capacidade de ponte, especialmente se alguma repulsão da camada ainda puder acontecer. A Figura 13 ilustra os mecanismos de floculação para que um polímero mude de uma conformação inativa a uma conformação ativa, conforme apresentado por (Bohuslav, 1993) e por (Bolto e Gregory, 2007).

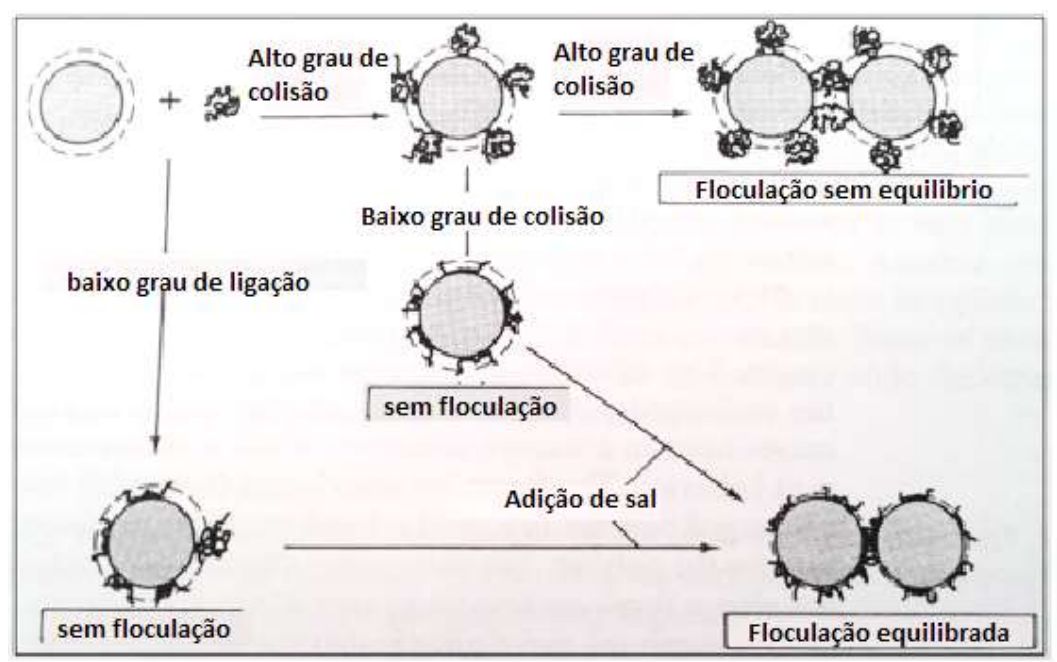

Figura 13 Mecanismos de pontes de floculação (Bohuslav, 1993)

\subsubsection{Efeito da heterocoagulação}

Nos argilominerais, a origem das cargas negativas ocorre nas faces do plano de ruptura desses cristais Figura 14 (a). Na caulinita, quando as folhas se quebram por moagem, por exemplo, ocorre a exposição dos átomos de alumínio 
ligados aos átomos de oxigênio e, em meio ácido, estes podem aceitar um próton para gerar uma carga positiva sobre a borda da rede cristalina:

$$
-\mathrm{Al}-\mathrm{O}-\mathrm{Al}+\mathrm{H}^{+} \longrightarrow-\mathrm{Al}-\mathrm{OH}^{+}-\mathrm{Al}
$$

Em condições ácidas diluídas $(4 \leq \mathrm{pH} \leq 6)$, as partículas podem assossiarse em estruturas abertas como castelo de cartas (house of cards) - Figura 14 (b) - que se abrem gradualmente para fora quando o pH é elevado e as cargas positivas nas bordas neutralizam-se. Com o pH elevado as partículas de argila pode coagular apenas se a concentração de sal é elevada o suficiente para reduzir a repulsão entre as cargas das caras. A interação entre as superfícies, tendo significativamente diferentes estados de carga, é chamado de heterocoagulação (Hunter, 1993).

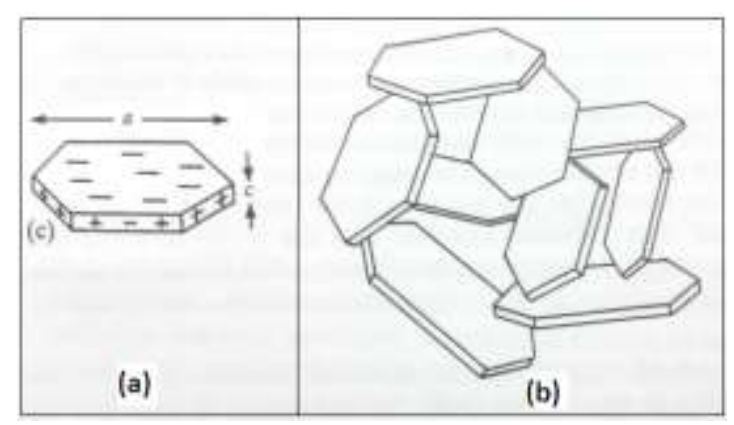

Figura 14 a) Estrutura de um cristal da caolinita, b) Associação dos cristais da caulinita (Hunter, 1993)

Partículas sólidas finas, em especial as argilas, quando estão dispersas num fluido aquoso podem adquirir carga de superfície através de uma variedade de mecanismos isomorfos de substituição, onde os cátions estruturais (por exemplo, $\mathrm{Si}^{4+}, \mathrm{Al}^{3+}$ ) são trocados por cátions dissolvidos de igual ou, de uma valência inferior (por exemplo, $\mathrm{Al}^{3+}, \mathrm{Mg}^{2+}$, e $\mathrm{K}^{+}$), resultando em uma carga líquida negativa sobre as caras da partícula de argila (Wang et al., 2014).

Pequenas quantidades de íons de cálcio dispersos na solução com a montmorillonita promovem o contato face a face, e podem estabilizar em formas de bandas, como mostrado na Figura 15 (a), e essas bandas podem formar agregados compactos, como apresentado na Figura 15 (b) (Bohuslav, 1993). 


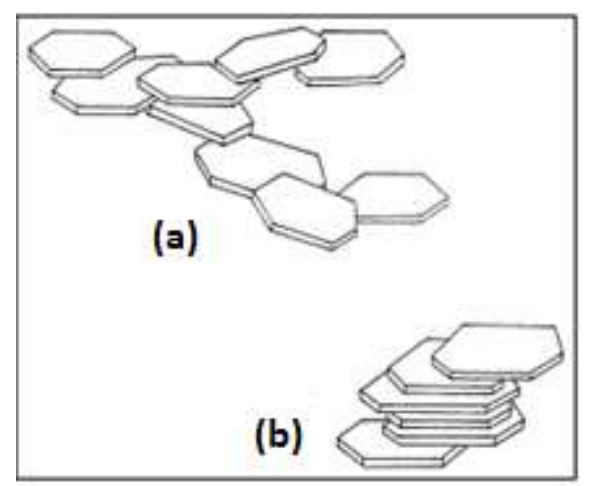

Figura 15 Adsorção da montomorillonita em presença de ions de Ca (a) e (b) (adaptado de Bohuslav, 1993)

\subsubsection{Efeito da massa molar}

As espécies de elevada massa molar são mais propensas a adsorver do que os polímeros de baixa massa molar. A palavra polieletrólito é por vezes utilizada para todos os tipos de polímero que possui elevada carga superficial líquida. Um polímero flexível consegue, muitas vezes, uma carga líquida de grupos carboxilato ou sulfato (-COO-, $\left.-\mathrm{SO}_{4}{ }^{-}\right)$ou de grupos amino $\left(\mathrm{NH}_{4}{ }^{+}\right)$ou compostos de nitrogênio análoga. Os polieletrólitos podem ser classificados como fortes ou fracos, tendo os últimos a carga líquida de superfície variável com o pH.

A dependência da massa molar com a quantidade de partículas adsorvidas dá uma ideia de como o polímero é adsorvido sobre a superfície. A maioria dos polímeros encontrados adsorve numa configuração de "novelo de lã" e a dependência da massa molar adsorvida é proporcional à Ma, onde M é a massa molar do polímero e a é uma constante com um valor na faixa de 0,3-0,5. A Figura 16 apresenta uma dependência da massa molar, neste caso da adsorção do poli (álcool vinílico) em solução aquosa em uma superfície de látex de poliestireno. $\mathrm{O}$ polímero com uma elevada massa molar apresenta uma adsorção maior do que os polímeros com massas molares mais baixas (Holmberg et al., 2002). 


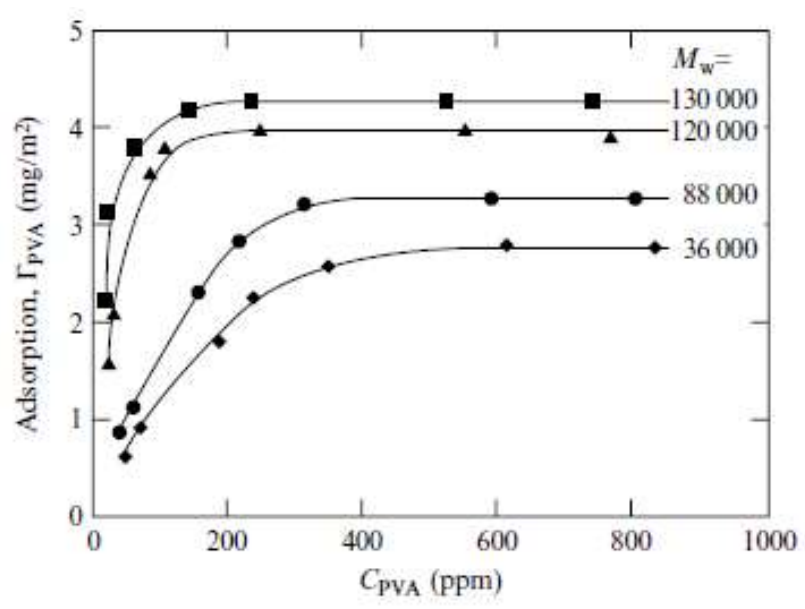

Figura 16 Adsorção do poli (álcool vinílico) em solução aquosa em uma superficie de látex de poliestireno, segundo a massa molar (Holmberg et al., 2002)

A adsorção de compostos de baixa massa molar, como as substâncias húmicas, tende a diminuir quando próximo da concentração de equilíbrio; esta seletividade esta associada à habilidade das moléculas de menor tamanho em acessar, mais rapidamente, os sítios ativos interpartículares.

Quando a densidade de carga de superfície torna-se mais negativa, no progresso de adsorção forma-se uma barreira repulsiva na interface. Como resultado, os componentes poliméricos de elevada massa molar são impedidos de se aproximar da superfície do mineral. Os componentes de alta massa molar das sustâncias húmicas são preferencialmente adsorvidos em argilas e sais minerais. Em força iônica elevada $(>0,1 \mathrm{M}$ de $\mathrm{NaCl})$ ou de alta acidez $(\mathrm{pH}<4)$, apresentam afinidade soluto-superfície relativamente alta (Theng, 2012).

\subsection{Polímeros naturais na adsorção em argilominerais}

\subsubsection{Introdução}

A capacidade dos argilominerais em adsorver o ácido húmico é influenciada pela conformação molecular, área de superfície, accesibilidade do poro, condições de $\mathrm{pH}$ e força iônica. As interações das pontes de hidrogênio e as forças de van der Waals na adsorção dão uma contribuição muito forte na ligação com as moléculas do $\mathrm{AH}$, para atingir uma irreversibilidade na adsorção. Em baixas concentrações do polímero, asmoléculas adotam uma conformação esticada, o que facilita a sua movimentação e entrada nos poros da partícula, reduzindo a 
possibilidade de ocorrência de obstrução física ou impedimento estérico. A adsorção do ácido húmico por diferentes filossilicatos diminuiu na ordem de caulinita>illita>clorita (Theng, 2012).

Para um grupo de minerais, tais como os silicatos, a estabilidade estrutural em um ataque ácido é determinada pela natureza do íon metálico. Isto é porque a ligação metal-oxigênio (M-O) é fraca e mais sucetível do que a ligação Si-O (Theng, 2012).

As condições existentes em meio ácido permitem a formação de cargas positivas na borda dos argilominerais, enquanto na estrutura basal ocorre a liberação de cátions de coordenação $\left(\mathrm{Al}^{+3}, \mathrm{Fe}^{+3}, \mathrm{Mg}^{+2}\right)$ das camadas mais internas dessa estrutura (Komadel e Madejová, 2006).

No presente estudo está sendo avaliado a aplicação dos polímeros naturais como a quitosana e o ácido húmico na adsorção de partículas em polpas minerais, atualmente está sendo utilizado na maioría dos casos as poliacrilamidas (PAM), que são polímeros sintéticos, a continuação é apresentada uma tabela comparativa destes polímeros mencionados:

Tabela 3 Comparação dos polímeros naturais com os polímeros sintéticos

\begin{tabular}{|c|c|}
\hline Polímeros naturais & Polimeros sintéticos \\
\hline $\begin{array}{l}\text { - São extraídos de fontes } \\
\text { naturais. }\end{array}$ & $\begin{array}{ll}\text { - São sintetizados } \\
\text { quimicamente. }\end{array}$ \\
\hline $\begin{array}{ll}- & \text { Apresentam uma massa } \\
& \text { molar }<300 \mathrm{KDa}\end{array}$ & $\begin{array}{ll}\text { - } & \text { Apresentam uma massa } \\
& \text { molar }>300 \mathrm{KDa}\end{array}$ \\
\hline $\begin{array}{l}\text { - Adsorvem as partículas } \\
\text { em pH's específicos. }\end{array}$ & $\begin{array}{l}\text { - Adsorvem as partículas } \\
\text { em uma faixa de } \mathrm{pH} \\
\text { ampla. }\end{array}$ \\
\hline 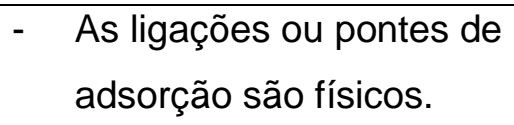 & $\begin{array}{l}\text { - As ligações ou pontes de } \\
\text { adsorção são químicos. }\end{array}$ \\
\hline - São biodegradáveis. & Não são biodegradáveis. \\
\hline
\end{tabular}

\subsubsection{Propiedades da quitosana}

A quitina, poli (B- (1-4) -N-acetil-D-glucosamina) é um polissacarídeo natural e é o biopolímero mais abundante produzido, depois da celulose. É extraído de fontes como crustáceos marinhos, camarões e caranguejos. A quitina ocorre na 
natureza como microfibrilas cristalinas ordenadas, formando componentes estruturais no exo-esqueleto de artrópodes ou nas paredes celulares de fungos e leveduras.

A quitosana (Figura 17) é o derivado mais importante de quitina; quando o seu grau de desacetilação atinge cerca de $50 \%$ (dependendo da origem do polímero), torna-se solúvel em soluções aquosas ácidas, por meo da protonação da função $-\mathrm{NH}_{2}$ no C-2, que é a posição da unidade de repetição de D-glicosamina, polissacárideo que é convertido a um polieletrólito em meio ácido.

A quitosana é o único polímero catiônico pseudonatural, com inúmeras aplicações (floculante para recuperação de proteína, a despoluição, etc). É solúvel em meio aquoso ácido, sendo utilizado em muitas aplicações, como nas indústrias de alimentos, cosméticos, biomédicos e aplicações farmacêuticas (Rinaudo, 2006).

A quitosana é um polímero biodegradável, com aplicação na floculação de lamas em estações de tratamento de água (Bratskaya, Schwarz e Chervonetsky, 2004).

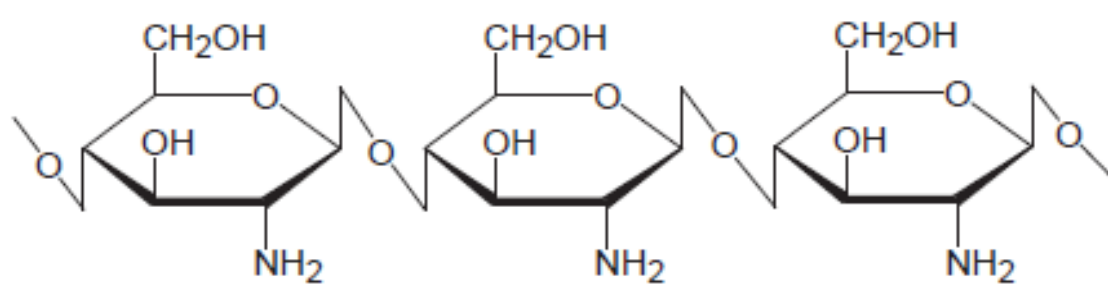

Quitosana

Figura 17 Estrutura da quitosana (poli (D-glucosamina), (Bratskaya, Schwarz e Chervonetsky, 2004)

\subsubsection{Solubilidade da quitosana}

As propriedades das soluções da quitosana dependem, não só da sua média de desacetilação, mas também da distribuição dos grupos acetil ao longo da cadeia principal e de sua massa molar. A solubilização da quitosana apresenta um grau médio de ionização de $\alpha=0,5$ em presença de $\mathrm{HCl}$, que corresponde a um valor de $4,5 \leq \mathrm{pH} \leq 5$. São diretamente solúveis em água, produzindo uma solução ácida com $\mathrm{pK}_{0}=6$ e um grau de protonação de $\alpha=0$. Assim, a quitosana é solúvel em pH inferior a 6 (Rinaudo, 2006) 
Em pH superiores a 6 a quitosana é insolúvel e desprotonada, então a floculação ocorre devido ao mecanismo de floculação por pontes (Bratskaya, Schwarz e Chervonetsky, 2004).

É importante também considerar as ligações de ponte de hidrogênio dentro da cadeia que envolve os grupos hidroxila. A distribuição dos grupos acetil ao longo da cadeia pode influenciar na solubilidade do polímero, nas interações intercadeias devido a ligações por ponte de hidrogênio e nas interações de caráter hidrofóbico do grupo acetil (Rinaudo, 2006).

\subsubsection{Interação da quitosana com argilominerais}

A quitosana é conhecida por ter uma boa capacidade de complexação dos grupos $-\mathrm{NH}_{2}$ da cadeia, promovendo interações específicas com metais, especialmente em partículas muito finas. A natureza do cátion é muito importante no mecanismo de interação e a afinidade da quitosana na adsorção de cátions é mostrada a seguir (Rinaudo, 2006):

$\mathrm{Cu}^{+2} \gg \mathrm{Hg}^{+2}>\mathrm{Zn}^{+2}>\mathrm{Cd}^{+2}>\mathrm{Ni}^{+2}>\mathrm{Co}^{+2} \sim \mathrm{Ca}^{+2}>\mathrm{Eur}^{+3}>\mathrm{Nd}^{+3}>\mathrm{Cr}^{+3} \sim \mathrm{Pr}^{+3}$

Estudos da adsorção de quitosana em argilominerais como a caulinita foram realizadas por Li et al., (2013), que verificaram a dependência da adsorção com a densidade de carga; quanto maior a densidade de carga, mais fortes são as interações eletrostáticas entre quitosana e as partículas negativas da caulinita. Quando a densidade de carga de quitosana é baixa, o polímero apresenta menos pontos de contato com os locais negativamente carregados da superfície da caulinita. Portanto, a densidade de carga é dependente de sua protonação; a maioria dos grupos amina está protonada abaixo do valor de pKa, que é próximo de 6,5. Assim, mais de $90 \%$ dos grupos amina foram protonados em $\mathrm{pH} 5$ e desprotonados em valores de $\mathrm{pH}$ acima de 9 , o que significa que nesse $\mathrm{pH}$ não será possível a neutralização de cargas coloidais negativas pela quitosana. 


\subsubsection{Breve descrisão sobre os diferentes AH’s envolvidos}

\subsubsection{AH da SigmaAldrich}

O ácido húmico da SigmaAldrich, possui grande capacidade de complexação com metais pesados. A sal de sódio do ácido húmico actua como um substituto para as substâncias húmicas, que atua muito bem em isolar os componentes da matéria orgânica no aerossol atmosférico (Sigma-Aldrich, 2016).

\subsubsection{AH do carvão mineral}

Carvão mineral é definido, segundo World Coal Institute, como uma rocha sedimentar orgânica e combustível, que é composta principalmente por carbono, hidrogênio e oxigênio.

É classificado de acordo com a sua qualidade em: turfa, de baixo conteúdo carbonífero, que constitui um dos primeiros estágios do carvão com teor de carbono na ordem de 45\%; linhito, que apresenta teor de carbono variando entre 60 e 75\%; carvão betuminoso (hulha), o mais utilizado como combustível, e que contém entre 75 e $85 \%$ de carbono e antracito, o mais puro dos carvões, que apresenta teor de carbono superior a $90 \%$. (Garces, 2015)

\subsubsection{AH do coque mineral}

O coque mineral é oriundo de processos de beneficiamento de certos tipos de carvão mineral, conhecido como coqueificação. Para ser utilizado na produção de coque o carvão mineral deve possuir certas propriedades físicas para que, quando aquecido em ausência de ar, ele amoleça, inche, aglomere e, finalmente, solidifique como um sólido poroso e rico em carbono. O carvão coqueificável deve também apresentar baixos teores de enxofre e fósforo.

A coqueificação consiste basicamente no aquecimento do carvão, em ausência de ar, até cerca de $1100^{\circ} \mathrm{C}$. À medida que é aquecida, a carga sólida passa por duas fases distintas, uma plástica (até $450^{\circ} \mathrm{C}$ ) e uma de ressolidificação, a partir de $450^{\circ} \mathrm{C}$.

A coqueria convencional é utilizada em todas as usinas siderúrgicas do Brasil. Esse tipo de beneficiamento possibilita a recuperação de subprodutos (óleos leves, gás de coqueria, alcatrão). (Andrade, 2014) 


\subsubsection{AH do Suwanne River (IHSS)}

O rio Suwannee nasce no pântano de Okefenokee em Geórgia sul e flui ao sudoeste do Golfo do México. O pântano de Okefenokee contém extensos depósitos de turfa; No entanto, a decomposição vegetal fornece a maior parte do carbono orgânico dissolvido (COD), nas águas. Em suas cabeceiras no pântano de Okefenokee, o rio Suwannee é um rio de águas negras, com concentrações de COD que variam de $25-75 \mathrm{mg} / \mathrm{L} \mathrm{e} \mathrm{pH}$ valores de $\mathrm{pH}$ inferior a 4,0. Para a coleta das amostras aquáticos padrão IHSS, o nível de água no pântano Okefenokee é regulamentado por uma série de barragens em parapeito ao longo da borda ocidental do pântano (IHSS, 2016).

\subsubsection{AH do Pahokee Standard (IHSS)}

A turfa Pahokee é um solo de turfa agrícola das Florida Everglades. A amostra IHSS foi obtido a partir da Universidade de Estação de Pesquisa Florida Belle Glade. A série Pahokee consiste em solos muito com pouca drenagem que são 36 a 51 polegadas de espessura ao longo do calcário. E forman-se em depósitos orgânicos de pântanos de água doce (IHSS, 2016).

\subsubsection{Propiedades do ácido húmico}

As sustâncias húmicas são macromoléculas com carga negativa, se clasificam em ácidos fúlvicos (solúvel em toda a faixa de $\mathrm{pH}$ ), ácidos húmicos (solúvel a partir de pH 2) e humina (insolúvel) (Theng, 2012).

A composição química dos ácidos húmicos varia com o tipo de solo, de biomassa que foi decomposto e dos produtos de decomposição. As análises dos elementos dos ácidos húmicos provenientes de diferentes solos deram a seguinte composição: $\mathrm{C}=54,5 \%, \mathrm{H}=4,8 \%, \mathrm{O}=36,7 \%$ e $\mathrm{N}=4,0 \%$, que gerou a fórmula empírica $\mathrm{C}_{16} \mathrm{H}_{17} \mathrm{O}_{8} \mathrm{~N}$ (Divakaran e Pillai, 2004).

Várias unidades estruturais são mantidas juntas por ligações covalentes e por pontes de hidrogênio. Nas soluções neutras, básicas ou em soluções de baixa força iônica, as moléculas assumem uma forma alongada por causa da repulsão eletrostática entre os grupos ionizados. Em soluções muito ácidas, ou elevada força iônica, as cadeias adotam uma forma enrolada, devido à neutralização de cargas em torno de agregados globulares e estruturas em forma de anel. 
A interação dos argilominerais com as sustancias húmicas aumenta com a força iônica do meio, permitindo as interações van der Waals. A interação do ácido húmico com a caulinita ocupa duas vezes mais a área superficial do mineral em baixa força iônica $(0.005 \mathrm{M})$ do que em alta força iônica $(0.1 \mathrm{M})$. Isso é ainda mais facilitado com a presença de cátions, sendo o $\mathrm{Ca}^{2+}$ mais efetivo do que $\circ \mathrm{Na}^{+}$ (Murphy et al., 1994). A ordem da adsorção de cátions no AH decresce na seguinte ordem: $\mathrm{Ca}^{+2}>\mathrm{H}^{+}>\mathrm{K}^{+}$, atuando como ponte entre os grupos do $\mathrm{AH}$ e as superfícies negativas das partículas; pode-se ter, ainda, a ligação por pontes hidrogênio, como apresentado na Figura 18. Em meio básico, a pouca estabilidade dos complexos argilominerais-ácidos húmicos é comprometida pelo hidróxido de sódio, devido à substituição dos cátions polivalentes pelos íons $\mathrm{Na}^{+}$, liberando os componentes húmicos em solução. Ao mesmo tempo, o grupamento hidroxila desloca os grupos aniônicos das sustâncias húmicas que estão ligados à borda do mineral, permitindo a dessorção do componente húmico (Theng, 2012).

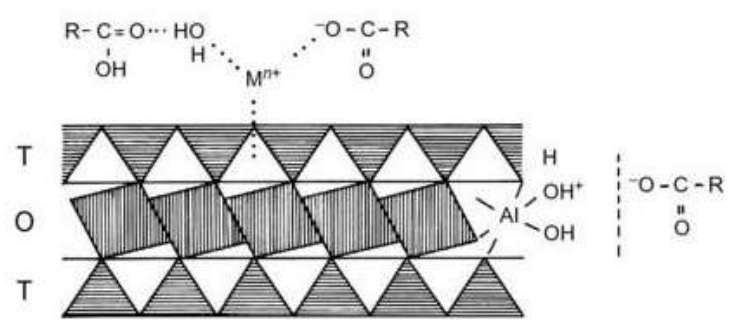

Figura 18 Interação entre substâncias húmicas (SH) e a camada de silicatos de argilominerais (Theng, 2012)

Outras forças de ligação podem também ocorrer entre ânions orgânicos e a superfície dos argilominerais, por exemplo: pontes de hidrogênio, entre os grupos polares da molécula orgânica e moléculas de água adsorvida ou por oxigênios da superficie do silicato. A força de ligação é pequena, mas eles são cumulativos; assim, a energia total de adsorção pode ser apreciável (Stevenson, 1994).

A estrutura molecular dos ácidos fúlvicos é menor do que a dos ácidos húmicos, no entanto os ácidos fúlvicos possuem maior quantidade de ácidos carboxílicos do que os ácidos húmicos, gerando uma reatividade maior de adsorção das partículas de argilominerais (Theng, 2012).

O método de titulação potenciométrica permite analisar o espectro de pK do ácido húmico, o qual apresenta três tipos de grupos funcionais, com valores de pK distribuídos em torno dos valores 3,62; 6,27 e 8,59 (Figura 19). Os dois primeiros tipos de grupos funcionais são, predominantemente, carboxílicos, enquanto que 0 
terceiro tipo, desprotonado, pode ser atribuído aos grupos fenólicos e a muito grupos carboxílicos fracos, com baixa contribuição dos grupos amina (Bratskaya, Schwarz e Chervonetsky, 2004).

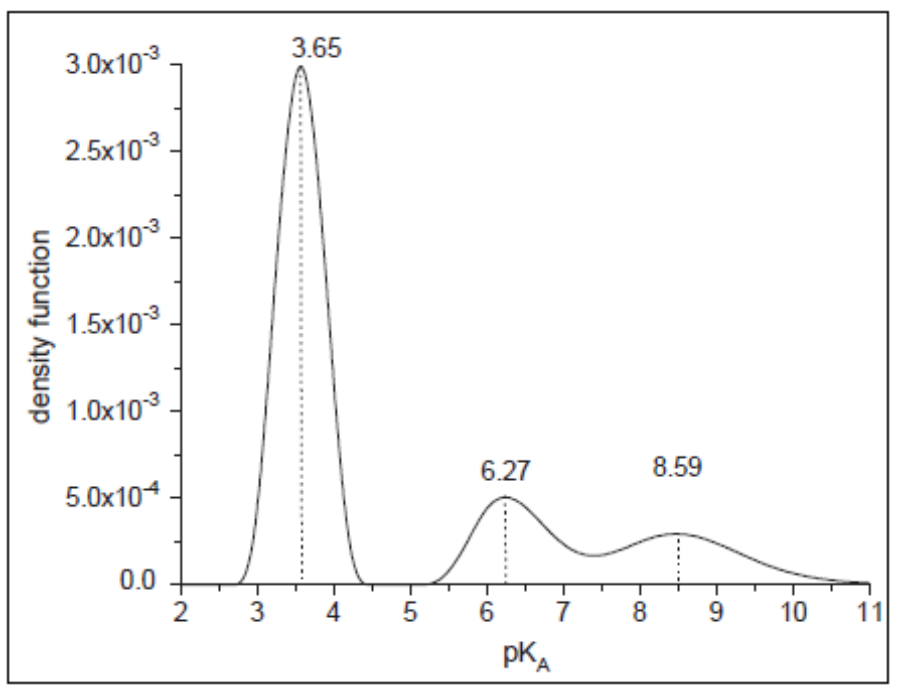

Figura 19 Espectro de constantes de dissociação pK do AH, (Bratskaya, Schwarz e Chervonetsky, 2004)

A adsorção do ácido húmico em argilominerais diminui com o incremento de $\mathrm{pH}$ de 3 a 6 , seguido de uma ligeira queda até $\mathrm{pH} 9$, devido às mudanças na ionização dos grupos carboxílicos, os quais estão fortemente ionizados a $\mathrm{pH}>6$. Este efeito desfavorável em meio básico pode ser parcialmente compensado na presença de cátions polivalentes (Theng, 2012). Os principais cátions polivalentes responsáveis pela ligação dos $\mathrm{AHs}$ com os argilominerais são ordenados, preferencialmente, conforme escala a seguir: $\mathrm{Fe}^{3+}=\mathrm{Al}^{3+}>\mathrm{H}^{+}>\mathrm{Ca}^{2+}>\mathrm{Sr}^{2+}>\mathrm{Mg}^{2+}$ $>\mathrm{K}^{+}>\mathrm{Na}^{+}>\mathrm{Li}^{+}$(Stevenson, 1994).

Os ácidos húmicos apresentam carácter zwitteriônico ${ }^{1}$. Alguns dos grupos $\mathrm{OH}$ e $-\mathrm{COOH}$ existem na forma ionizada de - $\mathrm{O}^{-}$e $\mathrm{COO}^{-}$, e alguns dos grupos $\mathrm{NH}_{2}$ estão na forma $-\mathrm{NH}^{+3}$ em pH neutro (Figura 20 (b)).

Quando o número de cargas negativas é maior do que o de cargas positivas em suspensões neutras, apresentando um caráter líquido negativo, e elas mesmas se estabilizam em suspensões aquosas.

Em baixos valores de $\mathrm{pH}$ do meio os grupos amino se protonam e se adsorvem na superfície negativa da caulinita (Figura 20 (a) e (b)), enquanto os ácidos fenólicos e carboxilicos são suprimidos. Devido à presença de cargas

\footnotetext{
${ }^{1}$ Zwitterion: molécula neutra com íons positivos e negativos.
} 
negativas a molécula tende novamente a estabilizar-se na suspensão, porém a adsorção das partículas minerais é maior com a diminuição do $\mathrm{pH}$, uma vez que o número de grupos - $\mathrm{NH}^{+}$aumenta. Em soluções básicas, os grupos $\mathrm{OH}$ - e COOestão ativos e a adsorção na caulinita é revertida (dessorção).

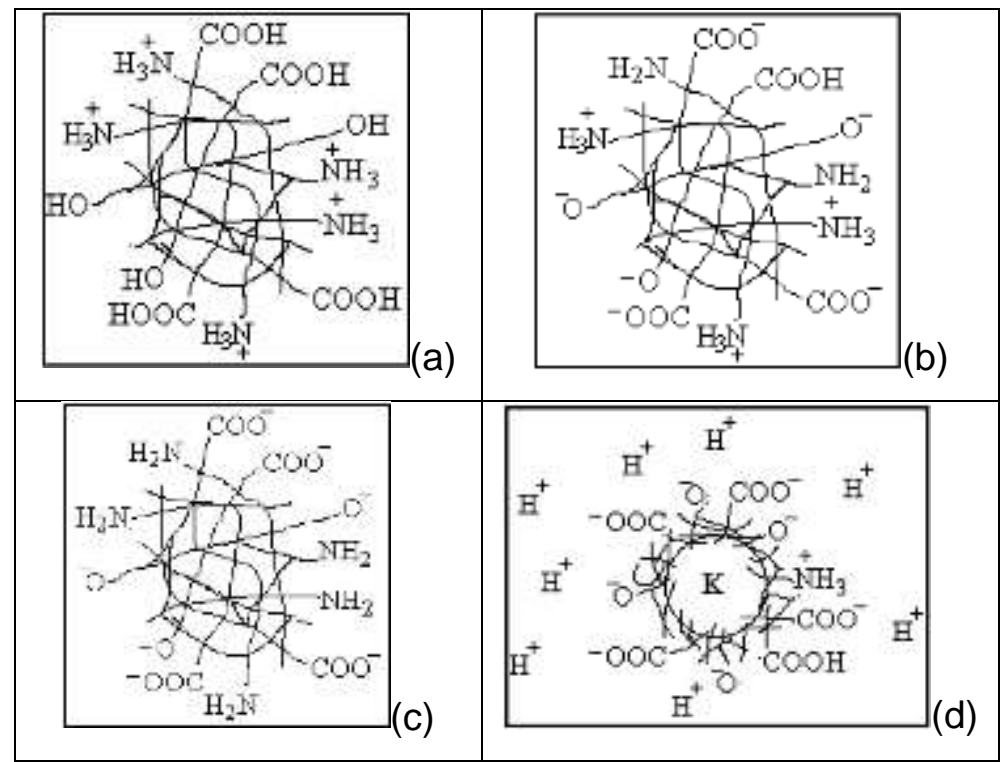

Figura 20 a), b) e c) Sustâncias húmicas em meio ácido, neutro e básico, respectivamente; d) adsorção em caulinita em pH neutro. Adaptado de Divakaran e Pillai (2004)

\subsubsection{Interação do ácido húmico com argilominerais}

Estudos usando montmorillonita mostram que a adsorção aumenta com a diminuição do pH (Divakaran e Pillai, 2004). Os cátions metálicos podem ser adsorvidos por troca com os prótons associados aos grupos funcionais do $\mathrm{AH}$, tais como, carboxílico, fenólico, especialente em meio ácido (Theng, 2012)(Divakaran e Pillai, 2004).

O estudo realizado por Vermeer, Riemsdijk, Van e Koopal (1998) indicam que em baixos valores de $\mathrm{pH}$ e alta força iônica, uma parte das moléculas de $\mathrm{AH}$ não está em contato direto com a superfície da hematita, enquanto que em meio alcalino e de baixa força iônica, as moléculas são adsorvidas na sua conformação estendida.

Em meio ácido as reações dos argilominerais ocorrem por hidrólise (ataque do próton) da ligação metal-oxigênio (M-O) na superfície da partícula e posterior complexação do íon metálico com o ácido húmico (Amram e Ganor, 2005). Alguns minerais micáceos, como a vermiculita, são mais reativos ao ácido húmico, do que 
a biotita, porque as camadas de silicato na vermiculita estão separadas por íons hidratados de $\mathrm{Mg}^{+2}$ (Theng, 2012).

Na Figura 21 é apresentado um gráfico de variação de potencial zeta com a concentração do AH em presença da magnetita, hematita e quarzo. Quando a concentração inicial do HA foi incrementada, os potenciais zeta de magnetita e hematita aumentou o potencial zeta para mais eletronegativo. Entretanto, a magnetita foi muito mais carregada negativamente do que a hematita, que deu origem a uma maior repulsão eletrostática entre o HA e a magnetita. Portanto, menos moléculas negativas de AH carregadas entraram na dupla camada elétrica da magnetita. Para o quartzo não houve variação do potencial zeta, o que significa que não houve a adsorção do $\mathrm{AH}$ (Zhou et al., 2014).

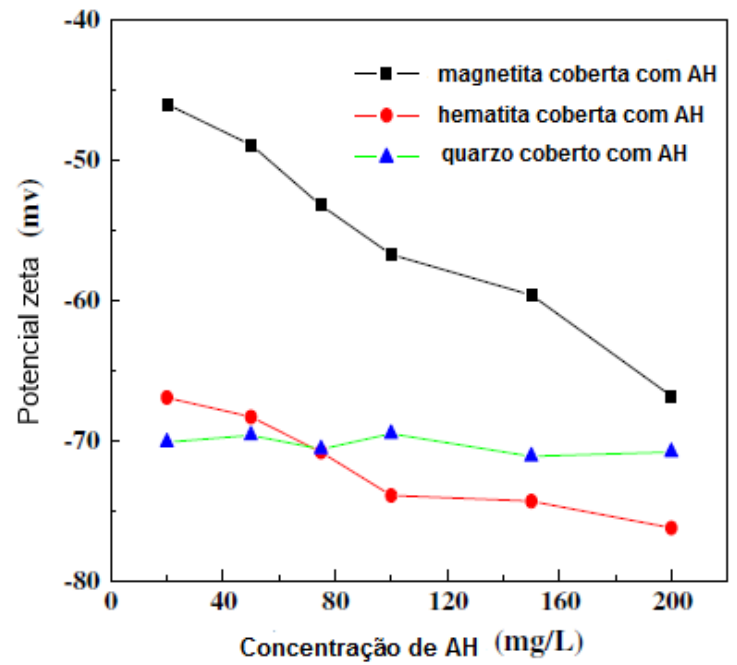

Figura 21 Adsorção do AH na magnetita, hematita e quarzo. Adotado de (Zhou et al., 2014)

\subsubsection{Interação ácido húmico com quitosana}

A densidade de carga na formação do complexo quitosana/ácido húmico $(\mathrm{CH} / \mathrm{HA})$ em várias proporções de misturas polímero-polímero (Figura 22), foi estudada por Bratskaya, Schwarz e Chervonetsky (2004). A máxima eficiência de floculação (> 95\%) com quitosana $(\mathrm{CH})$, expressa como remoção de cor, ocorreu no ponto isoelétrico (pi) a $\mathrm{pH}=7$, para uma relação mássica $\mathrm{CH} / \mathrm{HA}$ igual a 1,0 .

O aumento do consumo do polímero catiônico em meio neutro pode resultar da rápida desprotonação da quitosana, que não permite que todos os seus sítios catiônicos interajam com os sítios aniônicos do HA (Bratskaya, Schwarz e Chervonetsky, 2004). 


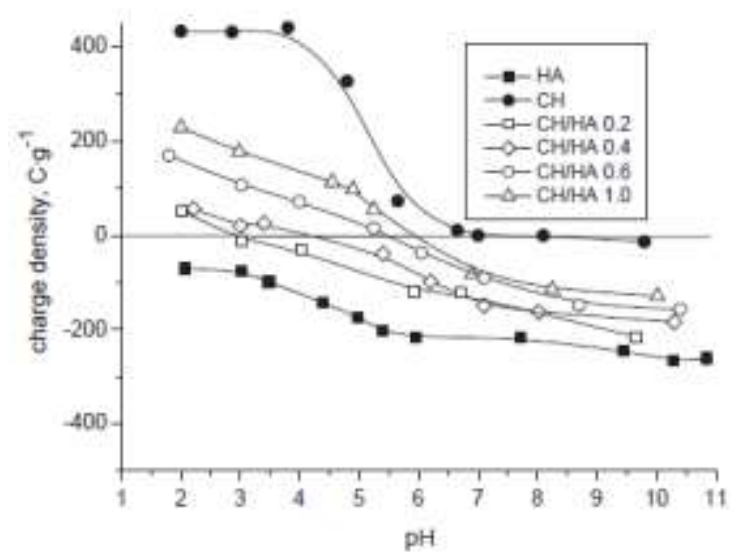

Figura 22 Densidade de carga dos complexos de polieletrolitos $\mathrm{CH} / \mathrm{HA}$, (Bratskaya, Schwarz e Chervonetsky, 2004)

O potencial zeta mostrado na Figura 22 indicou que os grânulos com revestimento de quitosana apresentaram potenciais zeta positivos em $\mathrm{pH}<6,6$ e potenciais zeta negativos em $\mathrm{pH}>6,6$. As adsorções dos ácidos húmicos nas partículas foram pré-revestidas com quitosana mostrou-se fortemente dependente do $\mathrm{pH}$. Quantidades significativas de ácidos húmicos foram absorvidos sob condições ácidas e neutras de $\mathrm{pH}$, mas a capacidade de adsorção foi notavelmente reduzida com o aumento do $\mathrm{pH}$ da solução.

Em valores de $\mathrm{pH}$ menores que 7 , os potenciais zeta das partículas recobertas com quitosana aumentou quase linearmente com a diminuição do $\mathrm{pH}$ da solução de 7 para 3 , isto pode ser atribuído à protonação dos grupos amino no revestimento da quitosana (isto é, $-\mathrm{NH}^{2+}$ para $\mathrm{NH}^{+3}$ ). Para a faixa de $\mathrm{pH}$ de 7 a 12 , os potenciais zeta negativos das partículas com quitosana adsorvida, não diminuim o potencial da solução significativamente com o aumento do $\mathrm{pH}$, o que indica que o grupo amino da quitosana na superfície das partículas não sofreu desportonação sob estas condições de $\mathrm{pH}$ (ou seja, da- $\mathrm{NH}_{2}$ para $-\mathrm{NH}^{-}$). Os potenciais zeta negativos de ácido húmico podem ser devido à dissociação do $\mathrm{H}^{+}$ dos grupo carboxílicos e fenólicos nas macromoléculas do ácido húmico (Zhang e Bai, 2003).

\subsubsection{Interação ácido húmico com quitosana nos argilominerais}

A adsorção de ácido húmico com um polímero catiônico na superfície da hematita foi estudada por (Kim e Walker, 2001). Em valores baixos de pH e na ausência de polímero, as partículas apresentaram carga positiva, promovendo a 
eficiente adsorção do ácido húmico nas partículas minerais. Na presença do polímero e do ácido húmico, a adsorção diminuiu ligeiramente, para a mesma faixa de $\mathrm{pH}$. Em valores de $\mathrm{pH}$ elevados, as partículas apresentaram carga negativa e, portanto, a adsorção somente do ácido húmico foi inexpressiva; já a adsorção conjunta dos dois polímeros na superfície da hematita, devido a elevada densidade de carga, foi favorecida pelo aumento das as interações eletrostáticas.

Segundo o estudo de (Divakaran e Pillai, 2004), a caulinita pode ser facilmente removida de suspensões aquosas por floculação e sedimentação utilizando quitosana, desde que seja utilizada, em conjunto, pequenas concentrações (traços) de substâncias húmicas.

\subsubsection{Mecanismos de reação ou de ligações na adsorção polímero/argila}

Vários mecanismos estão envolvidos na adsorção de polimeros naturais por minerais de argila, duas ou mais mecanismos podem operar simultaneamente, dependendo das propriedades dos polimeros naturais, a natureza do catião permutável na argila, acidez superficial e teor de humidade no sistema, sendo os principais: (Stevenson, 1994; Theng, 2012).

\subsubsection{Ligação Física ( forças de van der Waals)}

Apresentan-se entre todas as moléculas, mas são bastante fracos. Resultam das variações na densidade de carga eléctrica de átomos individuais. Uma variação eletricamente positiva em um átomo tende a produzir uma variação eletricamente negativa em um átomo vizinho, e gerando uma red de forças atrativas resultante. Para polímeros naturais ou compostos orgánicos não polares, as interações de van der Waals podem dominar o processo de adsorção, particularmente aqueles que são altos em massa molar.

\subsubsection{Ligação eletrostática}

Ocorre através do processo de troca de cátions ou protonação. O primeiro ocorre quando catiões orgânicos carregados positivamente substituem catiões inorgânicos no complexo de troca, como interações dipolo (por exemplo a quitosana apresenta grupos amino), como segue na reação: 


$$
\text { argila- }-\mathrm{M}^{+}+\mathrm{R}-\mathrm{NH}_{3}^{+} \rightleftharpoons \text { argila- }{ }_{-}^{+} \mathrm{NH}_{3} \mathrm{R}+\mathrm{M}^{+}
$$

Figura 23 Troca de cátions orgânicos com cátions inorgânicos, (Stevenson, 1994)

A propriedade catiónica de uma molécula fracamente básico é fortemente dependente do $\mathrm{pH}$. A adsorção é também influenciada pelas propriedades do catião orgânico (por exemplo, comprimento da cadeia) e o tipo de catião no complexo de troca (Stevenson, 1994).

Tal como será mostrado posteriormente, compostos orgânicos que são fracamente básico podem ser adsorvido na superfície das partículas através da protonação, um processo no qual uma molécula orgânica assume uma carga positiva, aceitando um iõe $\mathrm{H}^{+}$.

\subsubsection{Ponte hidrógeno}

É uma ligação entre dois átomos electronegativos através da ligação com um único iõe $\mathrm{H}^{+}$. O iõe $\mathrm{H}^{+}$com uma carga de +1 , tem uma forte tendência a compartilhar electrões com átomos que contêm um par de electrões não compartilhados, tal como o oxigénio. O vínculo é mais fraco do que as ligações iônicas ou ligações covalentes mas mais forte do que as forças de van dar Waals de atração.(Stevenson, 1994; Theng, 2012) As ligações de com o hidrogênio que podem ocorrer em superfícies de argila são apresentadas a seguir (Stevenson, 1994):

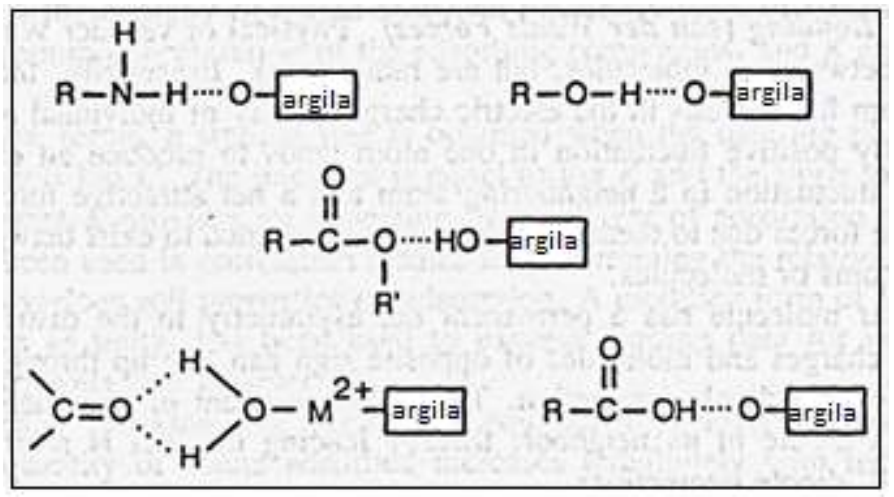

Figura 24 Ligações de H com superfícies de argila (Stevenson, 1994) 


\subsubsection{Interações das argilominerais com as substâncias húmicas}

A adsorção dos ácidos húmicos e fúlvicos por minerais de argila, tais como montmorilonite ocorre apenas quando estão presentes os catiões polivalentes no complexo de troca. Ao contrário do $\mathrm{Na}^{+}$e $\mathrm{K}^{+}$os catiões polivalentes são capazes de manter a neutralidade na carga sobre a argila e do grupo funcional ácidico da matéria orgânica (por exemplo COO-).

O principais catiões polivalentes responsáveis pela ligação dos ácidos húmicos e fúlvicos para argilas são $\mathrm{Ca}^{2+} \mathrm{Fe}^{3+}$ e $\mathrm{Al}^{3+}$. $\mathrm{O}$ iõe divalente $\mathrm{Ca}^{2+}$ não forma complexos de coordenação fortes com as moléculas orgânicas e seria efetivo apenas na medida em que uma ponte de ligação pode ser formado. Pelo contrário, com o $\mathrm{Fe}^{3+}$ e $\mathrm{Al}^{3+}$ formam complexos de coordenação fortes com substâncias húmicas, neste caso o deslocamento do metal ligado é difícil.

Como se pode observar na Figura 25 (a), o catião polivalente atua como uma ponte entre dois sítios de carga. Neste caso, a água de hidratação do catião não é deslocado, mas forma uma ligação de $\mathrm{H}^{-}$com o anião orgânico. $\mathrm{Na}$ Figura 25 (b),o anião orgânico fica coordenado ao catião com o deslocamento de uma molécula de água da camada de hidratação (em meio ácido). Para uma molécula do polimero de cadeia longa vários pontos de ligação à partícula de argila são possiveis (Stevenson, 1994; Theng, 2012).

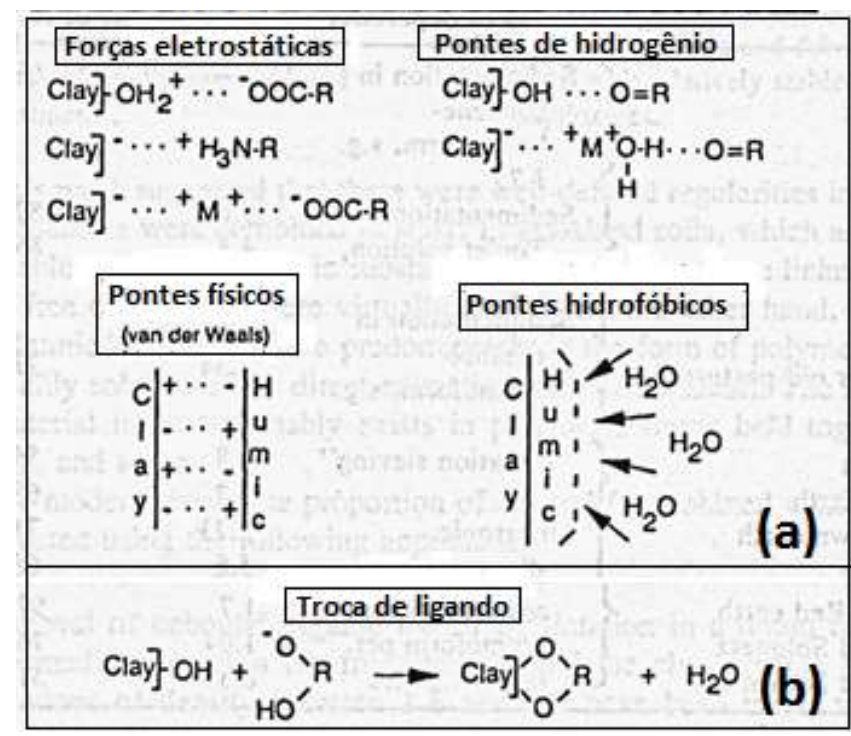

Figura 25 Mecanismos de adsorção das argilominerais com as substâncias húmicas, (Stevenson, 1994). 
4

Materiais e métodos

\subsection{Materiais}

> A quitosana e o ácido húmico foram adquiridos da Sigma Aldrich Chemical Co.

$>$ O rejeito de níquel é proveniente da usina de beneficiamento de minerales do estado Minas Gerais.

> A lama vermelha é proveniente da usina de beneficiamento de minerales do estado do Pará.

\subsection{Procedimento experimental}

A metodologia desenvolvida teve como foco monitorar os efeitos das diversas variáveis envolvidas nas propriedades da floculação do rejeito de $\mathrm{Ni}$ e da lama vermelha respectivamente. As variáveis de estudo foram:

$>$ Concentração de sólidos (\%)

$>$ Dosagem de ácido húmico ( $\mathrm{g} / \mathrm{t}$ de minério tratado)

$>$ Dosagem de quitosana ( $\mathrm{g} / \mathrm{t}$ de minério tratado)

$>$ Velocidade de agitação (rpm)

$>$ Tempo de agitação (rpm)

> Turbidez do sobrenadante (variável de resposta) (NTU).

\subsection{Preparação da quitosana}

A solução estoque de quitosana foi preparada pela dissolução de $1,0 \mathrm{~g}$ de quitosana em $1 \mathrm{~L}$ de uma solução de $0,025 \mathrm{M} \mathrm{HCl}$, agitado durante $24 \mathrm{~h}$ (Bratskaya, Schwarz e Chervonetsky, 2004). 


\subsection{Preparação do ácido húmico}

A solução estoque do ácido húmico foi preparada por dissolução de $1,0 \mathrm{~g}$ de ácido húmico em $1 \mathrm{~L}$ de uma solução de $0.1 \mathrm{M}$ de $\mathrm{KOH}$, agitado por 48 horas e filtrado por um filtro de papel (Whatman no 1) (Zouboulis, Jun e Katsoyiannis, 2003).

Após a otimizacao das condições experimentais dos sitemas níquel e lama vermelha, foram realizados ensaios de floculação/sedimentação, com o intuito de validar os modelos matemáticos obtidos. Nesses ensaios foram utilizadas a quitosana e amostras de ácidos húmicos obtidos a partir de diferentes fontes (Figura 26), a fim de comparar a eficiência entre eles. Foram preparadas soluções estoque de 1000 ppm e diluídas para soluções de 25 ppm, para a floculação.

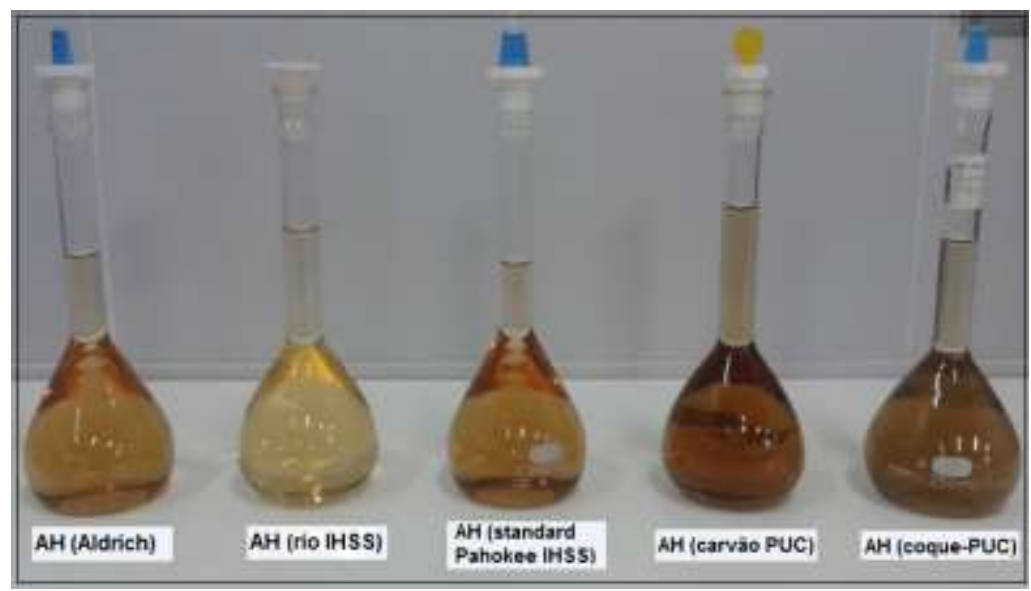

Figura 26 Soluções dos diferentes ácidos húmicos (25ppm)

\subsection{Preparação das amostras}

Para obter um bom desempenho na caracterização mineralógica, bem como nos ensaios realizados no projeto é preciso realizar uma amostragem representativa e uma eficiente operação de homogenização das amostras, pois, representam sistemas particulados que são geralmente misturas de partículas de tamanho, forma e de composição variados.

As sub-amostras utilizadas nesse trabalho (20 quilos) foram coletadas de amostras de rejeito de níquel e lama vermelha disponíveis no CETEM, por meio de amostragem em pilha de homogeneização e quarteamento. 


\subsubsection{Preparação da amostra de rejeito de Ni}

A amostra de rejeito foi recebida ainda com umidade e encontrava-se na forma de torrões de diferentes tamanhos e com cerca de 1\% de umidade (Figura 27a). Para a desagregação das partículas o material foi passado em um britador de mandíbulas secundário, (Figura 27b), e para a desagregação das partículas menores, foi preciso peneirá-las em uma peneira série Tyler com abertura de 104 $\mu \mathrm{m}$, (Figura 27c). Depois, realizou-se a homogenização da amostra que tem por objetivo obter uma distribuição uniforme dos constituintes, para permitir um quarteamento equitativo em frações de menor massa, assim o método utilizado é a pilha de homogeneização (Figura 27d). Finalmente, é montada a pilha longitudinal, para depois realizar o quarteamento da amostra e são retiradas alíquotas para a realização de análises química e mineralógica, bem como dos ensaios de laboratório e testes de floculação. (Figura 27e).

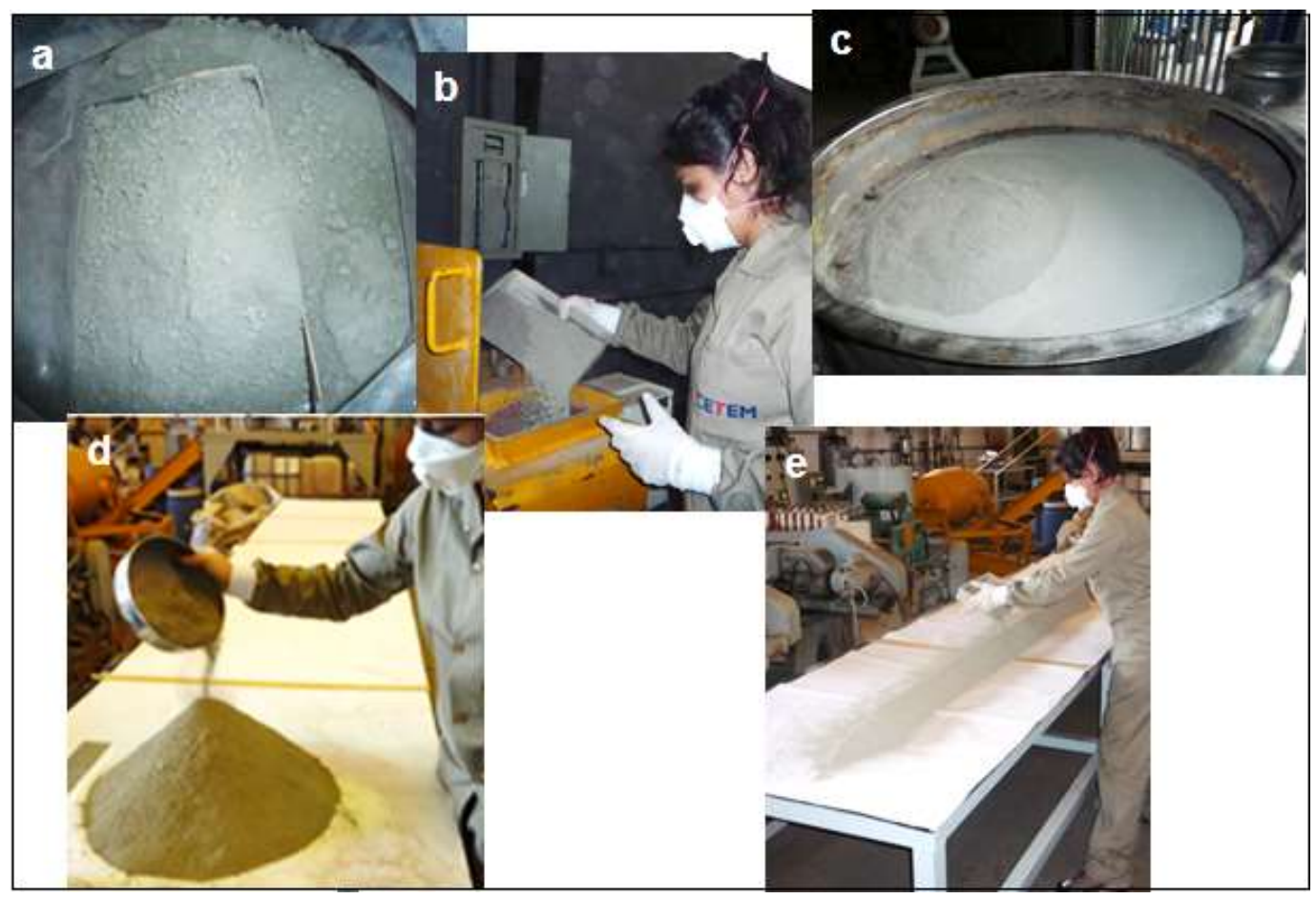

Figura 27 Preparação da amostra de rejeito de $\mathrm{Ni}$

\subsubsection{Preparação da amostra de lama vermelha}

A amostra da lama vermelha, encontrava-se também na forma de torrões e com uma umidade residual de 15\%, (Figura 28a). Para a desagregação de partículas o material foi cominuído em um britador de mandíbulas secundário, 
(Figura 28b). A homogenização foi realizado do mesmo jeito do que o rejeito de $\mathrm{Ni}$, com a formação da pilha (Figura 28c). E da pilha longitudinal, realizou-se o quarteamento da amostra e são retiradas alíquotas para a realização de análises química e mineralógica, bem como dos ensaios de laboratório, e testes de floculação (Figura 28d).

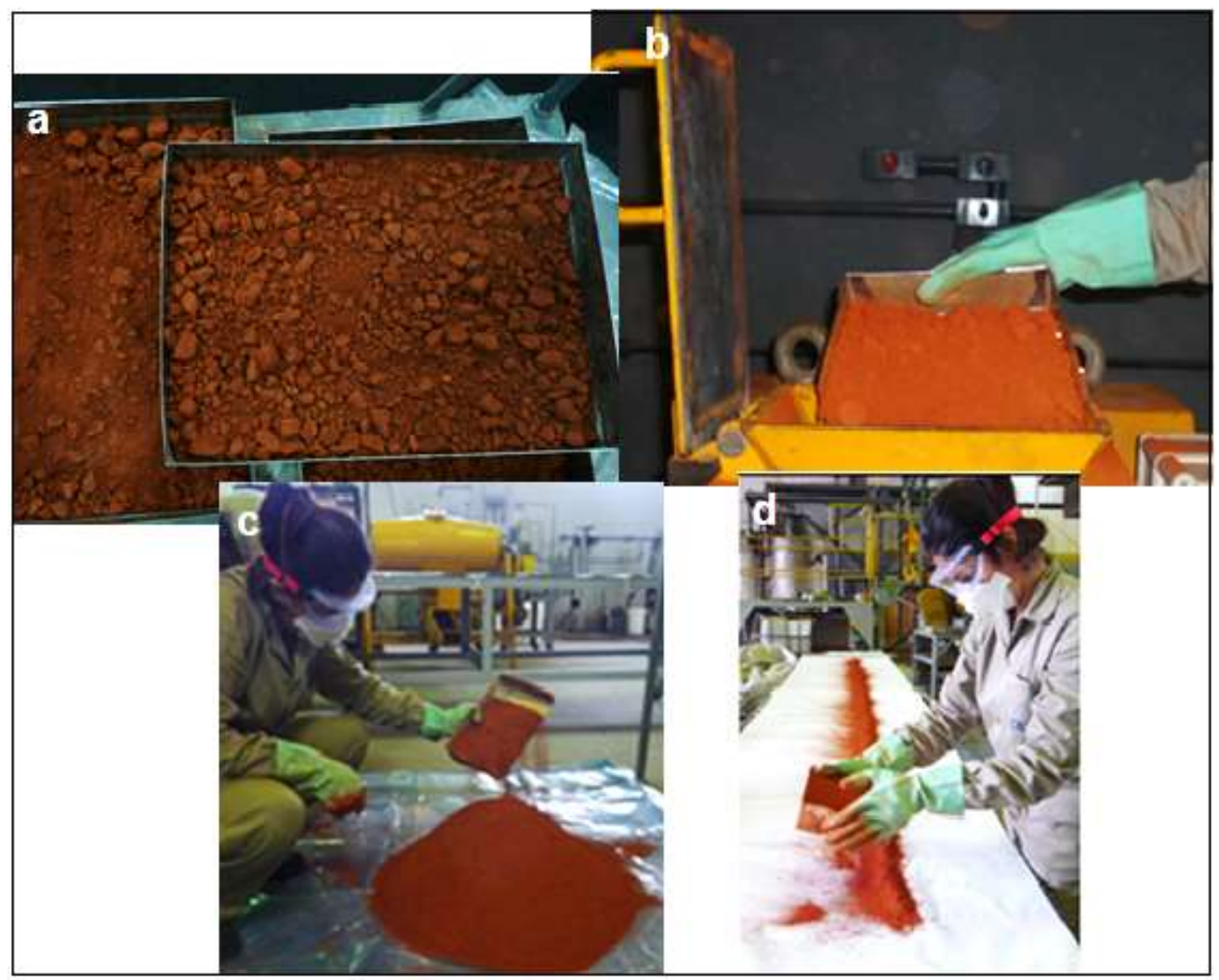

Figura 28 Preparação da amostra da lama vermelha

A Figura 29 descreve a sequencia desenvolvida para a realização dos testes de floculação para o rejeito de $\mathrm{Ni}$ e para a lama vermelha. 


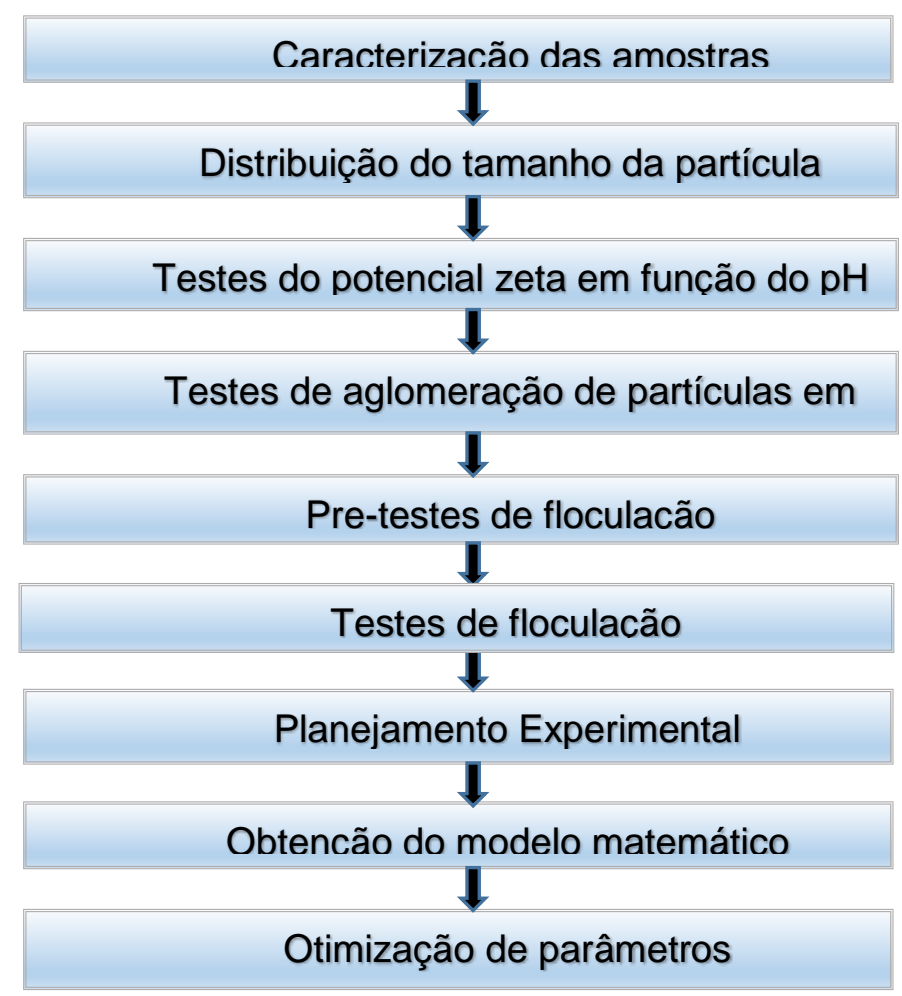

Figura 29 Esquema do plano de trabalho experimental

\subsection{Caracterização dos rejeitos}

\subsubsection{Análise química}

As análises químicas foram realizadas via úmida, mediante procedimento de abertura ácida da amostra e leitura em um espectrômetro de absorção atômica 50B, da marca Varian. Esse procedimento analítico foi utilizado, igualmente, para as amostras de rejeito de $\mathrm{Ni}$ e lama vermelha.

\subsubsection{Análise granulométrica}

A eficiência de separação sólido-líquido de uma polpa mineral é função da distribuição de tamanho das partículas presentes. Partículas em suspensão, que possuem diâmetro médio superior a $2 \mu \mathrm{m}$, podem ser removidas por sedimentação simples. Entretanto, partículas coloidais, com diâmetros menores do que $1 \mu \mathrm{m}$ e visíveis apenas através de microscopia eletrônica, exigem a coagulação e floculação para a separação eficiente. Porém, é preciso analisar e quantificar a presença dessas partículas na amostra de estudo. $O$ instrumento de medição da distribuição de tamanhos foi um difratômetro a laser, Mastersizer 
2000, da Malvern Instruments, que utiliza a técnica de medida por espalhamento de luz.

Para a realização dessa análise, a amostra foi seca a $60^{\circ} \mathrm{C}$ por 3 horas em estufa, e após resfriamento, foi desagregada em peneira de abertura $297 \mu \mathrm{m}$ (48 mesh). (Figura 30). Esse procedimento analítico foi utilizado, igualmente, para as amostras de rejeito de $\mathrm{Ni}$ e lama vermelha.

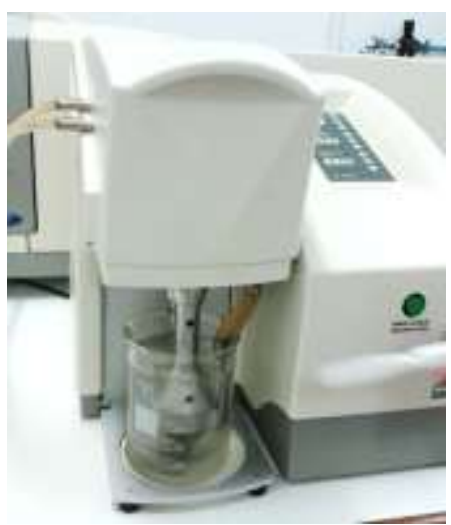

(a)

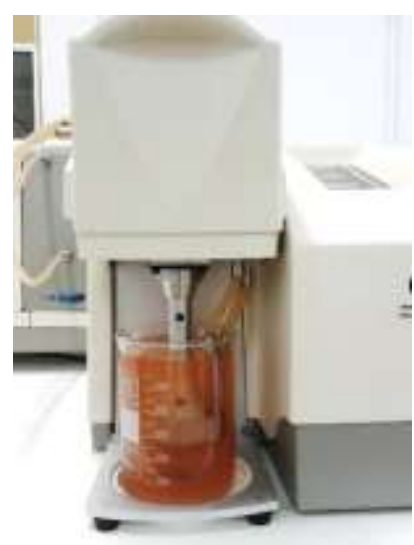

(b)

Figura 30 Análise granulométrica: (a) rejeito de $\mathrm{Ni}$, (b) lama vermelha

\subsubsection{Determinação da densidade aparente}

Para a determinação da densidade da polpa a técnica utilizada foi a picnometria (Sampaio e Silva, 2007) e o cálculo foi realizado com , com base na Equação (17). Esse procedimento analítico foi utilizado, igualmente, para as amostras de rejeito de $\mathrm{Ni}$ e lama vermelha.

$$
d s=\frac{\left(m_{2}\right)-\left(m_{1}\right)}{\left(m_{4}+m_{2}\right)-\left(m_{1}+m_{3}\right)}
$$

Onde:

ds = densidade dos sólidos;

$\mathrm{m}_{1}=$ massa do picnômetro;

$\mathrm{m}_{2}=$ massa do picnômetro + amostra;

$\mathrm{m}_{3}=$ massa do picnômetro + amostra + água;

$\mathrm{m}_{4}=$ massa do picnômetro + água; 


\subsubsection{Determinação da Umidade}

A umidade das amostras foi determinada em balança analisadora de umidade MB23, fabricada pela Toledo do Brasil. Esse procedimento analítico foi utilizado, igualmente, para as amostras de rejeito de Ni e lama vermelha.

\subsubsection{Difração de Raios $X$}

Os difratogramas de Raios-X (DRX) das amostras, obtidos pelo método do pó, foram coletados em um equipamento Bruker-D4 Endeavor, nas seguintes condições de operação: radiação Co Ka $(35 \mathrm{kV} / 40 \mathrm{~mA})$; velocidade do goniômetro de $0,02^{\circ} \mathrm{2q}$ por passo com tempo de contagem de 1 segundo por passo e coletados de 5 a $80^{\circ}$ 2q. As interpretações qualitativas de espectro foram efetuadas por comparação com padrões contidos no banco de dados do software Bruker AXS Diffrac.Plus.

Esse procedimento analítico foi utilizado, igualmente, para as amostras de rejeito de Ni e lama vermelha.

\subsubsection{Microscopia Eletrônica de Varredura (MEV)}

As analises foram efetuadas num microscópio eletrônico de varredura (MEV) FEI Quanta 400 com um sistema de microanálise química por dispersão de energia (EDS) Bruker Quantax acoplado. Esse procedimento analítico foi utilizado, igualmente, para as amostras de rejeito de Ni e lama vermelha.

\subsubsection{Infravermelho}

A maioria dos compostos tem ligações covalentes, sejam orgânicos ou inorgânicos, cada tipo tem sua própia frequência natural de vibração. A absorção de radiação no infravermelho é, como outros processos de absorção, um processo quantizado. (Paiva et al., 2010). Uma molécula absorve apenas frequências (energias) selecionadas de radiação do infravermelho. A região do infravermelho vibracional do espectro eletromagnético em termos de unidade é chamada número de onda $\left(\mathrm{cm}^{-1}\right)$.

O equipamento utilizado foi um FTIR Thermo Nicolet 6700 , com o software OMINIC, para determinação dos grupos funcionais da quitosana e do ácido húmico. As amostras foram analisadas sem diluição. 


\subsubsection{Determinação do pH}

A floculação das polpas é um processo dependente do $\mathrm{pH}$; existe uma condição denominada "pH ótimo" de floculação que corresponde à situação em que as partículas coloidais apresentam uma compreensão da dupla camada elétrica.

As medidas de $\mathrm{pH}$ foram realizadas em diferentes etapas do estudo, como medidas de carga superficial e testes de floculação. As determinações de pH foram realizadas com o auxílio de um medidor de pH, DM-22 (Digimed). Antes das determinações, o pHmetro foi calibrado com soluções tampão de pH de 4, 7 e 10, respectivamente.

Esse procedimento analítico foi utilizado, igualmente, para as amostras de rejeito de $\mathrm{Ni}$ e lama vermelha.

\subsubsection{Medida do potencial eletrocinético}

Esta análise indica o potencial de aproximação dos colóides (entre a camada difusa e da camada de Stern), medindo o potencial eletrostático entre a separação das camadas vizinhas da partícula e o potencial zeta; essa medida indica o ponto de neutralização de cargas das partículas em um determinado pH (Zeta-Meter, n.d.).

As medidas foram realizadas em equipamento analisador de potencial zeta, de fabricação da Brookhaven Instruments Corp. A amostra foi moída até uma granulometria menor que $20 \mu \mathrm{m}$, por determinação da metodologia de análise do equipamento). Foram adicionados $0,5 \mathrm{~g}$ de amostra a $0,5 \mathrm{~L}$ de água Mili- $\mathrm{Q}$, para duas concentrações de eletrólito indiferente $\left(0,001 \mathrm{M}\right.$ e $0,01 \mathrm{M}$ de $\left.\mathrm{KNO}_{3}\right)$. A polpa foi dividida em várias sub-amostras, para ajustes de $\mathrm{pH}$, na faixa de 3 a 12, com soluções de $\mathrm{HCl}$ 0,1 M e KOH 0,1 M, mantendo a mistura sob agitação contínua e temperatura controlada em $25^{\circ} \mathrm{C}$; após 5 min de repouso a amostra foi, então, analisada.

Esse procedimento analítico foi utilizado, igualmente, para as amostras de rejeito de $\mathrm{Ni}$ e lama vermelha.

\subsubsection{Testes de floculação para o rejeito de $\mathbf{N i}$}

Uma vez que as partículas estão desestabilizadas, a etapa seguinte é a formação dos flocos. Para isso é necessário que se introduza energia ao meio de forma adequada, pois a deficiência de energia permite pouco contato entre as 
partículas, dificultando a formação de flocos, enquanto que a energia excessiva provoca a ruptura dos flocos formados. O fornecimento adequado de energia provoca a formação de flocos grandes e densos, com ramificações que promovem entrelaçamentos entre os flocos, formando estruturas maiores e mais pesadas, (Bohuslav, 1993).

Estes ensaios foram realizados em equipamento Jar test, da marca Nova Ética, (Figura 31). Para a quantidade de amostra utilizada em cada teste, seguiram um planejamento experimental, baseada nas seguintes variáveis que são: concentração de sólidos, dosagem de reagentes floculantes, velocidade e tempo de agitação, cujo detalhamento será apresentado nas seções seguintes.

A polpa teve uma agitação rápida inicial de homogenização de 3 min. Para o rejeito de $\mathrm{Ni}$ não foi preciso o ajuste de $\mathrm{pH}$, pelas características que apresentou da análise de carga superficial. A mistura dos floculantes (quitosana e ácido húmico), dependeram das condições do planejamento experimental, depois se deu 1 min de agitação lenta para fomentar o crescimento de flocos, finalmente depois de 1 hora de sedimentação, realizou-se a leitura da turbidez da solução do sobrenadante.

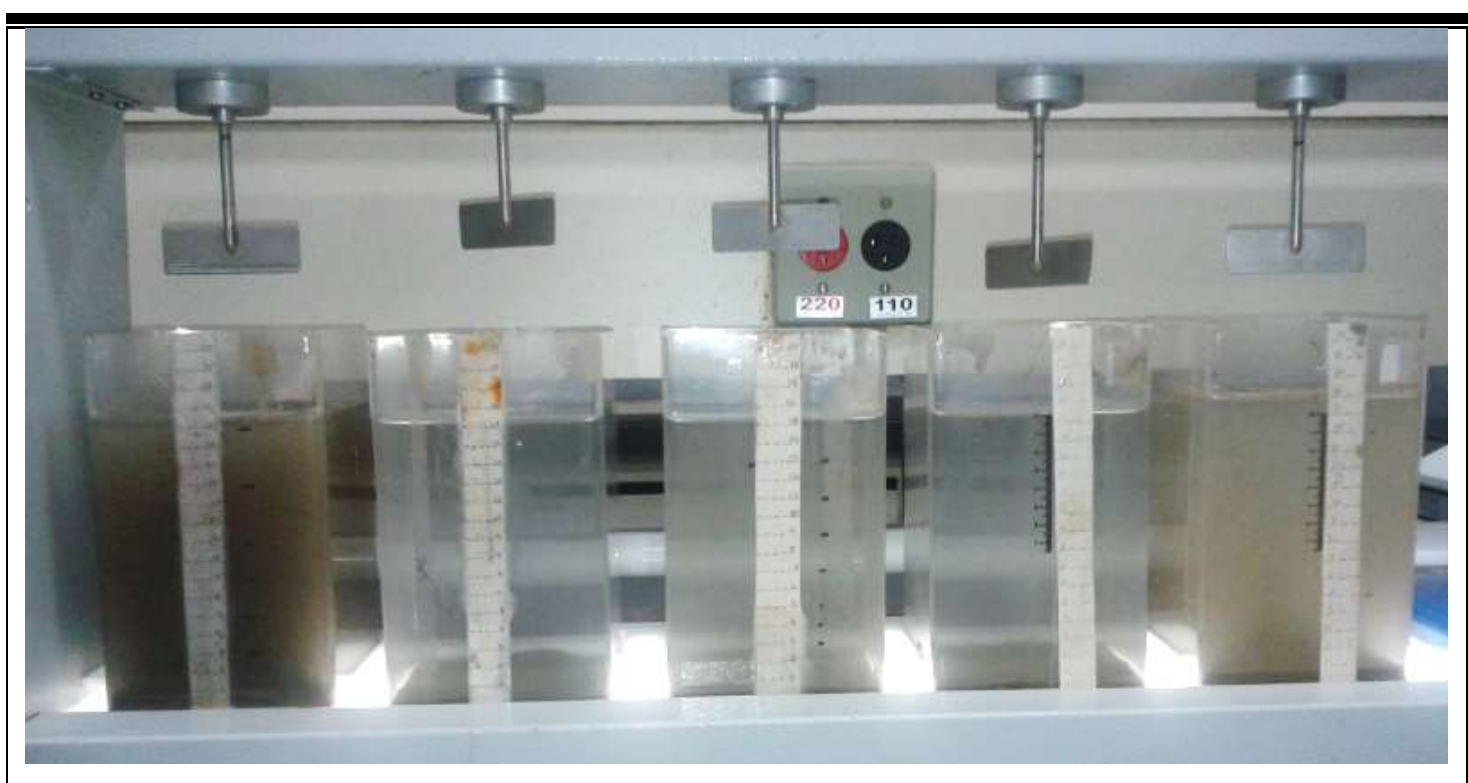

Figura 31 Testes de floculação no Jar test do rejeito de $\mathrm{Ni}$

\subsubsection{Testes de floculação para a lama vermelha}

Os ensaios da lama vermelha também foram realizados no equipamento Jar test, da marca Nova Ética (Figura 32). Para a quantidade de amostra utilizada em 
cada teste, seguiram um planejamento experimental, baseada também nas mesmas variáveis do que o rejeito de $\mathrm{Ni}$ que são: concentração de sólidos, dosagem de reagentes floculantes, velocidade e tempo de agitação, cujo detalhamento será apresentado nas seções seguintes.

A polpa teve uma agitação rápida inicial de homogenização de 3 min. Logo no o ajuste de $\mathrm{pH}$, a lama vermelha é um rejeito com a caracteristica de apresentar um $\mathrm{pH}$ muito básico, $(10 \leq \mathrm{pH} \leq 12)$, porém mediante a análise de carga superficial, se avaliou um $\mathrm{pH}$ de floculação onde as partículas apresentaram menor desestabilização de partículas nessa faixa de $\mathrm{pH}$ (meio básico). A mistura dos floculantes (quitosana e ácido húmico), dependeram das condições do planejamento experimental, depois se deu 1 min de agitação lenta para fomentar o crescimento de flocos, finalmente depois de 1 hora de sedimentação, realizouse a leitura da turbidez da solução do sobrenadante.

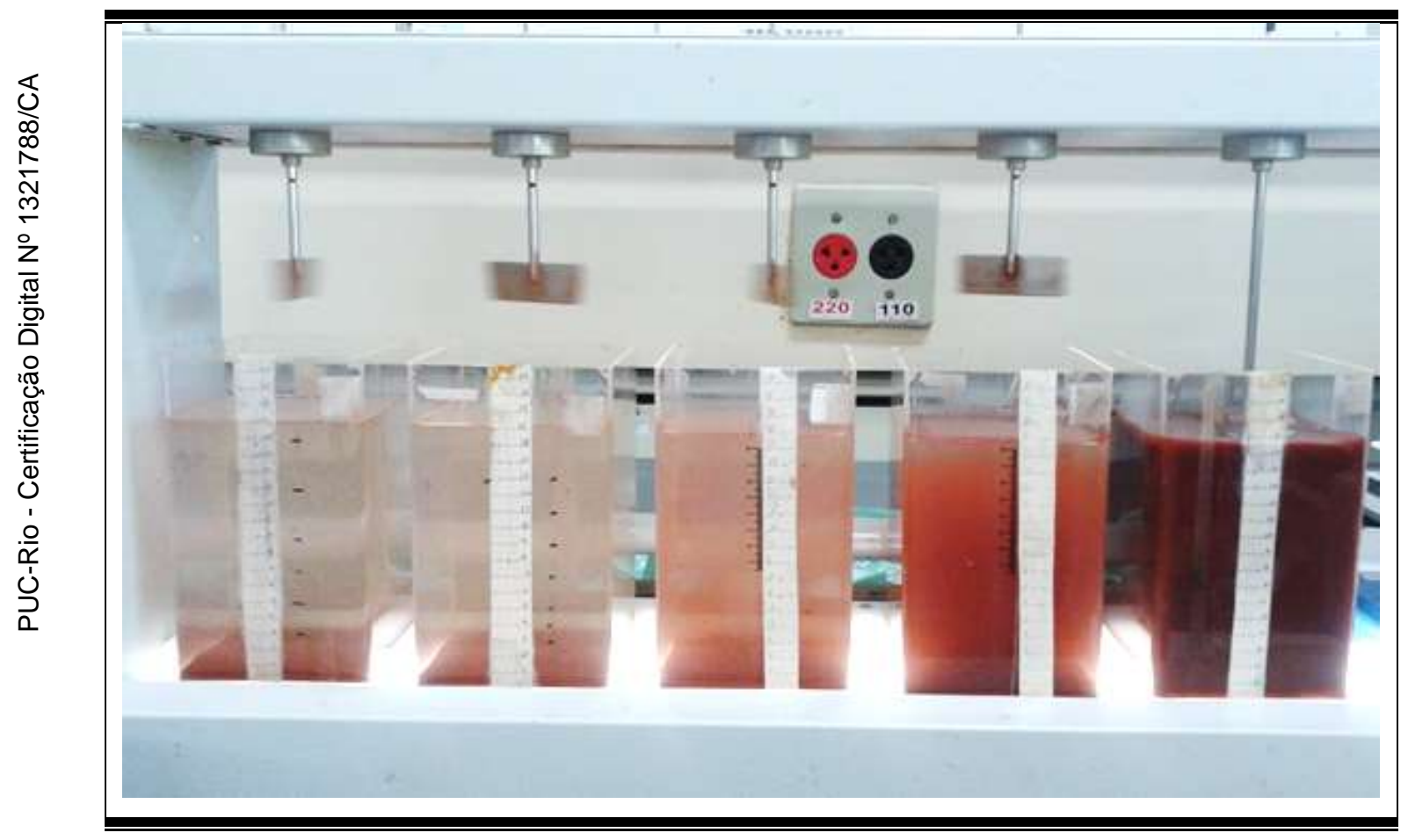

Figura 32 Testes de floculação no Jar test da lama vermelha

\subsubsection{Medição de turbidez}

A sedimentação é uma operação baseada no transporte de partículas sólidas através de um meio líquido, sujeitas às forças da gravidade, empuxo e resistência ao movimento (França e Casqueira, 2007). 
Em suspensões floculadas (Figura 33) o processo de sedimentação visível corresponde ao decréscimo da zona 2 e aumento da zona 1. É muito difícil identificar a zona 3, a zona 4 é a zona final onde são observadas duas regiões: uma de líquido clarificado e uma de sedimentos. Em suspensões diluídas a zona 1 é dificilmente identificada, já que o líquido acima da região de compressão se mantém turvo, indicando a presença de material particulado em suspensão, conforme apresentado na Figura 34 (Soares, 2009).

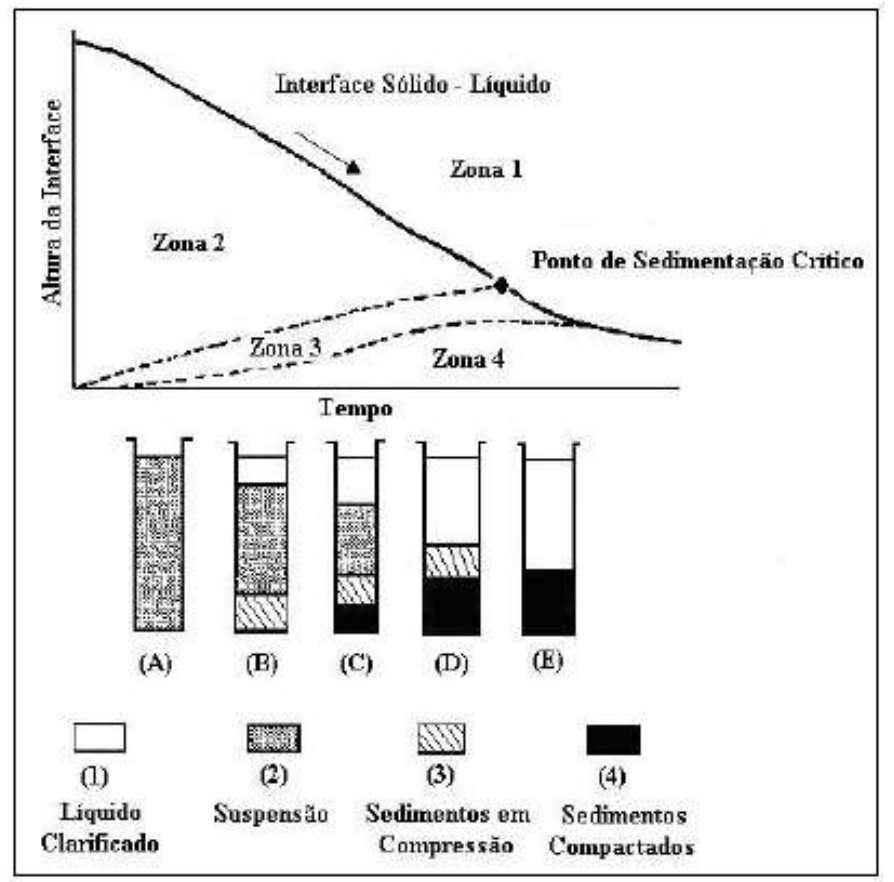

Figura 33 Zonas formadas nos testes de floculação (Soares, 2009)

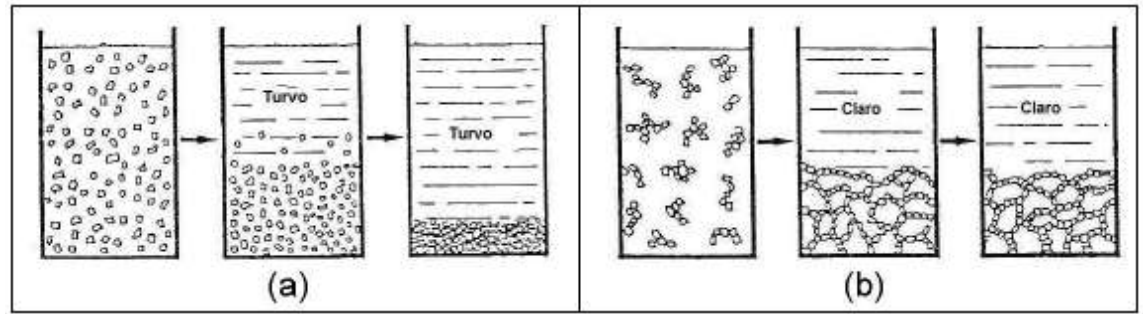

Figura 34 Processo de sedimentação em suspensões floculadas (a) e não floculadas (b). (Soares, 2009)

A turbidez foi a análise utilizada para medir a presença de sólidos na solução do sobrenadante (clarificado), que mede o grau de atenuação de intensidade que um feixe de luz sofre ao atravessá-la e esta redução se dá por absorção e espalhamento, uma vez que as partículas que provocam turbidez nas águas são 
maiores que o comprimento de onda da luz branca, devido à presença de sólidos em suspensão (Passos, 2010). As medições de turbidez foram realizadas com um turbidímetro Hach 2100P, para a quantificação da eficiência de remoção dos sólidos.

A meta de turbidez estipulada para os ensaios de floculação/sedimentação foi de 40 NTU, baseada na resolução CONAMA 357 (Silva, 2005). Este procedimento analítico foi utilizado, igualmente, para as amostras de rejeito de $\mathrm{Ni}$ e lama vermelha. A Figura 35 indica o procedimento sequencial dos testes de floculação, realizados no jar test.

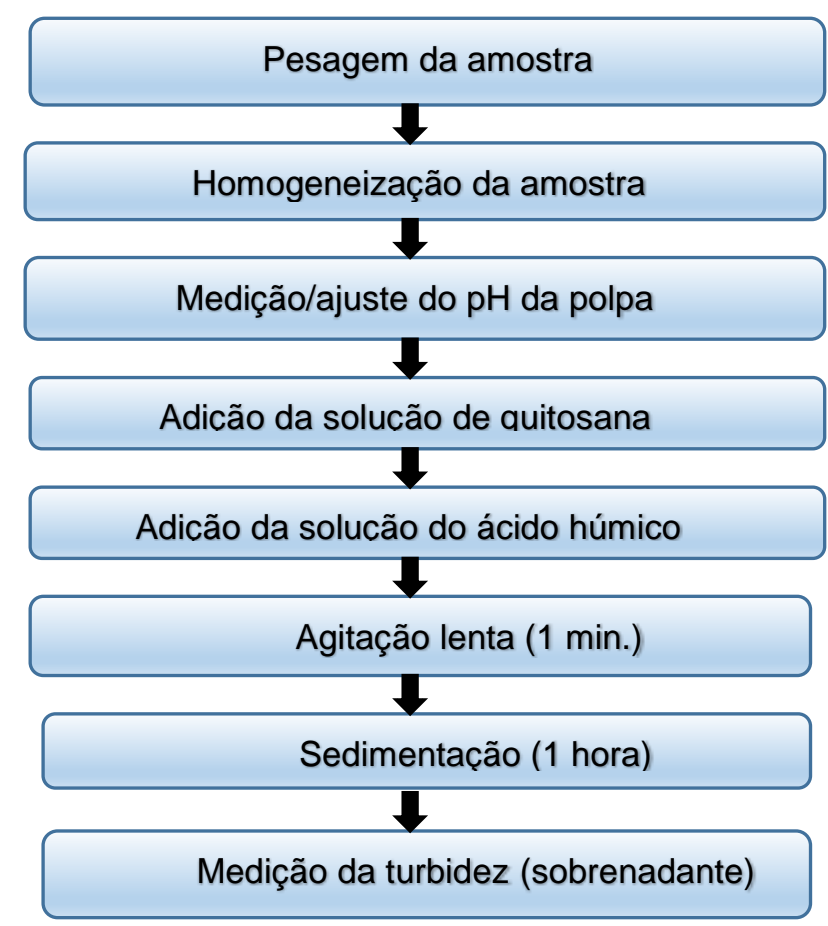

Figura 35 Diagrama dos testes de floculação para o rejeito de Ni e da lama vermelha

\subsection{Análise química da água}

A análise da água permite determinar os íons presentes na água, para avaliar a sua influência na floculação. A técnica utilizada foi a espectrometria de emissão atômica com plasma acoplado indutivamente (ICP-OES).

\subsection{Medida das cargas elétricas de superfície da quitosana}

A medição de cargas superficiais da solução de quitosana, foi realizada diretamente da solução estoque (ITEM 4.3). As soluções poliméricas foram 
divididas em várias alíquotas, as quais tiveram o seu pH ajustado ponto a ponto na faixa de $\mathrm{pH}$ de 3 a 12 com soluções de $\mathrm{HCl} 0,1 \mathrm{M}$ e $\mathrm{KOH} 0,1 \mathrm{M}$.

\subsection{Medida das cargas elétricas de superfície do ácido húmico}

Para a medição de cargas superficiais da solução de $\mathrm{AH}$, foi tomada uma alíquota da solução estoque (item 4.4) e por diluição se preparou uma solução de 100 ppm. As soluções poliméricas foram divididas em várias alíquotas, as quais tiveram o seu pH ajustado ponto a ponto na faixa de $\mathrm{pH}$ de 3 a 12 com soluções de $\mathrm{HCl} 0,1 \mathrm{M}$ e $\mathrm{KOH} 0,1 \mathrm{M}$.

\subsection{Determinação da massa molar dos polímeros}

A determinação das massas molares do ácido húmico e da quitosana é importante porque essa propriedade tem uma forte influência na adsorção das partículas. Polímeros de maior massa molar têm contato direto com as superfícies das partículas da polpa, apresentando uma cinética de adsorção maior do que com o polímero de menor massa molar, porque este penetra nos espaços intraparticulares (Theng, 2012). O equipamento utilizado na determinação da massa molar foi o Zetasizer Nano, fabricado pela Malvern Instruments e a técnica de medida utilizada foi a Static Light Scattering (SLC). 


\section{5}

\section{Planejamento experimental}

\subsection{Introdução}

Um projeto experimental permite compreender melhor o processo e determinar como as variáveis de entrada afetam uma resposta na variável de saída; ou como essas variáveis interagem entre sim, gerando entre elas uma interdependência, que altera o seu efeito individual. Os dados são analisados por métodos estatísticos, é a único abordagem para avaliar um problema que envolve dados sujeitos a erros experimentais (Wolfgang, 2005). A seguir serão apresentados alguns conceitos sobre planejamento de experimentos.

Unidade Experimental: Unidade ao qual está aplicado um único tratamento (que pode ser uma combinação de vários fatores).

Fator: É a variável independente que tem influência na variável de resposta.

\subsection{Planejamento fatorial}

Estuda o efeito de vários fatores em uma ou várias variáveis resposta e determina a combinação dos níveis de fatores em que o desempenho do processo seja melhor. O planejamento fatorial é representado como $2^{k}$, onde:

2 é o número de níveis $(-,+)$ e k é o número de fatores.

Para este estudo, foi realizado um planejamento experimental para o rejeito de $\mathrm{Ni}$ e outro para a lama vermelha, e foram considerados 5 fatores de estudo, desenvolvendo-se $32\left(2^{5}\right)$ testes experimentais para cada minério estudado.

A Tabela 4 apresenta a matriz das variáveis independentes e das interações em escala codificada, para os 32 testes do planejamento experimental que se desenvolveu tanto para o rejeito de Ni quanto para a lama vermelha. 
Tabela 4 Matriz das variáveis independentes e interações em escala codificada.

\begin{tabular}{|c|c|c|c|c|c|c|c|c|c|c|c|c|c|c|c|c|c|}
\hline TESTE & Xo & A & B & C & D & $E$ & $\mathbf{A B}$ & $\mathbf{A C}$ & $\overline{A D}$ & $\overline{\mathrm{AE}}$ & $B C$ & $\overline{B D}$ & $\overline{B E}$ & CD & $\overline{C E}$ & $\overline{\mathrm{DE}}$ & ABCDE \\
\hline 7 & 1 & -1 & -1 & -1 & -1 & -1 & 1 & 1 & 1 & 1 & 1 & 1 & 1 & 1 & 7 & 1 & 1 \\
\hline 2 & 1 & 1 & -1 & -1 & -1 & -1 & -1 & -1 & -1 & -1 & 1 & 1 & 1 & 1 & 1 & 1 & 1 \\
\hline 3 & 1 & -1 & 1 & -1 & -1 & -1 & -1 & 1 & 1 & 1 & -1 & -1 & -1 & 1 & 1 & 1 & 1 \\
\hline 4 & 1 & 1 & 1 & -1 & -1 & -1 & 1 & -1 & -1 & -1 & -1 & -1 & -1 & 1 & 1 & 1 & -1 \\
\hline 5 & 1 & -1 & -1 & 1 & -1 & -1 & 1 & -1 & 1 & 1 & -1 & 1 & 1 & -1 & -1 & 1 & 1 \\
\hline 6 & 1 & 1 & -1 & 1 & -1 & -1 & -1 & 1 & -1 & -1 & -1 & 1 & 1 & -1 & -1 & 1 & -1 \\
\hline 7 & 1 & -1 & 1 & 1 & -1 & -1 & -1 & -1 & 1 & 1 & 1 & -1 & -1 & -1 & -1 & 1 & -1 \\
\hline 8 & 1 & 1 & 1 & 1 & -1 & -1 & 1 & 1 & -1 & -1 & 1 & -1 & -1 & -1 & -1 & 1 & 1 \\
\hline 9 & 1 & -1 & -1 & -1 & 1 & -1 & 1 & 1 & -1 & 1 & 1 & -1 & 1 & -1 & 1 & -1 & 1 \\
\hline 10 & 1 & 1 & -1 & -1 & 1 & -1 & -1 & -1 & 1 & -1 & 1 & -1 & 1 & -1 & 1 & -1 & -1 \\
\hline 11 & 1 & -1 & 1 & -1 & 1 & -1 & -1 & 1 & -1 & 1 & -1 & 1 & -1 & -1 & 1 & -1 & -1 \\
\hline 12 & 1 & 1 & 1 & -1 & 1 & -1 & 1 & -1 & 1 & -1 & -1 & 1 & -1 & -1 & 1 & -1 & 1 \\
\hline 13 & 1 & -1 & -1 & 1 & 1 & -1 & 1 & -1 & -1 & 1 & -1 & -1 & 1 & 1 & -1 & -1 & -1 \\
\hline 14 & 1 & 1 & -1 & 1 & 1 & -1 & -1 & 1 & 1 & -1 & -1 & -1 & 1 & 1 & -1 & -1 & 1 \\
\hline 15 & 1 & -1 & 1 & 1 & 1 & -1 & -1 & -1 & -1 & 1 & 1 & 1 & -1 & 1 & -1 & -1 & 1 \\
\hline 16 & 1 & 1 & 1 & 1 & 1 & -1 & 1 & 1 & 1 & -1 & 1 & 1 & -1 & 1 & -1 & -1 & -1 \\
\hline 17 & 1 & -1 & -1 & -1 & -1 & 1 & 1 & 1 & 1 & -1 & 1 & 1 & -1 & 1 & -1 & -1 & 1 \\
\hline 18 & 1 & 1 & -1 & -1 & -1 & 1 & -1 & -1 & -1 & 1 & 1 & 1 & -1 & 1 & -1 & -1 & -1 \\
\hline 19 & 1 & -1 & 1 & -1 & -1 & 1 & -1 & 1 & 1 & -1 & -1 & -1 & 1 & 1 & -1 & -1 & -1 \\
\hline 20 & 1 & 1 & 1 & -1 & -1 & 1 & 1 & -1 & -1 & 1 & -1 & -1 & 1 & 1 & -1 & -1 & 1 \\
\hline 21 & 1 & -1 & -1 & 1 & -1 & 1 & 1 & -1 & 1 & -1 & -1 & 1 & -1 & -1 & 1 & -1 & -1 \\
\hline 22 & 1 & 1 & -1 & 1 & -1 & 1 & -1 & 1 & -1 & 1 & -1 & 1 & -1 & -1 & 1 & -1 & 1 \\
\hline 23 & 1 & -1 & 1 & 1 & -1 & 1 & -1 & -1 & 1 & -1 & 1 & -1 & 1 & -1 & 1 & -1 & 1 \\
\hline 24 & 1 & 1 & 1 & 1 & -1 & 1 & 1 & 1 & -1 & 1 & 1 & -1 & 1 & -1 & 1 & -1 & -1 \\
\hline 25 & 1 & -1 & -1 & -1 & 1 & 1 & 1 & 1 & -1 & -1 & 1 & -1 & -1 & -1 & -1 & 1 & -1 \\
\hline 26 & 1 & 1 & -1 & -1 & 1 & 1 & -1 & -1 & 1 & 1 & 1 & -1 & -1 & -1 & -1 & 1 & 1 \\
\hline 27 & 1 & -1 & 1 & -1 & 1 & 1 & -1 & 1 & -1 & -1 & -1 & 1 & 1 & -1 & -1 & 1 & 1 \\
\hline 28 & 1 & 1 & 1 & -1 & 1 & 1 & 1 & -1 & 1 & 1 & -1 & 1 & 1 & -1 & -1 & 1 & -1 \\
\hline 29 & 1 & -1 & -1 & 1 & 1 & 1 & 1 & -1 & -1 & -1 & -1 & -1 & -1 & 1 & 1 & 1 & 1 \\
\hline 30 & 1 & 1 & -1 & 1 & 1 & 1 & -1 & 1 & 1 & 1 & -1 & -1 & -1 & 1 & 1 & 1 & -1 \\
\hline 31 & 1 & -1 & 1 & 1 & 1 & 1 & -1 & -1 & -1 & -1 & 1 & 1 & 1 & 1 & 1 & 1 & -1 \\
\hline 32 & 1 & 1 & 1 & 1 & 1 & 1 & 1 & 1 & 1 & 1 & 1 & 1 & 1 & 1 & 1 & 1 & 1 \\
\hline
\end{tabular}

O desenho fatorial $2^{k}$ assume uma relação linear entre as variáveis independentes e a variável de resposta. Se o modelo se ajusta aos dados experimentais como modelo linear, então deve prever projetar corretamente todos os pontos, incluindo o ponto central. Os testes no ponto central dão uma estimativa de efeito de curvatura, indicando que os dados não vão se ajustar ao modelo linear. (Wolfgang, 2005).

A análise de variância, mede-se a significância dos efeitos sobre os desenhos experimentais, e determina quais fatores de um grupo particular de variáveis são significativos (Ayres, Torres e Ponce, 2000). 
E nas Tabelas 5 e 6 apresentam os valores atribuídos para as variáveis (fatores) para o planejamento do rejeito de $\mathrm{Ni}$ e para a lama vermelha respectivamente. Os dados de cada planejamento experimental foram ajustados de acordo aos resultados que se obteve da realização de pre-testes.

Tabela 5 Fatores do Planejamento experimental do rejeito de Ni.

\begin{tabular}{|l|c|c|c|c|}
\cline { 2 - 5 } \multicolumn{1}{c|}{} & Fator & - & 0 & + \\
\hline Concentração de sólidos (\%) & A & 1 & 1,5 & 2 \\
\hline Dosagem de quitosana (g/t) & B & 20 & 60 & 100 \\
\hline Dosagem de ácido húmico (g/t) & C & 1,5 & 3,25 & 5 \\
\hline Velocidade de agitação rápida (rpm) & D & 175 & 225 & 275 \\
\hline Tempo de agitação rápida (min) & E & 1 & 2 & 3 \\
\hline
\end{tabular}

Tabela 6 Fatores do Planejamento experimental da lama vermelha.

\begin{tabular}{|l|c|c|c|c|}
\cline { 2 - 5 } \multicolumn{1}{c|}{} & Fator & - & 0 & + \\
\hline Concentração de sólidos (\%) & A & 0,5 & 0,75 & 1 \\
\hline Dosagem de quitosana (g/t) & B & 650 & 975 & 1300 \\
\hline Dosagem de ácido húmico (g/t) & C & 8 & 12 & 16 \\
\hline Velocidade de agitação rápida (rpm) & D & 175 & 225 & 275 \\
\hline Tempo de agitação rápida (min) & E & 1 & 2 & 3 \\
\hline
\end{tabular}

\subsubsection{Decodificação do modelo matemático}

Depois de obter para cada teste uma resposta da variável dependente (turbidez), e por uma sequência de cálculos estatísticos se determinou o modelo matemático, no qual só é possível substituir as variáveis com dados codificados, porém, foi preciso decodificar o modelo matemático para poder substituir as variáveis do modelo com valores numéricos, que estejam dentro dos parâmetros estabelecidos do planejamento experimental e para realizar a otimização de parâmetros.

No modelo matemático, os valores das variáveis estão representados por (1) e (1). Para decodificar, o cálculo do termo independente e do termo linear são mostradas nas equações da Tabela 7. 
Tabela 7 Equações para determinar os coeficientes do modelo decodificado.

\begin{tabular}{|c|c|}
\hline Para determinar: & Equação \\
\hline Termo independente & $a_{0}=b_{0}-\sum_{j=1}^{k} b_{j} \varepsilon_{j}+\sum_{i, j=1}^{k} b_{i j} \varepsilon_{i j}$ \\
\hline Termo linear & $a_{j} Z_{j}=b_{j} / \Delta Z_{j}-\sum_{j, i}^{k} b_{i j} * E_{i} / \Delta Z_{j}$ \\
\hline
\end{tabular}

\subsection{Planejamento composto central}

É o mais utilizado para otimizar modelos de segundo ordem, pode ser construído a partir de um planejamento fatorial $2^{k}$ completo ou fracionado $\left(2^{k-p}\right)$, inclui um conjunto de pontos sobre os eixos (chamados pontos estrela), que em conjunto com o ponto central (normalmente repetida), permite estimar termos quadráticos puros, como se observa na Figura 36 (Gutiérrez e la Vara, De, 2008).

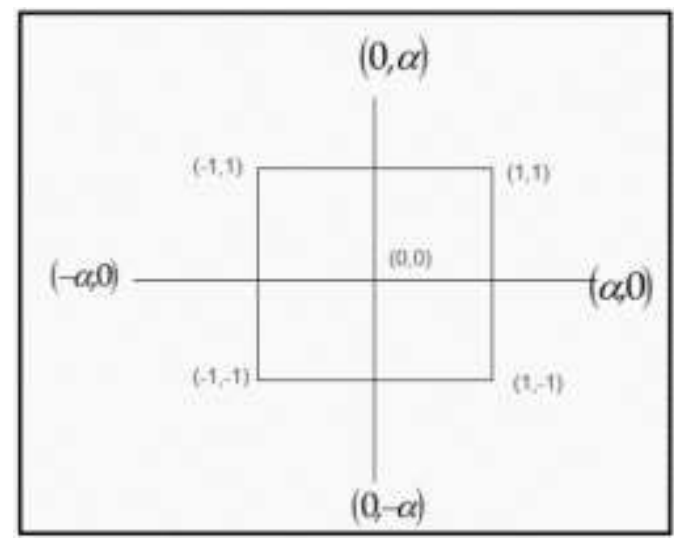

Figura 36 Desenho composto central (Gutiérrez e De la Vara, 2008)

O valor de $\alpha$ para alcançar a conversão do desenho rotativo depende do número de pontos na parte do desenho factorial: $\alpha=\left(2^{k}\right)^{1 / 4}$, onde $\alpha$ é o número de pontos na parte do desenho factorial, assim o valor de $\alpha$, para cada fator (Tabela 8). 
Tabela 8 Valores de $\alpha$ segundo o número de fatores (Gutiérrez e De la Vara, 2008)

\begin{tabular}{|c|c|}
\hline Fatores ou variáveis & $\boldsymbol{\alpha}$ \\
\hline 2 & 1,4142 \\
\hline 3 & 1,6818 \\
\hline 4 & 2,0000 \\
\hline 5 & 2,3784 \\
\hline
\end{tabular}

O planejamento estrela aponta valores $-2^{k / 4} e+2^{k / 4}$, que estão fora dos pontos da faixa eincluem fins exploratórios.

Para a decodificação da matriz e substituição dos valores experimentais, realizase o cálculo com base na Equação (18) (Palacios, 2013):

$$
X i=\frac{V i-a}{b}
$$

Onde:

$\mathrm{Vi}=$ nível de variável real escolhida

$\mathrm{a}=$ valor da variável no ponto central

$\mathrm{b}=$ amplitude do valor real

\subsection{Planejamento simplex: (modelo de primeira ordem)}

O cálculo dos parâmetros de otimização para uma minimização de turbidez é determinado pelo modelo simplex, que é definido por um conjunto de $(k+1)$ pontos equidistantes em dimensões de k. No espaço de uma dimensão a uma variável, o modelo simplex é uma linha reta para duas variáveis, um triângulo equilátero para três variáveis, um tetraedro regular (4 pontos) para quatro variáveis, e assim sucessivamente (Wolfgang, 2005).

Para projetar os pontos experimentais, deve-se encontrar o seguinte: a) Centro de gravidade (ou centróide): o centro de gravidade de todos os pontos do poliedro, exceto o valor que está fora da otimização, e é definido pela Equação (19):

$$
Z_{(c g)}=1 /{ }_{k}\left(\sum_{j=1}^{K+1} Z j-Z_{(p i o r)}\right)
$$

Onde:

$Z^{(\mathrm{cg})}$ é o vetor que define as coordenadas do centro de gravidade. 
b) Ponto refletido, definido pela Equação (20):

$$
Z j_{(r)}=Z j_{(c g)}+\alpha\left(Z_{(c g)}-Z_{(p i o r)}\right)
$$

Onde:

$$
\begin{aligned}
& \alpha=\text { constante positiva, e o valor recomendado é } 1 \\
& Z_{j}^{(r)}=\text { vetor que define as coordenadas do ponto refletido. }
\end{aligned}
$$

Para facilitar o uso prático da matriz simplex, os valores numéricos foram calculados para seis variáveis (Wolfgang, 2005), conforme apresentado na Figura 37:

$$
X=\left|\begin{array}{rrrrr}
0.5 & 0.289 & 0.204 & 0.158 & 0.129 \\
-0.5 & 0.289 & 0.204 & 0.158 & 0.129 \\
0 & -0.578 & 0.204 & 0.158 & 0.129 \\
0 & 0 & -0.612 & 0.158 & 0.129 \\
0 & 0 & 0 & -0.632 & 0.129 \\
0 & 0 & 0 & 0 & -0.645
\end{array}\right|
$$

Figura 37 Matrix simplex desenvolvido para seis variáveis (Wolfgang, 2005) 
6

\section{Discussão e resultados}

\subsection{Análise química da água}

A Tabela 9 apresenta os resultados da análise química da água da torneira, para esta análise se realizaram oito amostragens em diferentes dias. No ANEXO 1 , encontram-se todos os resultados, foram importantes determinar os íons presentes na água para estudar se teve influência na geração de pontes na adsorção com polímero-partícula.

Tabela 9 Análise química da água.

\begin{tabular}{|c|c|}
\hline Espécies & $\begin{array}{c}\text { Concentração } \\
\text { (mg/L) }\end{array}$ \\
\hline $\mathrm{Cl}^{-}$ & 5,8 \\
\hline $\mathrm{SO}^{-2}$ & 6,2 \\
\hline $\mathrm{NO}^{-3}$ & 1,0 \\
\hline $\mathrm{Al}^{+3}$ & 0,17 \\
\hline $\mathrm{Ca}^{+2}$ & 5,4 \\
\hline $\mathrm{Fe}^{+2}$ & 0,27 \\
\hline $\mathrm{Mg}^{+2}$ & 1,2 \\
\hline $\mathrm{K}^{+1}$ & 2,6 \\
\hline $\mathrm{Na}^{+1}$ & 7,0 \\
\hline
\end{tabular}

\subsection{Espectro de infravermelho da quitosana da SigmaAldrich}

O espectro de absorção de infravermelho na quitosana, mostrado na Figura 38 , apresenta bandas características da amida, a região $3483 \mathrm{~cm}^{-1}$ o estiramento $\mathrm{N}-\mathrm{H}$ ocorre em aminas primárias, na região $2875 \mathrm{~cm}^{-1}$ a banda de estiramento C$\mathrm{H}$ de um alcano, as regiões $1655 \mathrm{~cm}^{-1}$ e $1589 \mathrm{~cm}^{-1}$, geram umas fortes bandas vibracionais de dobramento $\mathrm{N}-\mathrm{H}$ de amidas primárias. A região $1377 \mathrm{~cm}^{-1}$ tem uma adsorção de dobramento característica dos grupo metila $\mathrm{CH}_{3}$, as regiões de 1302 $\mathrm{cm}^{-1}$ e $1201 \mathrm{~cm}^{-1}$ são característicos das aminas aromáticas da adsorção de estiramento $\mathrm{C}-\mathrm{N}$; a região $1159 \mathrm{~cm}^{-1}$ é atribuído as aminas alifáticas da adsorção 
de estiramento C-N e a região $667 \mathrm{~cm}^{-1}$ gera uma banda de dobramento $\mathrm{N}-\mathrm{H}$ de amida primária (Araújo e Fascio, 2004; Paiva et al., 2010)

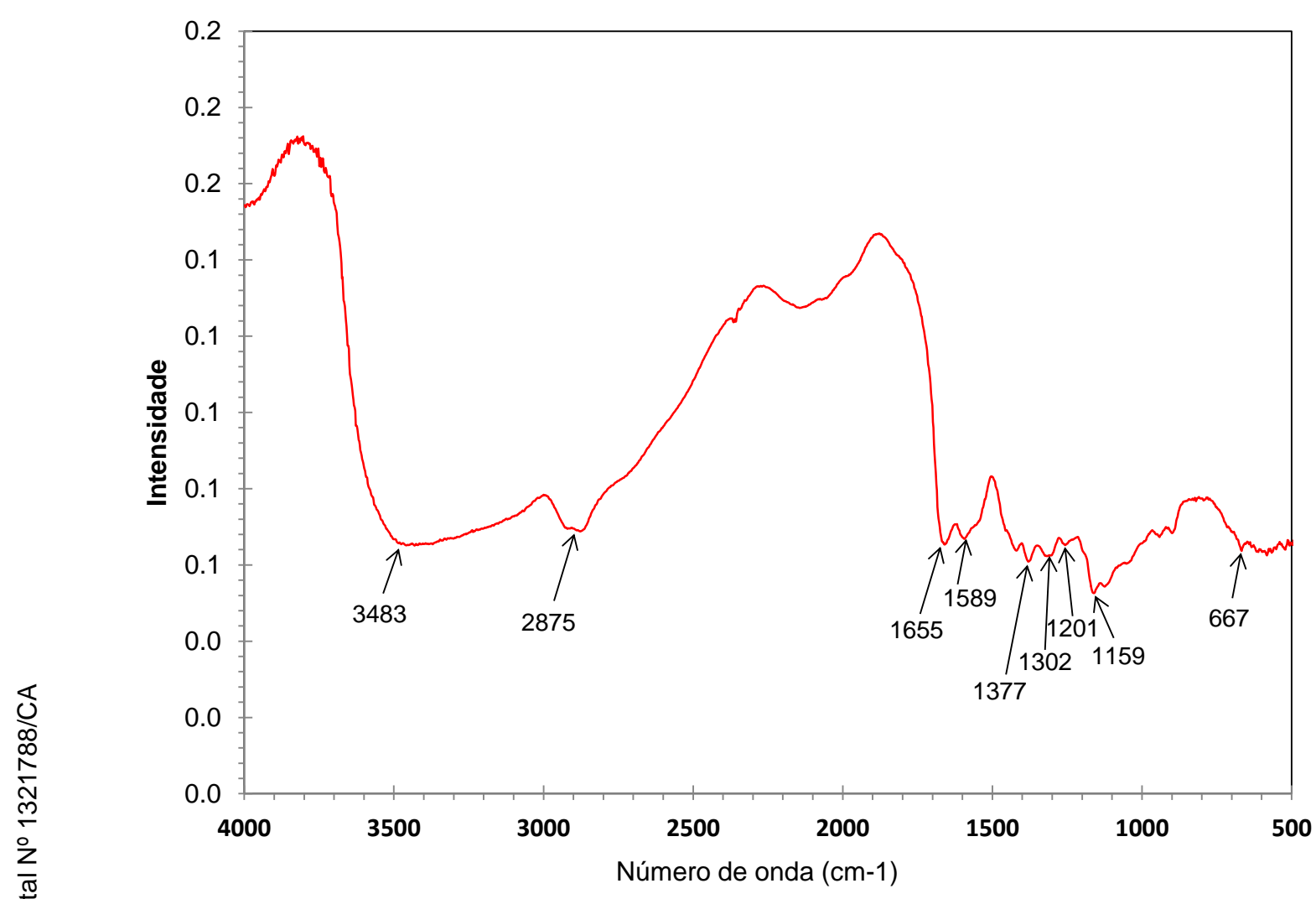

Figura 38 Espectro de infravermelho da quitosana

\subsection{Espectro de infravermelho do AH (SigmaAldrich)}

O espectro de absorção de infravermelho do AH é mostrado na Figura 39: as regiões $3687 \mathrm{~cm}^{-1}$ e $3626 \mathrm{~cm}^{-1}$ são características as bandas de estiramento $\mathrm{O}-\mathrm{H}$ dos grupos fenóis; a região de $2357 \mathrm{~cm}^{-1}$ é o estiramento $\mathrm{O}-\mathrm{H}$ e em geral sobrepõe as absorções $\mathrm{C}-\mathrm{H}$ características dos ácidos carboxílicos. Na região $1686 \mathrm{~cm}^{-1}$ é a banda de estiramento $\mathrm{O}-\mathrm{H}$ e em geral se sobrepõe no grupo $\mathrm{C}=\mathrm{O}$, característico dos ácidos carboxílicos; a região $1558 \mathrm{~cm}^{-1}$ é atribuída a banda de estiramento de anéis aromáticos $\mathrm{C}=\mathrm{C}$ e a região1452 $\mathrm{cm}^{-1}$ é atribuída à presença do grupo metila $\mathrm{CH}_{3}$. As regiões de 1211, 11191053 e 924 cm${ }^{-1}$ são atribuídas a uma vibração de estiramento C-O, para definir uma estrutura primária, secundaria ou terciária de um álcool. Finalmente, as regiões de $806 \mathrm{~cm}^{-1}$ e $692 \mathrm{~cm}^{-1}$ referemse ao dobramento $=\mathrm{C}-\mathrm{H}$ fora do plano e são características dos anéis aromáticos. (Kelley e Stevenson, 1996; Paiva et al., 2010) 


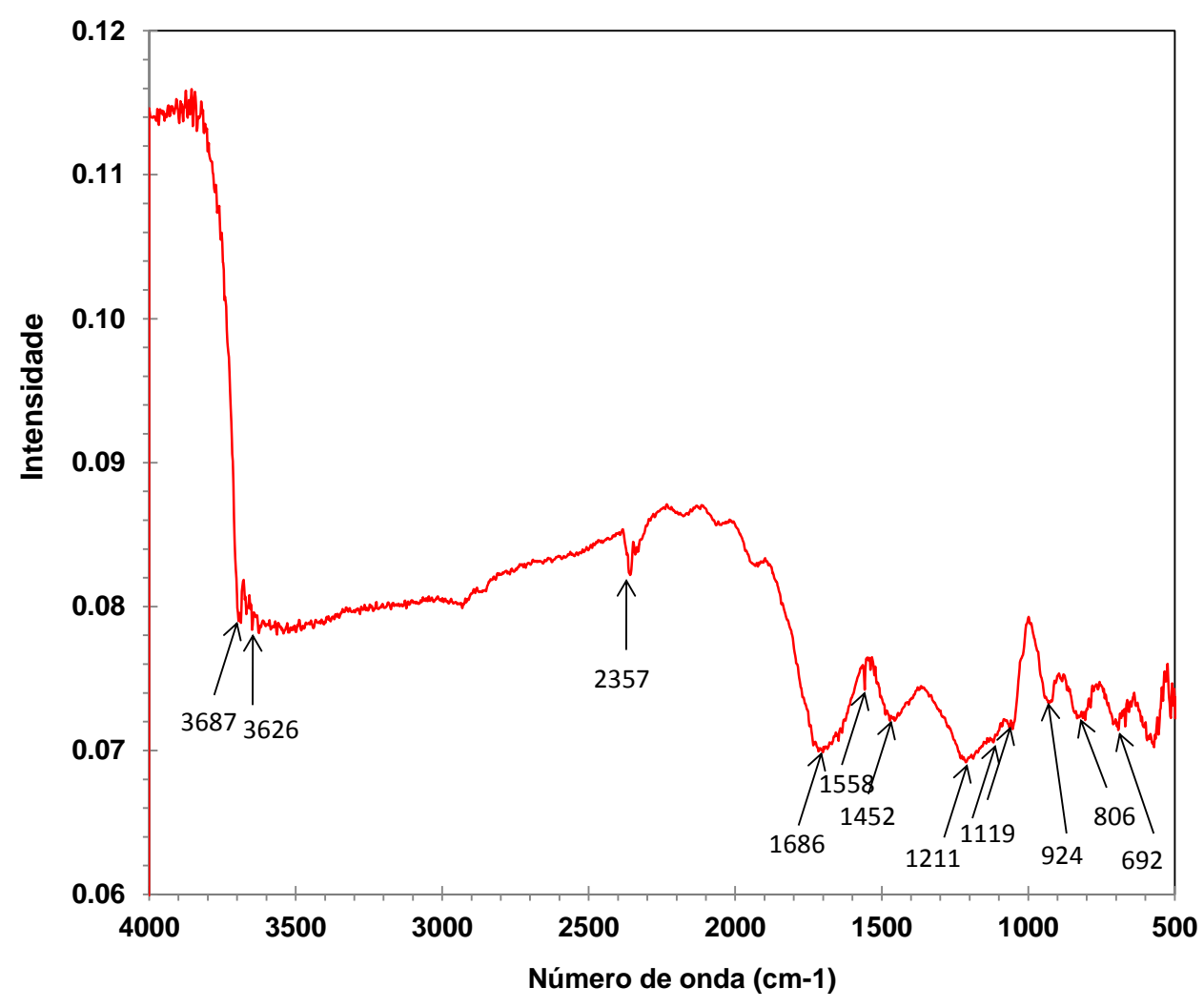

Figura 39 Espectro de infravermelho do $\mathrm{AH}$ (Aldrich)

\subsection{Espectro de infravermelho do AH do carvão mineral (Puc-Rio)}

O espectro de absorção de infravermelho do $\mathrm{AH}$ é mostrado na Figura 40: as bandas de estiramento das regiões $3400 \mathrm{~cm}^{-1}, 3300 \mathrm{~cm}^{-1}$ e $3150 \mathrm{~cm}^{-1}$ são características as bandas de estiramento $\mathrm{O}-\mathrm{H}$ dos grupos álcoois fenóis; a região de $2911 \mathrm{~cm}^{-1}$ é o estiramento $\mathrm{C}-\mathrm{H}$ características de compostos alifáticos. $\mathrm{Na}$ região $1707 \mathrm{~cm}^{-1}$ é a banda de estiramento do grupo $\mathrm{C}=\mathrm{O}$, característico dos ácidos carboxílicos e carbonilicos; a região $1605 \mathrm{~cm}^{-1}$ e $1526 \mathrm{~cm}^{-1}$ é atribuída a banda de estiramento de anéis aromáticos $\mathrm{C}=\mathrm{O}$, a região1438 $\mathrm{cm}^{-1}$ é atribuída à deformação $\mathrm{C}-\mathrm{H}$ dos grupos alifáticos, a região de $1335 \mathrm{~cm}^{-1}$ é o estiramento assimétrico do grupo COO- e do grupo $\mathrm{N}=\mathrm{O}$, na região $1247 \mathrm{~cm}^{-1}$ é uma vibração de estiramento $\mathrm{C}-\mathrm{O}$, para definir uma estrutura primária, secundaria ou terciária de um álcool e a banda $761 \mathrm{~cm}^{-1}$ refe-se ao dobramento $=\mathrm{C}-\mathrm{H}$ fora do plano e são características dos anéis aromáticos. (Garces, 2015) 


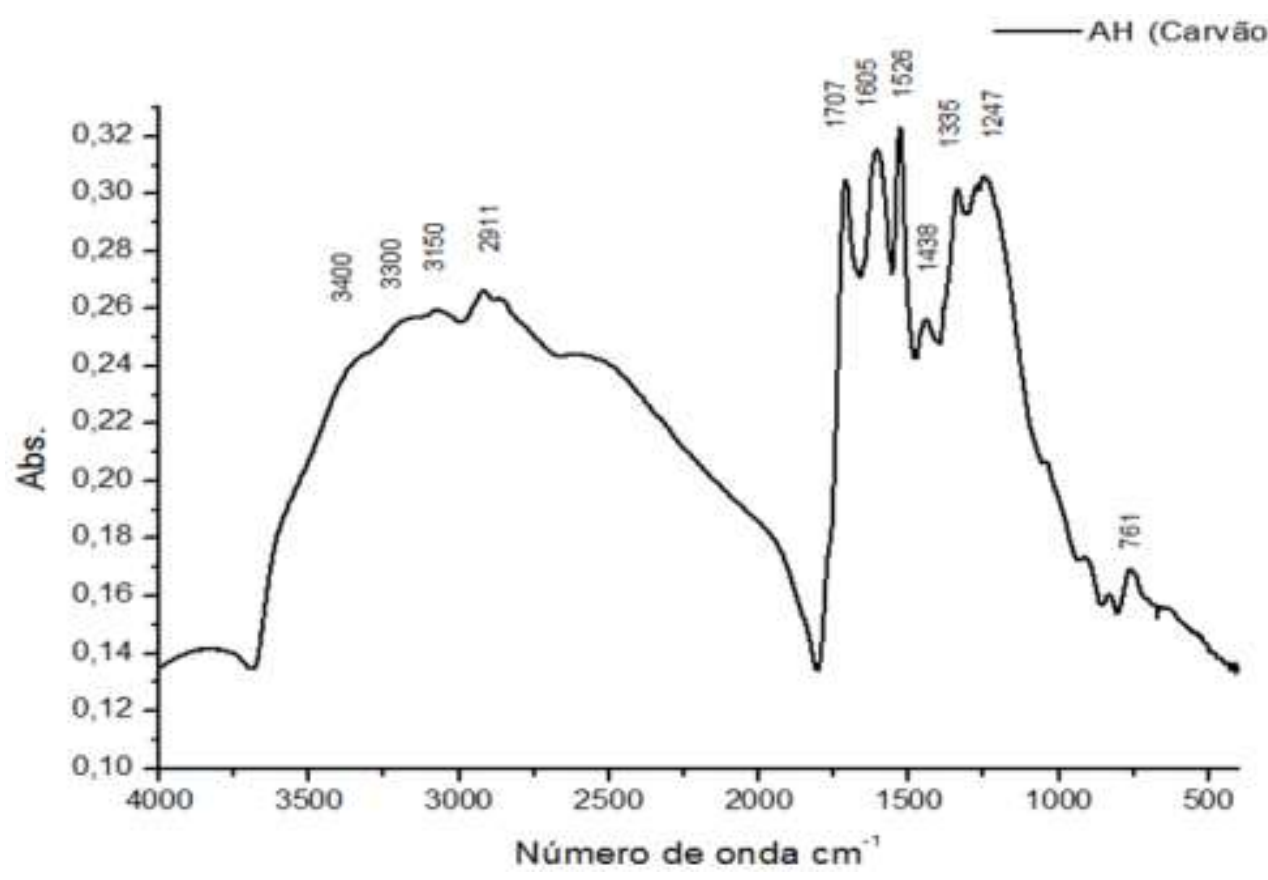

Figura 40 Espectro de infravermelho do $\mathrm{AH}$ carvão mineral (Puc-Rio) (Garces, 2015)

\subsection{Espectro de infravermelho do AH do coque mineral (Puc-Rio)}

O espectro de absorção de infravermelho do AH é mostrado na Figura 41. A banda em 3453 cm-1 é característica de estiramentos de grupos O-H em ligação de hidrogênio; em $1632 \mathrm{~cm}-1$ apresenta estiramentos $\mathrm{C}=\mathrm{C}$ de grupos aromáticos. Em 1384 cm-1 existe um pico muito forte, é característico de deformação de O-H, ligação $\mathrm{CH} 3$ ou estiramento C-O. (Andrade, 2014) 


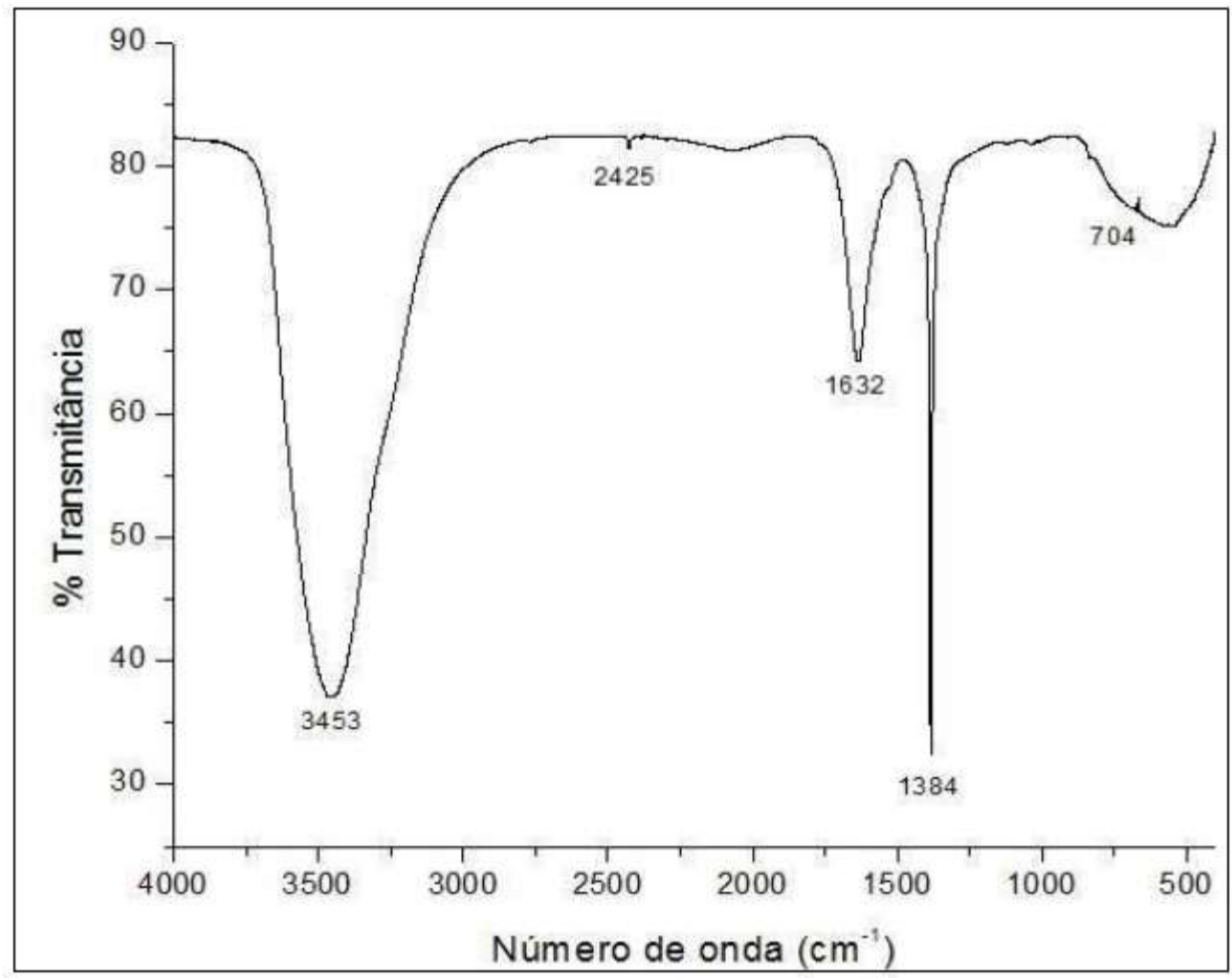

Figura 41 Espectro de infravermelho do $\mathrm{AH}$ do coque mineral (Puc-Rio) (Andrade, 2014)

\subsection{Espectro de infravermelho do AH do Suwanne River (IHSS)}

O espectro de absorção de infravermelho do AH é mostrado na Figura 42: na região $3398 \mathrm{~cm}^{-1}$ é característico da banda de estiramento $\mathrm{C}=\mathrm{N}$ do grupo amina; a região de $2965 \mathrm{~cm}^{-1}$ é a presença dos grupos carboxílicos COO- e em geral sobrepõe as absorções $\mathrm{C}-\mathrm{H}$ características dos ácidos carboxílicos. $\mathrm{Na}$ região 1720 e $1620 \mathrm{~cm}^{-1}$ são bandas de estiramento do grupo carbonilo $\mathrm{C}=\mathrm{O}$, característico dos ácidos carboxílicos; a região $1387 \mathrm{~cm}^{-1}$ é atribuída a banda de estiramento dos grupos carboxílicos COO- e a região $1204 \mathrm{~cm}^{-1}$ é atribuída é atribuída a uma vibração de estiramento C-O, para definir uma estrutura primária, secundaria ou terciária de um álcool. Finalmente, as regiões de $775 \mathrm{~cm}^{-1}$ e 590 $\mathrm{cm}^{-1}$ referem-se ao dobramento do grupo amina N-H. (IHSS, 2016) 


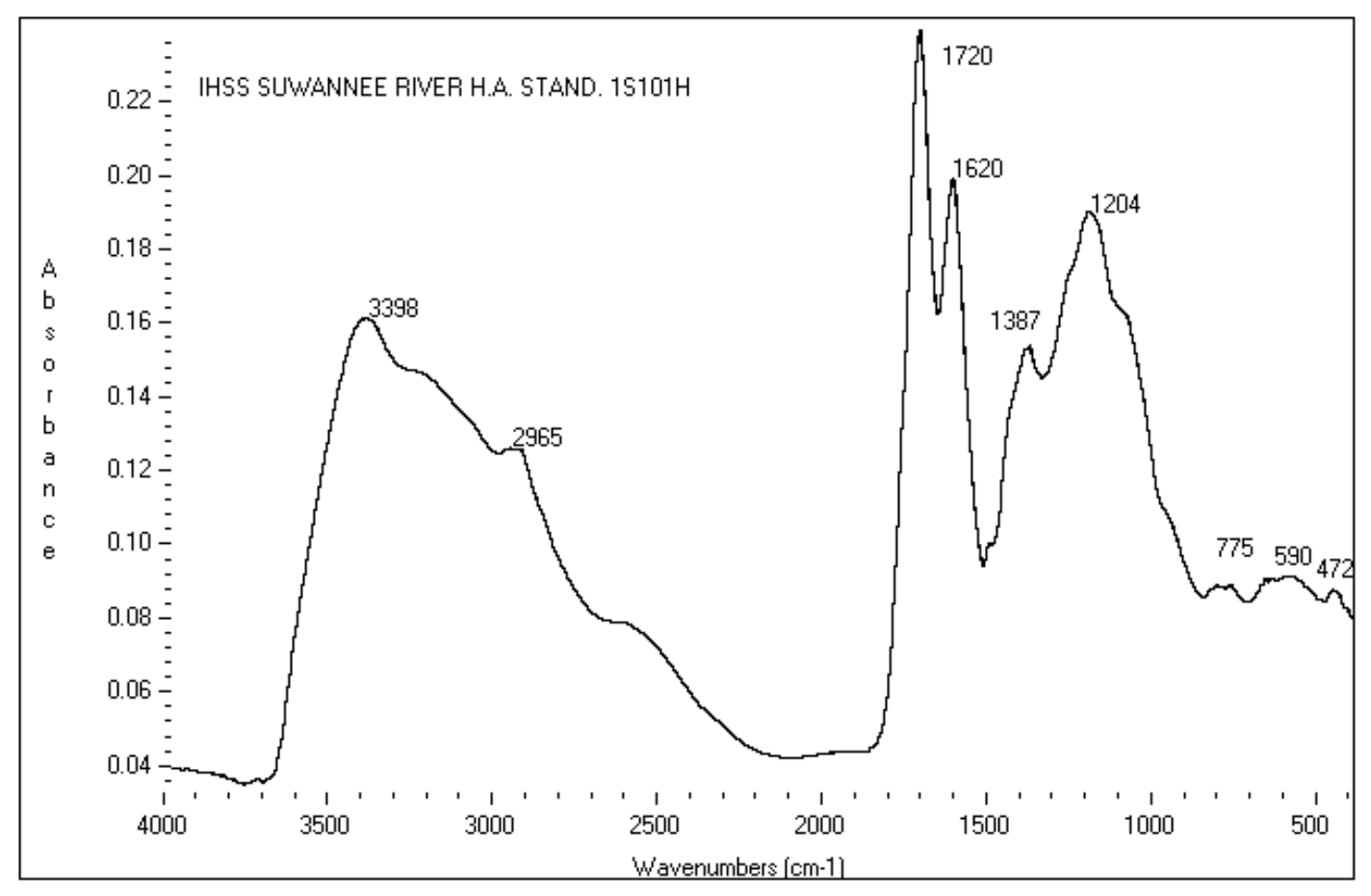

Figura 42 Espectro de infravermelho do AH do Suwanne River (IHSS)

\subsection{Espectro de infravermelho do AH do Pahokee Peat Standard} (IHSS)

O espectro de absorção de infravermelho do AH é mostrado na Figura 43: na região $3340 \mathrm{~cm}^{-1}$ é característico da banda de estiramento $\mathrm{C}=\mathrm{N}$ do grupo amina; a região de $2922 \mathrm{~cm}^{-1}$ é a presença dos grupos carboxílicos COO- e em geral sobrepõe as absorções $\mathrm{C}-\mathrm{H}$ características dos ácidos carboxílicos. $\mathrm{Na}$ região 1717 e $1617 \mathrm{~cm}^{-1}$ são bandas de estiramento do grupo carbonilo $\mathrm{C}=\mathrm{O}$, característico dos ácidos carboxílicos; a região $1384 \mathrm{~cm}^{-1}$ é atribuída a banda de estiramento dos grupos carboxílicos COO- e a região $1219 \mathrm{~cm}^{-1}$ é atribuída é atribuída a uma vibração de estiramento C-O, para definir uma estrutura primária, secundaria ou terciária de um álcool. Finalmente, as regiões de $770 \mathrm{~cm}^{-1}$ e 670 $\mathrm{cm}^{-1}$ referem-se ao dobramento do grupo amina N-H. (IHSS, 2016) 


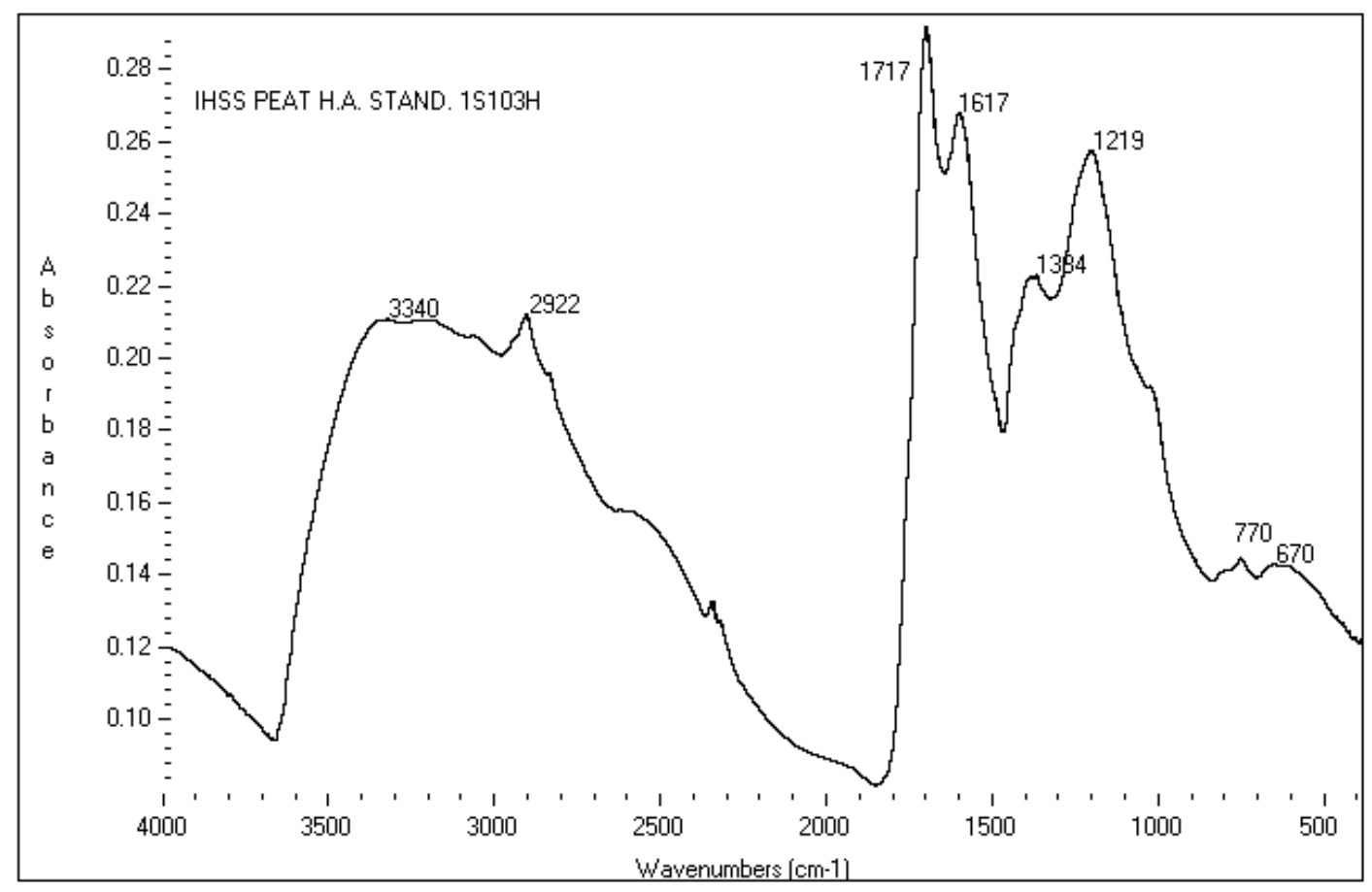

Figura 43 Espectro de infravermelho do $\mathrm{AH}$ do Pahokee Peat Standard (IHSS)

\subsection{Massa molar da quitosana e do ácido húmico}

A representação gráfica da Figura 44 e 45, conhecida como Debye Plot, apresenta os resultados da massa molar da quitosana e do ácido húmico respectivamente, que é equivalente à projeção na intercessão da abcissa do inverso do coeficiente linear da reta gerada $(\mathrm{KC} / \mathrm{RoP}=1 / \mathrm{Mw})$. A massa molar calculada para a quitosana foi de 232 kDa e para o ácido húmico foi de 25,1 kDa. O que reflete que a quitosana tem uma influencia na adsorção bem maior, por ter uma massa molar nove vezes maior do que do ácido húmico. 


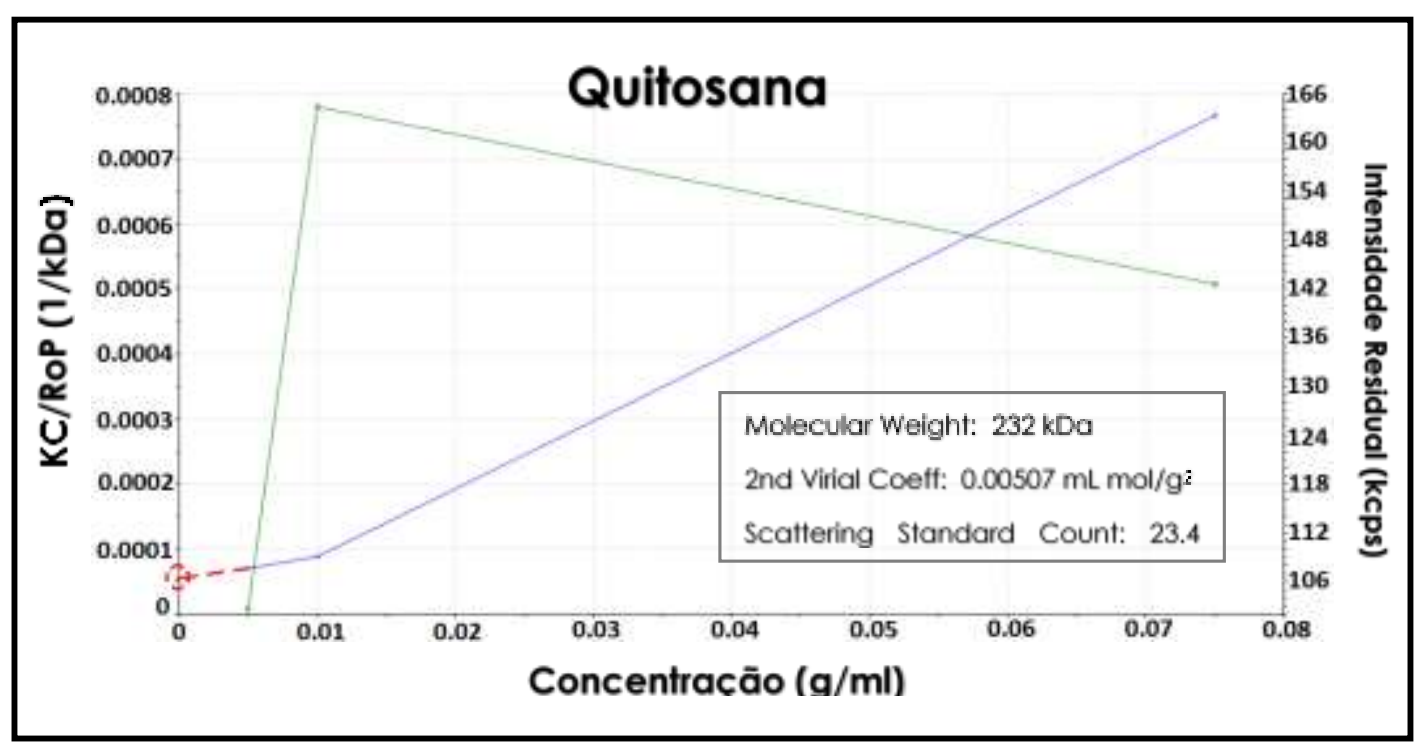

Figura 44 Determinação da massa molar da quitosana

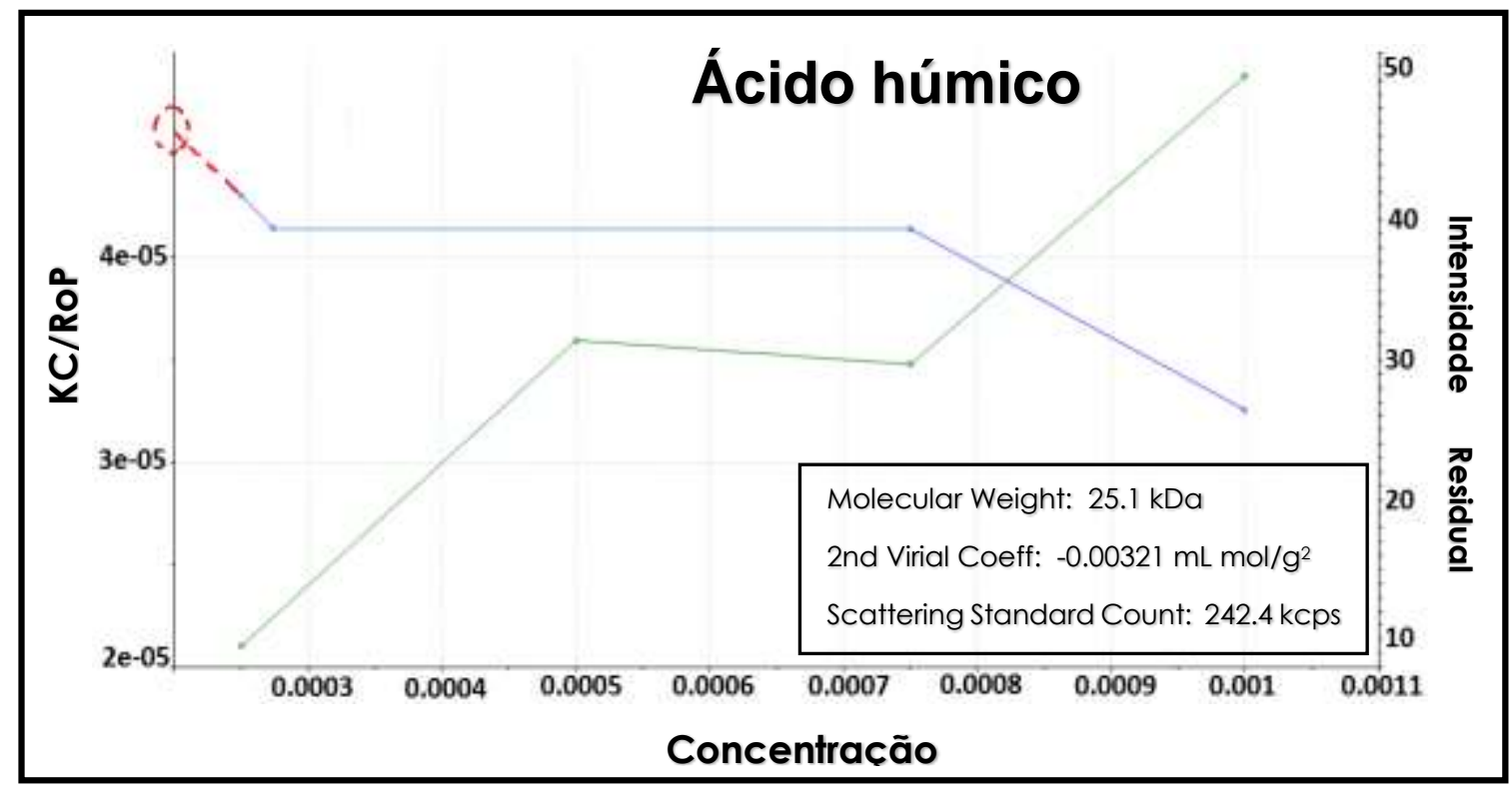

Figura 45 Determinação da massa molar do ácido húmico

\subsection{Caracterização do rejeito de $\mathrm{Ni}$}

\subsubsection{Análise Química}

A Tabela 10 apresenta os resultados de análise química para o rejeito de $\mathrm{Ni}$, e a Tabela 11 apresenta os resultados de picnometria e umidade. Em ANEXO 2 encontra-se os dados do cálculo da densidade. 
Tabela 10 Análise química do rejeito de $\mathrm{Ni}$.

\begin{tabular}{|c|c|}
\hline Elemento & Concentração (\%) \\
\hline $\mathrm{Al}$ & 2,4 \\
\hline $\mathrm{Si}$ & 43,3 \\
\hline $\mathrm{Ca}$ & 3,7 \\
\hline $\mathrm{Mg}$ & 9,0 \\
\hline $\mathrm{Fe}$ & 13,9 \\
\hline $\mathrm{Na}$ & 6,8 \\
\hline $\mathrm{Ni}$ & 0,29 \\
\hline $\mathrm{Cu}$ & 0,03 \\
\hline $\mathrm{S}$ total & 1,0 \\
\hline
\end{tabular}

Tabela 11 Densidade e umidade do rejeito de Ni.

\begin{tabular}{|l|c|}
\hline \multicolumn{1}{|c|}{ Resultado } & Rejeito de $\mathbf{~ N i}$ \\
\hline Densidade real $\left(\mathrm{kg} / \mathrm{m}^{3}\right) \pm 2.10^{-6} \mathrm{~kg}$ & 2.097 \\
\hline Umidade (\%) & 1,2 \\
\hline
\end{tabular}

\subsubsection{Análise Granulométrica}

No rejeito de $\mathrm{Ni}$ verificou-se a distribuição granulométrica. Conforme a Figura 46, apresenta uma granulometria fina passante média de $d(0,1)=2,1 \mu \mathrm{m}$, $d(0,5)=9,5 \mu \mathrm{m}$ e $d(0,9)=55 \mu \mathrm{m}$, o que reflete a presença de colóides na polpa de $\mathrm{Ni}$, numa proporção aproximada de 10\% (volume). No ANEXO 3 estão os dados de tamanho de partícula $(\mu \mathrm{m})$.

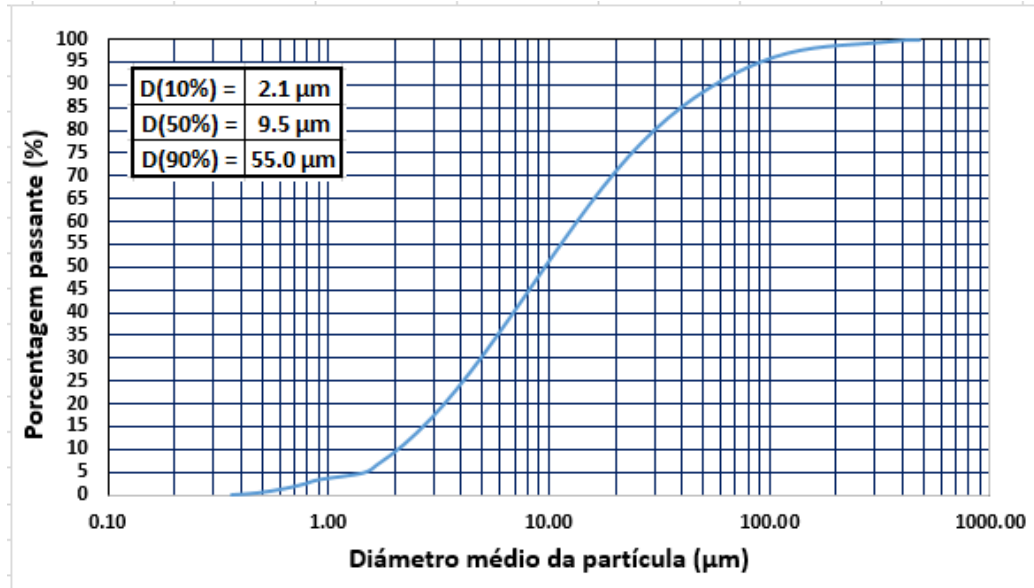

Figura 46 Distribuição granulométrica do rejeito de $\mathrm{Ni}$ 


\subsubsection{Difração de Raios X}

$\mathrm{Na}$ amostra de rejeito de níquel foram identificados picos de dolomita, quartzo e sepiolita, de menor intensidade devido à sua baixa concentração na amostra natural. Como fonte de Fe foi possível identificar a pirita e magnetita em pequena quantidade; foram também identificados minerais fonte de $\mathrm{Mg}$, como o talco, hornblenda e caulinita, com picos de maior intensidade; pequenas quantidades de vermiculita e outros argilominerais também podem estar presentes na amostra. (Figura 47).

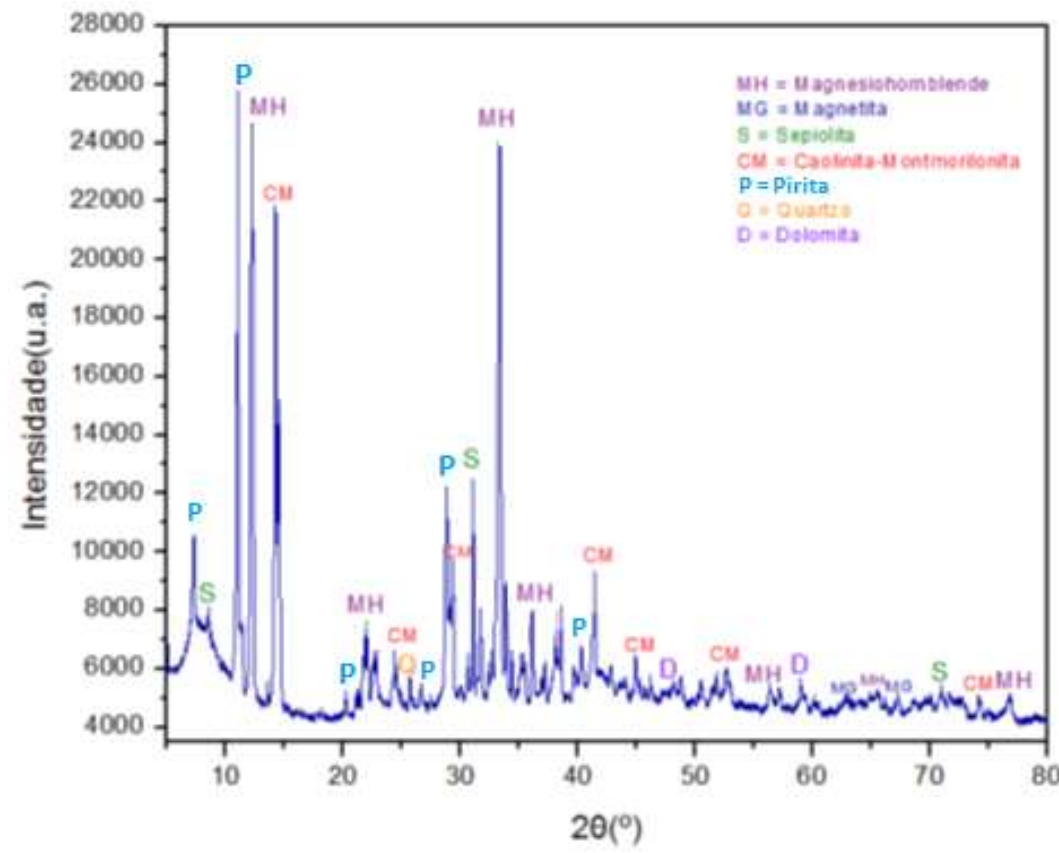

Figura 47 Espectro de DRX para o rejeito de $\mathrm{Ni}$

\subsubsection{Microscopia Eletrônica de Varredura}

A micrografia das partículas finas $(-20 \mu \mathrm{m})$, de rejeito de níquel apresentadas na Figura 48, apresenta como característica principal uma morfologia lamelar lisa e em blocos. Para avaliar a força de agregação das partículas, realizaram-se testes de floculação em função do pH. Na Figura 49, mostra-se a micrografía da floculação da polpa em $\mathrm{pH} 5$, onde é possível visualizar partículas de maior tamanho, possivelmente de agregados formados pelo processo de floculação, o que não é refletido na Figura 50, com a floculação realizada em pH 10, que apresenta uma maior dispersão de partículas, sem agregação evidente. 


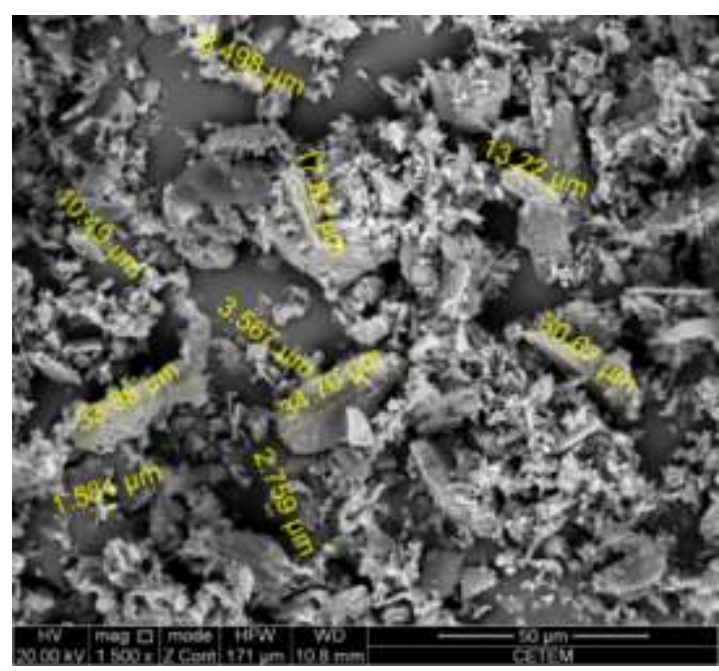

Figura 48 Micrografia das partículas de rejeito de Ni $(-20 \mu \mathrm{m})$

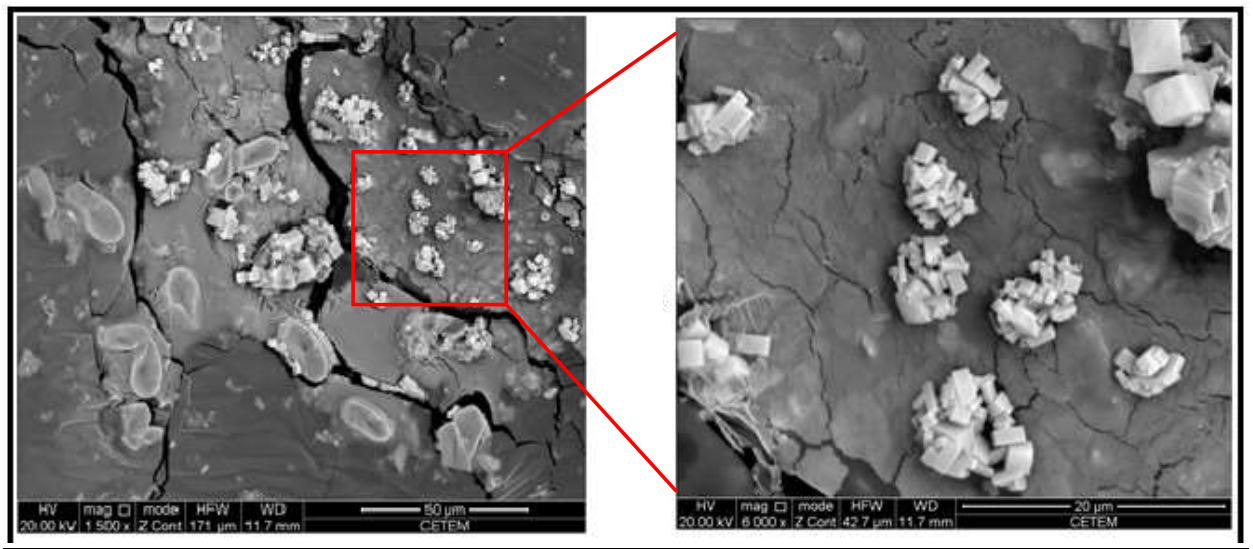

Figura 49 Micrografias das partículas de rejeito de Ni $(-20 \mu \mathrm{m})$, polpa em pH 5

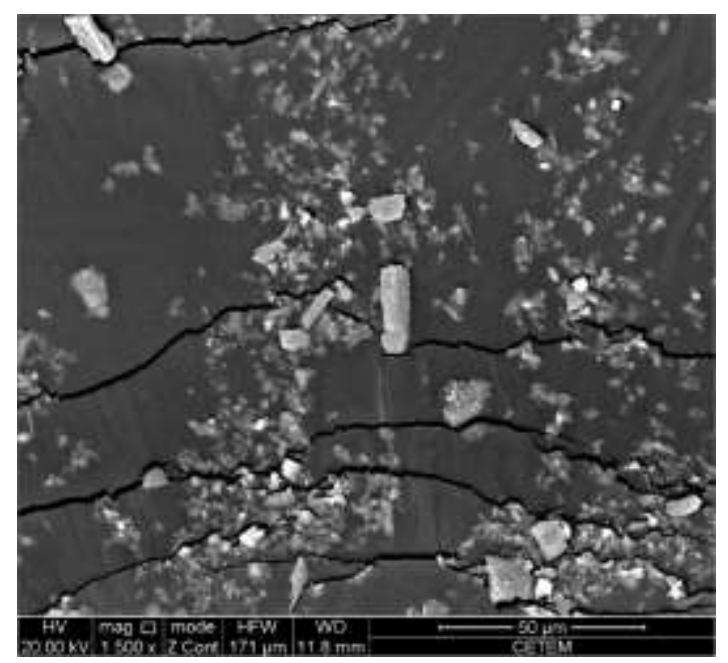

Figura 50 Micrografia das partículas de rejeito de $\mathrm{Ni}(-20 \mu \mathrm{m})$, polpa em $\mathrm{pH}$ 10 


\subsubsection{Interação eletrostática}

As medidas do potencial zeta da quitosana, do ácido húmico e do rejeito de Ni são mostradas na Figura 51, o ácido húmico apresenta um potencial negativo na faixa de $\mathrm{pH}$ de 3 para 12, em pH de 3 a 5 observa-se um comportamento de diminuição de repulsão dos iões, pode ser atribuído à protonação dos grupos carboxílicos (-COOH), pelo que seu pKa está em 3,65 (Bratskaya, Schwarz e Chervonetsky, 2004) e não se apresenta outro comportamento de protonação evidente a partir de $\mathrm{pH} 5$, de certa forma, evidencia a presença dos grupos carboxílicos nas macromoléculas (Zhang e Bai, 2003).

Em contraste, os grânulos de quitosana têm potencial zeta positivo em soluções ácidas e negativos em soluções básicas, com um ponto isoelétrico no $\mathrm{pH} 6$, mostrando sua solubilidade em água no meio ácido por protonação do grupo amino $\left(-\mathrm{NH}_{2}\right.$ a $\left.\mathrm{NH}_{3}{ }^{+}\right)$a $\mathrm{pH}<6$, conforme relatado por (Rinaudo, 2006; Zhang e Bai, 2003), e estando perto de seu pKa em 6,3 e 6,7, de acordo com (Yan e Bai, 2005). Para valores crescentes de $\mathrm{pH}$ a partir de 7 é notada a sua neutralização debido à desprotonação e insolubilidade de dos grupos $-\mathrm{NH}_{2}{ }^{-}$para $-\mathrm{NH}^{-}$(Quemeneur, Rinaudo e Pépin-donat, 2008; Rinaudo, 2006; Zhang e Bai, 2003).

No caso do rejeito de $\mathrm{Ni}, \mathrm{o} \mathrm{pH}$ medido original da polpa apresentou-se na faixa de $6,5<\mathrm{pH}<7$, para os testes do potencial zeta foi preparado em duas concentrações de eletrólito $\left(0,001 \mathrm{M}\right.$ e $\left.0,01 \mathrm{M} \mathrm{KNO}_{3}\right)$, mostraram apresentar dois pontos isoelétricos, em $\mathrm{pH}=3$ e em $\mathrm{pH}=10,5$ e também se observa que o eletrolito é indiferente, e evidencia uma zona coloidal estável na fixa de $6,8<\mathrm{pH}<9$, aproximadamente. Acima do $\mathrm{pH}=10,5$, as partículas do rejeito de Ni mostram uma reversão de cargas para positivas e na faixa ácida (até $\mathrm{pH}=3$ ), as partículas apresentam cargas negativas, mais encontram-se na zona coloidal instável. A mesma situação acontece desde $0 \mathrm{pH}$ de 9 até $\mathrm{opH}$ de 12, as partículas apresentam cargas negativas mais estão como uma suspensão instávei. 


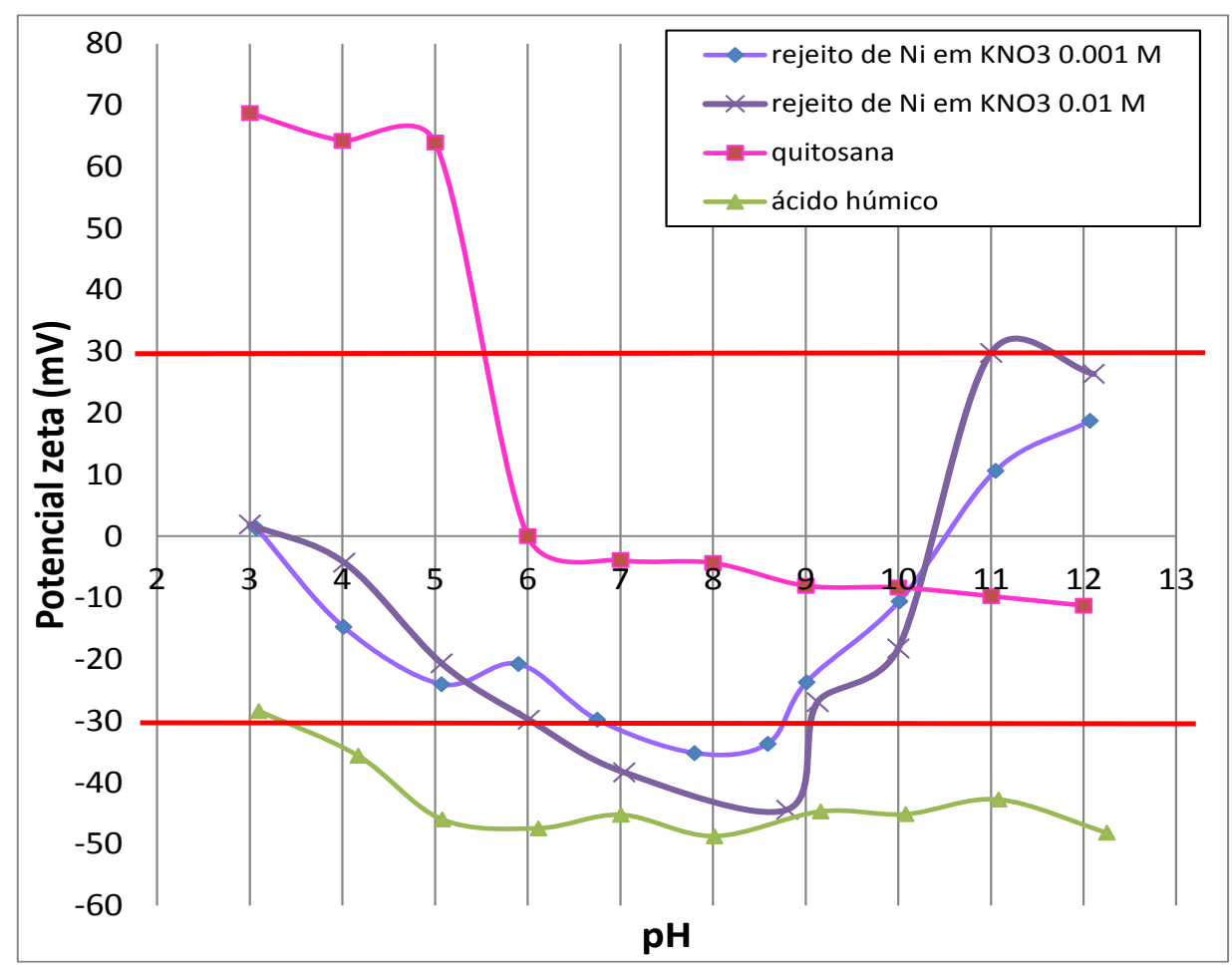

Figura 51 Potencial zeta do rejeito de Ni em granulometria menor a $20 \mu \mathrm{m}$

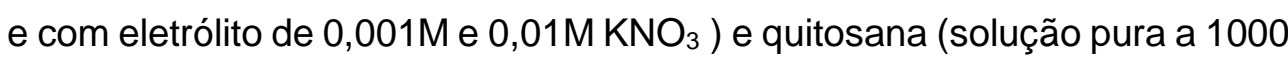
ppm) e do ácido húmico (solução pura a 100 ppm), em água Mili-Q.

\subsubsection{Determinação de tamanho de agregados (flocos) em função do $\mathrm{pH}$}

O monitoramento do tamanho dos agregados é uma forma de avaliar o grau de agregação de um sistema, já que se espera que na região do ponto isoelétrico o material esteja mais aglomerado, devido à ausência de cargas repulsivas na superfície. A medida foi realizada em equipamento Malvern Mastersizer 2000P, por meio da técnica de espalhamento de luz, sem ligar o ultrassom, para não descaracterizar o tamanho real dos agregados.

A Figura 52 apresenta os resultados do tamanho médio das partículas em função do $\mathrm{pH}$ para o rejeito de $\mathrm{Ni}$. Na região de $\mathrm{pH}$ próxima ao ponto isoelétrico (pH 3) o material apresenta maior tamanho de 'partícula', ou seja, provavelmente encontra-se aglomerado. O gráfico apresenta também que a região com partículas de maior tamanho encontra-se no $\mathrm{pH}=2$; o mesmo pode ser observado em $\mathrm{pH}=$ 12, e uma aglomeração leve de partículas estando perto do segundo ponto isoelétrico do rejeito de $\mathrm{Ni}$ a $\mathrm{pH}=10,5$ (Figura 51). Essa aproximação entre as partículas se deve, principalmente, à redução na dupla camada elétrica permitindo uma maior coesão entre elas. 


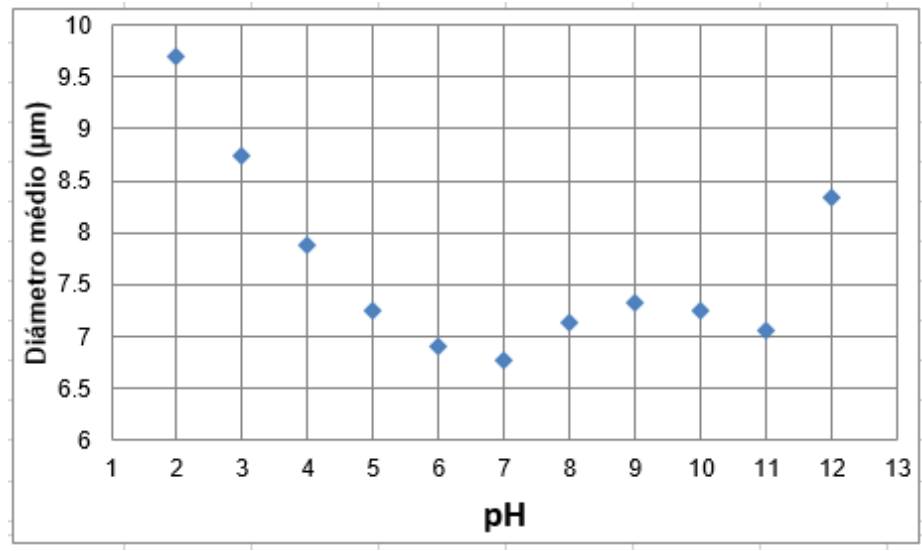

Figura 52 Agregação de partículas do rejeito de $\mathrm{Ni}(0.1 \%)$ em função do $\mathrm{pH}$, no Malvern Mastersizer 2000P, em água Mili-Q.

\subsubsection{Pre-testes de floculação}

Baseado nas análises de caracterização, interação eletrostática e aglomerados de tamanhos de partículas, se realizaram pre-testes de floculação para ajustar os parâmetros do planejamento experimental. A polpa inicalmente apresenta uma turbidez de 271 NTU, (Figura 53).

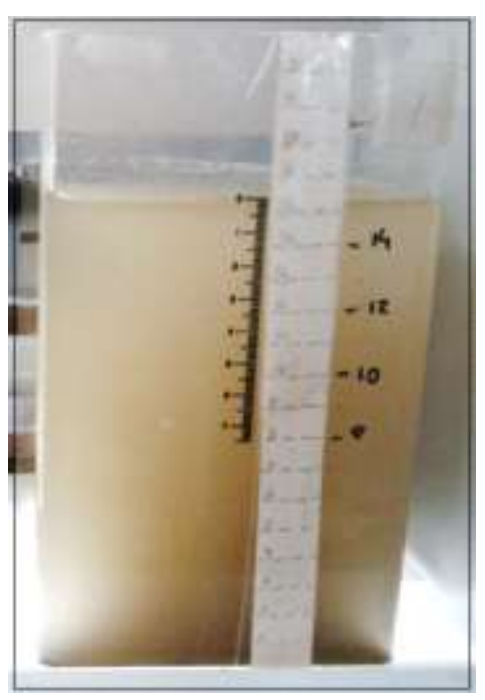

Figura 53 Turbidez da polpa do rejeito de Ni (0.5\%) sem flocular (271 NTU), em água torneira, com 225 rpm, no jar test.

\subsubsection{Efeito de relação Acido Humico/Quitosana (AH/Q)}

$\mathrm{Na}$ interação do ácido húmico com a quitosana $(\mathrm{AH} / \mathrm{Q})$, foram obtidos valores diferentes de $\mathrm{pH}$ na solução resultante (cada reagente apresenta um $\mathrm{pH}$ 
natural). Como se pode observar na Figura 54, tem dois pontos que refletam uma eficiente floculação de partículas, em pH de 6,75 com uma resposta de turbidez de 32 NTU, com $40 \%$ de ácido húmico presente e $60 \%$ de quitosana, e em pH de 8,08 com uma resposta de turbidez de 25 NTU, com $75 \%$ de ácido húmico e $25 \%$ de quitosana, o que faz refletir o comportamento dos pKa do ácido húmico, sobre a adsorção das partículas, referenciado por (Bratskaya, Schwarz e Chervonetsky, 2004).

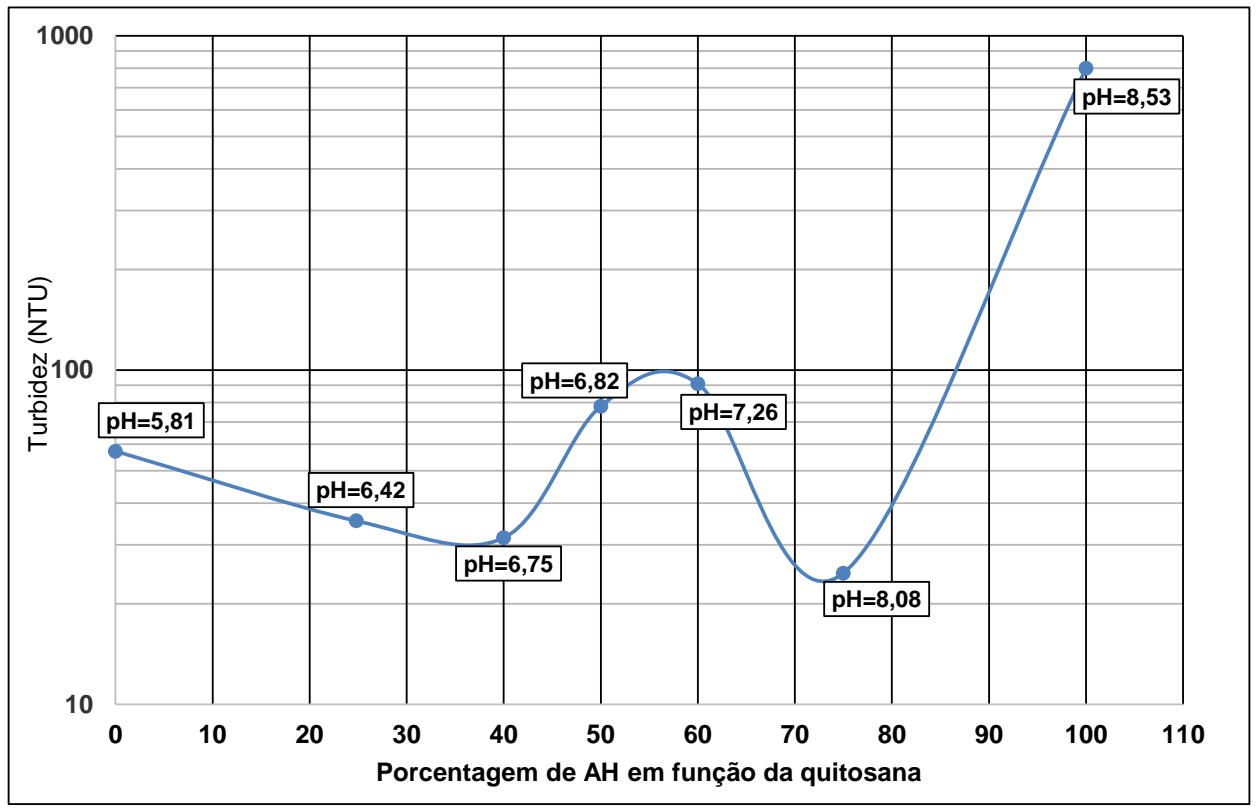

Figura 54 Adsorção em diferentes porcentagens de $A H / Q$ no rejeito de $\mathrm{Ni}$ $(0,5 \%)$, em 225 rpm, no jar test

\subsubsection{Efeito dos cátions da água na floculação}

Com o objetivo de analizar a influencia dos cátions $\mathrm{Ca}, \mathrm{Mg}, \mathrm{Na}$ e $\mathrm{K}$ na água da torneira sobre a desestabilização das cargas do rejeito de $\mathrm{Ni}$, foram realizados testes com água de torneira e com água Mili-Q. Pode-se observar na Figura 55, a forte influencia dos cátions na adsorção partículas-polímero, na faixa ácida a neutra do $\mathrm{pH}$, evidenciando que acima do $\mathrm{pH}$ 8, os grupos do ácido húmico já não estão ativos, e que o ácido húmico em presença da quitosana, tem uma influencia na adsorção das partículas em pH de 6,85 no caso da água da torneira e em pH de 7,32 no caso da água Mili-Q. 


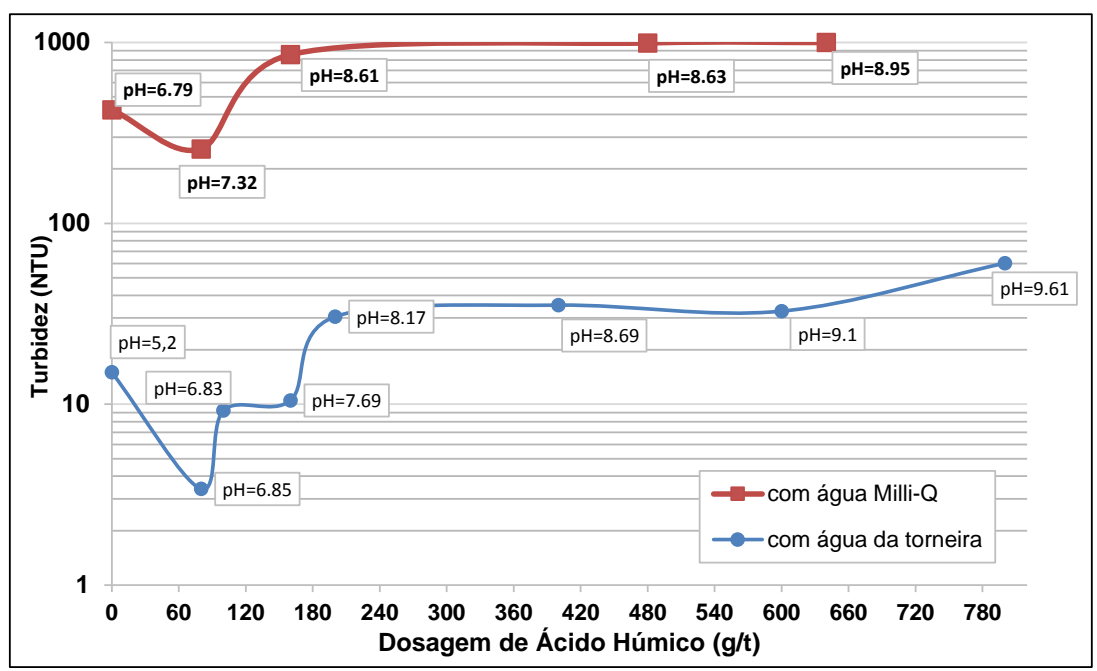

Figura 55 Adsorção da quitosana (680 g/t) na polpa do rejeito de $\mathrm{Ni}(0,25 \%$ de sólidos), em 225 rpm, no jar test.

\subsubsection{Efeito da quitosana e do ácido húmico a pH constante}

Com base nos resultados da Figura 54 e da Figura 55, verificou-se que para valores de $\mathrm{pH}$ em torno de 6,5 e 7,0 foram obtidas as melhores remoções de turbidez. Dessa forma foram realizados ajustes nas dossagens dos reagentes para polpas em $\mathrm{pH} 6,7$, para $0,5 \%$ de sólidos, como se pode observar na Figura 56, a influencia dos cátions presentes na água torneira é bem influenciable, na adsorção das partículas, e a floculação que obteve melhor resposta de turbidez foi de 13,8 NTU, em $100 \mathrm{~g} / \mathrm{t}$ de quitosana e de 5,6 g/t de ácido húmico.

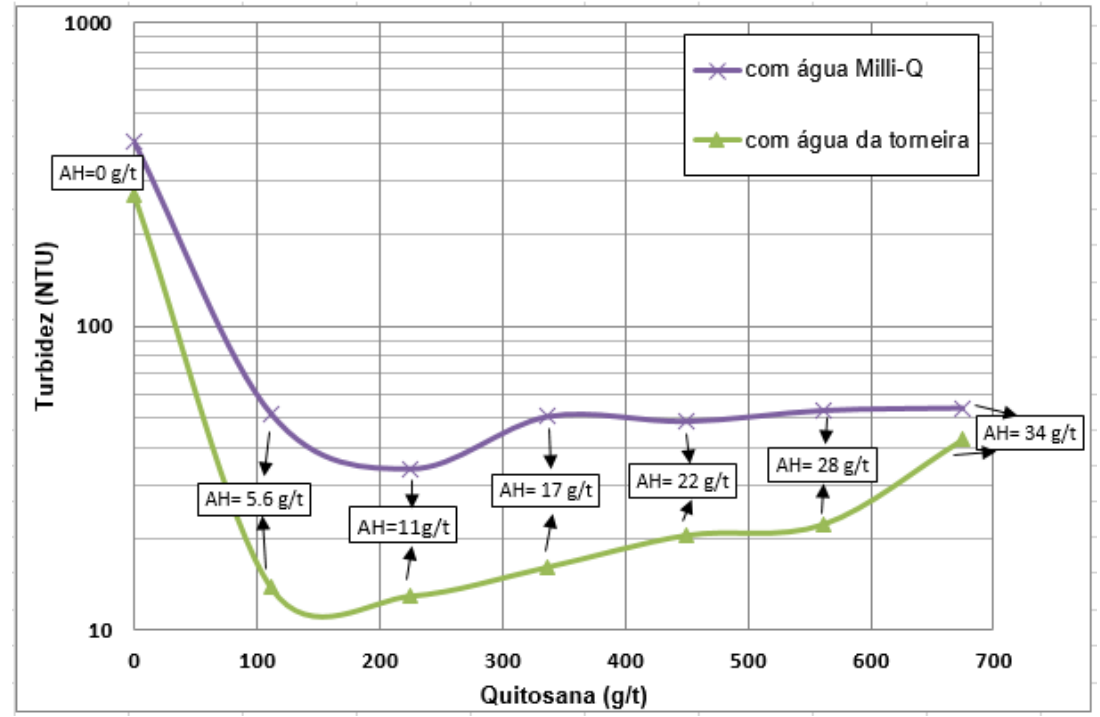

Figura 56 Adsorção da quitosana e do $\mathrm{AH}$, no rejeito de $\mathrm{Ni}$ (0,5\% de sólidos) em pH 6,7, em 225 rpm, no jar test. 


\subsubsection{Efeito de concentração de sólidos}

Para ajustar a quantidade de sólidos em função da capacidade de adsorção da quitosana e do ácido humico, foram avaliadas diferentes percentagens de sólidos (Figura 57). A capacidade de adsorção na presença de $680 \mathrm{~g} / \mathrm{t}$ de quitosana e de $80 \mathrm{~g} / \mathrm{t}$ de ácido húmico, esteve limitada até $1 \%$ de sólidos, para cumprir a regulação do CONAMA 357 (Silva, 2005), que exige ter uma meia de 40 NTU de turbidez.

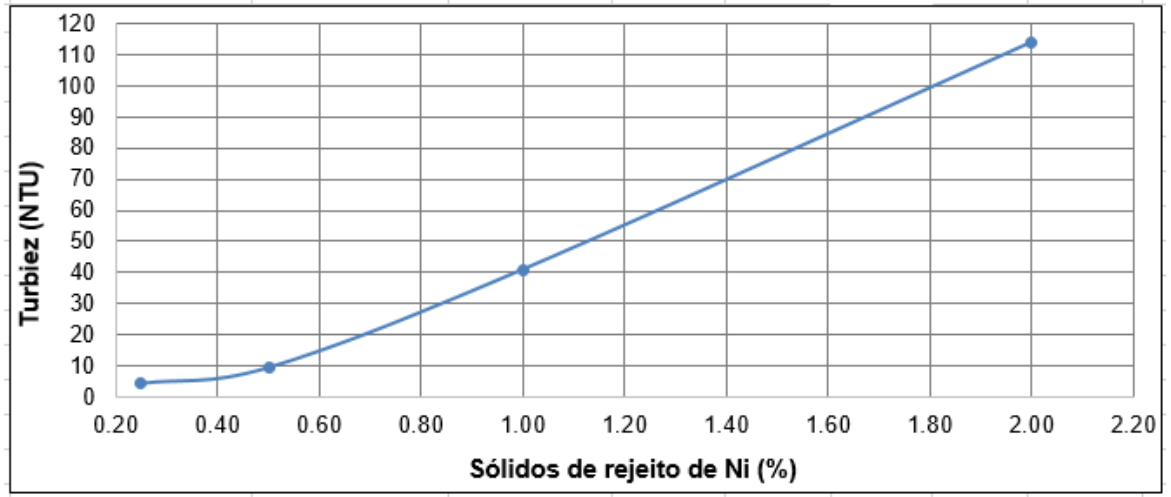

Figura 57 Adsorção da quitosana (680 g/t) e AH (80 g/t) nas partículas do rejeito de $\mathrm{Ni}$, em pH 7 e 225 rpm, no jar test. 


\subsubsection{Desenvolvimento do planejamento experimental para o rejeito de $\mathrm{Ni}$}

Os resultados da turbidez para cada teste do planejamento experimental do rejeito de Ni são apresentados na Tabela 12, com três pontos centrais.

Tabela 12 Planejamento experimental para o rejeito de $\mathrm{Ni}$, em $\mathrm{pH} 7$

\begin{tabular}{|c|c|c|c|c|c|c|}
\hline & $\begin{array}{l}\text { Conc. de } \\
\text { sólidos (\%) }\end{array}$ & $\begin{array}{c}\text { Quitosana } \\
(\mathrm{g} / \mathrm{t})\end{array}$ & $\begin{array}{l}\mathrm{AH} \\
(\mathrm{g} / \mathrm{t})\end{array}$ & $\begin{array}{c}\text { Velocidade de } \\
\text { agitação } \\
\text { (rpm) }\end{array}$ & $\begin{array}{c}\text { Tempo de } \\
\text { agitação (min) }\end{array}$ & $\begin{array}{c}\text { Turbidez } \\
\text { (NTU) }\end{array}$ \\
\hline Teste & $\mathbf{A}$ & $\bar{B}$ & C & D & $E$ & $\mathbf{Y}$ \\
\hline 1 & 1 & 20 & 1,5 & 175 & 1 & 40,4 \\
\hline 2 & 2 & 20 & 1,5 & 175 & 1 & 19,4 \\
\hline 3 & 1 & 100 & 1,5 & 175 & 1 & 19,0 \\
\hline 4 & 2 & 100 & 1,5 & 175 & 1 & 13,2 \\
\hline 5 & 1 & 20 & 5 & 175 & 1 & 67,9 \\
\hline 6 & 2 & 20 & 5 & 175 & 1 & 31,3 \\
\hline 7 & 1 & 100 & 5 & 175 & 1 & 24,0 \\
\hline 8 & 2 & 100 & 5 & 175 & 1 & 12,8 \\
\hline 9 & 1 & 20 & 1,5 & 275 & 1 & 100,3 \\
\hline 10 & 2 & 20 & 1,5 & 275 & 1 & 54,5 \\
\hline 11 & 1 & 100 & 1,5 & 275 & 1 & 43,7 \\
\hline 12 & 2 & 100 & 1,5 & 275 & 1 & 33,5 \\
\hline 13 & 1 & 20 & 5 & 275 & 1 & 83,9 \\
\hline 14 & 2 & 20 & 5 & 275 & 1 & 59,4 \\
\hline 15 & 1 & 100 & 5 & 275 & 1 & 41,4 \\
\hline 16 & 2 & 100 & 5 & 275 & 1 & 33,0 \\
\hline 17 & 1 & 20 & 1,5 & 175 & 3 & 71,1 \\
\hline 18 & 2 & 20 & 1,5 & 175 & 3 & 59,2 \\
\hline 19 & 1 & 100 & 1,5 & 175 & 3 & 29,3 \\
\hline 20 & 2 & 100 & 1,5 & 175 & 3 & 32,6 \\
\hline 21 & 1 & 20 & 5 & 175 & 3 & 66,9 \\
\hline 22 & 2 & 20 & 5 & 175 & 3 & 71,0 \\
\hline 23 & 1 & 100 & 5 & 175 & 3 & 34,6 \\
\hline 24 & 2 & 100 & 5 & 175 & 3 & 40,1 \\
\hline 25 & 1 & 20 & 1,5 & 275 & 3 & 93,2 \\
\hline 26 & 2 & 20 & 1,5 & 275 & 3 & 73,7 \\
\hline 27 & 1 & 100 & 1,5 & 275 & 3 & 53,7 \\
\hline 28 & 2 & 100 & 1,5 & 275 & 3 & 38,0 \\
\hline 29 & 1 & 20 & 5 & 275 & 3 & 73,9 \\
\hline 30 & 2 & 20 & 5 & 275 & 3 & 75,8 \\
\hline 31 & 1 & 100 & 5 & 275 & 3 & 50,0 \\
\hline 32 & 2 & 100 & 5 & 275 & 3 & 35,8 \\
\hline 33 & 1,5 & 60 & 3,25 & 225 & 2 & 61,2 \\
\hline 34 & 1,5 & 60 & 3,25 & 225 & 2 & 63,5 \\
\hline 35 & 1,5 & 60 & 3,25 & 225 & 2 & 64,5 \\
\hline
\end{tabular}




\subsubsection{Análise da variância com réplicas no ponto central}

a) Média dos testes (exceto pontos centrais):

$$
\bar{Y}=49,2 \text { NTU }
$$

b) Média dos pontos centrais:

$$
\bar{y}=63,07 \text { NTU }
$$

Para o cálculo dos efeitos de cada tratamento se multiplica a transposta da matriz codificada (Tabela 2), pela matriz das respostas da variável dependente (turbidez). E para o cálculo da soma de quadrados dos efeitos de cada tratamento, se utiliza a Equação (21), (Ayres, Torres e Ponce, 2000).

$$
S S_{x j}=\frac{\left[(X)^{T}(Y)\right]^{2}}{N}
$$

Os resultados são apresentados na Tabela 37 (ANEXO 4).

Baseado nos cálculos realizados na Tabela 38 (ANEXO 5), a análise da variância se apresenta na Tabela 13, para o rejeito de $\mathrm{Ni}$, que determina os efeitos independentes e interações significativas, segundo as tabelas de Fischer (Ayres,

\begin{tabular}{|c|c|c|c|c|}
\hline Efeito & SSxj & g.l & MSSxj & Fo \\
\hline $\bar{A}$ & 1379,4 & 1 & 1379,4 & 481,8 \\
\hline$B$ & 8048,6 & 1 & 8048,6 & 2810,9 \\
\hline C & 23,0 & 1 & 23,0 & 8,0 \\
\hline $\mathrm{D}$ & 3020,6 & 1 & 3020,6 & 1054,9 \\
\hline$E$ & 1527,7 & 1 & 1527,7 & 533,5 \\
\hline $\mathrm{AB}$ & 292,2 & 1 & 292,2 & 102,1 \\
\hline AC & 59,1 & 1 & 59,1 & 20,7 \\
\hline$\overline{A D}$ & 122,9 & 1 & 122,9 & 42,9 \\
\hline$\overline{A E}$ & 430,0 & 1 & 430,0 & 150,2 \\
\hline $\mathrm{BC}$ & 2,9 & 1 & 2,9 & 1,0 \\
\hline$\overline{B D}$ & 127,6 & 1 & 127,6 & 44,6 \\
\hline$\overline{\mathrm{BE}}$ & 36,8 & 1 & 36,8 & 12,8 \\
\hline CD & 323,2 & 1 & 323,2 & 112,9 \\
\hline CE & 32,6 & 1 & 32,6 & 11,4 \\
\hline$\overline{D E}$ & 548,6 & 1 & 548,6 & 191,6 \\
\hline Curvatura & 524,4 & 1 & 524,4 & 183,1 \\
\hline Erro & 5,7 & 2 & 2,9 & \\
\hline Total & 16505,3 & 18 & & \\
\hline
\end{tabular}
Torres e Ponce, 2000).

Tabela 13 Análise da variância. 
Uma variável ou interação é significativa se a seguinte relação é cumprida se:

$$
\text { Fo }>F(\alpha \text { gl,gle })
$$

A partir de tabelas de distribuição de Fisher, onde $\alpha=0,01, g l=1, g l e=2$, a um nível de significância do 99\%, o valor de $\mathrm{F}_{0.01}$ é 98.5 (Ver ANEXO 19). Porém, pode-se observar na Tabela 11 que as variáveis significativas são: A (concentração de sólidos), B (dosagem de quitosana), D (velocidade de agitação), e as interações: $A B$ (concentração de sólidos-quitosana), AD (concentração de sólidos-velocidade de agitação), AE (concentração de sólidos-tempo de agitação), $\mathrm{BD}$ (quitosana-velocidade de agitação), BE (quitosana-tempo de agitação), CE (ácido húmico-tempo de agitação) e DE (velocidade de agitação-tempo de agitação), além disso, foi observado um efeito de curvatura, portanto o modelo linear não se ajusta aos parâmetros das variáveis estabelecidas nos testes. Dessa forma, a otimização do modelo foi realizada considerando-se um modelo de segunda ordem, utilizando o planejamento composto central.

\subsubsection{Planejamento composto central}

Como já foi mencionado no item 4.2.8.2, para desenvolver o desenho composto central requer-se novos valores para os testes do desenho composto central, fora dos pontos da faixa de parâmetros estabelecidos no planejamento experimental inicial $\left(2^{k}\right)$. A Tabela 39 (ANEXO 6) apresenta a matriz codificada para o novo requerimento de testes, para obtenção do modelo de segundo ordem.

Em função dos cálculos desenvolvidos para cada parâmetro do fator ou variável estabelecida, se desenvolveu os testes do desenho composto central, como é apresentado na Tabela 14. Como se pode observar no teste 7, para uma concentração de sólidos de 1,5\%, se obteve uma turbidez de 13,4 NTU, utilizando as mesmas dosagens de quitosana e do $\mathrm{AH}$ e para o mesmo tempo de agitação utilizados para o teste 1 , que gerou uma turbidez de 3,4 NTU, com $0,31 \%$ de concentração de sólidos, quase 5 vezes menor do que o teste 7 . É importante frisar que a única diferença entre esses testes foi a velocidade de agitação, que foi pela velocidade de agitação de $106 \mathrm{rpm}$ para o teste 7 e de $225 \mathrm{rpm}$ para o teste 1 , evidenciando uma possível quebra dos flocos. 
Tabela 14 Desenho composto central para o rejeito de $\mathrm{Ni}$.

\begin{tabular}{|c|c|c|c|c|c|c|}
\hline Teste & $\begin{array}{l}\text { Conc. } \\
\text { sólidos } \\
(\%)\end{array}$ & $\begin{array}{c}\text { quitosana } \\
(g / t)\end{array}$ & $\begin{array}{l}\mathrm{AH} \\
(\mathrm{g} / \mathrm{t})\end{array}$ & $\begin{array}{l}\text { Veloc. } \\
\text { agitação } \\
\text { (rpm) }\end{array}$ & $\begin{array}{l}\text { Tempo } \\
\text { agitação } \\
\text { (min.) }\end{array}$ & $\begin{array}{c}\text { Turbidez } \\
\text { (NTU) }\end{array}$ \\
\hline 1 & 0,31 & 60 & 3,25 & 225 & 2 & 3,39 \\
\hline 2 & 2,69 & 60 & 3,25 & 225 & 2 & 67,55 \\
\hline 3 & 1,5 & 35,14 & 3,25 & 225 & 2 & 64,1 \\
\hline 4 & 1,5 & 155,14 & 3,25 & 225 & 2 & 38,85 \\
\hline 5 & 1,5 & 60 & 0,87 & 225 & 2 & 63,35 \\
\hline 6 & 1,5 & 60 & 9,16 & 225 & 2 & 58,45 \\
\hline 7 & 1,5 & 60 & 3,25 & 106,1 & 2 & 13,4 \\
\hline 8 & 1,5 & 60 & 3,25 & 343,9 & 2 & 71 \\
\hline 9 & 1,5 & 60 & 3,25 & 225 & 0,4 & 47,3 \\
\hline 10 & 1,5 & 60 & 3,25 & 225 & 4,4 & 67,65 \\
\hline
\end{tabular}

Utilizando o programa estatístico"STATGRAPHICS CENTURION 16.0", foram realizadas as seguintes análises estatísticas:

> Na Tabela 15, se desenvolveu a análise de variância do desenho composto central, com um nível de significância do $95 \%$, onde se pode observar que a quitosana, a velocidade de agitação, e o tempo de agitação como variáveis independentes foram significativas. As interações significativas foram: $A^{2}, D^{2}$, CD e ED. O coeficiente de correlação do modelo foi de $93,4 \%$, indicando que o modelo se ajusta a um modelo de segunda ordem, como se pode observar na Tabela 16. 
Tabela 15 Análise de variância do desenho composto central.

\begin{tabular}{|c|c|c|c|c|}
\hline \multirow[b]{2}{*}{ FATOR } & \multirow[b]{2}{*}{ Estimação } & \multirow{2}{*}{$\begin{array}{l}\text { Erro } \\
\text { Padrão }\end{array}$} & \multicolumn{2}{|c|}{ Estatístico } \\
\hline & & & $\mathbf{T}$ & Valor-P \\
\hline CONSTANTE & 61,40 & 3,84 & 15,99 & 0,000 \\
\hline A: Conc. sólidos & 6,87 & 4,87 & 1,41 & 0,172 \\
\hline B: quitosana & $-14,86$ & 1,40 & $-10,61$ & 0,000 \\
\hline C: AH & 0,48 & 1,13 & 0,43 & 0,675 \\
\hline D: veloc. agitação & 9,80 & 1,06 & 9,28 & 0,000 \\
\hline E: tempo agitação & 6,43 & 1,02 & 6,31 & 0,000 \\
\hline$A^{\star} A$ : Conc. sólidos ${ }^{\star}$ Conc. sólidos & $-5,66$ & 1,12 & $-5,04$ & 0,000 \\
\hline $\mathrm{B}^{\star} \mathrm{B}$ : quitosana ${ }^{\star}$ quitosana & $-1,50$ & 1,13 & $-1,32$ & 0,198 \\
\hline $\mathrm{C}^{\star} \mathrm{C}: \mathrm{AH}{ }^{\star} \mathrm{AH}$ & $-0,04$ & 1,10 & $-0,04$ & 0,971 \\
\hline $\begin{array}{l}\text { D*D: veloc. agitação *veloc. } \\
\text { agitação }\end{array}$ & $-3,80$ & 1,09 & $-3,48$ & 0,002 \\
\hline 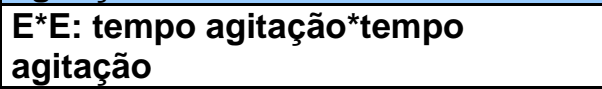 & $-0,95$ & 1,16 & $-0,82$ & 0,421 \\
\hline $\mathrm{A}^{\star} \mathrm{B}$ : Conc. sólidos ${ }^{\star}$ quitosana & 1,95 & 1,62 & 1,20 & 0,241 \\
\hline$A^{\star} C$ : Conc. sólidos ${ }^{\star} A H$ & $-0,74$ & 2,87 & $-0,26$ & 0,798 \\
\hline A*D: Conc. sólidos*veloc. agitação & $-7,48$ & 4,41 & $-1,70$ & 0,103 \\
\hline AE: Conc. sólidos`tempo agitação & $-9,01$ & 7,05 & $-1,28$ & 0,214 \\
\hline $\mathrm{B}^{\star} \mathrm{C}$ : quitosana*AH & $-0,32$ & 1,44 & $-0,22$ & 0,828 \\
\hline B*D: quitosana*veloc. agitação & $-2,05$ & 1,44 & $-1,42$ & 0,169 \\
\hline B`E: quitosana*tempo agitação & $-1,18$ & 1,44 & $-0,82$ & 0,423 \\
\hline $\mathrm{C}^{\star} \mathrm{D}:$ : AH*veloc. agitação & $-2,84$ & 1,18 & $-2,41$ & 0,025 \\
\hline $\mathrm{C}^{\star} \mathrm{E}: \mathrm{AH}{ }^{\star}$ tempo agitação & $-0,83$ & 1,18 & $-0,70$ & 0,488 \\
\hline $\begin{array}{l}\text { E*D: veloc. agitação*tempo } \\
\text { agitação }\end{array}$ & $-3,68$ & 1,09 & $-3,36$ & 0,003 \\
\hline
\end{tabular}

Tabela 16 Coeficiente de correlação do modelo de segundo ordem.

\begin{tabular}{|l|c|}
\hline R-quadrada = & $93,46 \%$ \\
\hline R-quadrado (ajustado para g.I.) $=$ & $87,78 \%$ \\
\hline Erro padrão do estimado = & 10,90 \\
\hline Erro absoluto médio = & 5,81 \\
\hline Estatístico Durbin-Watson = & 1,74 \\
\hline
\end{tabular}

\subsubsection{Obtenção do modelo matemático para o rejeito de $\mathrm{Ni}$}

Com base nos resultados da ánalise de variança do desenho de composto central, se determinou as variáveis significativas do processo de floculação, neste caso foram 7 os efeitos que apresentaram um valor $P$-value menor a 0,05 , indicando que são significativos com um nível de confiança do 95\%. 
O modelo matemático obtido é apresentado pela Equação (22):

Turbidez $=61,4-14,9 B+9,8 D+6,4 E-5,7 A^{2}-3,8 D^{2}-2,8 C D-3,7 D E$ (22)

\subsubsection{Decodificação do modelo matemático para o rejeito de Ni}

Para a decodificação do modelo, na Tabela 40 se determinou o raio e o centro do desenho (ANEXO 7).

Determinou-se, ainda, o termo independente e os termos lineares, mediante as equações apresentadas na Tabela 5.

O modelo decodificado é representado, então, pela Equação (23):

Turbidez $=38,6-0,4 B+1,1 D+23,1 E+22,8 A^{2}-0,013 D^{2}-0,032 C D-0,4 D E$ (23)

\subsubsection{Diagrama de Pareto}

O princípio do diagrama de Pareto, apresenta uma comparação quantitativa e fatores ordenados de acordo com a sua contribuição para um efeito particular, neste caso a turbidez. Porém na Figura 58, pode-se observar a maior influência das seguintes variáveis sobre a turbidez: a dosagem de quitosana, apresenta um efeito negativo para diminuir a turbidez, a velocidade de agitação e tempo de agitação, apresentam um efeito positivo, para o aumento da turbidez e as interações quadráticas da concentração de sólidos e da velocidade de agitação, e as interações de velocidade de agitação com tempo de agitação e do ácido húmico com velocidade de agitação, apresentam um efeito negativo, indicando a necessidade da diminuição do efeito conjunto de seus fatores para diminuir o resultado da turbidez. Nesses casos, deve-se utilizar a combinação de seus níveis baixos. 


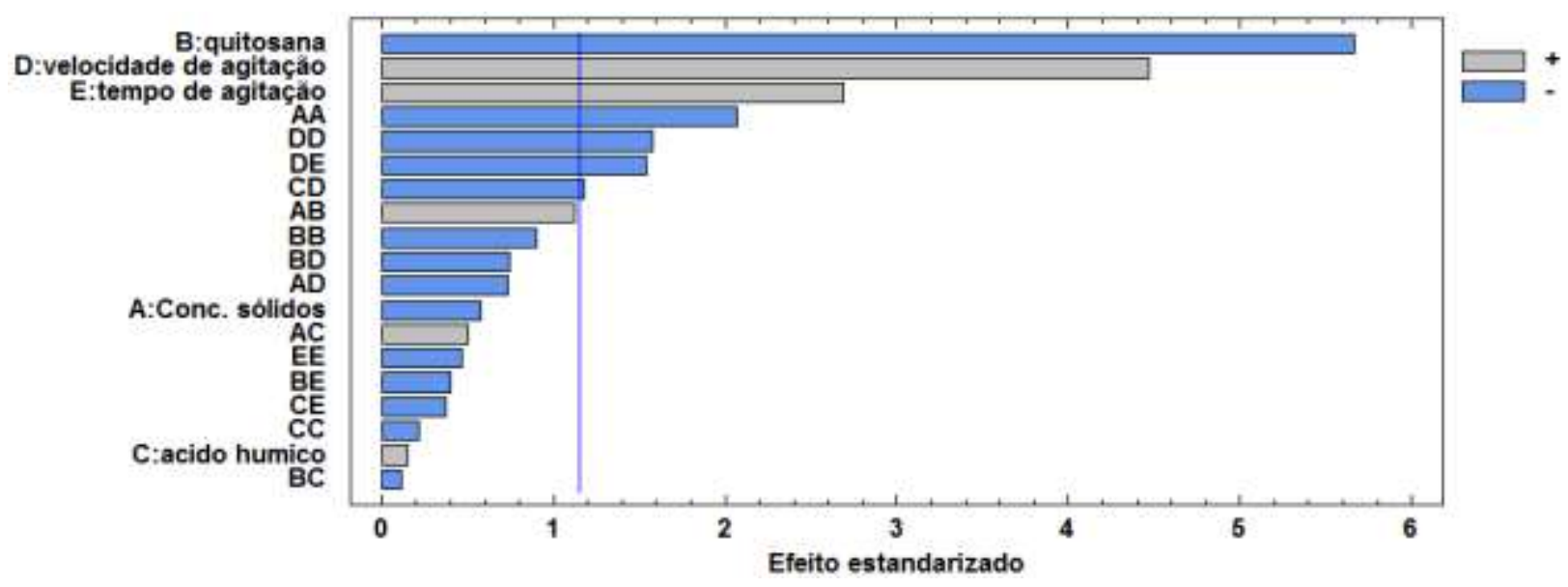

Figura 58 Diagrama de Pareto a pH 7

\subsubsection{Efeitos principais da turbidez}

Na Figura 59, apresentam-se os efeitos principais da turbidez, com relação à concentração de sólidos e do ácido húmico, nota-se uma parábola, indicando que a turbidez gerada pela variação dessas variáveis é quase constante, tanto no nível baixo quanto no nível alto do planejamento. Para a quitosana, tem-se uma inclinação negativa, o que demonstra uma relação inversamente proporcional com a turbidez, ou seja, quanto maior a quantidade de quitosana adicionada, menor será a turbidez residual do sobrenadante, como é confirmado com o modelo matemático, o sinal negativo $A$ velocidade e o tempo de agitação apresentam uma inclinação positiva, indicando que eles têm uma relação diretamente proporcional à turbidez; quanto maior o parâmetro da velocidade e o tempo de agitação, maior será o valor da turbidez residual, como é confirmado com o modelo matemático, o sinal positivo

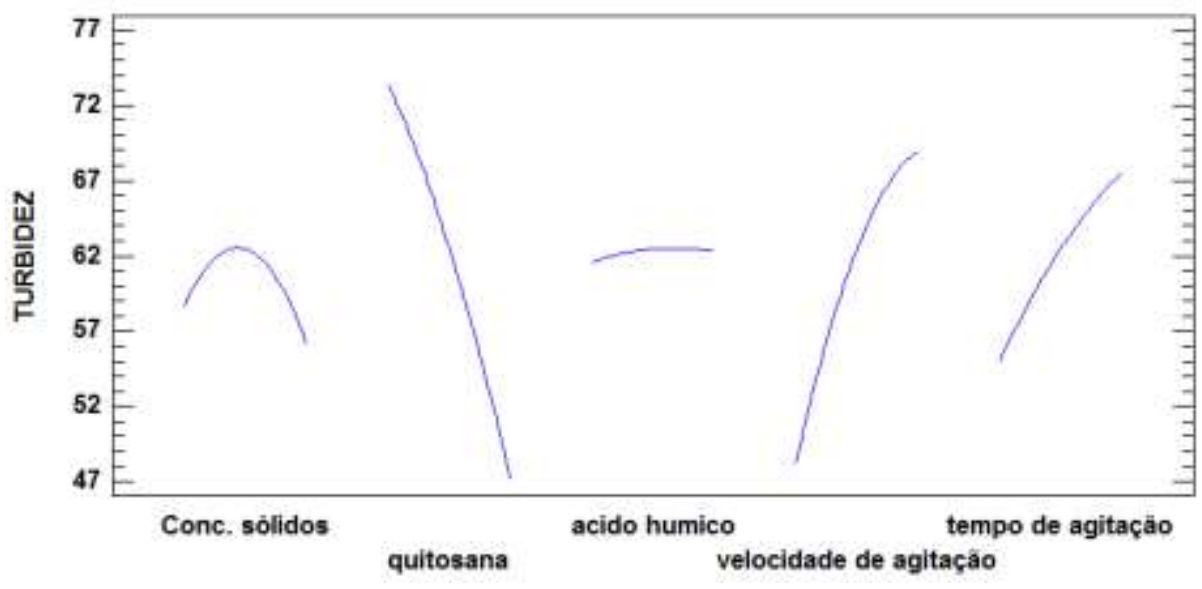

Figura 59 Gráfica dos efeitos principais das variáveis sobre a turbidez 


\subsubsection{Diagramas de superfície}

Os diagramas de superfície vão facilitar a visualização da descrição do comportamento das interações de 3 variáveis, mantendo duas variáveis fixas (valor central). Na Figura 60, mantendo a velocidade e o tempo de agitação no nível meio, apresenta que para obter $35 \mathrm{NTU}$, é favorecida em baixas dossagens de quitosana, alto nível de concentração de sólidos, e o efeito do ácido húmico não se apresenta significativo na redução da turbidez.

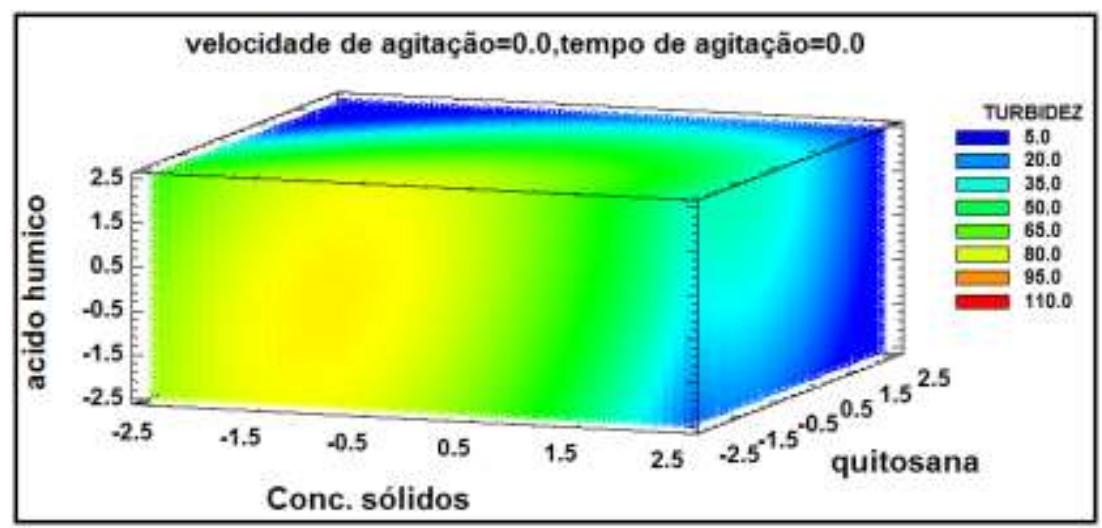

Figura 60 Diagrama de superfície AH-Conc. Sólidos-Quitosana

$\mathrm{Na}$ Figura 61, mantendo o $\mathrm{AH}$ e o tempo de agitação no nível meio, apresenta que para obter 35 NTU, em nível alto de concentração de sólidos em nível alto, a velocidade de agitação não deve ser maior do que o nível -1,5 (150 rpm) aproximadamente, a maior velocidade de agitação evidencia uma quebra de flocos, e com baixas dosagens de quitosana.

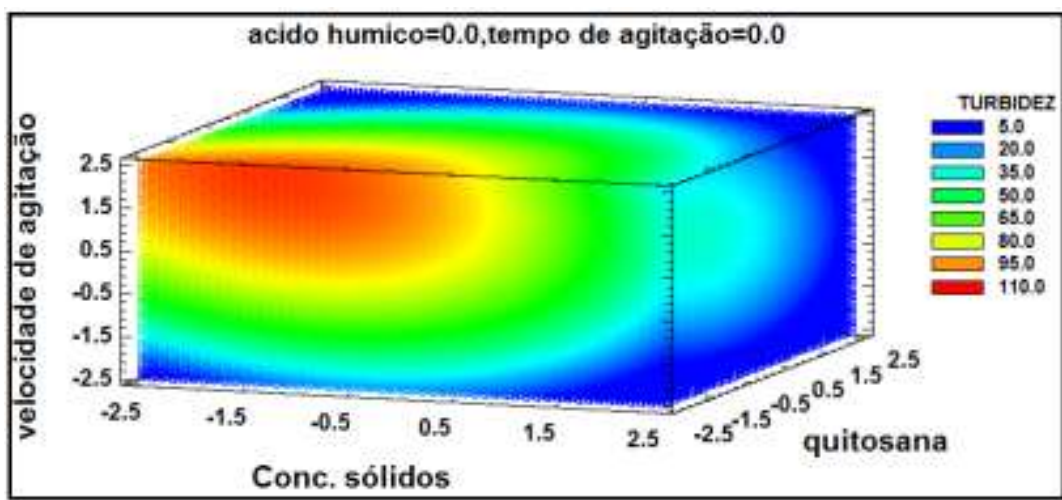

Figura 61 Diagrama de superfície Veloc. de agitação-Conc de sólidosQuitosana 
Na Figura 62, mantendo o $\mathrm{AH}$ e a velocidade de agitação no nível meio, apresenta que para obter 35 NTU, em o nível alto de concentração de sólidos, o tempo de agitação deve-se manter em nível meio, e com baixo nível de dosagem de quitosana.

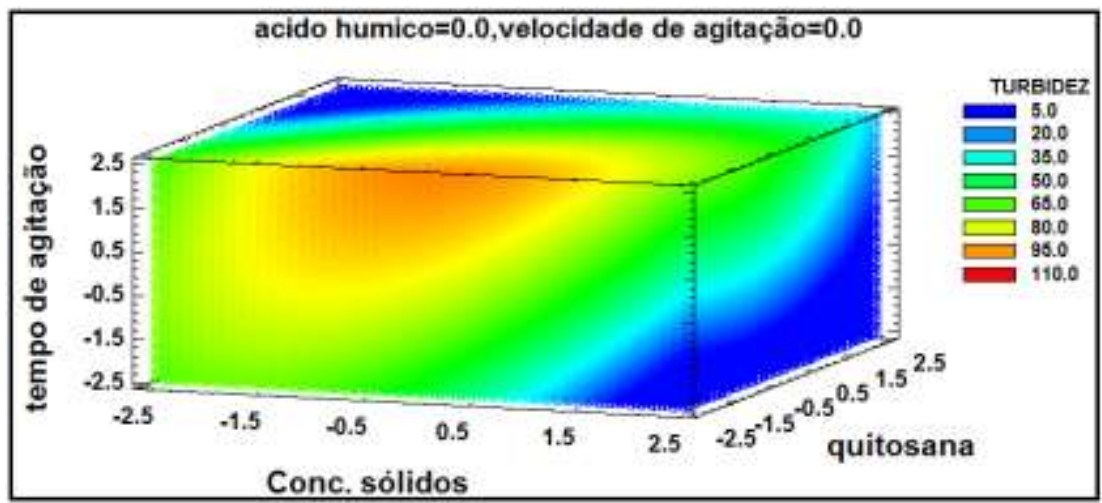

Figura 62 Diagrama de superfície Tempo de agitação-Conc de sólidosQuitosana

Na Figura 63, mantendo a quitosana e o tempo de agitação no nível meio, apresenta que para obter 35 NTU, em nível alto de concentração de sólidos, o ácido húmico deve-se manter em níveis baixos, com uma velocidade de agitação do nível $-1,5$ (150 rpm).

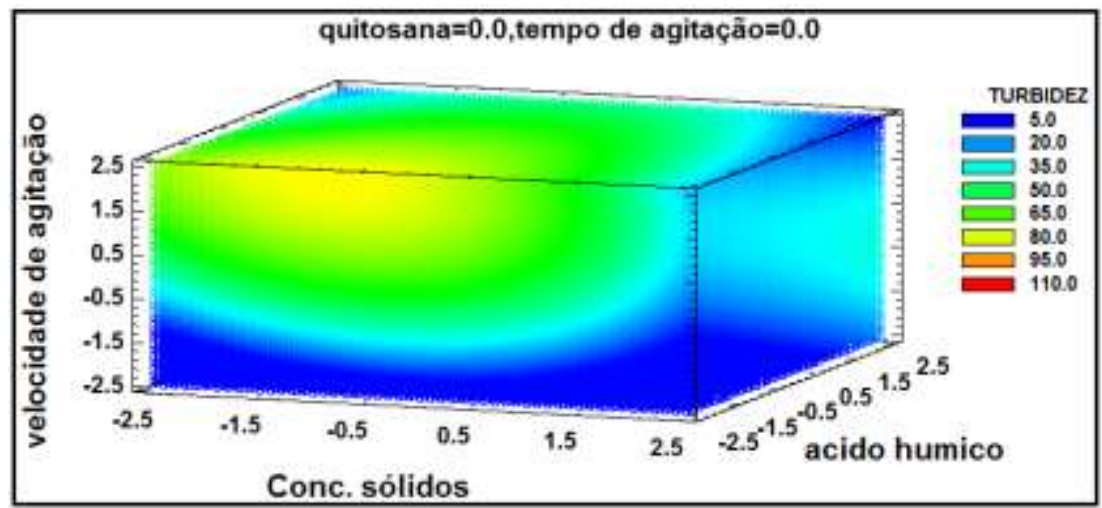

Figura 63 Diagrama de superfície Velocidade de agitação-Conc de sólidos$\mathrm{AH}$

$\mathrm{Na}$ Figura 64, mantendo a quitosana e a velocidade de agitação no nível meio, apresenta que para obter 35 NTU, em nível alto de concentração de sólidos, o ácido húmico quase não afeta na resposta de turbidez, e com tempo de agitação (menor a $2 \mathrm{~min}$ ) aproximadamente. 


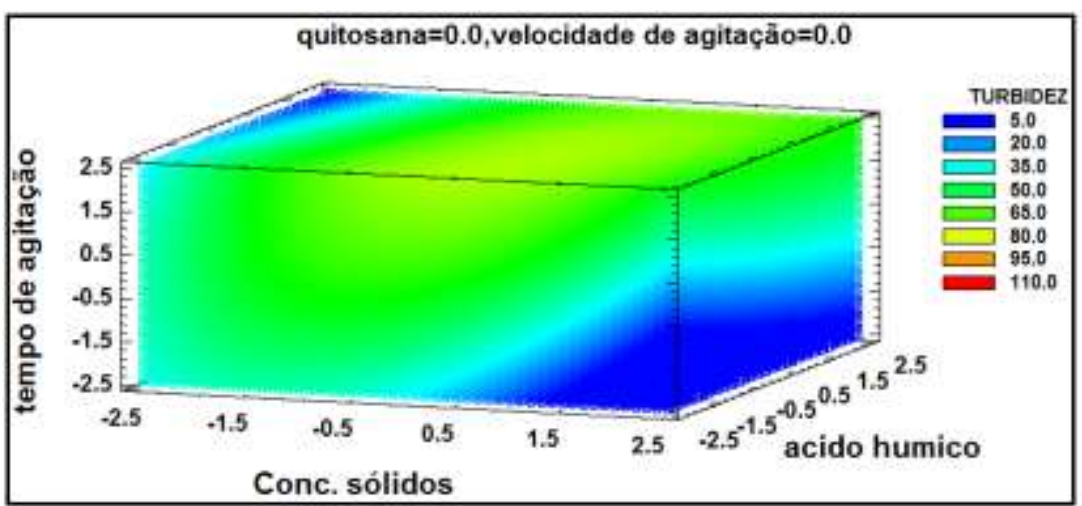

Figura 64 Diagrama de superfície Tempo de agitação-Conc de sólidos-AH

\subsubsection{Otimização de parâmetros}

Baseado no desenho composto central e com o uso do software estatístico Statgraphics Centurion 16.0, foi feita a minimização da turbidez para 35 NTU, dando a Tabela 41 (ANEXO 8).

Para a decodificação dos parâmetros foi utilizada a Equação (23), e os valores dos parâmetros ótimos calculados para uma turbidez de 35 NTU são apresentados na Tabela 17:

Tabela 17 Parâmetros otimizados do rejeito de Ni para uma turbidez de 35 NTU.

\begin{tabular}{|l|c|}
\hline Variável & Parâmetro \\
\hline Concent. Sólidos & $2,15 \%$ \\
\hline Dosagem quitosana & $24,9 \mathrm{~g} / \mathrm{t}$ \\
\hline Dosagem AH & $6,3 \mathrm{~g} / \mathrm{t}$ \\
\hline Velocidade de agitação rápida & $119 \mathrm{rpm}$ \\
\hline Tempo de agitação rápido & $1 \mathrm{~min} 41 \mathrm{~s}$. \\
\hline
\end{tabular}

Este ajuste do modelo de segunda ordem, realizado em $\mathrm{pH} 7$, faz refletir que se maximizou a concentração de sólidos, para um pouco mais acima do nível alto, se minimizou a dosagem da quitosana, perto do nível baixo, a dosagem de $\mathrm{AH}$ se maximizou pelo alto conteúdo de sólidos, a velocidade de agitação minimizou-se por embaixo do nível baixo (-1), original do planejamento experimental e o tempo de agitação manteve-se perto do nível central. 


\subsubsection{Testes de floculação com os parâmetros otimizados em função do pH}

Baseado nos parâmetros de otimização do rejeito de $\mathrm{Ni}$, foram realizados testes comparativos, para analisar a eficiência de floculação em diferentes valores de $\mathrm{pH}$ (3 a 9) e avaliar o comportamento de desestabilização das partículas. Nesses testes foi também avaliada a influência dos cátions presentes na água da torneira (geração de pontes partículas-polímeros). Os resultados desses testes foram comparados com os obtidos utilizando água Mili-Q (isenta de íons), para avaliação dos seguintes efeitos, floculação com quitosana, floculação com quitosana e ácido húmico.

\subsubsection{Efeito de floculação com quitosana}

Na Figura 65, desenvolveram-se dois tipos de floculação, com 2,15\% de sólidos, em presença de $24,9 \mathrm{~g} / \mathrm{t}$ de quitosana, em água de torneira e em água Mili-Q. O objetivo foi avaliar a presença da quitosana com os íons presentes na água da torneira. Em pH de 3 a 5 se obteve um comportamento semelhante, tanto para a floculação com água da torneira quanto com água Mili-Q, com respostas de turbidez bem parecidas. Na faixa de $\mathrm{pH}$ de 6 a 8 a resposta de turbidez na floculação com água torneira apresentou valor médio de 27 NTU e da floculação com água Mili-Q, de 34 NTU; porém, a presença de cátions na água da torneira foi relevante na faixa de $\mathrm{pH}$ neutra para a adsorção do polímero nas partículas.

A partir do $\mathrm{pH}$ de 9, a quitosana encontra-se desprotonada, portanto a sua capacidade de adsorção diminuiu, produzindo uma turbidez de 42 NTU, para o caso da floculação em água Mili-Q. No caso da floculação com água da torneira, o aumento da turbidez (82 NTU) pode ter sido ocasionado devido a uma reversão de cargas com os íons presentes, que promoveu o incremento da dupla camada elétrica (estabilização por esgotamento), interferindo na adsorção do polímero. Outra possibilidade é ter ocorrido o efeito de estabilização estérica, sem permitir a floculação. 


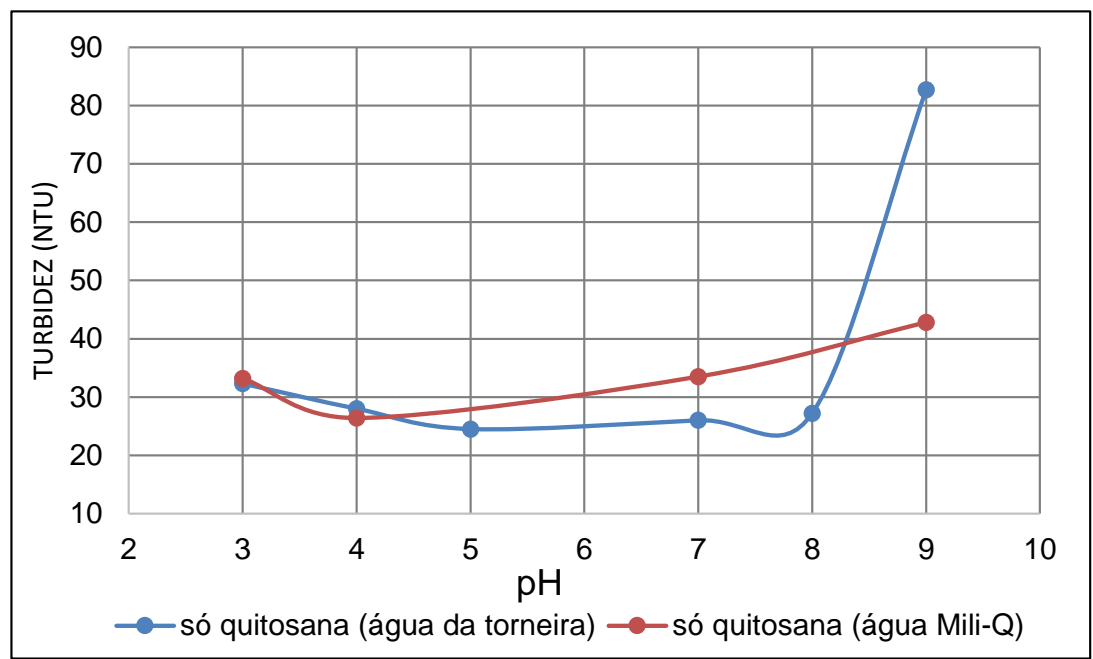

Figura 65 Floculação com 2,15\% de sólidos de rejeito de $\mathrm{Ni}$, com quitosana $(24,9 \mathrm{~g} / \mathrm{t})$, em água torneira e em água mili-Q, em 119 rpm, no jar test.

\subsubsection{Efeito de floculação da quitosana com AH}

Na Figura 66, desenvolveram-se dois tipos de floculação, com 2,15\% de sólidos, em água da torneira, em presença de 24,9 g/t de quitosana e 6,3 g/t de $\mathrm{AH}$ e so com $24,9 \mathrm{~g} / \mathrm{t}$ de quitosana. O objetivo foi avaliar a influencia da quitosana com e sem presença do $\mathrm{AH}$. Em pH de 3 e 4 pode-se observar uma maior diminuição da turbidez (20 NTU), na presença do AH e da quitosana do que na presença só da quitosana (30 NTU), o que faz refletir a interação dos grupos carboxílicos do $\mathrm{AH}$ com os grupos amino da quitosana, resultando um composto de caráter iónico bipolar e gerando uma maior adsorção das partículas. No pH 5 e 6 tiveram igual comportamento de adsorção dando uma turbidez de 25 NTU, tanto da quitosana com o $\mathrm{AH}$, como só da quitosana. Em pH de 7, 8 e 9 se observa que não houve interação dos grupos carboxílicos do $\mathrm{AH}$ com os grupos amino da quitosana, diferentemente do que foi observado na faixa ácida. Isso se deve, provavelmente, ao fato dos polímeros apresentarem estabilização estérica e não conseguirem se adsorver nas partículas, gerando sobrenadantes com turbidez de 33, 70 e 118 NTU, respectivamente.

Para os ensaios de floculação utilizando apenas a quitosana, nota-se que em pH 7 obteve-se uma turbidez de 27 NTU; em pH 8, alguns grupos da quitosana ainda estão protonados e conseguem adsorver-se nas partículas na presença dos ions da água produzindo turbidez de 28 NTU. Entretanto, a partir do $\mathrm{pH} 9$, a quitosana apresenta ma notável desprotonação de cargas e o possível efeito da estabilização estérica ou de uma estabilização por esgotamento devido à forte 
repulsão de cargas. Daí a observar-se uma turbidez bem mais elevada, de 82 NTU.

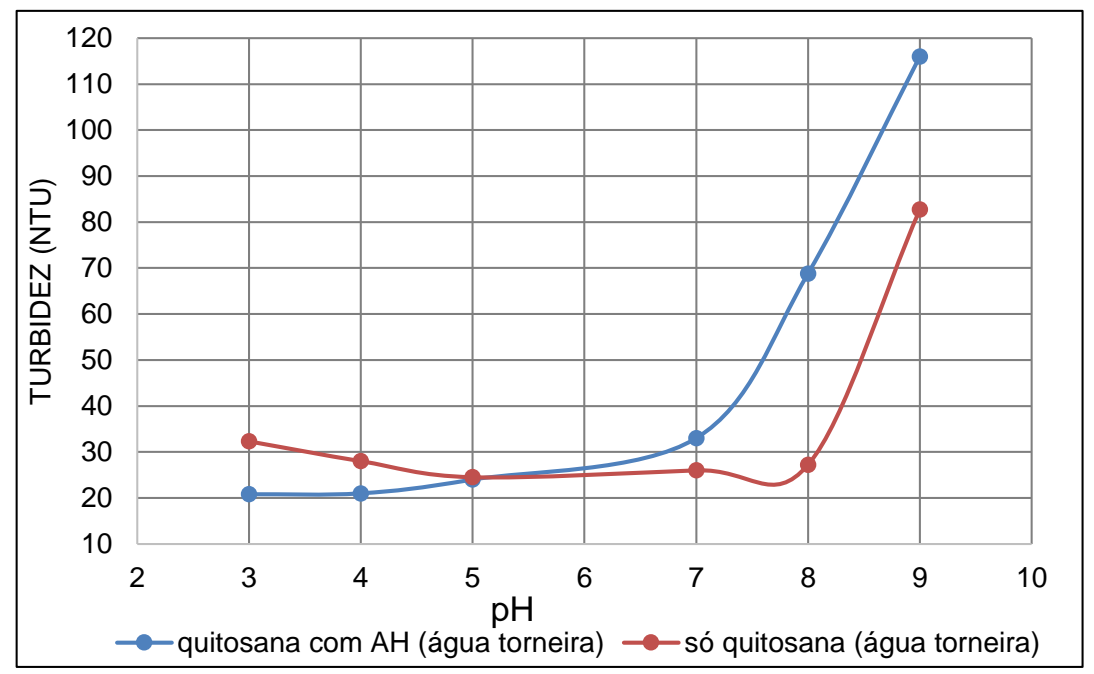

Figura 66 Floculação com 2,15\% de sólidos do rejeito de Ni, quitosana (24,9 $\mathrm{g} / \mathrm{t})$ e $\mathrm{AH}(6,3 \mathrm{~g} / \mathrm{t})$ e só com quitosana (24,9 g/t) em água torneira, a $119 \mathrm{rpm}$, no jar test.

\subsubsection{Efeito de floculação com quitosana e AH em água de torneira e água Mili-Q}

Na Figura 67, desenvolveram-se dois tipos de floculação: as polpas foram preparadas na concentração de $2,15 \%$ de sólidos, em água da torneira e em água Mili-Q, separadamente, na presença de $24,9 \mathrm{~g} / \mathrm{t}$ de quitosana e $6,3 \mathrm{~g} / \mathrm{t}$ de $\mathrm{AH}$. O objetivo desses ensaios foi avaliar a influência dos cátions presentes na água da torneira na presença dos dois polímeros. Na faixa ácida a neutra ( $\mathrm{pH}$ de 4 a 7), mostra-se um comportamento notável dos ions da água da torneira gerando pontes de ligação na adsorção das partículas em presença dos dois polímeros, quitosana e $\mathrm{AH}$, que foi observado pela resposta de turbidez menor do que na adsorção das partículas em água Mili-Q. Na presença dos dois polímeros, a partir do $\mathrm{pH} 8$ pode-se observar que a presença dos íons na água da torneira provavelmente promove uma reversão de cargas, gerando maior valor de turbidez (70 NTU). Para a floculação com água Mili-Q, a turbidez obtida foi de 43 NTU, certamente porque a ausência de íons promoveu a estabilização por esgotamento (aumento da dupla camada), e consequentemente a deficiente interação da quitosana e do $\mathrm{AH}$ com as partículas. 


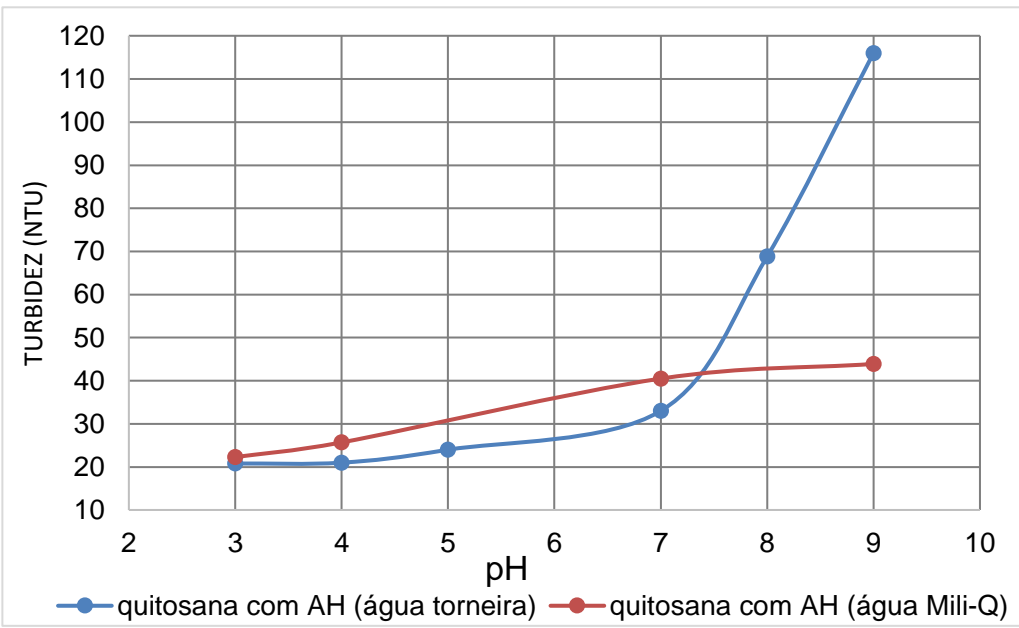

Figura 67 Floculação com 2,15\% de sólidos do rejeito de $\mathrm{Ni}$, quitosana $(24,9$ $\mathrm{g} / \mathrm{t})$ e $\mathrm{AH}(6,3 \mathrm{~g} / \mathrm{t})$, em água torneira e água Mili-Q respectivamente, em 119 rpm, no jar test.

\subsubsection{Efeito de floculação com quitosana e AH em água de torneira, com quitosana e AH em água mili-Q e só da quitosana em água Mili-Q}

Na Figura 68, desenvolveram-se três tipos de floculação, para polpas com 2,15\% de sólidos: i) em presença de $24,9 \mathrm{~g} / \mathrm{t}$ de quitosana e de $6,3 \mathrm{~g} / \mathrm{t}$ de $\mathrm{AH}$ em água da torneira, ii) 24,9 g/t de quitosana e 6,3 g/t de AH em água Mili-Q; e iii) 24,9 g/t de quitosana em água Mili-Q. Os ensaios tiveram como objetivo comparar o efeito conjunto da quitosana com o $\mathrm{AH}$, com ou sem a presença de íons na água.

$\mathrm{O} \mathrm{pH}$ natural da polpa do rejeito de $\mathrm{Ni}$ é de 7,3, aproximadamente, e esse foi $\circ \mathrm{pH}$ definido para efeito de comparação da melhor adsorção para as três situações experimentais mencionadas anteriormente. No caso da floculação com quitosana e AH em água Mili-Q, observou-se o maior valor de turbidez (40 NTU), possivelmente devido a menor adsorção dos polímeros que está relacionada a cama elétrica. Para a floculação com quitosana e $\mathrm{AH}$ em água torneira, assim como para o uso somente de quitosana em agua Mili- $Q$, os resultados de turbidez foram semelhantes (33 NTU). Para valores de $\mathrm{pH}$ próximos da neutralidade o ácido húmico, aparentemente não sofreu influência dos íons presentes na água da torneira, possivelmente porque as suas constates de dissociação estão situadas em pH 6 e 8. 


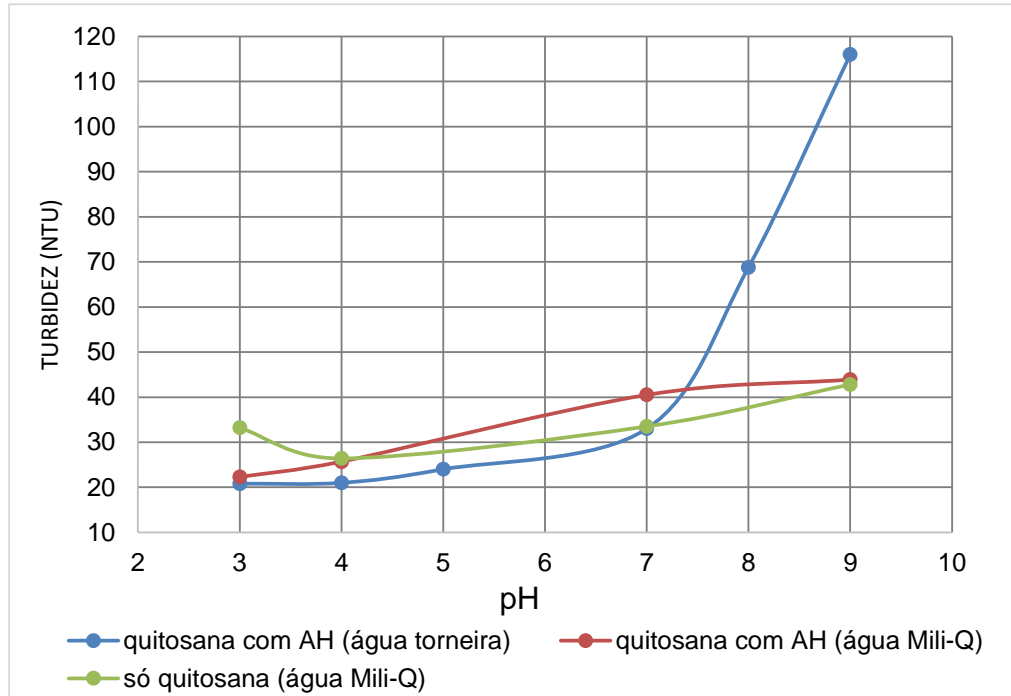

Figura 68 Floculação de rejeito de níquel (2,15\% de sólidos): i) em presença de quitosana $(24,9 \mathrm{~g} / \mathrm{t})$ e de $\mathrm{AH}(6,3 \mathrm{~g} / \mathrm{t})$ em água da torneira, ii) quitosana $(24,9 \mathrm{~g} / \mathrm{t})$ e de $\mathrm{AH}(6,3 \mathrm{~g} / \mathrm{t})$ em água Mili-Q; e iii) quitosana $(24,9 \mathrm{~g} / \mathrm{t})$ em água Mili-Q, em 119 rpm, no jar test.

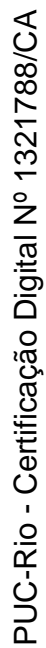

Na Figura 69, mostram-se as floculações a diferentes pH com os parâmetros otimizados, em água da torneira. 


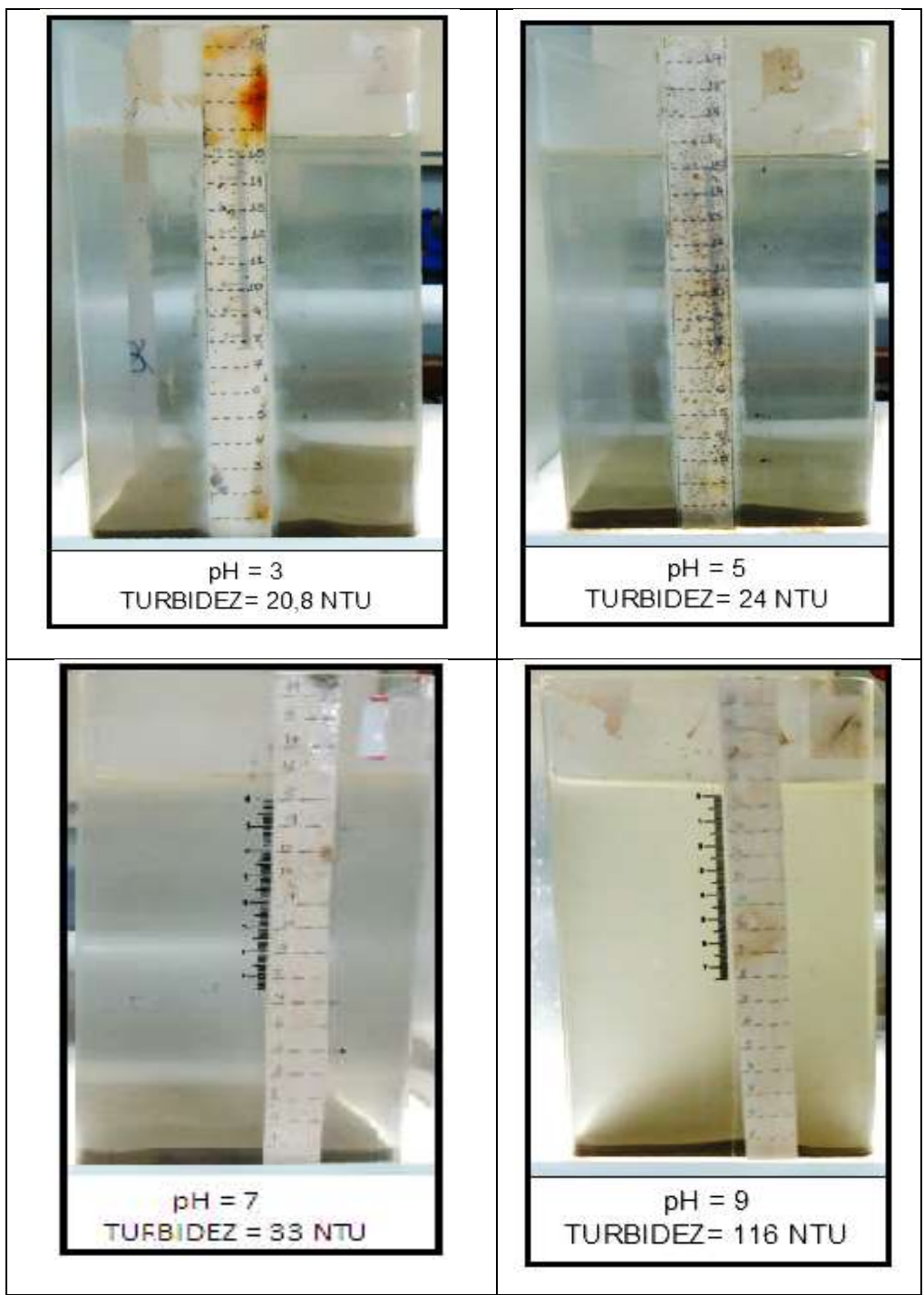

Figura 69 Floculações do rejeito de $\mathrm{Ni}$ em diferentes pHs, com quitosana $(24,9 \mathrm{~g} / \mathrm{t})$ e com $\mathrm{AH}(6,3 \mathrm{~g} / \mathrm{t})$.

\subsubsection{Floculação com diferentes ácidos húmicos (AH`s)}

Realizaram-se testes de floculação com os parâmetros otimizados (Tabela 15), em diferentes $\mathrm{pH}$ de 3, 4 e 7, com diferentes ácidos húmicos:

> Ácido húmico extraído do carvão (gerado pela PUC).

$>$ Ácido húmico extraído do coque (gerado pela PUC).

> Ácido húmico extraído do río (gerado pela IHSS).

> Ácido húmico standard pahokee (gerado pela IHHS).

Como pode-se observar na Figura 70 , se realizaram os testes de floculação do rejeito de $\mathrm{Ni}$ com 24,9 g/t, no $\mathrm{pH}$ de 3 é o que gerou o resultado de mais baixa turbidez com o ácido húmico extraído do carvão, apresentando uma turbidez de 
15 NTU. No pH de 4, o melhor resultado foi obtido com o ácido húmico extraído do coque, apresentando uma turbidez de 15 NTU; no pH de 7 o ácido húmico extraído da Aldrich foi o reagente que promoveu a menor turbidez, de 33 NTU. Em uma visão geral, a ação conjunta do acido húmico e da quitosana foi mais efetiva na faixa ácida de $\mathrm{pH}$.

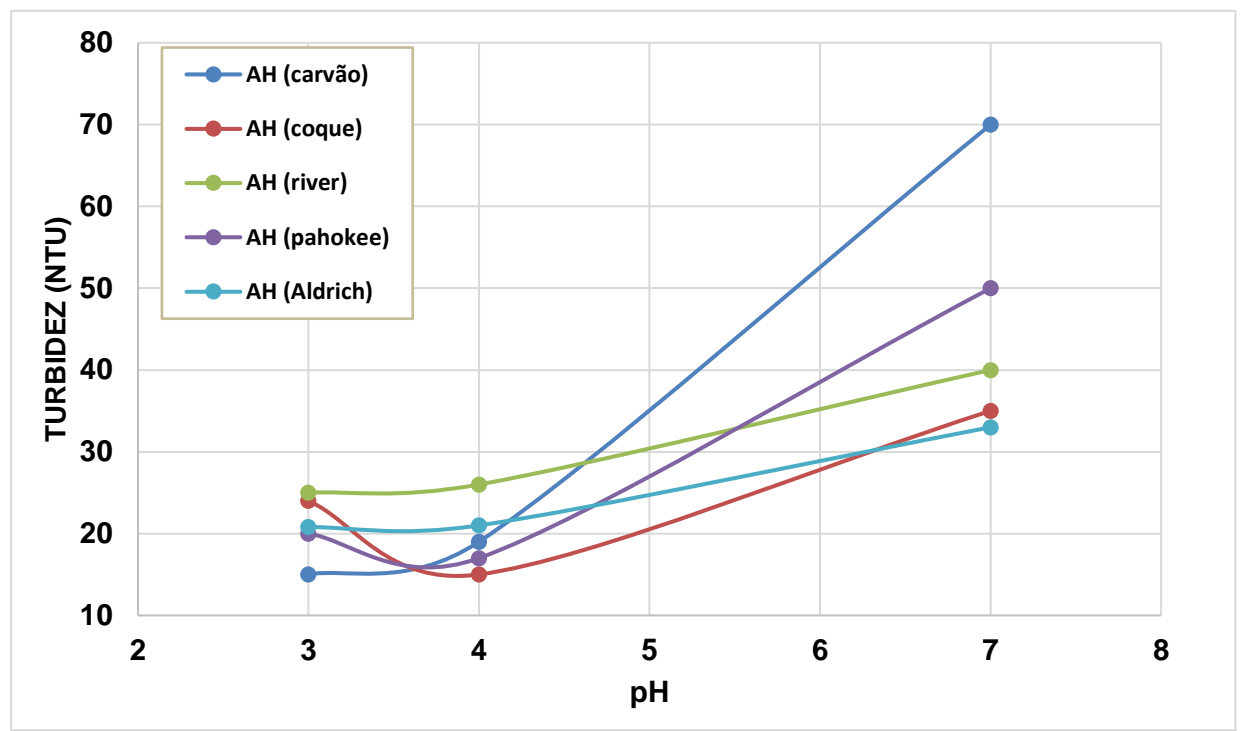

Figura 70 Floculação do rejeito de Ni (2,15\%), com quitosana $(24,9 \mathrm{~g} / \mathrm{t})$ e de ácido húmico (6,3 g/t), em 119 rpm, no jar test.

Na Figura 71 e 72 se apresentam as floculações executadas no jar test, em pH de 3 e 7 respectivamente, a fim de presenciar a eficiência da floculação na faixa ácida, baseado nas condições dos parâmetros otimizados. 


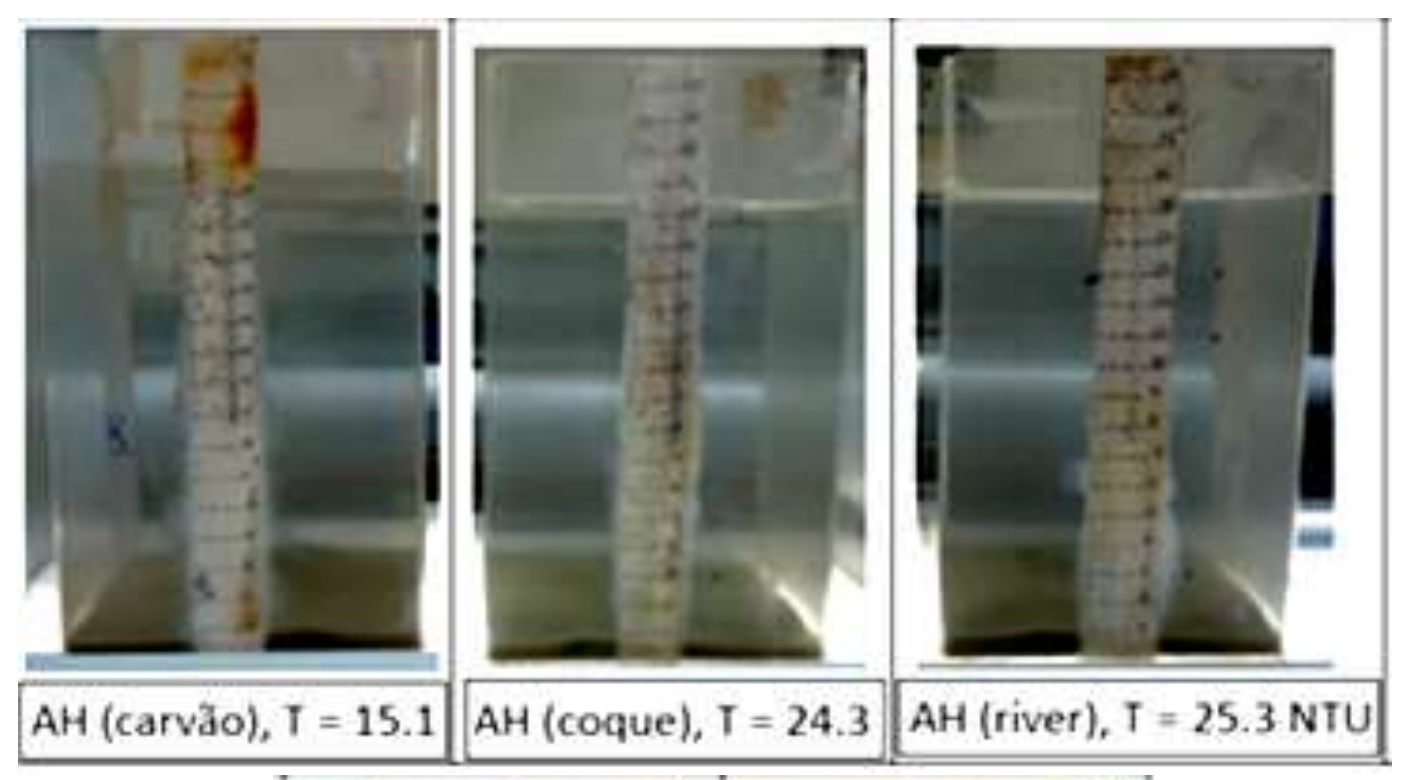

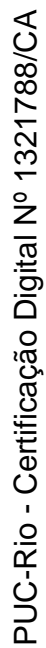

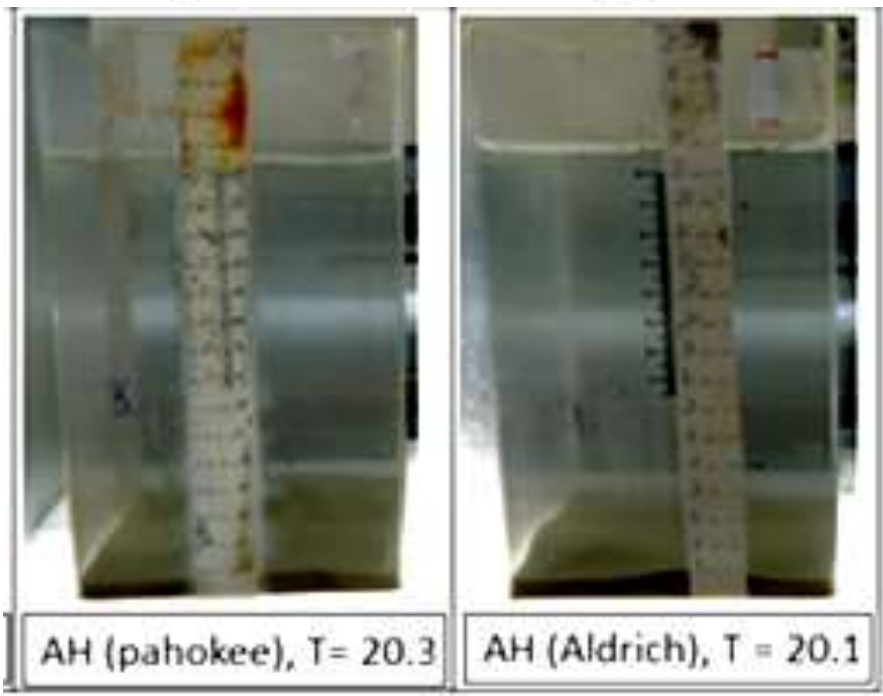

Figura 71 Floculação do rejeito de $\mathrm{Ni}$ em pH 3, quitosana $(24,9 \mathrm{~g} / \mathrm{t})$ e ácido húmico $(6,3 \mathrm{~g} / \mathrm{t})$. 


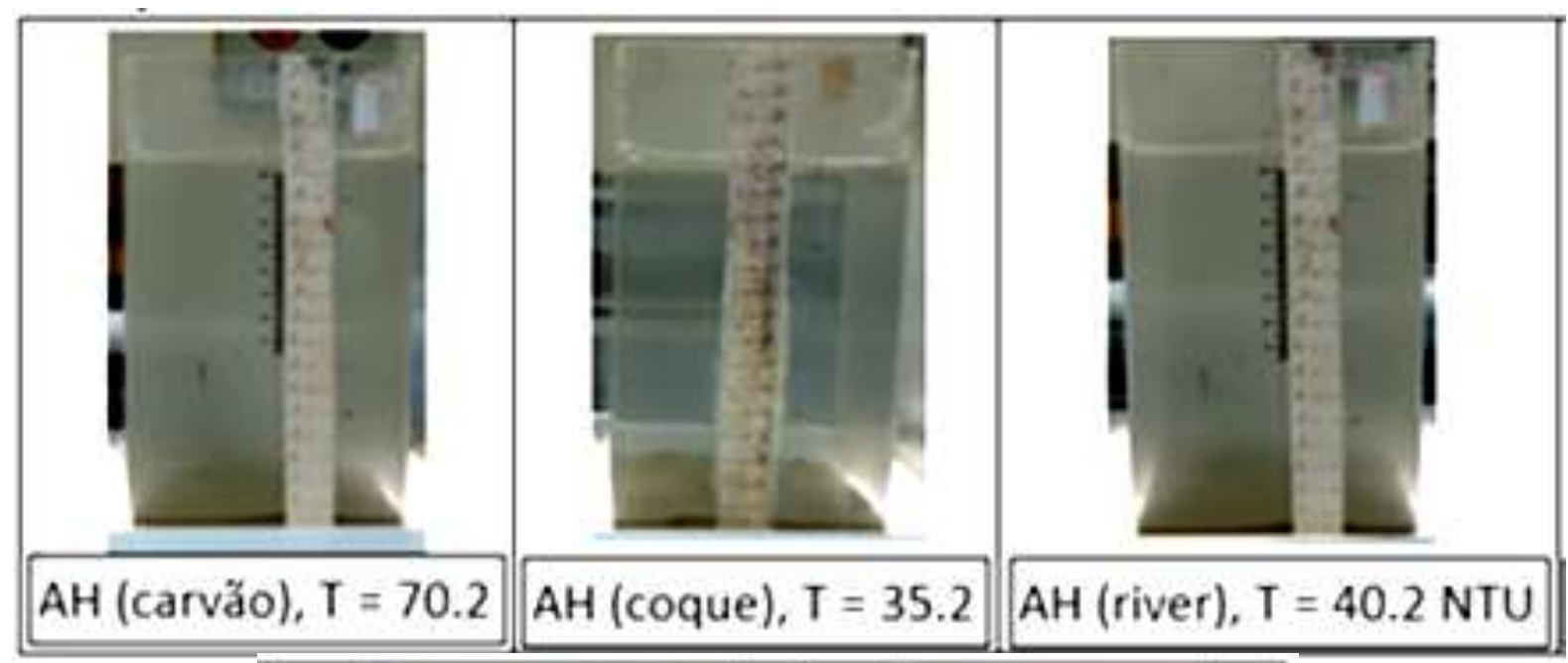

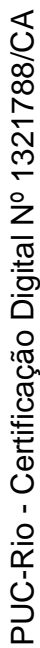

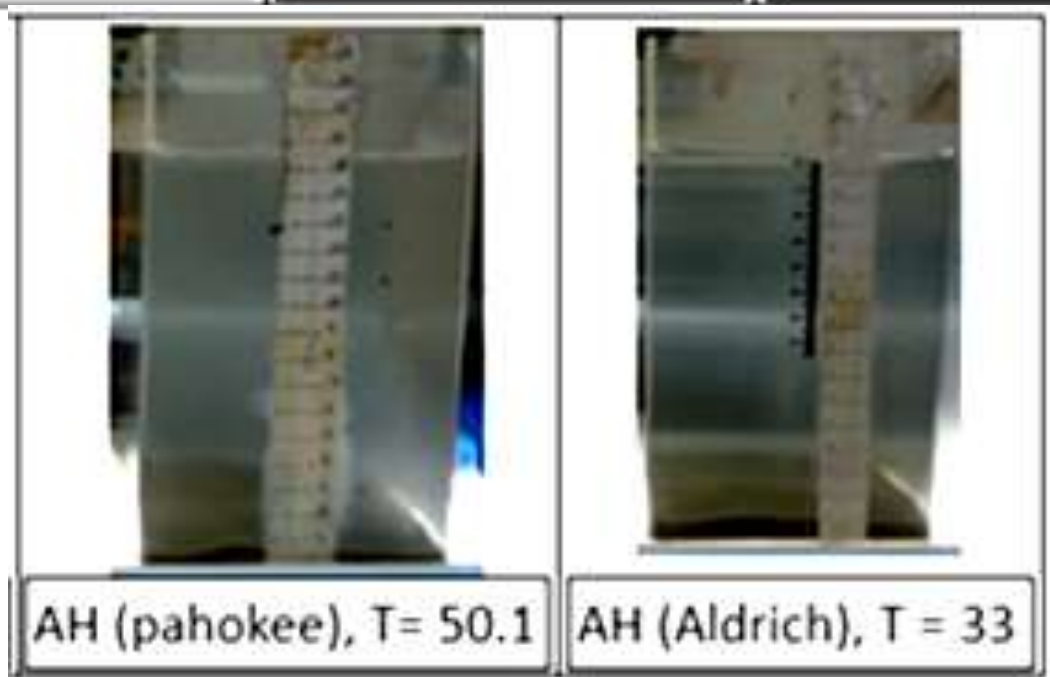

Figura 72 Floculação do rejeito de $\mathrm{Ni}$ em pH 7, quitosana $(24,9 \mathrm{~g} / \mathrm{t})$ e ácido húmico $(6,3 \mathrm{~g} / \mathrm{t})$.

\subsection{Caracterização da lama vermelha}

\subsubsection{Análise Química}

A Tabela 18 apresenta os resultados de análise química para a lama vermelha, e a Tabela 19 apresenta os resultados de picnometria e umidade. Em (ANEXO 9) encontra-se os dados do cálculo da densidade. 
Tabela 18 Análise química da lama vermelha.

\begin{tabular}{|c|c|}
\hline Elemento & Concentração (\%) \\
\hline $\mathrm{Al}$ & 10,5 \\
\hline $\mathrm{Si}$ & 16,9 \\
\hline $\mathrm{Ca}$ & 0,81 \\
\hline $\mathrm{Fe}$ & 21,6 \\
\hline $\mathrm{Na}$ & 8,3 \\
\hline $\mathrm{Ti}$ & 7 \\
\hline $\mathrm{Mn}$ & 0,04 \\
\hline
\end{tabular}

Tabela 19 Densidade e umidade da lama vermelha.

\begin{tabular}{|l|c|}
\hline \multicolumn{1}{|c|}{ Resultado } & $\begin{array}{c}\text { Lama } \\
\text { vermelha }\end{array}$ \\
\hline Densidade real $\left(\mathrm{kg} / \mathrm{m}^{3}\right) \pm 2.10^{-6} \mathrm{~kg}$ & 1.941 \\
\hline Umidade $(\%)$ & 15,3 \\
\hline
\end{tabular}

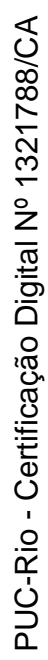

\subsubsection{Análise granulométrica}

Na Figura 73 se apresenta a distribuição granulométrica da lama vermelha, a qual apresenta uma distribuição de tamanho de partículas com $\mathrm{d}(0,2)$ $=2,2 \mu \mathrm{m}, \mathrm{d}(0,5)=6,0 \mu \mathrm{m}$ e $\mathrm{d}(0,9)=30 \mu \mathrm{m}$, indicando que a presença de colóides na polpa da lama vermelha, é de $20 \%$, os quais só podem ser removidos com o auxílio do processo de floculação. No ANEXO 10, estão os dados de tamanho de partícula $(\mu \mathrm{m})$.

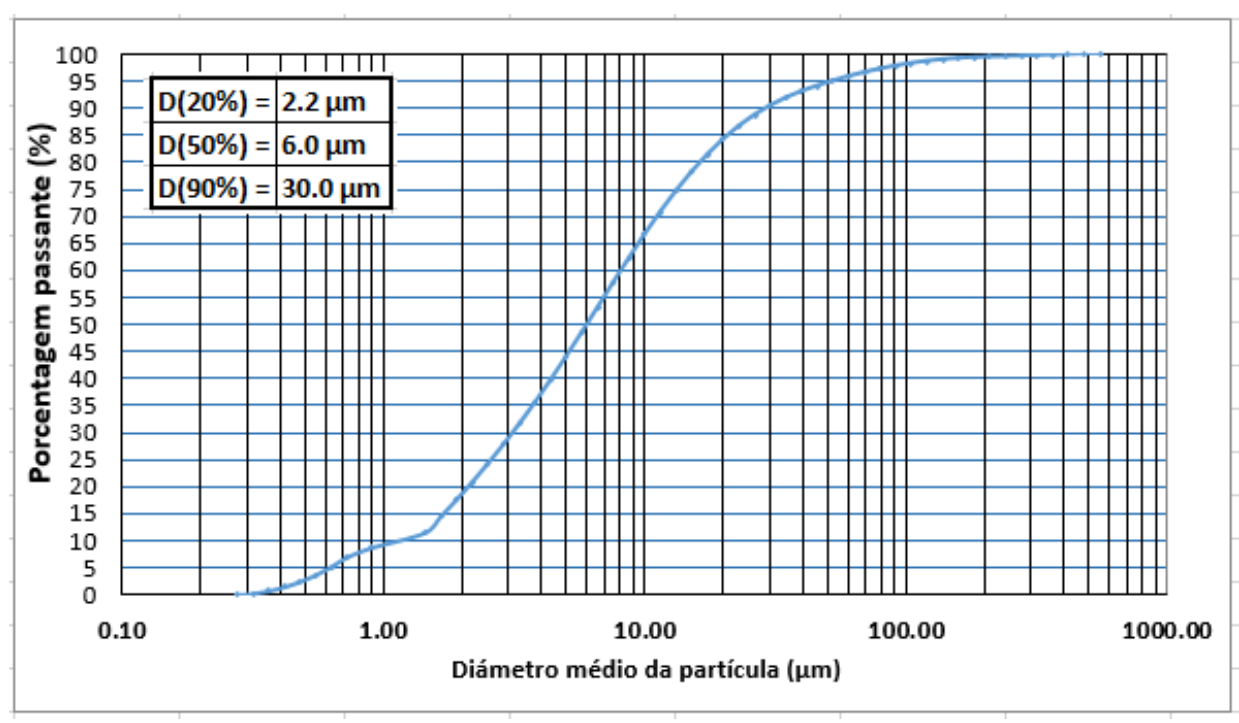

Figura 73 Distribuição granulométrica da lama vermelha 


\subsubsection{Difração de Raios $X$}

Para a amostra de lama natural (Figura 74), observa-se uma proporção relevante de gibbsita, mas não contém caulinita. Minerais carreadores de ferro e de titânio estão presentes, como goethita, hematita e anatásio. Sodalita é o principal silicato identificado, sugere-se a presença de calcita, devido ao aparecimento do seu pico principal.

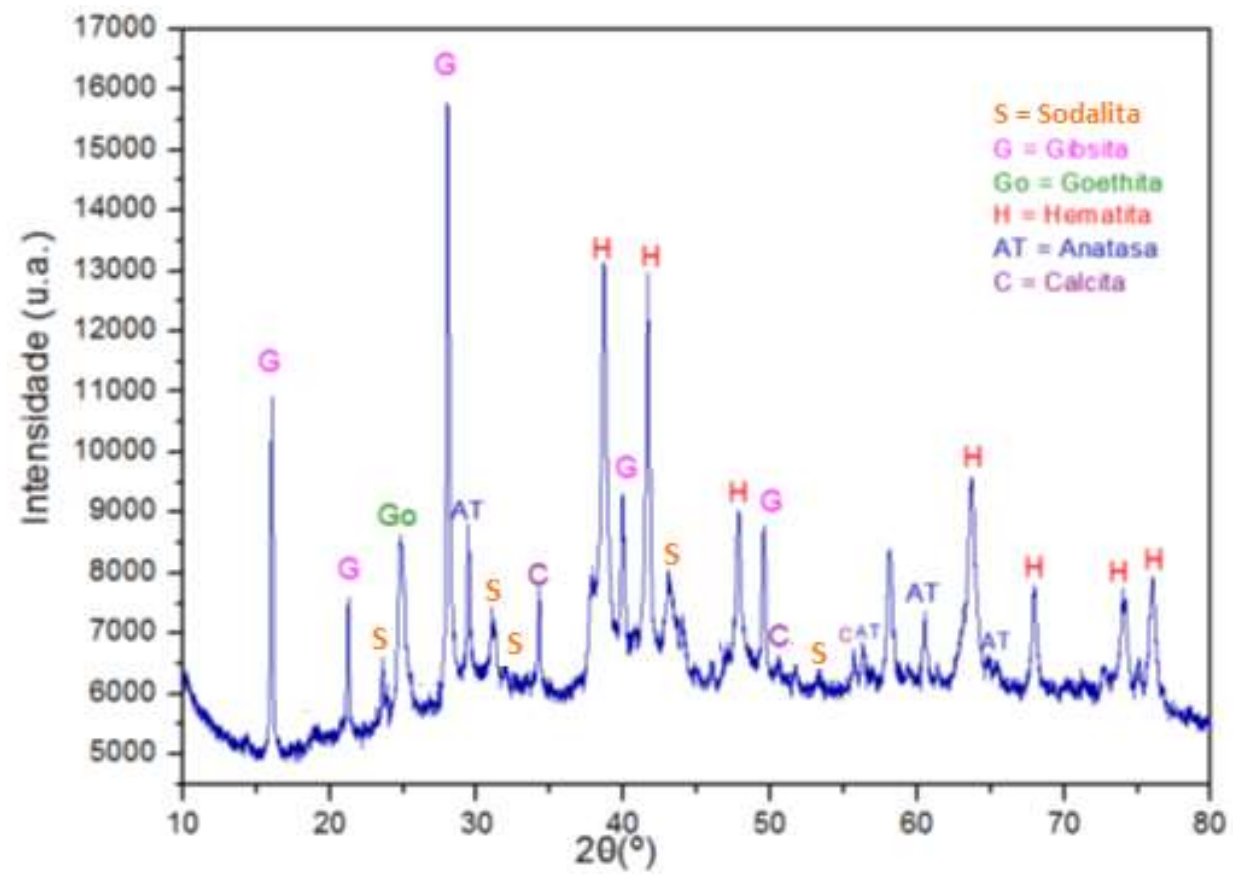

Figura 74 Espectro de DRX para a lama vermelha

\subsubsection{Microscopia Eletrônica de Varredura}

A micrografia das partículas finas $(-20 \mu \mathrm{m})$, de lama vermelha apresentadas na Figura 75, apresenta como característica principal uma morfologia nodular porosa e lamelar lisa. Para avaliar a força de agregação das partículas, realizaramse testes de floculação em função do pH. Na Figura 76, mostra-se a micrografía da floculação da polpa em $\mathrm{pH} 5$, na qual reflete uma maior agregação de partículas, pela redução da dupla camada elétrica, do que na floculação realizada em $\mathrm{pH}$ 12, (Figura 77), onde as partículas, mostram-se desestabilizadas para agregar-se, mas em uma magnitude de menor força de agregação. 


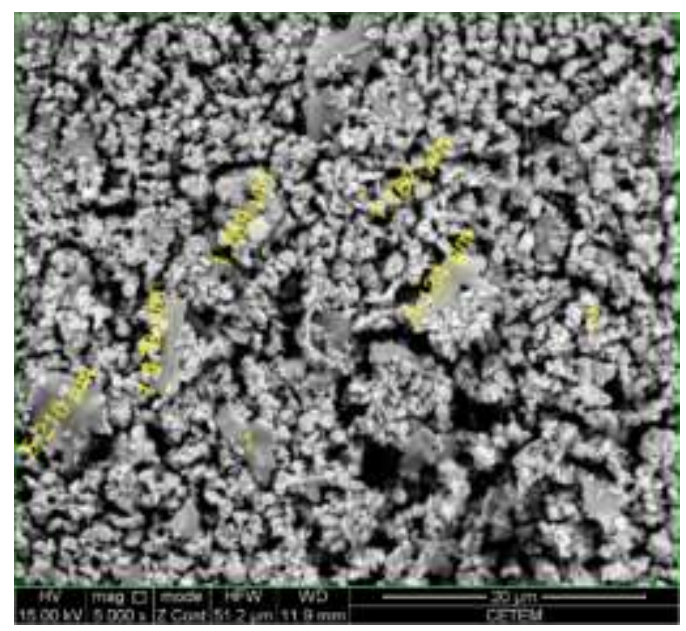

Figura 75 Micrografia das partículas de lama vermelha $(-20 \mu \mathrm{m})$

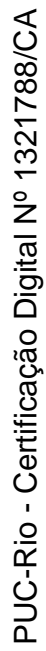

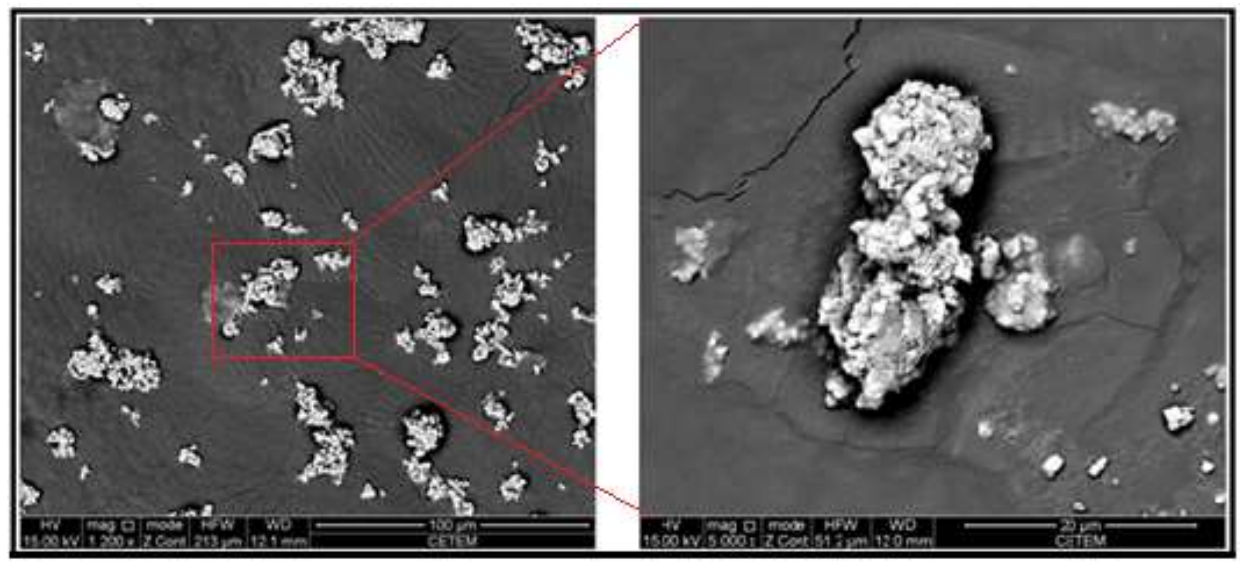

Figura 76 Micrografias das partículas de lama vermelha (-20 $\mu \mathrm{m})$, polpa em $\mathrm{pH} 5$

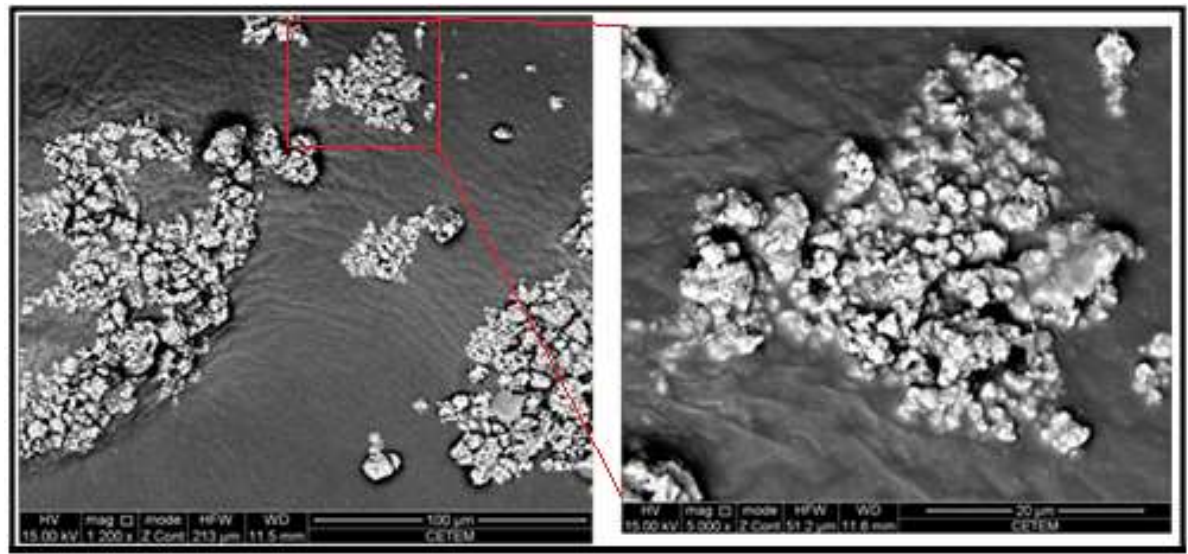

Figura 77 Micrografias das partículas de lama vermelha $(-20 \mu \mathrm{m})$, polpa em $\mathrm{pH} 12$ 


\subsubsection{Interação eletrostática}

$\mathrm{Na}$ Figura 78 se apresenta as medidas de cargas superficiales do $\mathrm{AH}$, quitosana e lama vermelha, a interpretação das medidas de cargas superficiais resultantes do $\mathrm{AH}$ e da quitosana foram interpretadas no item 6.5.5.

No caso da lama vermelha, o $\mathrm{pH}$ natural da polpa está na faixa de 10.2 $<\mathrm{pH}<10.5$. Essa amostra, por se tratar de um rejeito contém partículas de diferentes minerais, se podem observar que apresenta dois pontos isoelétricos, em $\mathrm{pH}=5.5$ e em um pH próximo a 12.5, mostrando uma aproximação do potencial zeta; a lama vermelha apresenta uma zona coloidal estável na faixa de $\mathrm{pH}$ de 9 a 11.5. Acima do $\mathrm{pH}=5.5$, as partículas da lama vermelha mostram uma reversão de cargas, de negativas para positivas e também observou-se que o eletrolito é indiferente.

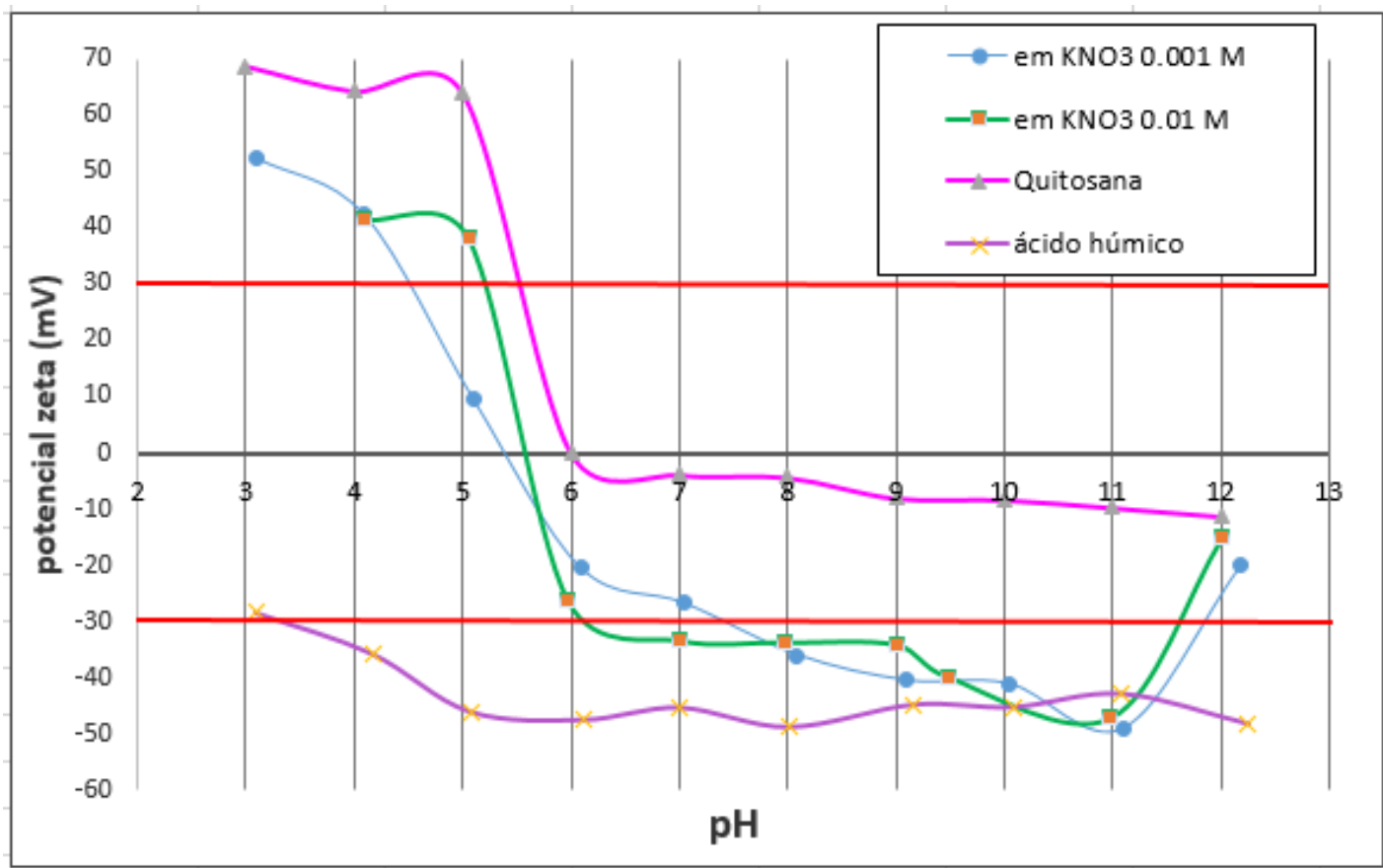

Figura 78 Potencial zeta da lama vermelha em granulometria menor a 20 $\mu \mathrm{m}$ e com eletrólito de $0,001 \mathrm{M}$ e $0,01 \mathrm{M} \mathrm{KNO}_{3}$ e quitosana (solução pura a 1000 ppm) e do ácido húmico (solução pura a 100 ppm), em água Mili-Q. 


\subsubsection{Determinação de tamanho de agregados (flocos) em função do $\mathrm{pH}$}

A Figura 79 apresenta os resultados do tamanho médio das partículas em função do pH para a lama vermelha. Na região próxima ao ponto isoelétrico, na faixa básica, em pH 12, o material apresenta maior tamanho de partícula, mostrando a possível aglomeração das mesmas, devido à neutralização das cargas superficiais; o mesmo pode ser observado em $\mathrm{pH}$ 8, e a região próxima ao segundo ponto isoelétrico, na faixa ácida entre o pH de 5 e 6 (Figura 78), mostram também uma maior agregação de partículas, e maior ainda na faixa de $\mathrm{pH}$ de 2 a 4.

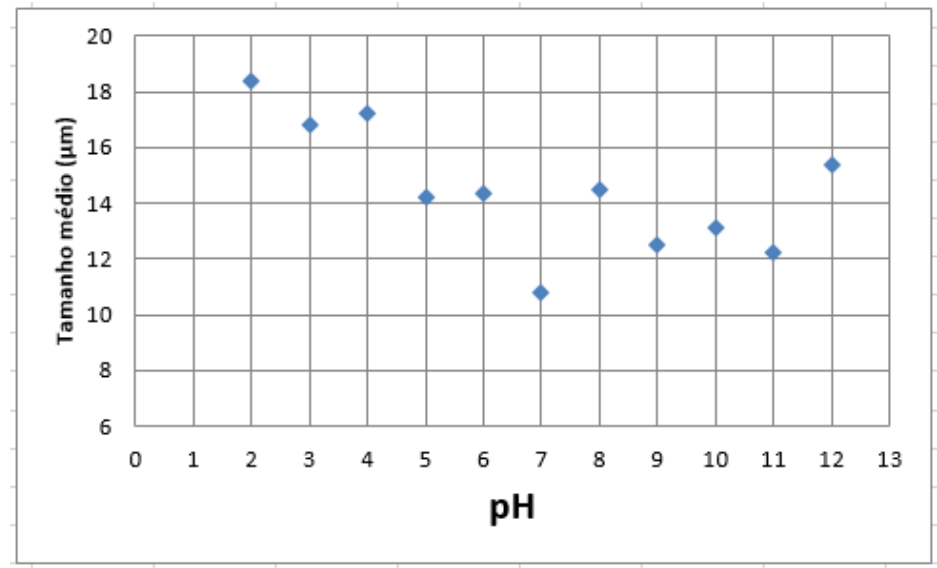

Figura 79 Agregação de partículas da lama vermelha (0.1\%) em função do pH, no Malvern Mastersizer 2000P, em água Mili-Q.

\subsubsection{Pre-testes de floculação}

Baseado nas análises de caracterização, interação eletrostática e aglomerados de tamanhos de partículas, se realizaram pre-testes de floculação para ajustar os parâmetros do planejamento experimental. A turbidez média das polpas naturais (sem floculação, agitação em jar test a 225 rpm) estudadas situase na faixa dos 550 NTU, (Figura 80). 


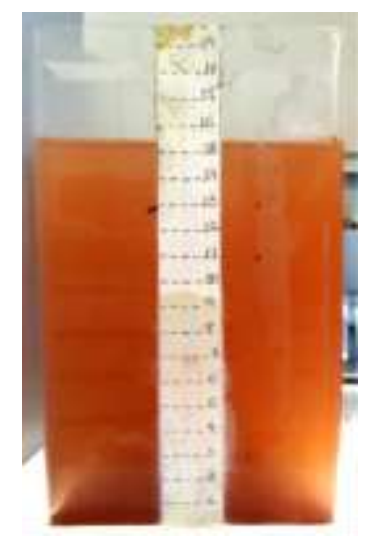

Figura 80 Turbidez da polpa da lama vermelha (0,25\% de sólidos), sem flocular (550 NTU).

\subsubsection{Efeito da quitosana e do ácido húmico em pH 12}

$\mathrm{Na}$ Figura 81, pode-se observar os testes de floculação, em diferentes dosagens de quitosana e ácido húmico em uma polpa de $1 \%$ de sólidos em pH 12, na qual é evidenciado que sem presença de $A H$, a quitosana tem uma adsorção nas partículas proporcional com o aumento da sua dosagem, enquanto que quando foi adicionado $6,4 \mathrm{~g} / \mathrm{t}$ do $\mathrm{AH}$, a turbidez reduciu-se á metade do que sem $\mathrm{AH}$, e ao aumento da dosagem do $\mathrm{AH}$, em os diferentes dosagens da quitosana, não foi evidenciado uma melhora na redução da turbidez. Porém, como se pode observar na Figura 81, uma resposta de turbidez ótima de 35 NTU, foi com dosagem de $515 \mathrm{~g} / \mathrm{t}$ de quitosana e de $6,4 \mathrm{~g} / \mathrm{t}$ de $\mathrm{AH}$.

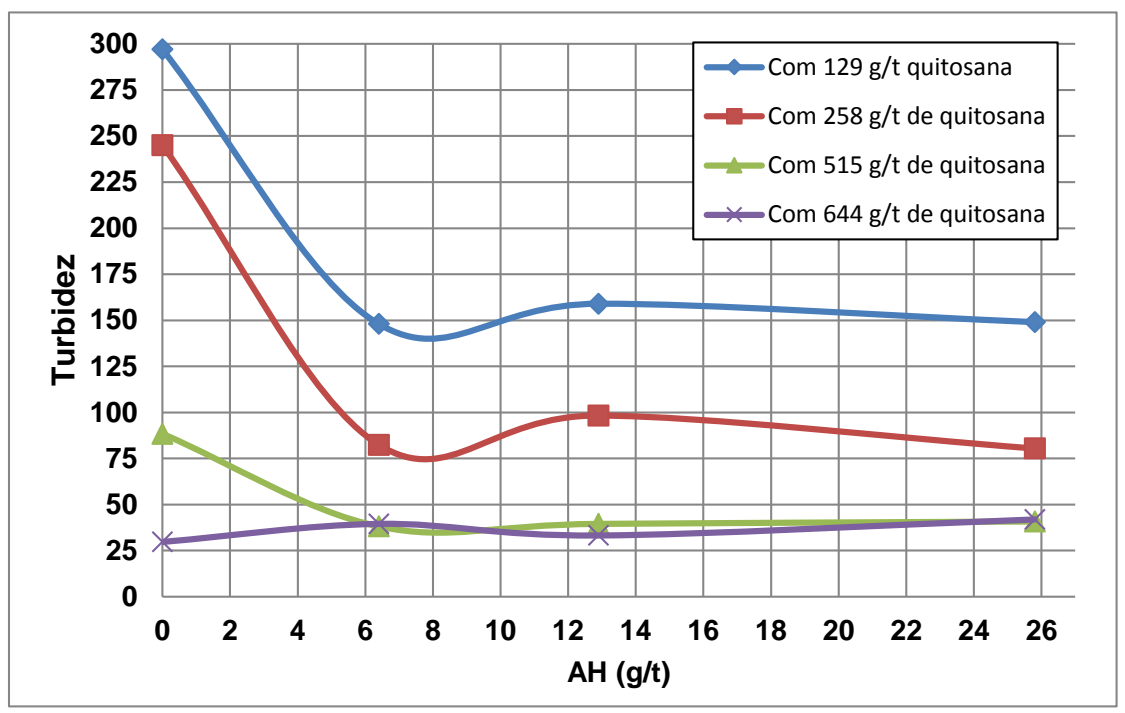

Figura 81 Adsorção da quitosana e do ácido húmico em diferentes dosagens na lama vermelha (1\%) em pH 12, em 225 rpm, no jar test. 


\subsubsection{Efeito dos cátions da água na floculação}

Com o objetivo de analizar a influencia dos íons na água da torneira sobre a desestabilização das cargas da lama vermelha em $\mathrm{pH} 12$, foram realizados testes com água de torneira e com água Mili-Q. A dosagem de $\mathrm{AH}$ foi constante para todos os testes de 6,4 g/t. Pode-se observar na Figura 82, que a influência dos cátions na adsorção partículas-polímero, foi mínima, para toda a faixa de dosagem de polímeros avaliada.

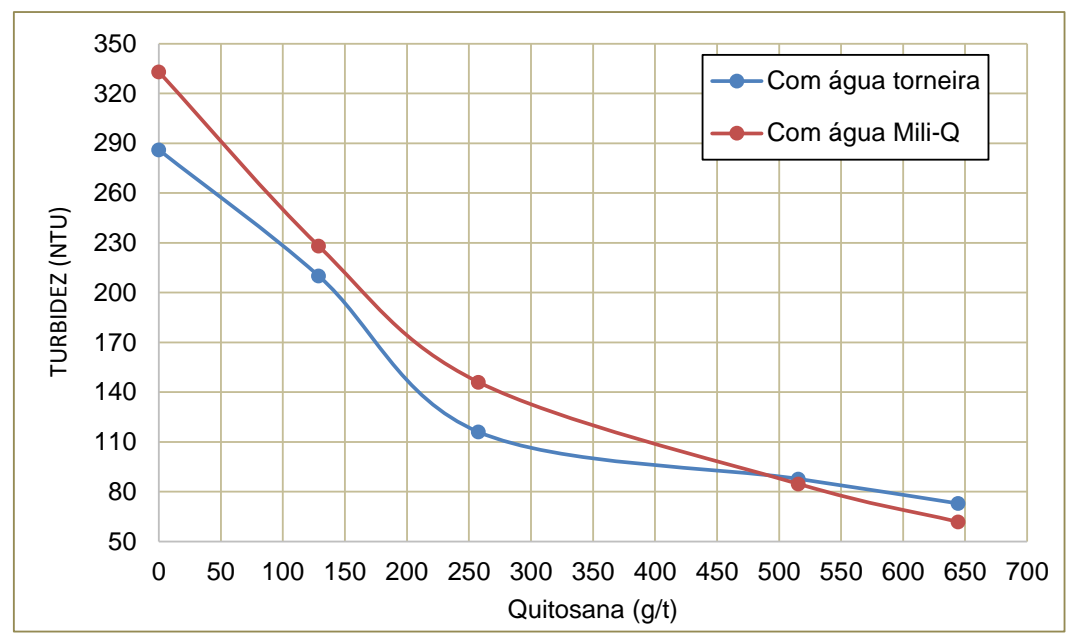

Figura 82 Adsorção da quitosana $(680 \mathrm{~g} / \mathrm{t})$ na lama vermelha $(0,25 \%$ de sólidos), em pH 12, em 225 rpm, no jar test.

\subsubsection{Desenvolvimento do planejamento experimental para a lama vermelha a $\mathrm{pH} 12$}

Os resultados da turbidez para cada teste do planejamento experimental da lama vermelha são mostrados na Tabela 20 , com três pontos centrais. 
Tabela 20 Planejamento experimental para a lama vermelha, em pH 12.

\begin{tabular}{|c|c|c|c|c|c|c|}
\hline & $\begin{array}{l}\text { Conc. de } \\
\text { sólidos (\%) }\end{array}$ & $\begin{array}{l}\text { Quitosana } \\
(\mathrm{g} / \mathrm{t})\end{array}$ & $\begin{array}{c}\mathrm{AH} \\
(\mathrm{g} / \mathrm{t})\end{array}$ & $\begin{array}{l}\text { Velocidade de } \\
\text { agitação (rpm) }\end{array}$ & $\begin{array}{c}\text { Tempo de } \\
\text { agitação (min) }\end{array}$ & $\begin{array}{c}\text { Turbidez } \\
\text { (NTU) }\end{array}$ \\
\hline Teste & $A$ & B & $\mathrm{C}$ & D & $E$ & $\mathrm{Y}$ \\
\hline 1 & 0,5 & 650 & 8 & 175 & 1 & 58,0 \\
\hline 2 & 1 & 650 & 8 & 175 & 1 & 83,0 \\
\hline 3 & 0,5 & 1950 & 8 & 175 & 1 & 24,7 \\
\hline 4 & 1 & 1950 & 8 & 175 & 1 & 27,8 \\
\hline 5 & 0,5 & 650 & 16 & 175 & 1 & 66,6 \\
\hline 6 & 1 & 650 & 16 & 175 & 1 & 69,4 \\
\hline 7 & 0,5 & 1950 & 16 & 175 & 1 & 21,8 \\
\hline 8 & 1 & 1950 & 16 & 175 & 1 & 27,4 \\
\hline 9 & 0,5 & 650 & 8 & 275 & 1 & 75,6 \\
\hline 10 & 1 & 650 & 8 & 275 & 1 & 102,0 \\
\hline 11 & 0,5 & 1950 & 8 & 275 & 1 & 25,6 \\
\hline 12 & 1 & 1950 & 8 & 275 & 1 & 41,3 \\
\hline 13 & 0,5 & 650 & 16 & 275 & 1 & 68,9 \\
\hline 14 & 1 & 650 & 16 & 275 & 1 & 86,4 \\
\hline 15 & 0,5 & 1950 & 16 & 275 & 1 & 24,9 \\
\hline 16 & 1 & 1950 & 16 & 275 & 1 & 38,5 \\
\hline 17 & 0,5 & 650 & 8 & 175 & 3 & 58,0 \\
\hline 18 & 1 & 650 & 8 & 175 & 3 & 74,8 \\
\hline 19 & 0,5 & 1950 & 8 & 175 & 3 & 23,8 \\
\hline 20 & 1 & 1950 & 8 & 175 & 3 & 49,0 \\
\hline 21 & 0,5 & 650 & 16 & 175 & 3 & 47,2 \\
\hline 22 & 1 & 650 & 16 & 175 & 3 & 71,0 \\
\hline 23 & 0,5 & 1950 & 16 & 175 & 3 & 25,6 \\
\hline 24 & 1 & 1950 & 16 & 175 & 3 & 60,3 \\
\hline 25 & 0,5 & 650 & 8 & 275 & 3 & 46,9 \\
\hline 26 & 1 & 650 & 8 & 275 & 3 & 96,1 \\
\hline 27 & 0,5 & 1950 & 8 & 275 & 3 & 30,6 \\
\hline 28 & 1 & 1950 & 8 & 275 & 3 & 80,4 \\
\hline 29 & 0,5 & 650 & 16 & 275 & 3 & 55,3 \\
\hline 30 & 1 & 650 & 16 & 275 & 3 & 110,0 \\
\hline 31 & 0,5 & 1950 & 16 & 275 & 3 & 35,7 \\
\hline 32 & 1 & 1950 & 16 & 275 & 3 & 80,1 \\
\hline 33 & 0,75 & 1300 & 14 & 225 & 2 & 50,6 \\
\hline 34 & 0,75 & 1300 & 14 & 225 & 2 & 51,8 \\
\hline 35 & 0,75 & 1300 & 14 & 225 & 2 & 52,2 \\
\hline
\end{tabular}

\subsubsection{Análise da variância com réplicas no ponto central}

a) Média dos testes (exceto pontos centrais):

$$
\bar{Y}=55,83 \text { NTU }
$$


b) Média dos pontos centrais:

$$
\bar{y}=51,53 \mathrm{NTU}
$$

Para o cálculo dos efeitos de cada tratamento se multiplica a transposta da matriz codificada (Tabela 2), pela matriz das respostas da variável dependente (turbidez). E para o cálculo da soma de quadrados dos efeitos de cada tratamento, se utiliza a Equação (21). Os resultados são apresentados na Tabela 44 (ANEXO 11).

Baseado nos cálculos realizados na Tabela 45 (ANEXO 12), a análise da variância se apresenta na Tabela 21, para os testes com a lama vermelha, que determina os efeitos significativos.

Tabela 21 Análise da variância para os testes com a lama vermelha

\begin{tabular}{|c|c|c|c|c|}
\hline Fator & SSxj & g.I & MSSxj & Fo \\
\hline A & 5208,4 & 1 & 5208,38 & 7512,1 \\
\hline B & 9513,4 & 1 & 9513,38 & 13721,2 \\
\hline C & 2,2 & 1 & 2,23 & 3,2 \\
\hline D & 1377,5 & 1 & 1377,47 & 1986,7 \\
\hline E & 331,2 & 1 & 331,21 & 477,7 \\
\hline AB & 18,2 & 1 & 18,23 & 26,3 \\
\hline AC & 6,2 & 1 & 6,17 & 8,9 \\
\hline AD & 564,1 & 1 & 564,06 & 813,5 \\
\hline AE & 1115,7 & 1 & 1115,69 & 1609,2 \\
\hline BC & 29,5 & 1 & 29,55 & 42,6 \\
\hline BD & 8,5 & 1 & 8,46 & 12,2 \\
\hline BE & 1302,4 & 1 & 1302,41 & 1878,5 \\
\hline CD & 3,8 & 1 & 3,82 & 5,5 \\
\hline CE & 111,2 & 1 & 111,19 & 160,4 \\
\hline DE & 52,1 & 1 & 52,15 & 75,2 \\
\hline ABCDE & 0,6 & 1 & 0,65 & 0,9 \\
\hline Curvatura & 50,6 & 1 & 50,64 & 73,03 \\
\hline Error & 1,4 & 2 & $\mathbf{0 , 6 9}$ & \\
\hline Total & 19697,1 & 19 & & \\
\hline
\end{tabular}

Uma variável ou interação é significativa se: $F o>F(\alpha g l, g l e)$. Das tabelas de distribuição de Fisher, donde $\alpha=0,01, g l=1, g l e=2$, a um nível de significância do $99 \%$, o valor de $\mathrm{F}_{0.01}$ é 98.5 (Ver ANEXO 19).

Porém, pode observar na Tabela 21 que as variáveis significativas são: $A$ (contração de sólidos), B ( dosagem de quitosana), D (velocidade de agitação), E 
(tempo de agitação), e as inteações: AD (concentração de sólidos-velocidade de agitação), $\mathrm{AE}$ (concentração de sólidos-tempo de agitação), BE (quitosana-tempo de agitação) e CE (ácido húmico-tempo de agitação); Além disso, o modelo não apresenta um efeito de curvatura, portanto, o modelo linear se ajusta adequadamente aos dados experimentais estabelecidas no planejamento experimental.

\subsubsection{Obtenção do modelo matemático para a lama vermelha}

Os coeficientes do modelo matemático são apresentados pela Equação (24):

$$
\text { Turbidez }=55,8+12,8 A-17,2 B+6,6 D+3,2 E+4,2 A D+5,9 A E+6,4 B E+
$$$$
1,9 C E
$$

Pelo cálculo da análise de resíduos da Tabela 46 (ANEXO 13), verifica-se que o modelo seja apropriado aos dados experimentais, se cumpre-se a condição: Fo $<\mathrm{F}$ ( $\alpha$, gl, gle), a Equação (25) apresenta a soma de quadrados residual do modelo:

$$
S S M_{R}=\frac{\sum_{i=1}^{n_{0}}(Y-\hat{Y})^{2}}{N r-I}
$$

$$
\mathrm{SSM}_{\mathrm{R}}=34,75
$$

O modelo é adequado se: Fo < F( $\alpha$ glr,gle $)$, da Tabela 25, calcule-se Fo, dando um valor de: $\mathrm{Fo}=50,11$

Das tabelas de distribuição de Fisher, encontra-se que: $F(0.01,23,2), F=99,46$, como: 50,11<99,46. Então verificou-se que o modelo matemático se ajusta aos dados do planejamento experimental.

\subsubsection{Decodificação do modelo matemático para a lama vermelha}

Para a decodificação do modelo, se determinou o raio e o centro do desenho, conforme a Tabela 47 (ANEXO 14).

Determinou-se, ainda, o termo independente e os termos lineares, mediante as equações apresentadas na Tabela 5.

O modelo decodificado é representado, então, pela Equação (26): 
Turbidez $=174,9-71,8 A-0,092 B-0,1 D-39,2 E+0,3 A D+23,6 A E+$

$$
0,02 B E+0,5 C E
$$

\subsubsection{Diagrama de Pareto}

Com base no diagrama de Pareto (Figura 83), para a lama vermelha, notase que as principais variáveis com influência sobre a turbidez são: $A$ (concentração de sólidos), $\mathrm{D}$ (velocidade de agitação), e $\mathrm{E}$ (tempo de agitação), apresentam efeito positivo, para o aumento da turbidez, B (dosagem de quitosana), apresenta um efeito negativo para diminuir a turbidez, e como interações entre as variáveis temse: $B E$ (quitosana-tempo de agitação), $A E$ (concentração de sólidos-tempo de agitação), AD (concentração de sólidos-velocidade de agitação) e CE (dosagem de ácido húmico-tempo de agitação), apresentando um efeito positivo, ou seja um efeito sinérgico que ao aumentar o efeito conjunto de seus fatores aumenta o resultado da turbidez.

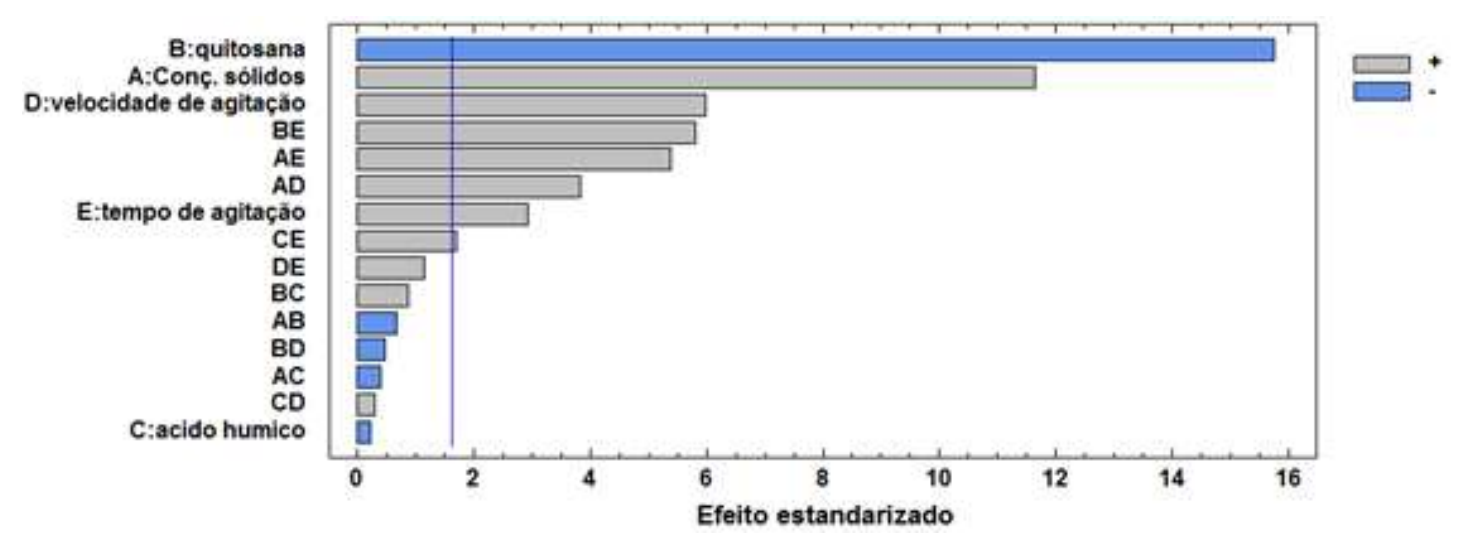

Figura 83 Diagrama de Pareto a pH 12.

\subsubsection{Efeitos principais da turbidez}

Na Figura 84, apresentam-se os efeitos principais da turbidez, com relação à concentração de sólidos, velocidade e o tempo de agitação apresentam uma inclinação positiva, o que apresenta uma relação diretamente proporcional com a turbidez, dando um valor alto nesses fatores maior será a turbidez. Para o ácido húmico, nota-se um efeito quase constante, mostrando a pequena influência dessa variável sobre a variável de resposta, tanto no nível baixo quanto no nível alto do planejamento. Já a quitosana apresentou um efeito negativo, o que indica que existe uma relação inversamente proporcional com relação à turbidez, ou 
seja, quanto maior a quantidade de quitosana adicionada na floculação, menor será a turbidez residual do sobrenadante.

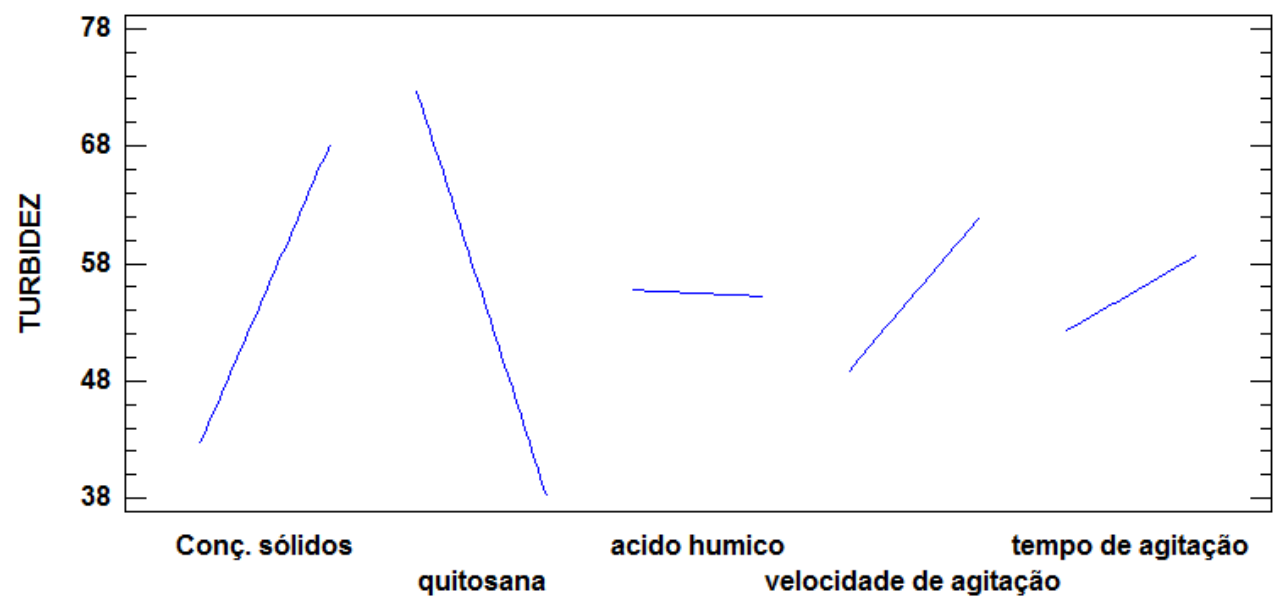

Figura 84 Efeitos principais da turbidez.

\subsubsection{Diagramas de superficie}

Na Figura 85 se observa que mantendo a velocidade e o tempo de agitação no nível médio, apresenta que para obter 36 NTU, a concentração de sólidos devese manter no nível mais baixo, a quitosana e o $\mathrm{AH}$, devem-se manter em nível alto.

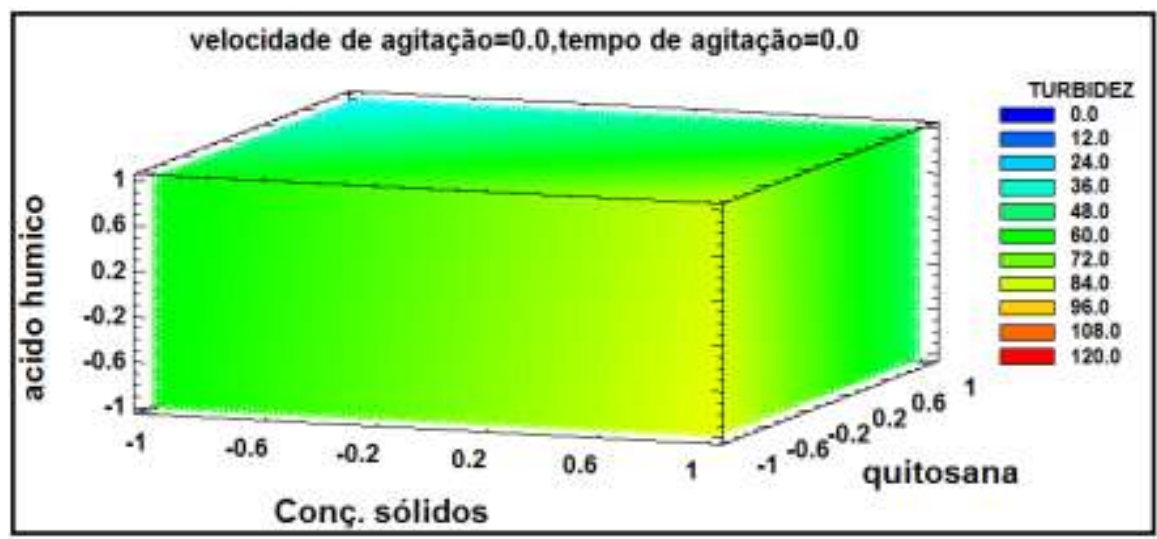

Figura 85 Diagrama de superfície AH-Conc de sólidos-Quitosana.

$\mathrm{Na}$ Figura 86, mantendo $\mathrm{AH}$ e o tempo de agitação no nível médio, apresenta que para obter 36 NTU, a concentração de sólidos deve-se manter no nível mais baixo, a velocidade de agitação em nível alto e a quitosana deve-se manter em níveis altos. 


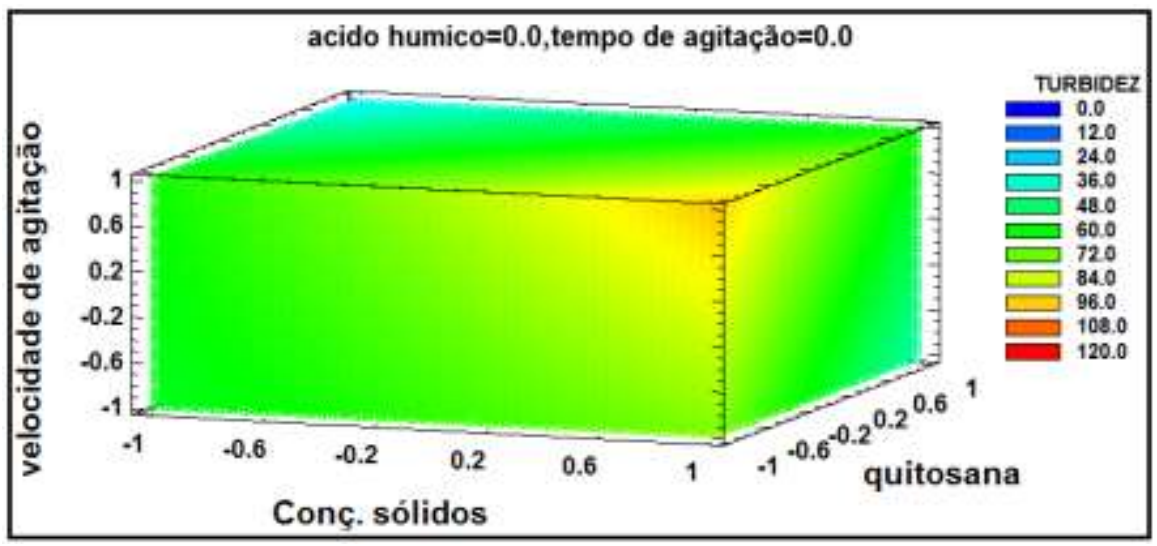

Figura 86 Diagrama de superfície Veloc. de agitação-Conc de sólidosquitosana.

Na Figura 87, mantendo o $\mathrm{AH}$ e a velocidade de agitação no nível médio, apresenta que para obter 36 NTU, a concentração de sólidos deve-se manter no nível mais baixo, o tempo agitação em nível alto e a quitosana deve-se manter em níveil alto.

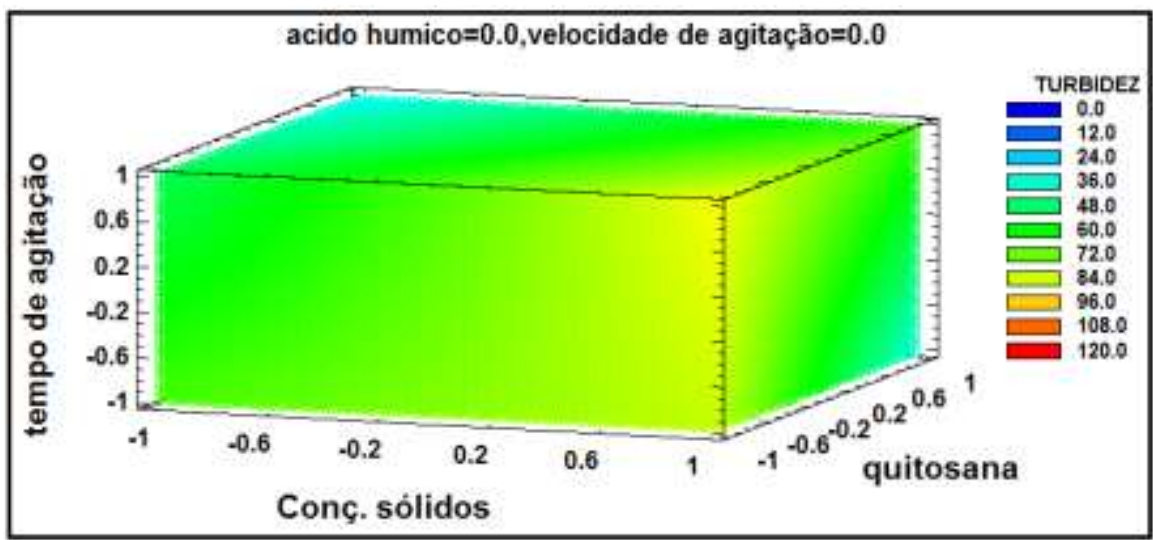

Figura 87 Diagrama de superfície Tempo de agitação-Conc de sólidosquitosana.

Na Figura 88, mantendo a quitosana e o tempo de agitação no nível médio, apresenta que para obter 48 NTU aproximadamente, a concentração de sólidos deve-se manter no nível mais baixo, a velocidade de agitação e o $\mathrm{AH}$ em nível baixo. 


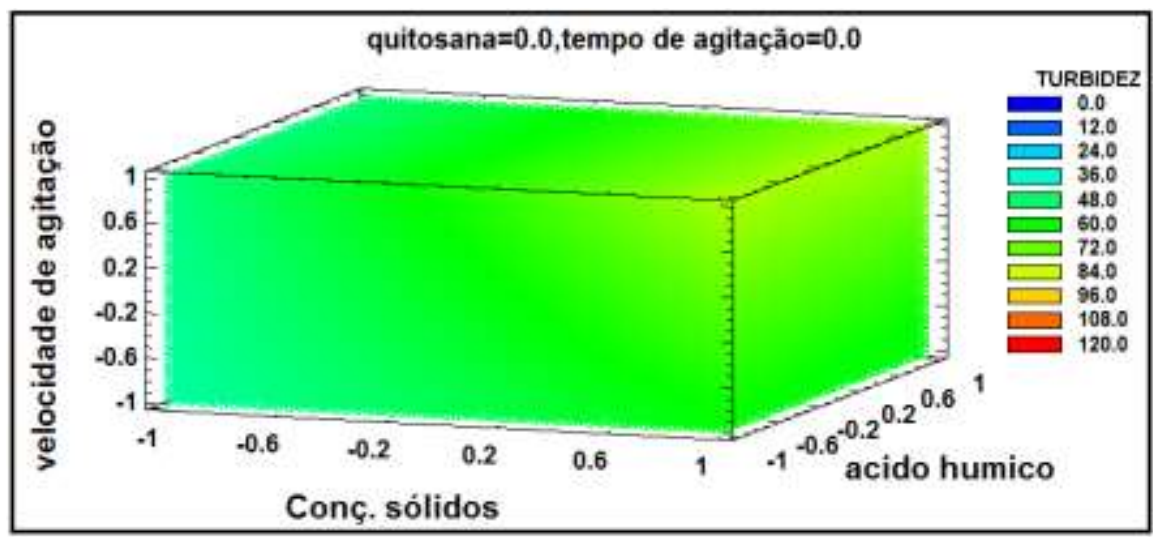

Figura 88 Diagrama de superfície Veloc. de agitação-Conc de sólidos-AH.

Na Figura 89, mantendo a quitosana e a velocidade de agitação no nível médio, apresenta que para obter 40 NTU aproximadamente, a concentração de sólidos e o $\mathrm{AH}$ devem-se manter no nível mais baixo, e o tempo de agitação em nível alto.

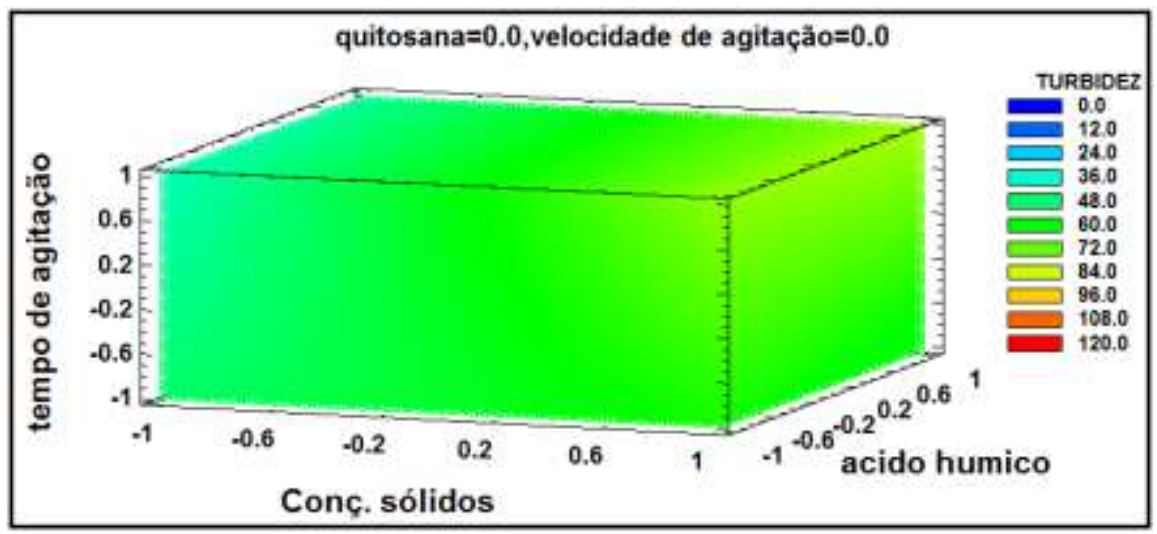

Figura 89 Diagrama de superfície Tempo de agitação-Conc de sólidos-AH.

\subsubsection{Otimização de parâmetros com o modelo Simplex}

O modelo Simplex é utilizado para otimizar os parâmetros do modelo de primer ordem, baseado nas equações do ITEM 5.1.9.2 para o cálculo dos parâmetros de otimização, cada cálculo de turbidez foi realizado com o modelo decodificado, o objetivo desta optimização é ajustar os parametros do planejamento experimental para uma turbidez embaixo dos 40 NTU. Na Tabela 22 mostra-se os resultados dos 6 vértices do modelo Simplex com suas respectivas respostas de turbidez: 
Tabela 22 Cálculo do vértice 7

\begin{tabular}{|c|c|c|c|c|c|c|}
\hline Vértice & ZA & ZB & ZC & ZD & ZE & Y (Turbidez) \\
\hline $\mathbf{1}$ & 0,88 & 1068,93 & 12,82 & 232,9 & 2,13 & 71,81 \\
\hline $\mathbf{2}$ & 0,63 & 1068,93 & 12,82 & 232,9 & 2,13 & 57,63 \\
\hline $\mathbf{3}$ & 0,75 & 787,15 & 12,82 & 232,9 & 2,13 & 78,88 \\
\hline $\mathbf{4}$ & 0,75 & 975 & 9,55 & 232,9 & 2,13 & 66,21 \\
\hline $\mathbf{5}$ & 0,75 & 975 & 12 & 193,4 & 2,13 & 63,46 \\
\hline $\mathbf{6}$ & 0,75 & 975 & 12 & 225 & 1,36 & 65,13 \\
\hline
\end{tabular}

Note-se na Tabela 22 a turbidez maior é do teste $\mathrm{n} \div$. 3, então deve-se encontrar o centro de gravidade para cada variável, como é apresentado na Tabela 23:

Tabela 23 Cálculo do primer centro de gravidade.

\begin{tabular}{|c|c|c|c|c|c|c|}
\hline Vértice & ZA & ZB & ZC & ZD & ZE & Y (Turbidez) \\
\hline $\mathbf{1}$ & 0,88 & 1068,93 & 12,82 & 232,9 & 2,13 & 71,81 \\
\hline $\mathbf{2}$ & 0,625 & 1068,93 & 12,82 & 232,9 & 2,13 & 57,63 \\
\hline $\mathbf{4}$ & 0,75 & 975 & 9,55 & 232,9 & 2,13 & 66,21 \\
\hline $\mathbf{5}$ & 0,75 & 975 & 12 & 193,4 & 2,13 & 63,46 \\
\hline $\mathbf{6}$ & 0,75 & 975 & 12 & 225 & 1,36 & 65,13 \\
\hline PROMEDIO & $\mathbf{0 , 7 5}$ & $\mathbf{1 0 1 2 , 5 7}$ & $\mathbf{1 1 , 8 4}$ & $\mathbf{2 2 3 , 4 2}$ & $\mathbf{1 , 9 7}$ & $\mathbf{6 4 , 8 5}$ \\
\hline
\end{tabular}

E logo deve-se encontrar o ponto de reflexão, ou seja, as coordenadas do novo vértice são:

$Z_{A}{ }^{r}=0,75 ; Z_{B}{ }^{r}=1237,9 ; Z_{C}{ }^{r}=10,9 ; Z_{D}{ }^{r}=213,1 ; Z_{E}^{r}=1,8$

Substitui-se no modelo decodificado, e o vértice 7 simplex é adicionada na nova matriz, em conjunto com os vértices $1,2,4,5$ e 6 , como é mostrado na Tabela 24:

Tabela 24 Cálculo do vértice 8.

\begin{tabular}{|c|c|c|c|c|c|c|}
\hline Vértice & ZA & ZB & ZC & ZD & ZE & Y (Turbidez) \\
\hline $\mathbf{1}$ & 0,875 & 1068,9 & 12,82 & 232,9 & 2,129 & 71,81 \\
\hline $\mathbf{2}$ & 0,625 & 1068,9 & 12,82 & 232,9 & 2,129 & 57,63 \\
\hline $\mathbf{4}$ & 0,75 & 975 & 9,552 & 232,9 & 2,129 & 66,21 \\
\hline $\mathbf{5}$ & 0,75 & 975 & 12 & 193,4 & 2,129 & 63,46 \\
\hline $\mathbf{6}$ & 0,75 & 975 & 12 & 225 & 1,355 & 65,13 \\
\hline $\mathbf{7}$ & 0,75 & 1238 & 10,86 & 213,9 & 1,819 & 49,38 \\
\hline
\end{tabular}

Note-se que o maior valor de turbidez foi observado no teste $\mathrm{n}$ 1 , assim sucessivamente se calcularam novos vértices até chegar ao resultado de turbidez 
menor do que 40 NTU. Note-se que na Tabela 25, no vértice 12, encontraram-se a resposta de turbidez desejada de 35,1 NTU.

Tabela 25 Cálculo do vértice 12

\begin{tabular}{|c|c|c|c|c|c|c|}
\hline Vértice & ZA & ZB & ZC & ZD & ZE & Y (Turbidez) \\
\hline $\mathbf{7}$ & 0,8 & 1238,0 & 10,9 & 213,9 & 1,8 & 49,4 \\
\hline $\mathbf{8}$ & 0,6 & 1023,8 & 10,1 & 206,4 & 1,7 & 52,8 \\
\hline $\mathbf{9}$ & 0,6 & 1137,3 & 13,5 & 195,7 & 1,5 & 49,2 \\
\hline $\mathbf{1 0}$ & 0,6 & 1202,2 & 11,7 & 191,9 & 2,4 & 45,2 \\
\hline $\mathbf{1 1}$ & 0,5 & 1293,1 & 11,6 & 223,0 & 1,7 & 36,5 \\
\hline $\mathbf{1 2}$ & 0,6 & 1289 & 10 & 179 & 1,5 & 35,1 \\
\hline
\end{tabular}

A otimização de parâmetros foi realizada em função dos requerimentos da norma CONAMA 357 (Silva, 2005), para valores de turbidez menores do que 40 NTU. Embora os testes tenham sido realizados em pH 12, que não se encaixa na faixa de $\mathrm{pH}$ (6-9) exigida pela legislação para descarte do efluente tratado, os valores obtidos para a turbidez do sobrenadante permitem que o mesmo seja reutilizado na usina de beneficiamento mineral, reduzindo a necessidade de captação de água nova no ambiente. Os dados otimizados para o processo são apresentados na Tabela 26.

Tabela 26 Parâmetros optimizados da lama vermelha para uma turbidez de 35 NTU

\begin{tabular}{|l|c|}
\hline Variável & Parâmetro \\
\hline Concent. Sólidos & $0,6 \%$ \\
\hline Dosagem quitosana & $1289 \mathrm{~g} / \mathrm{t}$ \\
\hline Dosagem AH & $10 \mathrm{~g} / \mathrm{t}$ \\
\hline Velocidade de agitação rápida & $179 \mathrm{rpm}$ \\
\hline Tempo de agitação rápido & $1 \mathrm{~min} 30 \mathrm{~s}$. \\
\hline
\end{tabular}

\subsubsection{Testes de floculação com os parámetros otimizados}

O teste de floculação foi realizado com base nos parâmetros otimizados para o pH=12 (Tabela 26), e não foi condizente com o previsto pelo modelo simplex. Observou-se na solução de quitosana, a presença de algumas fibrilas brancas no seio da solução, provavelmente devido à sua degradação, o que promoveu um resultado de menor eficiência de remoção da turbidez, (Figura 90). 


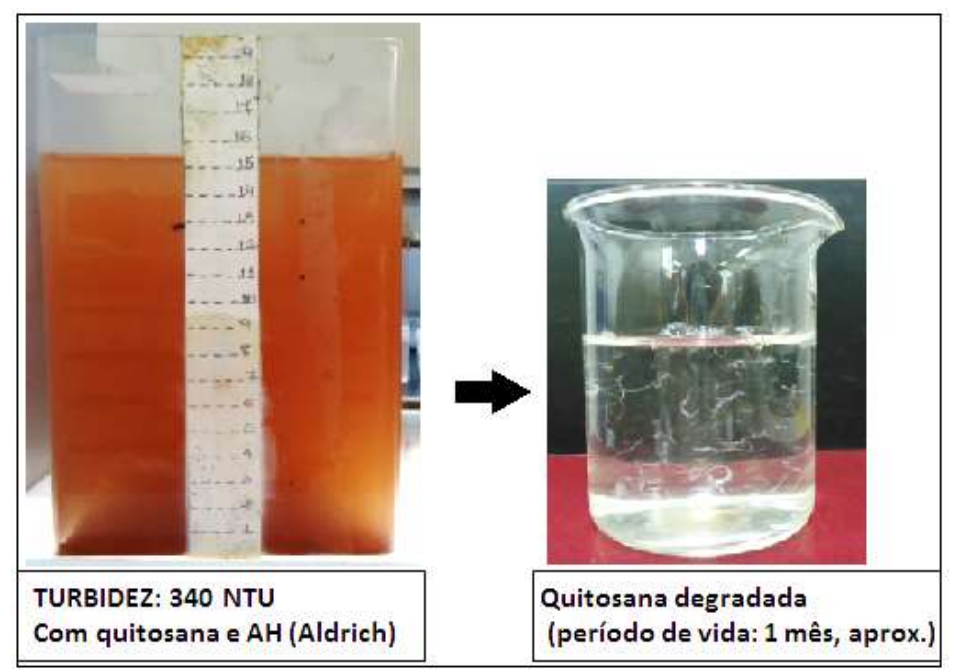

Figura 90 Floculação da lama vermelha ( $0,6 \%$ de sólidos), com quitosana (1289 g/t) e AH (10 g/t), em pH 12, em 179 rpm, no jar test.

Com a preparação de uma nova solução de quitosana a 1000 ppm, se realizou novamente o teste de floculação: na presença de quitosana e ácido húmico, obteve-se um sobrenadante com turbidez de 33 NTU mostrando a influência positiva do efeito sinérgico entre a quitosana e o ácido húmido; quando se utilizou apenas a quitosana, a turbidez obtida foi de 49,5 NTU. (Figura 91).

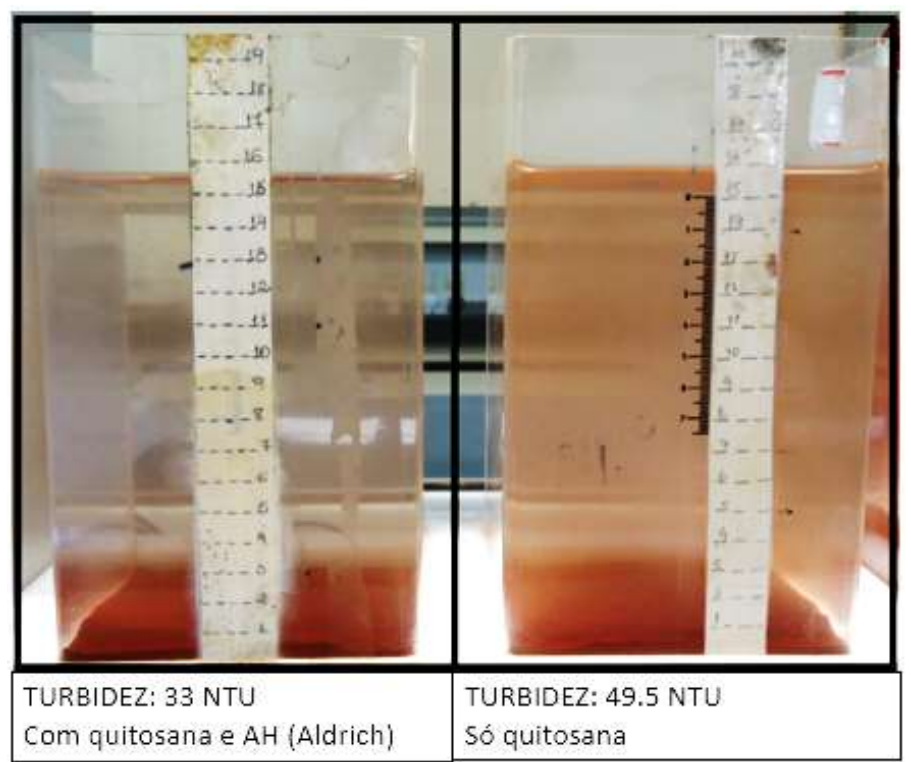

Figura 91 Floculação da lama vermelha (0,6\%), com quitosana (1289 g/t) e $\mathrm{AH}(10 \mathrm{~g} / \mathrm{t})$, e só com quitosana (1289 g/t), em $179 \mathrm{rpm}$, em $\mathrm{pH}=12$, no jar test. 


\subsubsection{Efeitos de floculação em função do pH}

Baseado nos parâmetros de otimização da lama vermelha, foram realizados testes comparativos, para analisar a eficiência de floculação em diferentes valores de $\mathrm{pH}$ (6 a 12) e avaliar o comportamento de desestabilização das partículas. Nesses testes foi também avaliada, a influência dos cátions presentes na água da torneira (geração de pontes partículas-polímeros). Os resultados desses testes foram comparados com os obtidos utilizando água Mili-Q (isenta de íons), para avaliação dos seguintes efeitos:

\subsubsection{Efeito de floculação com quitosana}

Na Figura 92, apresenta os resultados de experimentos realizados para dois tipos de floculação, com 0,6\% de sólidos, em presença de $1289 \mathrm{~g} / \mathrm{t}$ de quitosana, em água de torneira e em água Mili-Q. Em pH de 8 se obteve a melhor resposta de turbidez, em água Mili-Q que foi de 2.5 NTU aproximadamente. A presença de cátions presentes na água de torneira não foi relevante em meio ácido; na faixa de pH entre 10 e 12 pode-se considerar a inferência desses cátions na geração de pontes e consequente agregação de partículas, confirmada por uma redução de turbidez de 70 NTU (água Mili-Q) a 50 NTU (água da torneira).

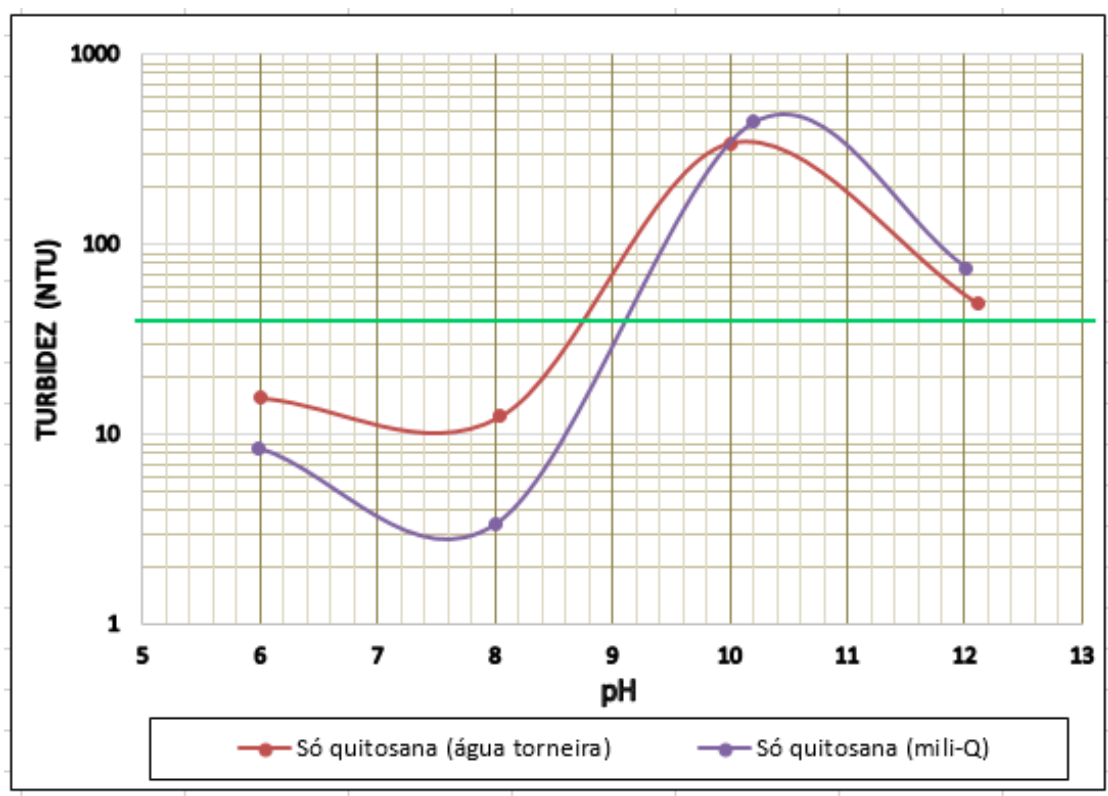

Figura 92 Floculação da lama vermelha (0,6\%), com quitosana (1289 g/t), em água da torneira e Mili-Q, em 179 rpm, no jar test. 


\subsubsection{Efeito de floculação com quitosana e AH}

A Figura 93, apresenta os resultados de dois ensaios de floculação, para polpas com com $0,6 \%$ de sólidos, preparadas em água da torneira, em presença de $1289 \mathrm{~g} / \mathrm{t}$ de quitosana e $10 \mathrm{~g} / \mathrm{t}$ de $\mathrm{AH}$. O melhor resultado foi obtido em $\mathrm{pH}=8$, com resposta de turbidez de 9 NTU com quitosana e AH em água de torneira, enquanto que no $\mathrm{pH}$ de 12 teve uma maior resposta de turbidez, de 33 NTU para a floculação com quitosana e AH e de 50 NTU da floculação só com quitosana. Finalmente em $\mathrm{pH}=12$ houve uma maior participação do $\mathrm{AH}$ do que na faixa ácida, possibilitando a obtenção de valores de turbidez dentro do exigido pela legislação ambiental, abaixo de 40 NTU (CONAMA 357)

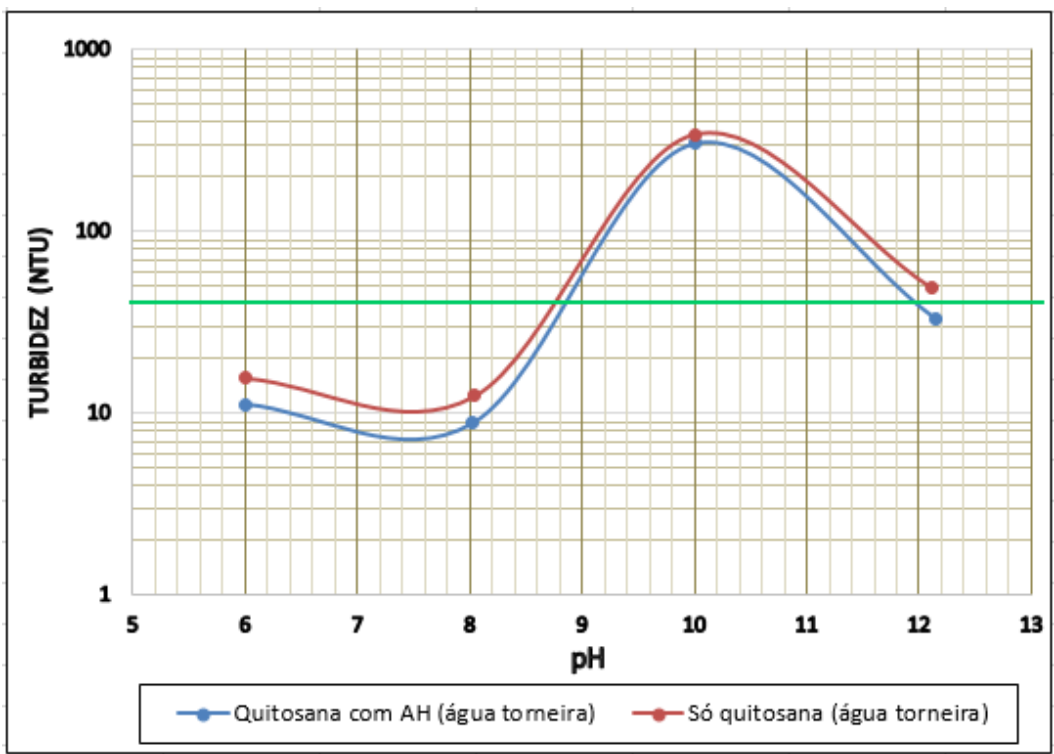

Figura 93 Floculação da lama vermelha (0,6\%), com quitosana (1289 g/t) e de $\mathrm{AH}(10 \mathrm{~g} / \mathrm{t})$ e só com quitosana $(1289 \mathrm{~g} / \mathrm{t})$ em água torneira, em $179 \mathrm{rpm}$, no jar test.

\subsubsection{Efeito de floculação com quitosana e AH em água torneira e água Mili-Q}

Na Figura 94, desenvolveram-se dois tipos de floculação: as polpas foram preparadas na concentração de $0,6 \%$ de sólidos, em água da torneira e em água Mili-Q, separadamente, na presença de $1289 \mathrm{~g} / \mathrm{t}$ de quitosana e $10 \mathrm{~g} / \mathrm{t}$ de $\mathrm{AH}$. O objetivo desses ensaios foi avaliara influência dos cátions presentes na água da torneira. Em $\mathrm{pH}=8$ se obteve a melhor resposta de turbidez, que foi de 3 NTU para floculação com quitosana e $\mathrm{AH}$ em água Mili-Q. No $\mathrm{pH}=12$, para floculações com 
quitosana e AH, obteve-se uma turbidez de 45 NTU em água Mili-Q e de 33 NTU para água torneira. Esse resultado pode ser explicado pela maior participação dos cátions presentes da água da torneira na faixa básica do que na faixa ácida, como pode-se observar na Figura 94.

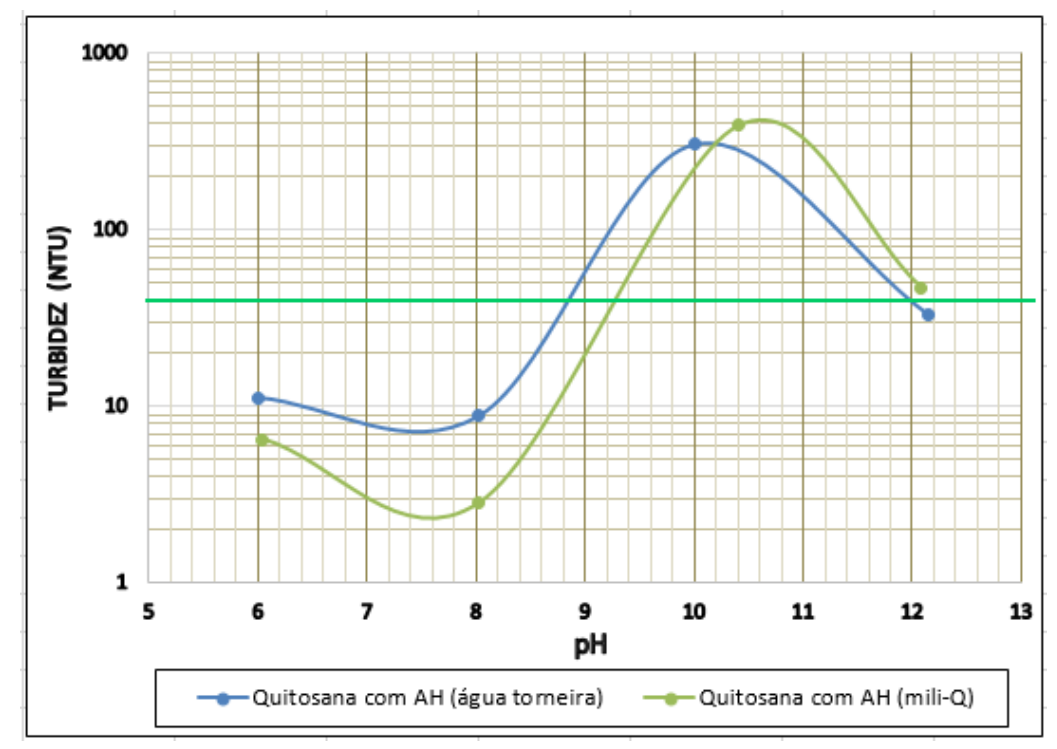

Figura 94 Floculação da lama vermelha (0.6\%), com quitosana $(1289 \mathrm{~g} / \mathrm{t}) \mathrm{e}$ $\mathrm{AH}(10 \mathrm{~g} / \mathrm{t})$, em água torneira e em água Mili-Q, em 179 rpm, no jar test.

\subsubsection{Efeito da floculação com quitosana e $\mathrm{AH}$ em água de torneira, com quitosana e AH em água Mili-Q e só com quitosana em água Mili-Q}

$\mathrm{Na}$ Figura 95, desenvolveram-se tres tipos de floculação, com $0.6 \%$ de sólidos, em presença de $1289 \mathrm{~g} / \mathrm{t}$ de quitosana e $10 \mathrm{~g} / \mathrm{t}$ de $\mathrm{AH}$ em água da torneira, com $1289 \mathrm{~g} / \mathrm{t}$ de quitosana e $10 \mathrm{~g} / \mathrm{t}$ de $\mathrm{AH}$ em água Mili-Q, e em $1289 \mathrm{~g} / \mathrm{t}$ de quitosana em água Mili-Q. Em pH=12 obteve-se uma resposta de turbidez de 70 NTU para floculação com quitosana, para a floculação com quitosana e $\mathrm{AH}$ em água Mili-Q, a turbidez final obtida foi de 45 NTU, e em água torneira foi de 33 NTU. Foi observado que a porém a presença do AH e dos cátions gera uma maior adsorção das partículas no pH 12 o que não foi observado em meio ácido. 


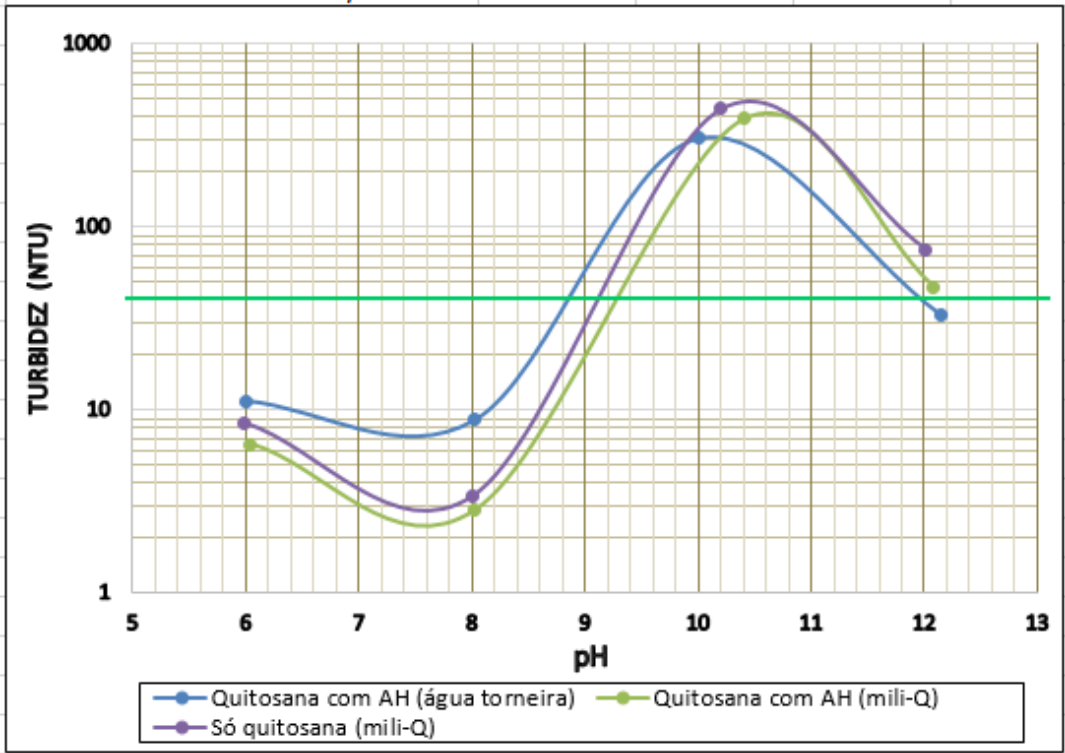

Figura 95 Floculação da lama vermelha (0.6\%), com quitosana $(1289 \mathrm{~g} / \mathrm{t}) \mathrm{e}$ $\mathrm{AH}(10 \mathrm{~g} / \mathrm{t})$, em água torneira, com quitosana (1289 g/t) e $\mathrm{AH}(10 \mathrm{~g} / \mathrm{t})$, em água Mili-Q.e só com quitosana (1289 g/t) em água Mili-Q, em 179 rpm, no jar test.

Na Figura 96, mostram-se as floculações a diferentes $\mathrm{pH}$ com os parâmetros otimizados, em água da torneira.
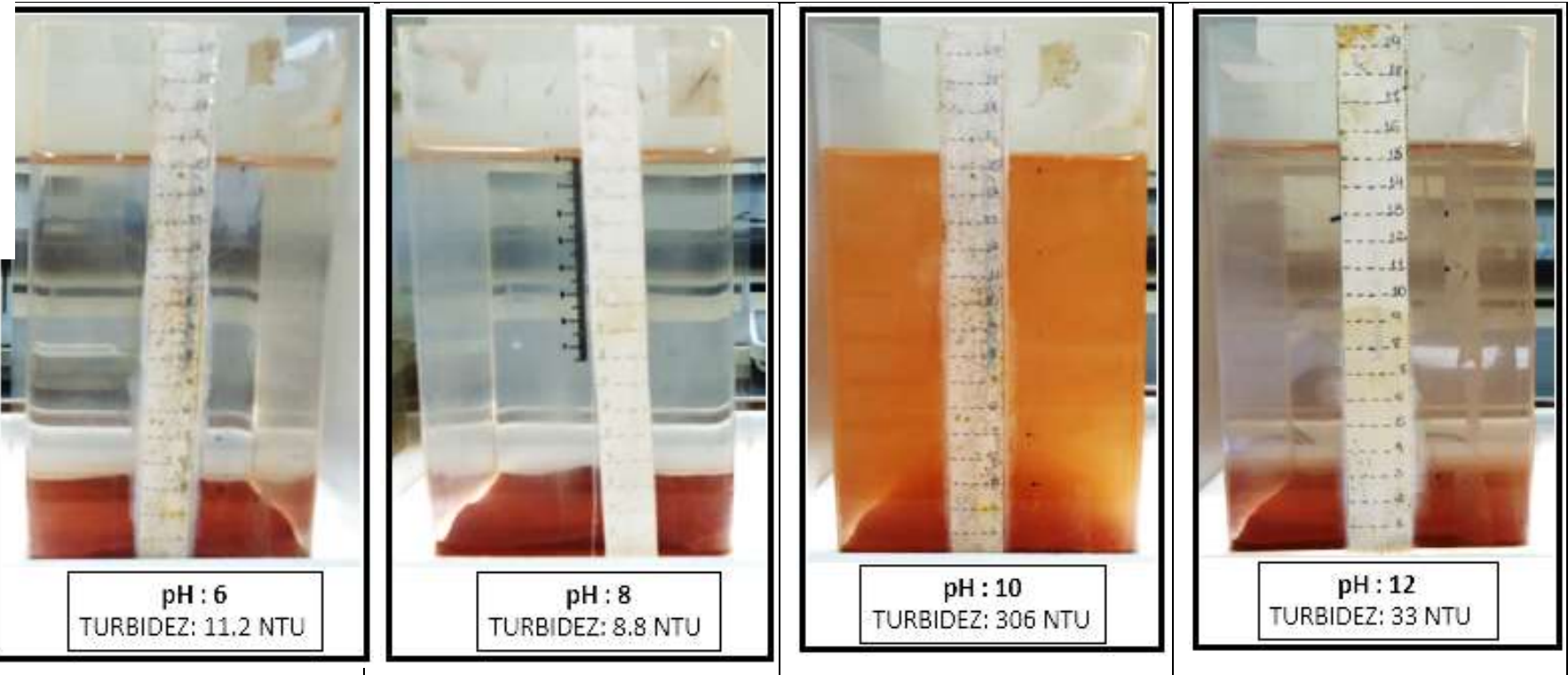

Figura 96 Floculações da lama vermelha, com quitosana (1289 g/t) e AH (10 g/t) em $\mathrm{pH}$ de 6, 8, 10 e 12, em 179 rpm, no jar test. 


\subsubsection{Floculação com diferentes ácidos húmicos (AH`s)}

Realizaram-se testes de floculação com os parâmetros optimizados (Tabela 26), em pH 12, com diferentes ácidos húmicos:

$>$ Ácido húmico extraído do carvão (produzido pela PUC-Rio).

$>$ Ácido húmico extraído do coque (produzido pela PUC-Rio).

> Ácido húmico extraído do río (comercializado pela IHSS).

> Ácido húmico standar pahokee (comercializado pela IHHS).

Como pode-se observar na Figura 97, o melhor resultado de floculação e redução da turbidez lama vermelha foi obtido com o ácido húmico extraído do coque, apresentando uma turbidez de 26,5 NTU. O ácido húmico extraído do carvão e do rio produziu um sobrenadante com turbidez de 29 NTU, e o ácido húmico padrão pahokee gerou sobrenadante com 34,4 NTU, e teve um comportamento bem parecido com o ácido húmico produzido pela Aldrich, cujo produto da floculação resultou em um sobrenadante com turbidez de 33 NTU.

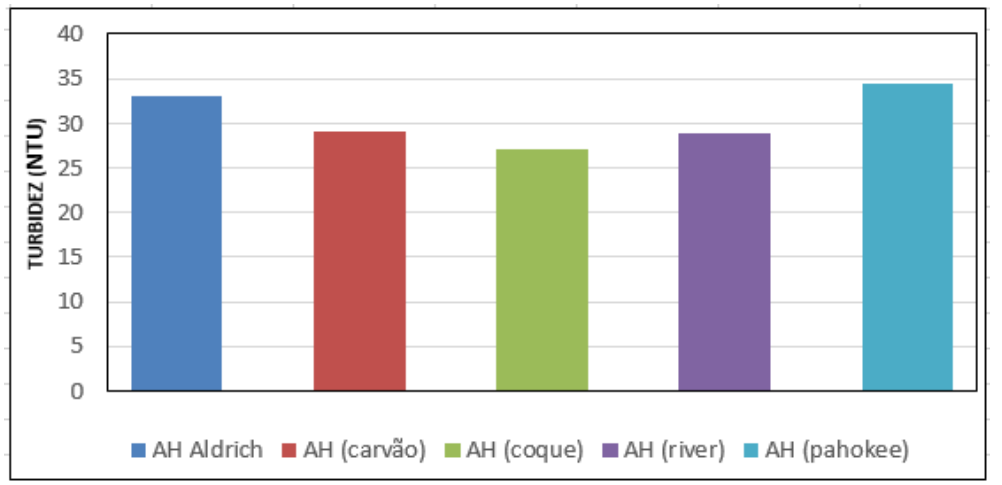

Figura 97 Floculação da lama vermelha (0.6\%), com quitosana (1289 g/t) e com diferentes ácidos húmicos de diferentes fontes (10 g/t), em pH 12, em 179 rpm, no jar test.

\subsubsection{Planejamento experimental da lama vermelha a pH 8}

Como vimos no item 6.6.11, nas floculações a diferentes pontos de $\mathrm{pH}$, observou-se que em o pH de 8 obteve-se a melhor turbidez. Porém, na Figura 98 mostra-se testes de floculação com porcentagens de sólidos maiores do que no planejamento experimental a pH 12. Como se pode observar obteve-se bons resultados de turbidez com $3 \%$ de sólidos de 9 NTU utilizando $20 \mathrm{~g} / \mathrm{t}$ de quitosana, na floculação realizada com $7 \%$ de sólidos utilizando $150 \mathrm{~g} / \mathrm{t}$ de quitosana em comparação com a floculação de $3 \%$ sólidos, obteve-se 31,8 NTU, manten-se 
dentro do parâmetro exigido pela CONAMA 357 (Silva, 2005), enquanto que para a floculação com $5 \%$ de sólidos com $85 \mathrm{~g} / \mathrm{t}$ de quitosana a resposta de turbidez de 59,2 NTU, não esteve dentro do parâmetro exigido pela CONAMA 357 (Silva, 2005).

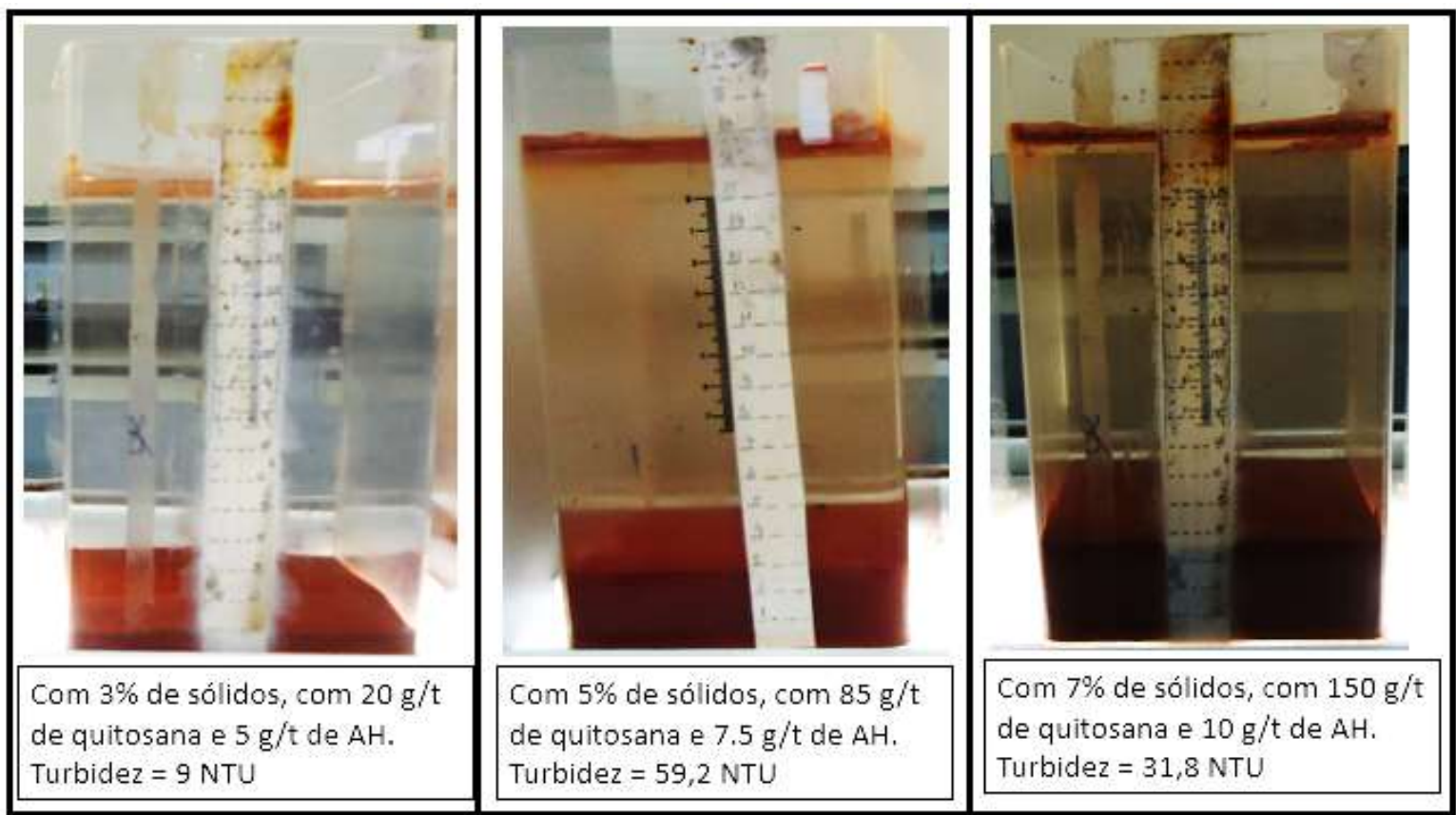

Figura 98 Floculação da lama vermelha, em pH 8, no jar test.

Baseado nesses pre-testes de floculação, realizou-se um planejamento experimental, mantendo as condições de velocidade de agitação e tempo de agitação constante para todos os testes, é dizer a $179 \mathrm{rpm}$ e $1.5 \mathrm{~min}$ respectivamente, (parâmetros optimizados do modelo Simplex).

$\mathrm{Na}$ Tabela 27, apresenta o planejamento experimental, considerando como variáveis de estudo: concentração de sólidos, dosagem de quitosana e ácido húmico.

Tabela 27 Fatores do planejamento experimental em pH 8.

\begin{tabular}{|l|c|c|c|c|}
\cline { 2 - 5 } \multicolumn{1}{c|}{} & Fator & - & + & $\mathbf{0}$ \\
\hline Concentração de sólidos (\%) & A & 3 & 7 & 5 \\
\hline Dosagem de quitosana (g/t) & B & 20 & 150 & 85 \\
\hline Dosagem de ácido húmico (g/t) & C & 5 & 10 & 7,5 \\
\hline
\end{tabular}

Os resultados da turbidez para cada teste do planejamento experimental da lama vermelha, em pH 8 é apresentado na Tabela 28, com 3 pontos centrais. 
Tabela 28 Planejamento experimental da lama vermelha em pH de 8.

\begin{tabular}{|c|c|c|c|c|}
\cline { 2 - 5 } \multicolumn{1}{c|}{} & $\begin{array}{c}\text { Conc. de } \\
\text { sólidos (\%) }\end{array}$ & $\begin{array}{c}\text { Quitosana } \\
\text { (g/t) }\end{array}$ & $\begin{array}{c}\text { AH } \\
\text { (g/t) }\end{array}$ & $\begin{array}{c}\text { Turbidez } \\
\text { (NTU) }\end{array}$ \\
\hline Teste & A & B & C & Y \\
\hline 1 & 3 & 20 & 5 & 22,9 \\
\hline 2 & 7 & 20 & 5 & 166,5 \\
\hline 3 & 3 & 20 & 5 & 9,0 \\
\hline 4 & 7 & 20 & 5 & 30,9 \\
\hline 5 & 3 & 150 & 10 & 20,5 \\
\hline 6 & 7 & 150 & 10 & 64,6 \\
\hline 7 & 3 & 150 & 10 & 14,2 \\
\hline 8 & 7 & 150 & 10 & 31,8 \\
\hline 9 & 5 & 85 & 7,5 & 58,4 \\
\hline 10 & 5 & 85 & 7,5 & 60,1 \\
\hline 11 & 5 & 85 & 7,5 & 59,2 \\
\hline
\end{tabular}

\subsubsection{Análise da variância com réplicas no ponto central do desenho}

a) Média dos testes (exceto pontos neutros):

$$
\bar{Y}=45 \mathrm{NTU}
$$

b) Média dos pontos centrais:

$$
\bar{y}=59,2 N T U
$$

Para o cálculo dos efeitos de cada tratamento se multiplica a transposta da matriz codificada (Tabela 4), pela matriz das respostas da variável dependente (turbidez). E para o cálculo da soma de quadrados dos efeitos de cada tratamento, se utiliza a Equação (21). Os resultados são apresentados na Tabela 48 (ANEXO 15).

Baseado nos cálculos realizados na Tabela 49 (ANEXO 16), a análise da variância se apresenta na Tabela 29, para a lama vermelha em testes realizados em $\mathrm{pH} 8$, que determina os efeitos independentes e interações significativas, segundo as tabelas de Fischer. 
Tabela 29 Análise da variância para lama vermelha em pH 8.

\begin{tabular}{|c|c|c|c|c|}
\hline Fator & SSxj & g.I & MSSxj & Fo \\
\hline $\bar{A}$ & 6453,9 & 1 & 6453,9 & 8922,4 \\
\hline$B$ & 4447,4 & 1 & 4447,4 & 6148,5 \\
\hline $\mathrm{C}$ & 1204,8 & 1 & 1204,8 & 1665,6 \\
\hline$A B$ & 2748,2 & 1 & 2748,2 & 3799,3 \\
\hline$A C$ & 1350,1 & 1 & 1350,1 & 1866,4 \\
\hline $\mathrm{BC}$ & 1521,5 & 1 & 1521,5 & 2103,4 \\
\hline $\mathrm{ABC}$ & 1132,3 & 1 & 1132,3 & 1565,4 \\
\hline Curvatura & 442,0 & 1 & 442,0 & 611,1 \\
\hline Erro & 1,4 & 2 & 0,72 & \\
\hline Total & 19301,5 & 10 & & \\
\hline
\end{tabular}

Uma variável ou interação é significativa se a seguinte relação é cumprida:

$$
\mathrm{Fo}>\mathrm{F}(\alpha \text { gl, gle })
$$

De tabelas de distribuição de Fisher, donde $\alpha=0.01, g l=1, g l e=2$, a um nível de significância do 99\%, o valor de $\mathrm{F}_{0.01}$ é 98.5 (Ver ANEXO 19)

Porém, pode observa-se na Tabela 29, que todas as variáveis são significativas além disso, existe um efeito de curvatura, por tanto o modelo linear não vai se ajustar aos parámetros das variáveis estabelecidas nos testes, por enquanto vai ter que se otimizar o modelo para segundo ordem, utilizando o desenho de composto central.

\subsubsection{Desenho composto central}

Como já foi mencionado no Item 4.2.8.2, para desenvolver o desenho composto central requer-se de novos valores para os testes do desenho composto central, fora dos pontos da faixa de parámetros estabelecidos no planejamento experimental inicial $\left(2^{\mathrm{k}}\right)$, a Tabela 50 (ANEXO 17), apresenta a matriz codificada para o novo requerimento de testes, para encontrar o modelo de segundo ordem.

A Tabela 30, apresenta os testes desenvolvidos do desenho composto central. Como se pode observar no teste 1, para a menor concentração de sólidos $1.6 \%$, se obteve a menor turbidez de 7,2 NTU, pode-se observar que no teste 2 , de maior porcentagem de sólidos, obteve-se uma turbidez de 145 NTU, tendo as mesmas condições de dosagens de quitosana e ácido húmico do que o teste 1 , o que reflete uma demanda por maior dosagem dos polímeros. No teste 3 houve também uma resposta alta de turbidez de 123 NTU, com a dosagem mínima de 
quitosana estabelecida pelo planejamento, mostrando uma demanda por maior dosagem de quitosana, comparando os testes 4 e 5, obteve-se uma resposta de turbidez bem parecida em valores, para uma mesma concentração de sólidos, utilizando quase o duplo em dosagens de $\mathrm{AH}$ e quitosana, mostrando que não adianta adicionar maior quantidade de quitosana para reduzir a turbidez.

Tabela 30 Desenho central composto em pH 8

\begin{tabular}{|c|c|c|c|c|}
\hline Teste & $\begin{array}{c}\text { Conc. sólidos } \\
\text { (\%) }\end{array}$ & $\begin{array}{c}\text { Quitosana } \\
\text { (g/t) }\end{array}$ & $\begin{array}{c}\text { AH } \\
\text { (g/t) }\end{array}$ & $\begin{array}{c}\text { Turbidez } \\
\text { (NTU) }\end{array}$ \\
\hline $\mathbf{1}$ & 1,6 & 85 & 7,5 & 7,2 \\
\hline $\mathbf{2}$ & 8,4 & 85 & 7,5 & 145 \\
\hline $\mathbf{3}$ & 5 & 24,2 & 7,5 & 123 \\
\hline $\mathbf{4}$ & 5 & 194,2 & 7,5 & 27,7 \\
\hline $\mathbf{5}$ & 5 & 85 & 3,3 & 29,4 \\
\hline $\mathbf{6}$ & 5 & 85 & 11,7 & 32,8 \\
\hline
\end{tabular}

Utilizando o programa estatístico "STATGRAPHICS CENTURION 16.0", se determinou as seguintes análises estatísticos:

\subsubsection{Análise de variância para o desenho composto central}

$\mathrm{Na}$ Tabela 31, é apresentada a análise de variância do desenho composto central, com um nível de significância do $95 \%$, onde se pode observar, que a concentração de sólidos e a presença de quitosana, são variáveis significativas, e as interações significativas foram: $A B$ e $C^{2}$, com um coeficiente de correlação do $91.3 \%$, o que refleta que o modelo se ajusta para um modelo de segundo ordem (Tabela 32).

Tabela 31 Análise de variância do desenho composto central em pH 8

\begin{tabular}{|l|c|c|c|c|c|}
\hline \multicolumn{1}{|c|}{ Fator } & Soma de quadrados & gl & Quadrado médio & razão-F & Valor-P \\
\hline A:Conc. sólidos & 15423,5 & 1 & 15423,5 & 38,85 & 0,0003 \\
\hline B:quitosana & 8912,28 & 1 & 8912,28 & 22,450 & 0,0015 \\
\hline C:AH & 626,27 & 1 & 626,27 & 1,580 & 0,2446 \\
\hline AA:Conc. Sólidos*Conc. Sólidos & 39,71 & 1 & 39,71 & 0,100 & 0,7599 \\
\hline AB:Conc. Sólidos ${ }^{*}$ quitosana & 2745,40 & 1 & 2745,40 & 6,910 & 0,0302 \\
\hline AC:Conc. Sólidos*AH & 1346,80 & 1 & 1346,80 & 3,390 & 0,1028 \\
\hline BC:quitosana:AH & 1523,52 & 1 & 1523,52 & 3,840 & 0,0858 \\
\hline CC:AH*AH & 2461,40 & 1 & 2461,40 & 6,200 & 0,0375 \\
\hline Error total & 3176,34 & 8 & 397,04 & & \\
\hline Total (corr.) & 36542,80 & 16 & & & \\
\hline
\end{tabular}


Tabela 32 Coeficiente de correlação do modelo de segundo ordem

\begin{tabular}{|l|c|}
\hline R-quadrada = & $91,30 \%$ \\
\hline R-quadrado (ajustado para g.I.) = & $82,60 \%$ \\
\hline Erro padrão do est. = & 19,9 \\
\hline Erro absoluto medio = & 11 \\
\hline Estatístico Durbin-Watson = & 1,8 \\
\hline
\end{tabular}

\subsubsection{Modelo matemático}

O modelo matemático de segundo ordem, obtido do programa estatístico "STATGRAPHICS CENTURION 16.0 é apresentado na Equação (27):

Turbidez $=63+33,6 A-25,5 B-18,5 A B-14,1 C^{2}$

\subsubsection{Diagrama de Pareto}

No diagrama de Pareto (Figura 99), observamos como influencia principal sobre a turbidez as seguintes variáveis: A (concentração de sólidos), que apresenta um efeito positivo, quer dizer que ao aumentar seu efeito aumenta 0 resultado da turbidez, B (dosagem de quitosana), apresenta um efeito negativo, quer dizer que é inversamente proporcional com a resposta de turbidez. E como interações entre as variáveis se apresenta: $A B$ (concentração de sólidosquitosana), e a interação quadrática CC (ácido húmico-ácido humico), apresentam um efeito negativo, quer dizer que indicam, a necessidade da diminuição do efeito conjunto de seus fatores para diminuir o resultado da turbidez.

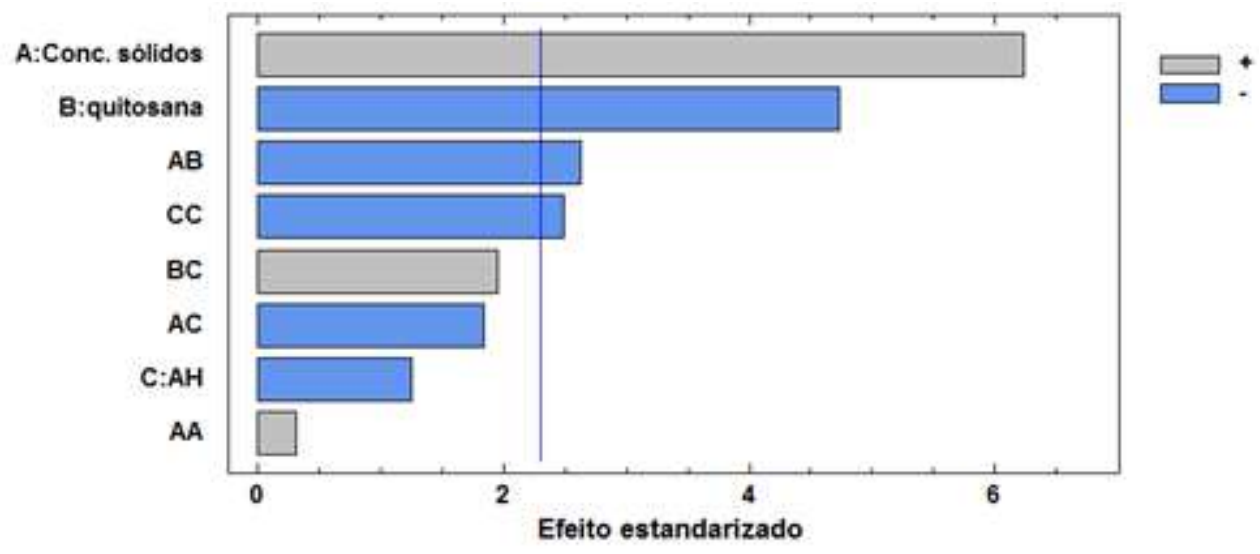

Figura 99 Diagrama de Pareto a pH 8 
Na Figura 100, apresenta-se os efeitos principais da turbidez, com relação à concentração de sólidos, têm uma relação diretamente proporcional com a turbidez, quanto maior a concentração de sólidos maior será a turbidez com relação à presença da quitosana nota-se um efeito negativo, mostrando uma relação inversamente proporcional, ou seja quanto maior a dosagem de quitosana menor será o valor de turbidez. Esses resultados são ratificados pelo diagrama de Pareto (Figura 99). Com relação ao ácido húmico observa-se um efeito curvo, com inclinação negativa a partir de um valor médio, significando que a partir desse valor, apresenta uma relação inversamente proporcional à resposta de turbidez.

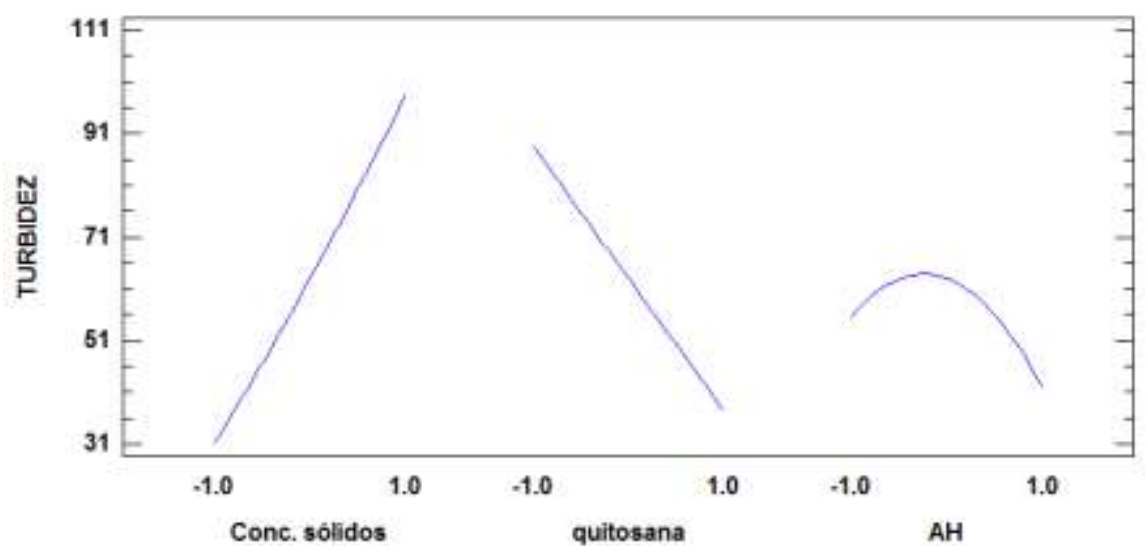

Figura 100 Efeito principais das variáveis em pH 8.

\subsubsection{Diagrama de contorno de superficie}

A Figura 101, apresenta a predição para diferentes respostas de turbidez, com valor meio do $\mathrm{AH}$, e tem um efeito notório, que para flocular maior quantidade de sólidos, maior será a quantidade de quitosana utilizada. Em floculações para $3 \%$ de sólidos, para atingir uma turbidez menor do que 40 NTU, exige um valor na dosagem da quitosana a partir do ponto médio, para as floculações de $5 \%$ exige o valor alto do planejamento e para valores acima de 7\% de sólidos exige um valor acima do valor maior do planejamento na dosagem da quitosana. 


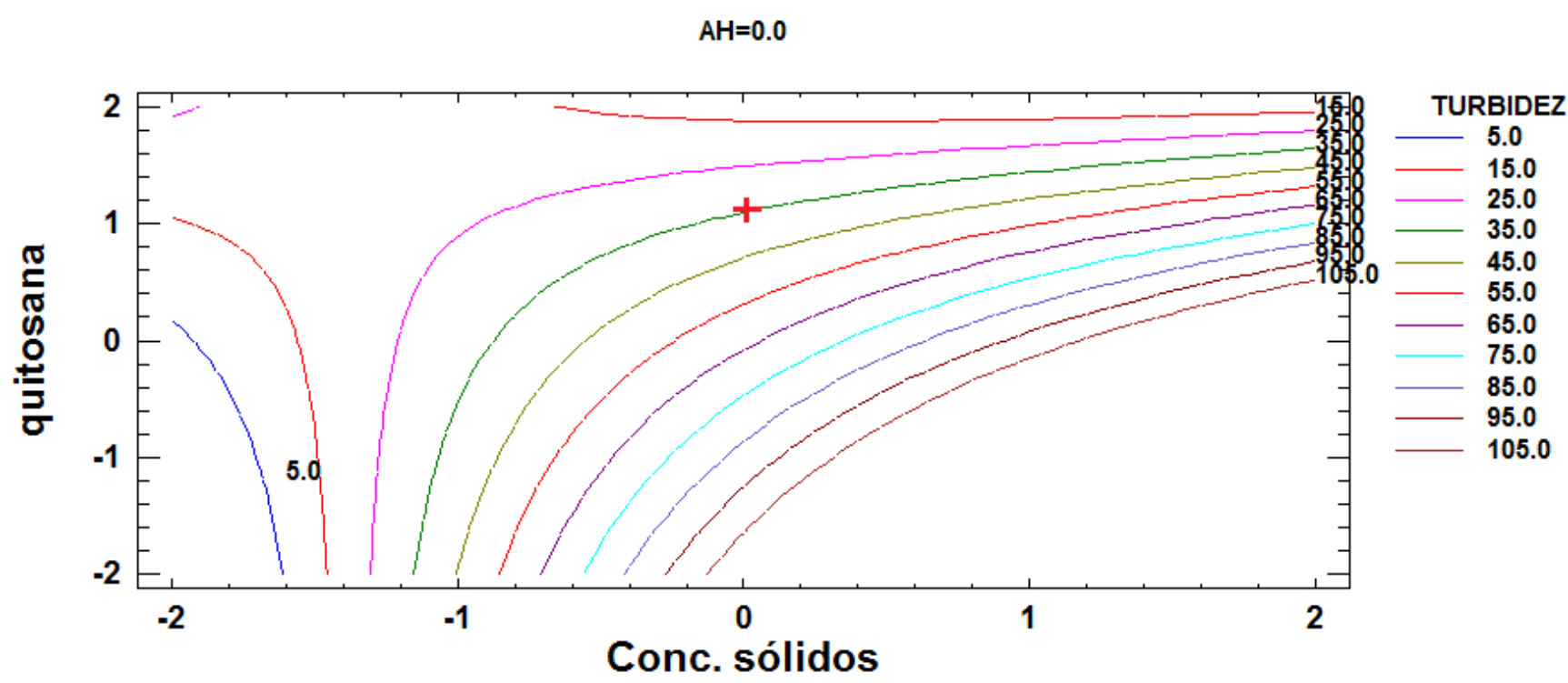

Figura 101 Contornos da superfície estimada da floculação em pH 8.

\subsubsection{Otimização de parâmetros}

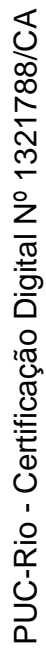

Mediante o software estatístico "Statgraphics Centurion 16.0", se minimizou a turbidez para 35 NTU, como se observa na Tabela 51 (ANEXO 18), e os parâmetros ótimos calculados para uma turbidez de 35 NTU são apresentados na Tabela 33:

Tabela 33 Parâmetros optimizados para 35 NTU em pH 8

\begin{tabular}{|c|c|}
\hline Variável & Parâmetro \\
\hline Conc. sólidos & $5,0 \%$ \\
\hline Quitosana & $156,5 \mathrm{~g} / \mathrm{t}$ \\
\hline AH & $7,5 \mathrm{~g} / \mathrm{t}$ \\
\hline
\end{tabular}

Este ajuste do modelo de segundo ordem, faz refletir que para atingir a floculação a 35 NTU, para o valor central de concentração de sólidos, a dosagem de quitosana esteve deficiente na floculação, e a dosagen do AH manteve-se no valor do ponto central. 


\section{7 \\ Conclusões}

As floculações com a presença da quitosana com $\mathrm{AH}$, foram efetivas no $\mathrm{pH}$ 7 no caso do rejeito de $\mathrm{Ni}$, e em $\mathrm{pH} 8$ no caso da lama vermelha, caracterizando uma separação dos sólidos contidos em polpas mineriais de interesse ambiental, uma vez que tratam-se de polímeros biodegradáveis.

A adsorção de quitosana junto com o AH nas partículas, são eficientes na faixa ácida a neutra, entretanto a adsorção da quitosana foi mais eficiente do que do $\mathrm{AH}$, isto se deve, possivelmente, às diferenças das suas massas molares, 232 kDa da quitosana e 25,1 kDa do $\mathrm{AH}$.

O caráter zwitterion do $\mathrm{AH}$ (ação de tamponamento), permitiu que pequenas quantidades de $\mathrm{H}^{+}$adicionado fossem adsorvidas pelos grupos negativos carboxilatos e fenólicos, enquanto que pequenas quantidades de íons $\mathrm{OH}^{-}$fossem adsorvidos pela carga positiva dos íons $\mathrm{NH}^{3+}$, presentes no $\mathrm{AH}$.

$\mathrm{A}$ adsorção da quitosana junto com o $\mathrm{AH}$ nas partículas de rejeito de $\mathrm{Ni}$ foi mais eficiente na faixa ácida, tanto com o $\mathrm{AH}$ (Aldrich), quanto com os outros $\mathrm{AH}$ 's testados comparativamente. Resultados de maior eficiência de floculação foram, ainda, observados quando a polpa foi preparada com água de torneira, o que promoveu, provavelmente, a eficiência de adsorção, com pontes de ligação dos cátions presentes na água.

A adsorção da quitosana junto com o $\mathrm{AH}$ nas partículas de lama vermelha foi mais eficiente na floculação em $\mathrm{pH} 8$ do que em $\mathrm{pH} 12$; isto é devido à protonação dos grupos fenólicos ( $\mathrm{pKa}=8,59)$ e os íons da água da torneira influenciaram com pontes de ligação na adsorção polímero-partícula em pH 12, enquanto que no $\mathrm{pH} 8$, a adsorção polímero-partícula ocorre por troca iônica entre esses componentes do sistema.

No modelo matemático obtido para o rejeito de $\mathrm{Ni}$, a quitosana tem um forte efeito na redução da turbidez, a velocidade de agitação e o tempo de agitação são 
variáveis que devem ser mantidas com valores reduzidos, pois têm influencia na quebra de flocos, sendo maior a quebra dos flocos formados com o $\mathrm{AH}$ do que com a quitosana, como o reflete a interação CD do modelo.

Turbidez $=61,4-14,9 B+9,8 D+6,4 E-5,7 A^{2}-3,8 D^{2}-2,8 C D-3,7 D E$

Para a lama vermelha, em pH 12, o modelo matemático obtido apresenta a concentração de sólidos, a velocidade e tempo de agitação têm uma forte influência no aumento da turbidez. A quitosana tem o efeito de redução da turbidez, enquanto que a dosagem de ácido húmico, conjugada com o tempo de agitação, apresentam um efeito sinérgico no aumento da turbidez.

$$
\begin{gathered}
\text { Turbidez }=55,8+12,8 A-17,2 B+6,6 D+3,2 E+4,2 A D+5,9 A E+6,4 B E \\
+1,9 C E
\end{gathered}
$$

Para o modelo matemático obtido para a lama vermelha em $\mathrm{pH} 8$, a concentração de sólidos tem uma forte influência no aumento da turbidez; a quitosana tem o efeito de redução da turbidez e o efeito quadrático da dosagem de ácido húmico indica a necessidade da diminuição do efeito conjunto de seus fatores para diminuir o resultado da turbidez.

$$
\text { Turbidez }=63+33,6 A-25,5 B-18,5 A B-14,1 C^{2}
$$

Na otimização dos parâmetros para a floculação do rejeito de $\mathrm{Ni}$, conseguiuse maximar a concentração de sólidos até até $2,2 \%$, ao mesmo tempo em que foram minimizadas as dosagens de quitosana até $24,9 \mathrm{~g} / \mathrm{t}$ e do $\mathrm{AH}$ de 6,3 g/t. A velocidade de agitação foi reduzida a 119 rpm (menor do que o parâmetro estabelecido no planejamento) e o tempo de agitação foi de 1 min $41 \mathrm{~s}$.

$\mathrm{Na}$ otimização dos parâmetros para a floculação com a lama vermelha, em $\mathrm{pH}$ de 12 , conseguiu-se maximar até $0,6 \%$ de sólidos, mantendo a dosagem de quitosana de $1289 \mathrm{~g} / \mathrm{t}$ e do $\mathrm{AH}$ de $10 \mathrm{~g} / \mathrm{t}$. Em pH 8, conseguiu-se maximar até $5 \%$ de sólidos com dosagensm de 156,5 g/t da quitosana e 7,5 g/t de $\mathrm{AH}$. Porém a melhor condição operacional para a realização da floculação é em pH 8, devido aos menores custos envolvidos no uso dos polímeros. Além de possibilitar o tratamento de uma polpa com maior concentração de sólidos, propicia a geração de um efluente líquido apropriado para descarte ou reuso industrial, contribuindo para a sustentabilidade do processo. 
8

Recomendações e sugestões

> Testar com ácidos fúlvicos e com concentrações altas de eletrólitos (>1M), porque apresenta maior sítios disponíveis do que o ácido húmico.

> Avaliar a eficiencia de floculação com maior quantidade de eletrolito presente na polpa.

> Avaliar a interação só do ácido húmico em polpas minerais, em faixas ácidas.

- Aplicar os modelos matemáticos a uma escala piloto.

$>$ Comparar os valores optimizados de cada modelo matemático, em escala piloto. 
9

\section{Refêrencias Bibliográficas}

ALVES SAMPAIO, J.; ALVES FRANÇA, S.; ALMEIDA BRAGA, P. TRATAMENTO DE MINÉRIOS: PRÁTICAS LABORATORIAIS. Rio de Janeiro: [s.n.], 2007.

AMRAM, K.; GANOR, J. The combined effect of $\mathrm{pH}$ and temperature on smectite dissolution rate under acidic conditions. Geochimica et Cosmochimica Acta, v. 69, n. 10, p. 2535-2546, maio 2005.

ANDRADE, T. Avaliação sobre o potencial de extração de ácidos húmicos a partir de diferentes precursores carbonáceos. [s.I.] Pontifica Católica do Rio de Janeiro, 2014.

ARAÚJO, W.; FASCIO, M. Esquema para interpretação de espectros de substâncias orgânicas na região do infravermelho. p. 4, 2004.

AYRES, H.; TORRES, F.; PONCE, M. Diseños Experimentales Su Aplicación en Ingeniería de Procesos. 2000.

BEDDIN, M. Adsorção de $\mathrm{Cr}(\mathrm{VI})$ na interface água-minerais sedimentários. Efeito das condições de reação e modelo de adsorção. Disponível em: $<$ https://repositorio.ufsc.br/bitstream/handle/123456789/83928/182720.pdf ?sequence=1>. Acesso em: 15 fev. 2016.

BOHUSLAV, D. Coagulation and Flocculation. New York: [s.n.], 1993.

BOLTO, B.; GREGORY, J. Organic polyelectrolytes in water treatment. Water Research, v. 41, p. 2301-2324, 2007.

BRATSKAYA, S.; SCHWARZ, S.; CHERVONETSKY, D. Comparative study of humic acids flocculation with chitosan hydrochloride and chitosan glutamate. Water Research, v. 38, p. 2955-2961, 2004.

CHANG, M. Y.; JUANG, R. S. Adsorption of tannic acid, humic acid, and dyes from water using the composite of chitosan and activated clay. Journal of Colloid and Interface Science, v. 278, p. 18-25, 2004.

DIVAKARAN, R.; PILLAI, V. N. S. Mechanism of kaolinite and titanium dioxide flocculation using chitosan - Assistance by fulvic acids? Water Research, v. 38, p. 2135-2143, 2004. 
GARCES, K. Extração de ácido húmico a partir de carvão mineral e sua aplicação na remoção de chumbo e cadmio de soluções aquosas. [s.l.] Pontifica Católica do Rio de Janeiro, 2015.

GUTIÉRREZ, H.; LA VARA, R. DE. ANÁLISIS Y DISEÑO DE EXPERIMENTOS. [s.I: s.n.], 2008.

HIEMENZ, P. C.; RAJAGOPALAN, R. Principles of Colloid and Surface Chemistry. Third edit ed.Florida: [s.n.], 1997.

HOLMBERG, K. et al. Surfactants and Polymers in Aqueous Solution. 2nd Editio ed.[s.l: s.n.], 2002.

HUNTER, R. J. Introduction to modern colloid science. New York: [s.n.], 1993.

IHSS. Natural Organic Matter Research. Disponível em: $<$ http://www.humicsubstances.org/sources.html>, 2016.

KELLEY, K. R.; STEVENSON, F. J. Humic Substances in Terrestrial Ecosystems. [s.I.] Elsevier, 1996.

KIM, E. K.; WALKER, H. W. Effect of cationic polymer additives on the adsorption of humic acid onto iron oxide particles. Colloids and Surfaces A: Physicochemical and Engineering Aspects, v. 194, p. 123-131, 2001.

KOMADEL, P.; MADEJOVÁ, J. Handbook of Clay Science. [s.I.] Elsevier, 2006. v. 1

LI, J. et al. Optimizing coagulation and flocculation process for kaolinite suspension with chitosan. Colloids and Surfaces A: Physicochemical and Engineering Aspects, v. 428, p. 100-110, 2013.

LIU, Y.; NAIDU, R.; MING, H. Surface electrochemical properties of red mud (bauxite residue): zeta potential and surface charge density. Journal of colloid and interface science, v. 394, p. 451-7, 15 mar. 2013.

MAHMOUD, A. et al. Electrical field: a historical review of its application and contributions in wastewater sludge dewatering. Water research, v. 44, n. 8 , p. 2381-407, abr. 2010.

MALVERN, I. Zeta potential An introduction in 30 minutes. [s.I: s.n.]. Disponível em: <http://www3.nd.edu/ rroeder/ame60647/slides/zeta.pdf>, 2011.

MURPHY, E. M. et al. Interaction of hydrophobic organic compounds with mineral-bound humic substances. Environmental science \& technology, v. 28, n. 7, p. 1291-9, 1 jul. 1994.

PAIVA, D. et al. Introdução à espectroscopia. [s.I: s.n.], 2010. 
PALACIOS, S. ESTADÍSTICA EXPERIMENTAL Aplicada a ciencia e ingeniería. Lima Peru: [s.n.], 2013.

PASSOS, R. Apostila: Qualidade da água. Disponível em: $<$ https://pt.scribd.com/doc/36588425/Apostila-Qualidade-da-Agua>, 2010.

PEREIRA, A.; PEREIRA, C. Anais SEIC-UFOP. Disponível em: $<$ http://www.seic.ufop.br/anais/exibir_trabalho/3590>. Acesso em: $15 \mathrm{fev}$. 2016.

QUEMENEUR, F.; RINAUDO, M.; PÉPIN-DONAT, B. Influence of Molecular Weight and pH on Adsorption of Chitosan at the Surface of Large and Giant Vesicles Influence of Molecular Weight and pH on Adsorption of Chitosan at the Surface of Large and Giant Vesicles. p. 396-402, 2008.

RINAUDO, M. Chitin and chitosan: Properties and applications. Progress in Polymer Science, v. 31, p. 603-632, 2006.

SHAW, D. J. INTRODUÇÃO À QUÍMICA DOS COLOIDES E DE SUPERFÍCIES. Edgard Blu ed.São Paulo: [s.n.], 1975.

SIGMA-ALDRICH. No Title. Disponível em: $<$ http://www.sigmaaldrich.com/catalog/product/aldrich/h16752?lang=pt\&re gion=BR\&cm_sp=Insite-_-prodRecCold_xviews-_-prodRecCold10-1>, 2016.

SILVA, M. Resolução Nro. 357, de 17 de março de 2005. p. 27, 2005.

SOARES, V. DISPERSÃO E ESTABILIZAÇÃO DE PARTÍCULAS SUBMICROMÉTRICAS DE ÓXIDO DE ALUMIINIO EM SISTEMAS LÍQUIDOS DESTINADOS À PRODUÇÃO DE MATERIAIS REFRATÁRIOS. [s.I.] Universidade Federal de Minas Gerais, 2009.

STEVENSON, F. J. Humus Chemistry. second edi ed.New York: John Wiley\&Sons, Inc, 1994.

SUÁREZ, M. Modificação do resíduo de bauxita gerado no processo Bayer por tratamento térmico. [s.I.] Escola Politécnica da Universidade de Sao Paulo, 2012.

TAÍS, F.; NITO, D. Determinação do potencial zeta da pirita sob o efeito de agentes modificadores de superfície. Disponível em: <https://sec.sbq.org.br/cdrom/30ra/resumos/T1139-1.pdf>. Acesso em: 15 fev. 2016.

THENG, B. K. G. Formation and Properties of Clay-Polymer Complexes. Volume 4 ed.[s.I: s.n.], 2012. 
VERMEER, A. W. P.; RIEMSDIJK, W. H. VAN; KOOPAL, L. K. Adsorption of Humic Acid to Mineral Particles. 1. Specific and Electrostatic Interactions. Langmuir, v. 14, n. 10, p. 2810-2819, maio 1998.

WANG, C. et al. Current state of fine mineral tailings treatment: A critical review on theory and practice. Minerals Engineering, v. 58, p. 113-131, abr. 2014.

WOLFGANG, P. Aglomeration in industry. Weinheim: [s.n.], 2005.

YAN, L. et al. Determination of anisotropic surface characteristics of different phyllosilicates by direct force measurements. Langmuir : the ACS journal of surfaces and colloids, v. 27, n. 21, p. 12996-3007, 1 nov. 2011.

YAN, W. L.; BAI, R. Adsorption of lead and humic acid on chitosan hydrogel beads. Water Research, v. 39, p. 688-698, 2005.

YUEHUA, $\mathrm{H}$. et al. Role of macromolecules in kaolinite flotation. Minerals Engineering, v. 17, n. 9-10, p. 1017-1022, set. 2004.

ZETA-METER, I. Potencial Zeta. Disponível em: $<$ http://depa.fquim.unam.mx/amyd/archivero/PotencialZeta_1246.pdf>, 2012.

ZHANG, X.; BAI, R. Mechanisms and kinetics of humic acid adsorption onto chitosan-coated granules. Journal of Colloid and Interface Science, v. 264, p. 30-38, 2003.

ZHOU, Y. et al. Comparative study on the adsorption interactions of humic acid onto natural magnetite, hematite and quartz: Effect of initial HA concentration. Powder Technology, v. 251, p. 1-8, 2014.

ZOUBOULIS, A. I.; JUN, W.; KATSOYIANNIS, I. Removal of humic acids by flotation. Colloids and Surfaces A: Physicochemical and Engineering Aspects, v. 231, p. 181-193, 2003. 
10

Anexos

\section{ANEXO 1}

Tabela 34 Avaliação estadística dos íons da água da torneira

\begin{tabular}{|c|c|c|c|c|c|c|}
\hline \multicolumn{2}{|c|}{ Composto } & \multirow{2}{*}{\begin{tabular}{|c|} 
amostra (mg/l) \\
$x$ \\
\end{tabular}} & \multirow[b]{2}{*}{ xprom. } & \multirow[b]{2}{*}{$(x-\text { xprom })^{\wedge} 2$} & \multirow[b]{2}{*}{ s (desv. Estándar) } & \multirow[b]{2}{*}{ significancia ao $95 \%$} \\
\hline $\mathrm{Cl}-$ & nro. amostra & & & & & \\
\hline & 1 & 5.3 & 5.71 & 0.17016 & 0.181 & se rejeita \\
\hline & 2 & 5.7 & 5.71 & 0.00016 & & se aceita \\
\hline & 3 & 5.7 & 5.71 & 0.00016 & t 0.05 & se aceita \\
\hline & 4 & 5.8 & 5.71 & 0.00766 & 2.92 & se aceita \\
\hline & 5 & 5.9 & 5.71 & 0.03516 & nivel min. & se rejeita \\
\hline & 6 & 5.7 & 5.71 & 0.00016 & 5.53 & se aceita \\
\hline & 7 & 5.8 & 5.71 & 0.00766 & nivel max. & se aceita \\
\hline & 8 & 5.8 & 5.71 & 0.00766 & 5.89 & se aceita \\
\hline & & & sumatoria & 0.23 & promedio & $5.75 \mathrm{mg} / \mathrm{l}$ \\
\hline \multirow[t]{10}{*}{ SO4-2 } & nro. amostra & $(\mathrm{mg} / \mathrm{l})$ & xprom. & $(x \text {-xprom })^{\wedge} 2$ & s (desv. Estándar) & significancia ao $95 \%$ \\
\hline & 1 & 6.7 & 6.35 & 0.1225 & 0.283 & se rejeita \\
\hline & 2 & 6.5 & 6.35 & 0.0225 & & se aceita \\
\hline & 3 & 6.1 & 6.35 & 0.0625 & t 0.05 & se aceita \\
\hline & 4 & 6.1 & 6.35 & 0.0625 & 2.92 & se aceita \\
\hline & 5 & 6.8 & 6.35 & 0.2025 & nivel min. & se rejeita \\
\hline & 6 & 6.3 & 6.35 & 0.0025 & 6.07 & se aceita \\
\hline & 7 & 6.2 & 6.35 & 0.0225 & nivel max. & se aceita \\
\hline & 8 & 6.1 & 6.35 & 0.0625 & 6.63 & se aceita \\
\hline & & & sumatoria & 0.56 & promedio & $6.22 \mathrm{mg} / \mathrm{l}$ \\
\hline \multirow[t]{10}{*}{ NO3- } & nro. amostra & $(\mathrm{mg} / \mathrm{l})$ & xprom. & $(x \text {-xprom })^{\wedge} 2$ & s (desv. Estándar) & significancia ao $95 \%$ \\
\hline & 1 & 1.3 & 1.05125 & 0.0619 & 0.224 & se aceita \\
\hline & 2 & 1.2 & 1.05125 & 0.0221 & & se aceita \\
\hline & 3 & 0.73 & 1.05125 & 0.1032 & t 0.05 & se rejeita \\
\hline & 4 & 1.1 & 1.05125 & 0.0024 & 2.92 & se aceita \\
\hline & 5 & 1.2 & 1.05125 & 0.0221 & nivel min. & se aceita \\
\hline & 6 & 0.72 & 1.05125 & 0.1097 & 0.83 & se rejeita \\
\hline & 7 & 0.96 & 1.05125 & 0.0083 & nivel max. & se aceita \\
\hline & 8 & 1.2 & 1.05125 & 0.0221 & 1.27 & se aceita \\
\hline & & & sumatoria & 0.35 & promedio & $1.01 \mathrm{mg} / \mathrm{l}$ \\
\hline \multirow[t]{10}{*}{ Al } & nro. amostra & $(\mathrm{mg} / \mathrm{l})$ & xprom. & (x-xprom)^2 & s (desv. Estándar) & significancia ao $95 \%$ \\
\hline & 1 & 0.22 & 0.18375 & 0.00131 & 0.044 & se aceita \\
\hline & 2 & 0.19 & 0.18375 & 0.00004 & & se aceita \\
\hline & 3 & 0.18 & 0.18375 & 0.00001 & t 0.05 & se aceita \\
\hline & 4 & 0.17 & 0.18375 & 0.00019 & 2.92 & se aceita \\
\hline & 5 & 0.26 & 0.18375 & 0.00581 & nivel min. & se rejeita \\
\hline & 6 & 0.19 & 0.18375 & 0.00004 & 0.14 & se aceita \\
\hline & 7 & 0.12 & 0.18375 & 0.00406 & nivel max. & se rejeita \\
\hline & 8 & 0.14 & 0.18375 & 0.00191 & 0.23 & se aceita \\
\hline & & & sumatoria & 0.01 & promedio & $0.17 \mathrm{mg} / \mathrm{l}$ \\
\hline \multirow[t]{10}{*}{$\mathrm{Ca}$} & nro. amostra & $(\mathrm{mg} / \mathrm{l})$ & xprom. & $(x \text {-xprom })^{\wedge} 2$ & s (desv. Estándar) & significancia ao $95 \%$ \\
\hline & 1 & 5.7 & 5.525 & 0.0306 & 0.276 & se aceita \\
\hline & 2 & 5.7 & 5.525 & 0.0306 & & se aceita \\
\hline & 3 & 5.3 & 5.525 & 0.0506 & t 0.05 & se aceita \\
\hline & 4 & 5.3 & 5.525 & 0.0506 & 2.92 & se aceita \\
\hline & 5 & 5.8 & 5.525 & 0.0756 & nivel min. & se aceita \\
\hline & 6 & 5.9 & 5.525 & 0.1406 & 5.26 & se rejeita \\
\hline & 7 & 5.3 & 5.525 & 0.0506 & nivel max. & se aceita \\
\hline & 8 & 5.2 & 5.525 & 0.1056 & 5.79 & se rejeita \\
\hline & & & sumatoria & 0.54 & promedio & $5.4 \mathrm{mg} / \mathrm{l}$ \\
\hline
\end{tabular}




\begin{tabular}{|c|c|c|c|c|c|c|}
\hline $\mathrm{Fe}$ & nro. amostra & $(\mathrm{mg} / \mathrm{l})$ & xprom. & $(x-\text { xprom })^{\wedge} 2$ & s (desv. Estándar) & significancia ao $95 \%$ \\
\hline & 1 & 0.29 & 0.2625 & 0.00076 & 0.030 & se aceita \\
\hline & 2 & 0.28 & 0.2625 & 0.00031 & & se aceita \\
\hline & 3 & 0.21 & 0.2625 & 0.00276 & t 0.05 & se rejeita \\
\hline & 4 & 0.26 & 0.2625 & 0.00001 & 2.92 & se aceita \\
\hline & 5 & 0.3 & 0.2625 & 0.00141 & nivel min. & se rejeita \\
\hline & 6 & 0.26 & 0.2625 & 0.00001 & 0.23 & se aceita \\
\hline & 7 & 0.23 & 0.2625 & 0.00106 & nivel max. & se aceita \\
\hline & 8 & 0.27 & 0.2625 & 0.00006 & 0.29 & se aceita \\
\hline & & & sumatoria & 0.01 & promedio & $0.27 \mathrm{mg} / \mathrm{l}$ \\
\hline \multirow[t]{10}{*}{$\mathrm{Mg}$} & nro. amostra & $(\mathrm{mg} / \mathrm{l})$ & \begin{tabular}{|l|} 
xprom. \\
\end{tabular} & $($ x-xprom)^2 & s (desv. Estándar) & significancia ao $95 \%$ \\
\hline & 1 & 1.20 & 1.2125 & 0.00016 & 0.064 & se aceita \\
\hline & 2 & 1.30 & 1.2125 & 0.00766 & & se aceita \\
\hline & 3 & 1.10 & 1.2125 & 0.01266 & t 0.05 & se rejeita \\
\hline & 4 & 1.20 & 1.2125 & 0.00016 & 2.92 & se aceita \\
\hline & 5 & 1.30 & 1.2125 & 0.00766 & nivel min. & se aceita \\
\hline & 6 & 1.20 & 1.2125 & 0.00016 & 1.2 & se aceita \\
\hline & 7 & 1.20 & 1.2125 & 0.00016 & nivel max. & se aceita \\
\hline & 8 & 1.20 & 1.2125 & 0.00016 & 1.3 & se aceita \\
\hline & & & sumatoria & 0.03 & promedio & $1.2 \mathrm{mg} / \mathrm{l}$ \\
\hline \multirow[t]{10}{*}{ K } & nro. amostra & $(\mathrm{mg} / \mathrm{l})$ & xprom. & $(\text { x-xprom })^{\wedge} 2$ & s (desv. Estándar) & significancia ao $95 \%$ \\
\hline & 1 & 2.6 & 2.5 & 0.010 & 0.245 & se aceita \\
\hline & 2 & 2.5 & 2.5 & 0.000 & & se aceita \\
\hline & 3 & 2.7 & 2.5 & 0.040 & t 0.05 & se aceita \\
\hline & 4 & 2 & 2.5 & 0.250 & 2.92 & se rejeita \\
\hline & 5 & 2.7 & 2.5 & 0.040 & nivel min. & se aceita \\
\hline & 6 & 2.5 & 2.5 & 0.000 & 2.3 & se aceita \\
\hline & 7 & 2.7 & 2.5 & 0.040 & nivel max. & se aceita \\
\hline & 8 & 2.3 & 2.5 & 0.040 & 2.7 & se aceita \\
\hline & & & sumatoria & 0.42 & promedio & $2.6 \mathrm{mg} / \mathrm{l}$ \\
\hline \multirow[t]{10}{*}{$\mathrm{Na}$} & nro. amostra & $(\mathrm{mg} / \mathrm{l})$ & xprom. & $(\text { x-xprom })^{\wedge} 2$ & s (desv. Estándar) & significancia ao $95 \%$ \\
\hline & 1 & 7.5 & 7.0375 & 0.214 & 0.311 & se rejeita \\
\hline & 2 & 7.3 & 7.0375 & 0.069 & & se aceita \\
\hline & 3 & 6.8 & 7.0375 & 0.056 & t 0.05 & se aceita \\
\hline & 4 & 6.9 & 7.0375 & 0.019 & 2.92 & se aceita \\
\hline & 5 & 7.3 & 7.0375 & 0.069 & nivel min. & se aceita \\
\hline & 6 & 7.1 & 7.0375 & 0.004 & 6.7 & se aceita \\
\hline & 7 & 6.6 & 7.0375 & 0.191 & nivel max. & se rejeita \\
\hline & 8 & 6.8 & 7.0375 & 0.056 & 7.3 & se aceita \\
\hline & & & sumatoria & 0.68 & promedio & $7.0 \mathrm{mg} / \mathrm{l}$ \\
\hline
\end{tabular}




\section{ANEXO 2}

Tabela 35 Determinação da densidade do rejeito de $\mathrm{Ni}$

\begin{tabular}{|c|c|c|c|c|c|}
\hline \multicolumn{5}{|l|}{ DENSIDADE PARA O REJEITO DE Ni } & \\
\hline & Representação & Resultado 1 & Resultado 2 & Resultado 3 & \\
\hline $\begin{array}{l}\text { Massa do picnômetro } \\
\text { vazio }(\mathrm{g})\end{array}$ & $\mathrm{m}_{\mathrm{PV}}$ & 25.1173 & 25.1342 & 25.1234 & \\
\hline $\begin{array}{l}\text { Massa (picnômetro + } \\
\text { água) (g) }\end{array}$ & $\mathrm{m}_{\mathrm{PH} 2 \mathrm{O}}$ & 51.0472 & 51.0523 & 51.0944 & \\
\hline $\begin{array}{l}\text { Massa (picnômetro + } \\
\text { amostra) (g) }\end{array}$ & $\mathrm{m}_{\mathrm{PA}}$ & 25.901 & 26.0998 & 26.1016 & \\
\hline $\begin{array}{l}\text { Massa (picnômetro + } \\
\text { água + amostra) (g) }\end{array}$ & $\mathbf{m}_{\text {total }}$ & 51.4562 & 51.5725 & 51.5911 & Promedio \\
\hline Densidade dos sólidos $(\mathrm{g} / \mathrm{cm} 3)$ & $d_{s}$ & 2.0915 & 2.1679 & 2.0316 & 2.0970 \\
\hline
\end{tabular}




\section{ANEXO 3}

Tabela 36 Distribuição granulométrica do rejeito de $\mathrm{Ni}$

\begin{tabular}{|c|c|c|c|c|}
\hline \multicolumn{5}{|c|}{ Para o rejelto de NI } \\
\hline \multirow{2}{*}{ Linha } & \multirow{2}{*}{$\begin{array}{c}\text { Abertura } \\
(\mu \mathrm{m})\end{array}$} & \multicolumn{3}{|c|}{ Porcentagem (\%) } \\
\hline & & Retida & Acumulada & Passante \\
\hline 1 & 478.63 & 0.04 & 0.04 & 100.00 \\
\hline 2 & 416.87 & 0.25 & 0.29 & 99.96 \\
\hline 3 & 363.08 & 0.25 & 0.54 & 99.71 \\
\hline 4 & 316.23 & 0.24 & 0.77 & 99.47 \\
\hline 5 & 275.42 & 0.21 & 0.98 & 99.23 \\
\hline 6 & 239.88 & 0.21 & 118 & 99.02 \\
\hline 7 & 208.93 & 0.26 & 144 & 98.82 \\
\hline 8 & 181.97 & 0.35 & 179 & 98.56 \\
\hline 9 & 158.49 & 0.48 & 2.27 & 98.21 \\
\hline 10 & 138.04 & 0.66 & 2.93 & 97.73 \\
\hline 11 & 120.23 & 0.84 & 3.78 & 97.07 \\
\hline 12 & 104.71 & 1.04 & 4.81 & 96.23 \\
\hline 13 & 91.20 & 1.22 & 6.04 & 95.19 \\
\hline 14 & 79.43 & 1.41 & 7.45 & 93.96 \\
\hline 15 & 69.18 & 1.57 & 9.02 & 92.55 \\
\hline 16 & 60.26 & 1.74 & 10.76 & 90.98 \\
\hline 17 & 52.48 & 1.92 & 1268 & 89.24 \\
\hline 18 & 45.71 & 2.12 & 14.80 & 87.32 \\
\hline 19 & 39.81 & 2.35 & 17.15 & 85.20 \\
\hline 20 & 34.67 & 2.58 & 19.73 & 82.85 \\
\hline 21 & 30.20 & 2.84 & 22.57 & 80.27 \\
\hline 22 & 26.30 & 3.10 & 25.66 & 77.43 \\
\hline 23 & 22.91 & 3.35 & 29.02 & 74.34 \\
\hline 24 & 19.95 & 3.59 & 32.61 & 70.98 \\
\hline 25 & 17.38 & 3.80 & 36.40 & 67.39 \\
\hline 26 & 15.14 & 3.96 & 40.36 & 63.60 \\
\hline 27 & 13.18 & 4.09 & 44.46 & 59.64 \\
\hline 28 & 11.48 & 4.17 & 48.62 & 55.54 \\
\hline 29 & 10.00 & 4.21 & 5283 & 5138 \\
\hline 30 & 8.71 & 4.21 & 57.04 & 47.17 \\
\hline 31 & 7.59 & 4.18 & 61.21 & 42.96 \\
\hline 32 & 6.61 & 4.10 & 65.32 & 38.79 \\
\hline 33 & 5.75 & 4.00 & 69.32 & 34.68 \\
\hline 34 & 5.01 & 3.85 & 73.16 & 30.68 \\
\hline 35 & 4.37 & 3.66 & 76.83 & 26.84 \\
\hline 36 & 3.80 & 3.45 & 80.27 & 23.17 \\
\hline 37 & 3.31 & 3.19 & 83.46 & 19.73 \\
\hline 38 & 288 & 2.91 & 86.37 & 16.54 \\
\hline 39 & 2.51 & 2.62 & 89.00 & 13.63 \\
\hline 40 & 219 & 2.34 & 91.33 & 1101 \\
\hline 41 & 1.91 & 2.05 & 93.38 & 8.67 \\
\hline 42 & 166 & 1.78 & 95.16 & 6.62 \\
\hline 43 & 145 & 1.52 & 96.68 & 4.84 \\
\hline 44 & 0.90 & 0.75 & 97.43 & 3.32 \\
\hline 45 & 0.80 & 0.56 & 97.98 & 2.57 \\
\hline 46 & 0.72 & 0.65 & 98.63 & 202 \\
\hline 47 & 0.63 & 0.53 & 99.16 & 137 \\
\hline 48 & 0.55 & 0.40 & 99.56 & 0.84 \\
\hline 49 & 0.48 & 0.28 & 99.84 & 0.44 \\
\hline 50 & 0.42 & 0.15 & 99.99 & 0.16 \\
\hline 51 & 0.36 & 0.01 & 100.00 & 0.01 \\
\hline
\end{tabular}




\section{ANEXO 4}

Tabela 37 Soma dos quadrados dos efeitos para cada tratamento.

\begin{tabular}{|c|c|c|c|c|c|c|c|c|c|}
\hline & Xo & A & B & C & D & E & $A B$ & AC & $A D$ \\
\hline$[\mathrm{X}] \mathrm{T}[\mathrm{Y}]$ & 1575,7 & $-210,1$ & $-507,5$ & 27,1 & 310,9 & 221,1 & 96,7 & 43,5 & $-62,7$ \\
\hline \multirow[t]{2}{*}{ SSXj } & & 1379,4 & 8048,6 & 23,0 & 3020,6 & 1527,7 & 292,2 & 59,1 & 122,9 \\
\hline & $\mathrm{AE}$ & BC & BD & $\mathrm{BE}$ & $C D$ & CE & $\mathrm{DE}$ & $A B C D E$ & \\
\hline$[\mathrm{X}] \mathrm{T}[\mathrm{Y}]$ & 117,3 & $-9,7$ & $-63,9$ & $-34,3$ & $-101,7$ & $-32,3$ & $-132,5$ & 104,5 & \\
\hline SSXj & 430,0 & 2,9 & 127,6 & 36,8 & 323,2 & 32,6 & 548,6 & 341,3 & \\
\hline
\end{tabular}

\section{ANEXO 5}

Tabela 38 Cálculos estatísticos para determinar a análise da variância (Ayres, Torres e Ponce, 2000)

\begin{tabular}{|l|c|c|}
\hline & Equação & Resposta \\
\hline Soma de quadrados do erro & $S S_{\text {erro }}=\sum_{i=1}^{n_{0}}\left(y_{i j}-\overline{\mathrm{y}}\right)^{2}$ & 5,73 \\
\hline Grau de liberdade do erro & $g l E=\left(n_{0}-1\right)$ & 2 \\
\hline $\begin{array}{l}\text { Soma de quadrados da } \\
\text { curvatura }\end{array}$ & $S S_{\text {Curvatura }}=\frac{N \times n_{0}(\overline{\mathrm{Y}}-\overline{\mathrm{y}})}{N+n_{0}}$ & 524,4 \\
\hline $\begin{array}{l}\text { Variância do erro } \\
\text { Variância da soma de } \\
\text { quadrado dos efeitos }\end{array}$ & $M S_{\text {erro }}=\frac{S S_{\text {erro }}}{g l E}$ & 2,86 \\
\hline Teorema de Cochran & $M S S_{X i}=\frac{S S_{X i}}{g l}$ & $\begin{array}{l}\text { De cada teste } \\
(\text { Tabela 11) }\end{array}$ \\
\hline
\end{tabular}




\section{ANEXO 6}

Tabela 39 Matriz codificada do desenho composto central para 5 variáveis

\begin{tabular}{|c|c|c|c|c|c|}
\hline Teste & $\begin{array}{c}\text { Conc. } \\
\text { sólidos }\end{array}$ & Quitosana & AH & Veloc. agit & Tempo agit. \\
\hline $\mathbf{1}$ & $-2,3784$ & 0 & 0 & 0 & 0 \\
\hline $\mathbf{2}$ & 2,3784 & 0 & 0 & 0 & 0 \\
\hline $\mathbf{3}$ & 0 & $-2,3784$ & 0 & 0 & 0 \\
\hline $\mathbf{4}$ & 0 & 2,3784 & 0 & 0 & 0 \\
\hline $\mathbf{5}$ & 0 & 0 & $-2,3784$ & 0 & 0 \\
\hline $\mathbf{6}$ & 0 & 0 & 2,3784 & 0 & 0 \\
\hline $\mathbf{7}$ & 0 & 0 & 0 & $-2,3784$ & 0 \\
\hline $\mathbf{8}$ & 0 & 0 & 0 & 2,3784 & 0 \\
\hline $\mathbf{9}$ & 0 & 0 & 0 & 0 & $-2,3784$ \\
\hline $\mathbf{1 0}$ & 0 & 0 & 0 & 0 & 2,3784 \\
\hline
\end{tabular}

\section{ANEXO 7}

Tabela 40 Determinação do centro e raio do desenho

\begin{tabular}{|l|c|c|c|c|c|}
\cline { 2 - 6 } \multicolumn{1}{c|}{} & A & B & C & D & E \\
\hline Nivel inferior (-) & 1 & 20 & 1,5 & 175 & 1 \\
\hline Nivel superior (+) & 2 & 100 & 5 & 275 & 3 \\
\hline Centro del diseño $\mathbf{Z}^{\circ}$ & 1,5 & 60 & 3,25 & 225 & 2 \\
\hline Radio del diseño $\Delta \mathbf{Z}$ & 0,5 & 40 & 1,75 & 50 & 1 \\
\hline Relacion $\mathbf{E}$ & 3,0 & 1,5 & 1,9 & 4,5 & 2 \\
\hline
\end{tabular}

\section{ANEXO 8}

Tabela 41 Parâmetros codificados para 35 NTU

\begin{tabular}{|c|c|c|c|}
\hline FATOR & Baixo & Alto & Ótimo \\
\hline A & 1 & 2,38 & 1,22 \\
\hline B & $-2,38$ & 0 & $-0,79$ \\
\hline C & 1 & 2,38 & 2,0 \\
\hline D & $-2,38$ & $-2,2$ & $-2,31$ \\
\hline E & -1 & 0 & $-0,37$ \\
\hline
\end{tabular}




\section{ANEXO 9}

Tabela 42 Densidade para a lama vermelha

DENSIDADE PARA A LAMA VERMELHA

\begin{tabular}{|l|l|l|l|}
\hline Representação & Resultado 1 & Resultado 2 & Resultado 3 \\
\hline
\end{tabular}

\begin{tabular}{|c|c|c|c|c|c|}
\hline $\begin{array}{l}\text { Massa do picnômetro } \\
\text { vazio }(\mathrm{g})\end{array}$ & $\mathrm{m}_{\mathrm{PV}}$ & 25.4698 & 25.1519 & 25.4726 & \\
\hline $\begin{array}{l}\text { Massa (picnômetro + } \\
\text { água) (g) }\end{array}$ & $\mathbf{m}_{\mathrm{PH} 2 \mathrm{O}}$ & 52.1016 & 51.0625 & 52.1335 & \\
\hline $\begin{array}{l}\text { Massa (picnômetro + } \\
\text { amostra) (g) }\end{array}$ & $\mathrm{m}_{\mathrm{PA}}$ & 27.1329 & 26.4747 & 26.8043 & \\
\hline $\begin{array}{l}\text { Massa (picnômetro + } \\
\text { água + amostra) (g) }\end{array}$ & $\mathbf{m}_{\text {total }}$ & 52.9285 & 51.7339 & 52.7274 & Promedio \\
\hline Densidade dos sólidos $(\mathrm{g} / \mathrm{cm} 3)$ & $d_{s}$ & 1.9889 & 2.0307 & 1.8050 & 1.9415 \\
\hline
\end{tabular}




\section{ANEXO 10}

Tabela 43 Distribuição granulométrica da lama vermelha

\begin{tabular}{|c|c|c|c|c|}
\hline \multicolumn{5}{|c|}{ Para a lama vermelha } \\
\hline \multirow{2}{*}{ Linha } & \multirow{2}{*}{$\begin{array}{c}\begin{array}{c}\text { Abertura } \\
(\mu \mathrm{m})\end{array} \\
\end{array}$} & \multicolumn{3}{|c|}{ Porcentagem (96) } \\
\hline & & Retida & Acumulada & Passante \\
\hline 1 & 549.54 & 0.02 & 0.02 & 100.00 \\
\hline 2 & 478.63 & 0.09 & 0.11 & 99.98 \\
\hline 3 & 416.87 & 0.11 & 0.21 & 99.89 \\
\hline 4 & 363.08 & 0.11 & 0.32 & 99.79 \\
\hline 5 & 316.23 & 0.10 & 0.42 & 99.68 \\
\hline 6 & 275.42 & 0.09 & 0.50 & 99.58 \\
\hline 7 & 239.88 & 0.08 & 0.58 & 99.50 \\
\hline 8 & 208.93 & 0.10 & 0.68 & 99.42 \\
\hline 9 & 181.97 & 0.15 & 0.83 & 99.32 \\
\hline 10 & 158.49 & 0.23 & 1.05 & 99.17 \\
\hline 11 & 138.04 & 0.31 & 1.36 & 98.95 \\
\hline 12 & 120.23 & 0.40 & 1.76 & 98.64 \\
\hline 13 & 104.71 & 0.48 & 2.24 & 98.24 \\
\hline 14 & 91.20 & 0.57 & 2.81 & 97.76 \\
\hline 15 & 79.43 & 0.64 & 3.46 & 97.19 \\
\hline 16 & 69.18 & 0.72 & 4.17 & 96.54 \\
\hline 17 & 60.26 & 0.85 & 5.02 & 95.83 \\
\hline 18 & 52.48 & 0.90 & 5.92 & 94.98 \\
\hline 19 & 45.71 & 1.02 & 6.94 & 94.08 \\
\hline 20 & 39.81 & 1.20 & 8.15 & 93.06 \\
\hline 21 & 34.67 & 1.44 & 9.59 & 91.85 \\
\hline 22 & 30.20 & 1.73 & 11.32 & 90.41 \\
\hline 23 & 26.30 & 2.06 & 13.38 & 88.68 \\
\hline 24 & 22.91 & 2.43 & 15.80 & 86.62 \\
\hline 25 & 19.95 & 2.80 & 18.61 & 84.20 \\
\hline 26 & 17.38 & 3.19 & 21.80 & 81.39 \\
\hline 27 & 15.14 & 3.54 & 25.34 & 78.20 \\
\hline 28 & 13.18 & 3.87 & 29.21 & 74.66 \\
\hline 29 & 11.48 & 4.15 & 33.35 & 70.79 \\
\hline 30 & 10.00 & 4.37 & 37.72 & 66.65 \\
\hline 31 & 8.71 & 4.51 & 42.23 & 62.28 \\
\hline 32 & 7.59 & 4.59 & 46.82 & 57.77 \\
\hline 33 & 6.61 & 4.59 & 51.40 & 53.18 \\
\hline 34 & 5.75 & 4.50 & 55.90 & 48.60 \\
\hline 35 & 5.01 & 4.36 & 60.26 & 44.10 \\
\hline 36 & 4.37 & 4.18 & 64.44 & 39.74 \\
\hline 37 & 3.80 & 3.97 & 68.41 & 35.56 \\
\hline 38 & 3.31 & 3.77 & 72.18 & 31.59 \\
\hline 39 & 2.88 & 3.59 & 75.76 & 27.82 \\
\hline 40 & 2.51 & 3.42 & 79.18 & 24.24 \\
\hline 41 & 2.19 & 3.26 & 82.44 & 20.82 \\
\hline 42 & 1.91 & 3.11 & 85.56 & 17.56 \\
\hline 43 & 1.66 & 2.96 & 88.52 & 14.44 \\
\hline 44 & 1.45 & 2.79 & 91.31 & 11.48 \\
\hline 45 & 0.90 & 1.82 & 93.13 & 8.69 \\
\hline 46 & 0.72 & 1.75 & 94.88 & 6.87 \\
\hline 47 & 0.63 & 1.49 & 96.37 & 5.12 \\
\hline 48 & 0.55 & 1.24 & 97.61 & 3.63 \\
\hline 49 & 0.48 & 0.97 & 98.57 & 2.39 \\
\hline 50 & 0.42 & 0.71 & 99.28 & 1.43 \\
\hline 51 & 0.36 & 0.47 & 99.75 & 0.72 \\
\hline 52 & 0.32 & 0.22 & 99.97 & 0.25 \\
\hline 53 & 0.28 & 0.03 & 100.00 & 0.032 \\
\hline
\end{tabular}




\section{ANEXO 11}

Tabela 44 Soma dos quadrados dos efeitos para cada tratamento.

\begin{tabular}{|c|c|c|c|c|c|c|c|c|c|}
\hline & Xo & A & B & C & D & E & $A B$ & AC & AD \\
\hline$[\mathrm{X}] \mathrm{T}[\mathrm{Y}]$ & 1786,7 & 408,3 & $-551,8$ & $-8,4$ & 210,0 & 103,0 & $-24,2$ & $-14,1$ & 134,4 \\
\hline Efecto $\Delta / 2$ & 55,83 & 12,76 & $-17,24$ & $-0,26$ & 6,56 & 3,22 & $-0,75$ & $-0,44$ & 4,20 \\
\hline & $\mathrm{AE}$ & BC & BD & BE & $C D$ & CE & DE & ABCDE & \\
\hline$[\mathrm{X}] \mathrm{T}[\mathrm{Y}]$ & $-8,4$ & 210,0 & 103,0 & $-24,2$ & $-14,1$ & 134,4 & 189,0 & 30,7 & \\
\hline Efecto $\Delta / 2$ & $-0,26$ & 6,56 & 3,22 & $-0,75$ & $-0,44$ & 4,20 & 5,90 & 0,96 & \\
\hline
\end{tabular}

\section{ANEXO 12}

Tabela 45 Cálculos estatísticos para determinar a análise da variância

\begin{tabular}{|l|c|c|}
\hline Soma de quadrados do erro & \multicolumn{1}{|c|}{ Equação } & Resposta \\
\hline $\begin{array}{l}\text { Grau de liberdade do erro } \\
\text { erro }\end{array} \sum_{i=1}^{n_{0}}\left(y_{i j}-\overline{\mathrm{Y}}\right)^{2}$ & 1,39 \\
\hline $\begin{array}{l}\text { Soma de quadrados da } \\
\text { curvatura }\end{array}$ & $g l E=\left(n_{0}-1\right)$ & 2 \\
\hline $\begin{array}{l}\text { Variância do erro } \\
\text { Variância da soma de } \\
\text { quadrado dos efeitos }\end{array}$ & $M S_{\text {Curvatura }}=\frac{N \times n_{0}(\overline{\mathrm{Y}}-\overline{\mathrm{Y}})}{N+n_{0}}$ & 50,64 \\
\hline Teorema de Cochran & $M S S_{X i}=\frac{S S_{X i}}{g l}$ & 0,69 \\
& $F_{0}=\frac{M S S_{x j}}{M S_{\text {erro }}}$ & $\begin{array}{l}\text { De cada teste } \\
\text { (Tabela 24) }\end{array}$ \\
\hline
\end{tabular}




\section{ANEXO 13}

Tabela 46 Análise de residuos

\begin{tabular}{|r|r|c|c|c|}
\hline $\mathbf{N}$ & \multicolumn{1}{|c|}{$\mathbf{Y}$} & $\hat{\mathbf{Y}}$ & $\mathbf{( \mathbf { Y } - \hat { \mathbf { Y } } )}$ & $(\mathbf{Y}-\hat{\mathbf{Y}})^{\wedge} \mathbf{2}$ \\
\hline 1 & 58 & 68,9 & $-10,88$ & 118,37 \\
\hline 2 & 83 & 74,2 & 8,82 & 77,79 \\
\hline 3 & 24,7 & 21,6 & 3,06 & 9,36 \\
\hline 4 & 27,8 & 26,9 & 0,81 & 0,66 \\
\hline 5 & 66,6 & 65,2 & 1,44 & 2,07 \\
\hline 6 & 69,4 & 70,5 & $-1,06$ & 1,12 \\
\hline 7 & 21,8 & 17,9 & 3,88 & 15,05 \\
\hline 8 & 27,4 & 23,2 & 4,18 & 17,47 \\
\hline 9 & 75,6 & 73,6 & 2,02 & 4,08 \\
\hline 10 & 102 & 95,7 & 6,28 & 39,44 \\
\hline 11 & 25,6 & 26,3 & $-0,74$ & 0,55 \\
\hline 12 & 41,3 & 48,5 & $-7,18$ & 51,55 \\
\hline 13 & 68,9 & 69,9 & $-0,96$ & 0,92 \\
\hline 14 & 86,4 & 92 & $-5,6$ & 31,36 \\
\hline 15 & 24,9 & 22,6 & 2,28 & 5,20 \\
\hline 16 & 38,5 & 44,8 & $-6,26$ & 39,19 \\
\hline 17 & 58 & 47 & 10,96 & 120,12 \\
\hline 18 & 74,8 & 75,9 & $-1,14$ & 1,30 \\
\hline 19 & 23,8 & 25,3 & $-1,52$ & 2,31 \\
\hline 20 & 49 & 54,2 & $-5,22$ & 27,25 \\
\hline 21 & 47,2 & 50,8 & $-3,56$ & 12,67 \\
\hline 22 & 71 & 79,7 & $-8,66$ & 75,00 \\
\hline 23 & 25,6 & 29 & $-3,44$ & 11,83 \\
\hline 24 & 60,3 & 57,9 & 2,36 & 5,57 \\
\hline 25 & 46,9 & 51,7 & $-4,84$ & 23,43 \\
\hline 26 & 96,1 & 97,5 & $-1,38$ & 1,90 \\
\hline 27 & 30,6 & 30 & 0,58 & 0,34 \\
\hline 28 & 80,4 & 75,8 & 4,64 & 21,53 \\
\hline 29 & 55,3 & 55,5 & $-0,16$ & 0,03 \\
\hline 30 & 110 & 101 & 8,8 & 77,44 \\
\hline 31 & 35,7 & 33,7 & 1,96 & 3,84 \\
\hline 32 & 80,1 & 79,5 & 0,62 & 0,38 \\
\hline & & & sumatoria & 799,14 \\
\hline
\end{tabular}




\section{ANEXO 14}

Tabela 47 Determinação do centro e raio do desenho

\begin{tabular}{|l|c|c|c|c|c|}
\cline { 2 - 6 } \multicolumn{1}{c|}{} & A & B & C & D & E \\
\hline Nivel inferior (-) & 0,5 & 650 & 8 & 175 & 1 \\
\hline Nivel superior (+) & 1 & 1300 & 16 & 275 & 3 \\
\hline Centro del diseño $\mathbf{Z}^{\circ}$ & 0,75 & 975 & 12 & 225 & 2 \\
\hline Radio del diseño $\Delta \mathbf{Z}$ & 0,25 & 325 & 4 & 50 & 1 \\
\hline Relacion E & 3 & 3 & 3 & 4,5 & 2 \\
\hline
\end{tabular}

\section{ANEXO 15}

Tabela 48 Soma dos quadrados dos efeitos para cada tratamento.

\begin{tabular}{|c|c|c|c|c|c|c|c|c|}
\hline & Xo & A & B & C & AB & AC & BC & ABC \\
\hline$[\mathbf{X}]$ T[Y] & 360,28 & 227,23 & $-188,63$ & $-98,18$ & $-148,28$ & $-103,93$ & 110,33 & 95,18 \\
\hline Efecto $\boldsymbol{\Delta} / \mathbf{2}$ & 45,03 & 28,40 & $-23,58$ & $-12,27$ & $-18,53$ & $-12,99$ & 13,79 & 11,90 \\
\hline
\end{tabular}

\section{ANEXO 16}

Tabela 49 Cálculos estadísticos para determinar a análise da variância

\begin{tabular}{|l|c|c|}
\hline & Equação & Resposta \\
\hline Soma de quadrados do erro & $S S_{\text {erro }}=\sum_{i=1}^{n_{0}}\left(y_{i j}-\overline{\mathrm{y}}\right)^{2}$ & 1,45 \\
\hline Grau de liberdade do erro & $g l E=\left(n_{0}-1\right)$ & 2 \\
\hline $\begin{array}{l}\text { Soma de quadrados da } \\
\text { curvatura }\end{array}$ & $S S_{\text {Curvatura }}=\frac{N \times n_{0}(\overline{\mathrm{Y}}-\overline{\mathrm{y}})}{N+n_{0}}$ & 442,01 \\
\hline $\begin{array}{l}\text { Variância do erro } \\
\text { Variância da soma de } \\
\text { quadrado dos efeitos }\end{array}$ & $M S_{\text {erro }}=\frac{S S_{\text {erro }}}{g l E}$ & 0,72 \\
\hline Teorema de Cochran & $M S S_{X i}=\frac{S S_{X i}}{g l}$ & $\begin{array}{l}\text { De cada teste } \\
(\text { Tabela 35) }\end{array}$ \\
\hline
\end{tabular}




\section{ANEXO 17}

Tabela 50 Matriz codificada do desenho composto central para 3 variáveis

\begin{tabular}{|c|c|c|c|}
\hline Teste & Conç. Sólidos & Quitosana & AH \\
\hline $\mathbf{1}$ & $-1,6818$ & 0 & 0 \\
\hline $\mathbf{2}$ & 1,6818 & 0 & 0 \\
\hline $\mathbf{3}$ & 0 & $-1,6818$ & 0 \\
\hline $\mathbf{4}$ & 0 & 1,6818 & 0 \\
\hline $\mathbf{5}$ & 0 & 0 & $-1,6818$ \\
\hline $\mathbf{6}$ & 0 & 0 & 1,6818 \\
\hline
\end{tabular}

\section{ANEXO 18}

Tabela 51 Parâmetros codificados para 35 NTU

\begin{tabular}{|c|c|c|c|}
\hline Fator & Baixo & Alto & Ótimo \\
\hline Conc. sólidos & 0 & 1,682 & 0,009 \\
\hline Quitosana & 0 & 1,682 & 1,102 \\
\hline AH & 0 & 0,003 & 0,002 \\
\hline
\end{tabular}




\section{ANEXO 19}

Tabela 52 Pontos de percentagem de distribuição F: pontos superiores a 1\% (Ayres, Torres e Ponce, 2000)

Tabela 7. Limites unilaterais da distribuição $\mathrm{F}$ de Fisher-Snedecor ao nivel de $1,0 \%$ de probabilidade.

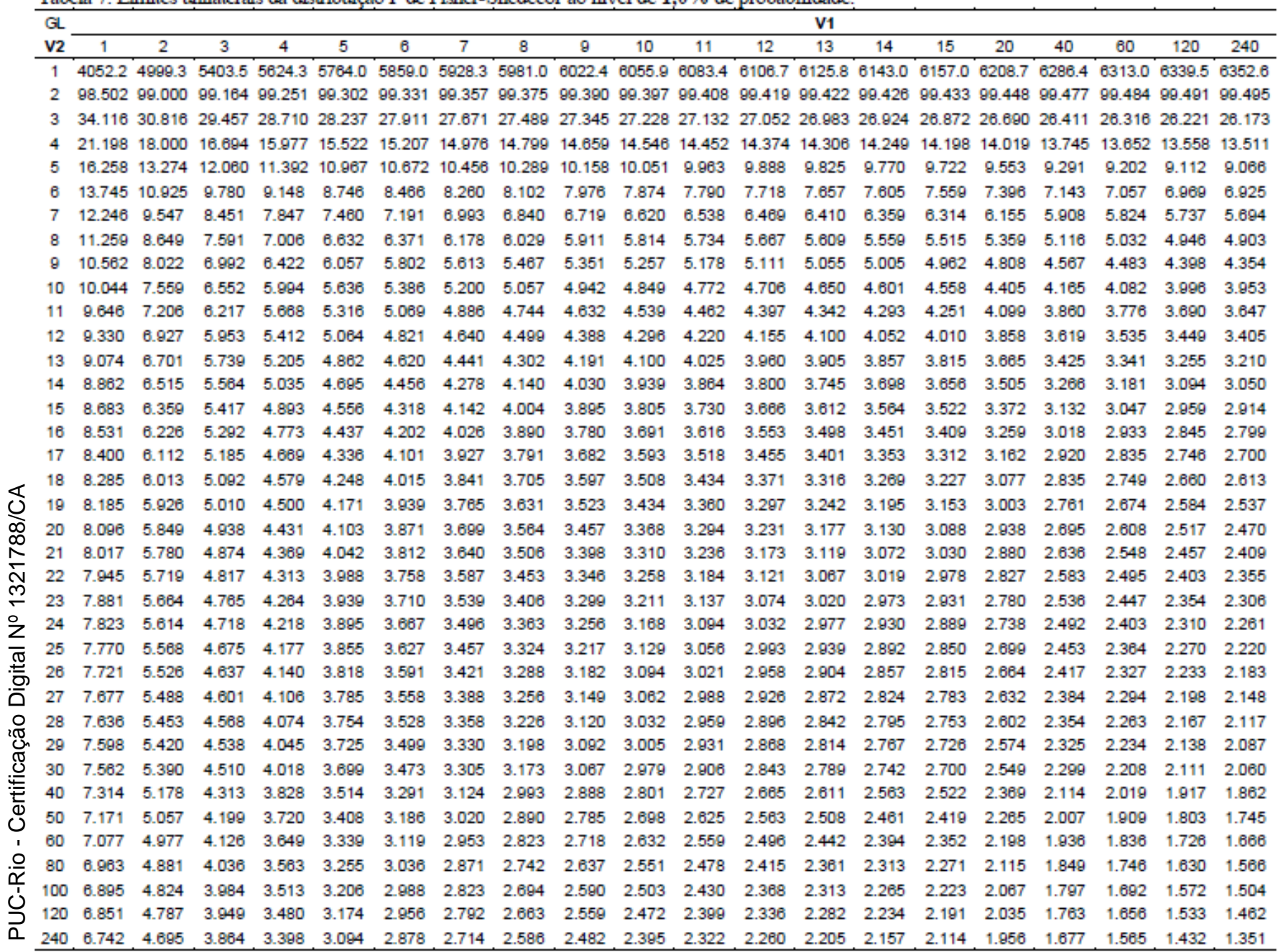

